\title{
CHARACTERIZATION AND ACTUAL WASTE TESTS WITH TANK 5F SAMPLES
}

August 30, 2007

Waste Processing Technology Section Savannah River National Laboratory Aiken, SC 29808

Prepared for the U.S. Department of Energy Under Contract Number DEAC09-96SR18500

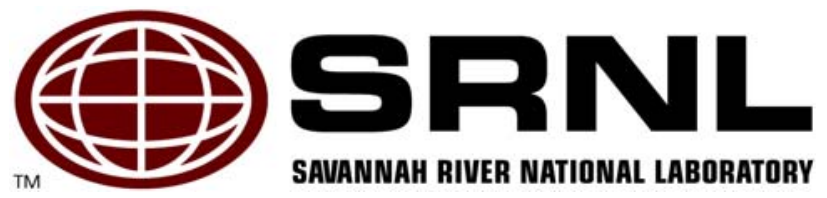




\section{DISCLAIMER}

This report was prepared for the United States Department of Energy under Contract No. DE-AC09-96SR18500 and is an account of work performed under that contract. Neither the United States Department of Energy, nor WSRC, nor any of their employees makes any warranty, expressed or implied, or assumes any legal liability or responsibility for the accuracy, completeness, or usefulness, of any information, apparatus, or product or process disclosed herein or represents that its use will not infringe privately owned rights. Reference herein to any specific commercial product, process, or service by trade name, trademark, name, manufacturer or otherwise does not necessarily constitute or imply endorsement, recommendation, or favoring of same by Washington Savannah River Company or by the United States Government or any agency thereof. The views and opinions of the authors expressed herein do not necessarily state or reflect those of the United States Government or any agency thereof.

\section{Printed in the United States of America}

Prepared For

U.S. Department of Energy 
Key Words:

Sludge Analysis

Supernate Analysis

Salt Analysis

\section{Retention: Permanent}

Key References:

Technical Task Request: HLE-TTR-2006-009

Task Plan: WSRC-RP-2006-00717, Rev. 0

Analytical Study Plan: SRNL-CST-2006-00085

\section{CHARACTERIZATION AND ACTUAL WASTE TESTS WITH TANK 5F SAMPLES}

M. S. Hay, SRNL/A\&CPT

K. P. Crapse, SRNL/A\&CPT

S. D. Fink, SRNL/A\&CPT

J. M. Pareizs, SRNL/PS\&E

Issue Date: August 30, 2007

Waste Processing Technology Section Savannah River National Laboratory Aiken, SC 29808

Prepared for the U.S. Department of Energy Under Contract Number DEAC09-96SR18500

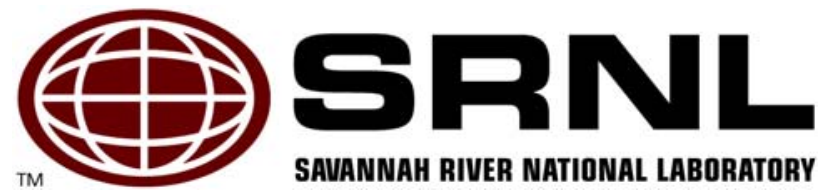




\section{REVIEWS AND APPROVALS}

M. S. Hay, Author, SRNL/A\&CPT

Date

K. P. Crapse, Author, SRNL/A\&CPT

Date

J. M. Pareizs, Author, SRNL/PS\&E

Date

C. J. Martino, Technical Reviewer, SRNL/A\&CPT

Date

S. D. Fink, SRNL/SSP, Manager

Date

J. C. Griffin, SRNL/CS\&T, Manager

Date

N. F. Chapman, Tank Closure and Technology Development

Date

G. D. Thaxton, IV, Design Authority Lead, Tanks 5 \& 6 Chemical Heel Removal Date 


\section{TABLE OF CONTENTS}

List of Tables $\quad$ iv

\begin{tabular}{ll|l} 
List of Figures & v
\end{tabular}

List of Acronyms vii

SUMMARY viii

$\begin{array}{ll}1.0 \text { INTRODUCTION } & 1\end{array}$

$\begin{array}{ll}2.0 \text { SAMPLE DESCRIPTION AND PREPARATION } & 2\end{array}$

2.1 SAMPLE DESCRIPTION

2.2 SUPERNATE SAMPLE PREPARATION FOR ANALYSIS $\quad 3$

2.3 SLUDGE SAMPLE PREPARATION FOR ANALYSIS 4

2.4 SNAPPER SAMPLE (WHITE SOLIDS) PREPARATION FOR ANALYSIS $\quad 5$

2.5 TANK CLEANING TEST SAMPLE PREPARATION $\quad 6$

\subsection{RESULTS OF THE SAMPLE CHARACTERIZATION 8}

3.1 GENERAL INFORMATION $\quad 8$

3.2 RESULTS OF THE ANALYSIS OF THE TANK 7F SUPERNATE SAMPLE

3.3 RESULTS OF THE ANALYSIS OF THE TANK 5F SLUDGE SAMPLE 9

3.4 RESULTS OF THE ANALYSIS OF THE TANK 5F SNAPPER (WHITE SOLIDS) SAMPLE 10

3.5 RESULTS OF THE ANALYSIS OF THE TANK 5F SIMULATED TANK CLEANING TEST SAMPLES 11

\subsection{DISCUSSION OF RESULTS}

4.1 TANK 5F SLUDGE SAMPLE CHARACTERIZATION $\quad 70$

4.2 TANK 5F SALT SAMPLE CHARACTERIZATION

4.3 SLUDGE DISSOLUTION IN THE SIMULATED OXALIC ACID CLEANING TESTS 71

4.4 DISCUSSION OF RESULTS FROM NEUTRALIZATION OF THE OXALIC ACID FILTRATE

4.5 DISCUSSION OF THE FATE OF PLUTONIUM AND URANIUM IN THE SIMULATED TANK CLEANING TESTS 74

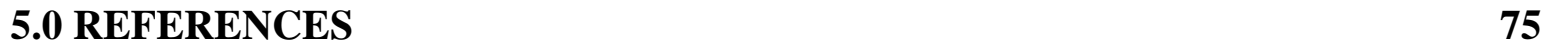




\section{List of Tables}

TABLE 2-1. COMPOSITION OF THE ANALYTICAL REFERENCE GLASS-1 STANDARD. ..........................................

TABLE 2-2. MEASURED COMPOSITION OF THE SiMULATED TANK 7F SUPERNATE..............................................

TABLE 3-1. ABBREVIATIONS FOR ANAL YTICAL METHODS USED IN DATA TABLES ...........................................8

TABLE 3-2. COMPOSITION OF THE SUPERNATE DiP SAMPLE FTF-07-06-19 FROM TANK 7F.............................13

TABle 3-3. Composition of The Aqua Regia DisSOlution of Solids From TANK 5F Sludge Sample FTF-05-06-55 ...................................................................................................................14

TABle 3-4. COMPOSITION OF THE SODIUM PEROXIDE Fusion DisSOLUTION OF SOLIDS FROM TANK 5F

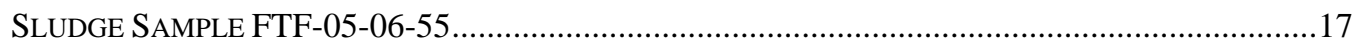

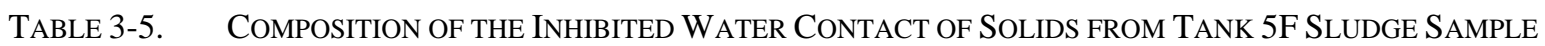

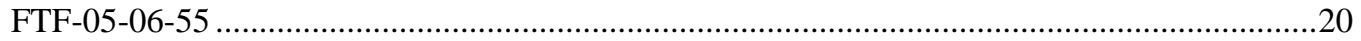

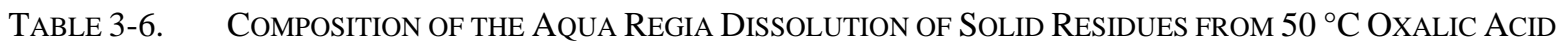

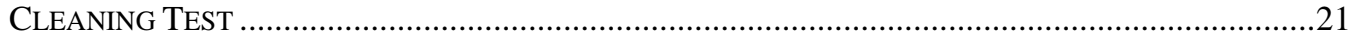

TABle 3-7. COMPOSITION OF THE Aqua Regia DisSOlution of SOlid ReSidues FROM $75^{\circ} \mathrm{C}$ OXALIC ACID

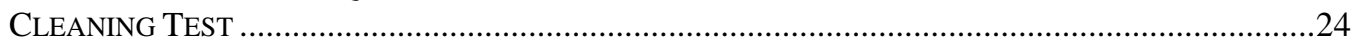

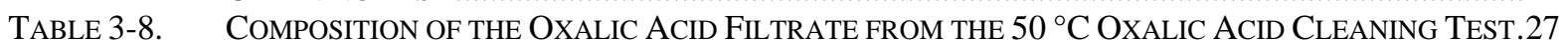

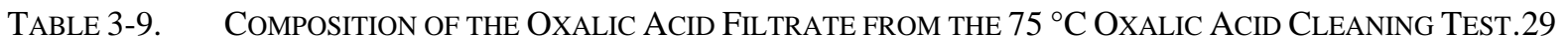

Table 3-10. Composition of the Aqua Regia Dissolution of Solid Residues From $50^{\circ} \mathrm{C}$ NEUTRALIZATION TEST.

Table 3-11. Composition of the Aqua Regia Dissolution of Solid Residues From $75^{\circ} \mathrm{C}$

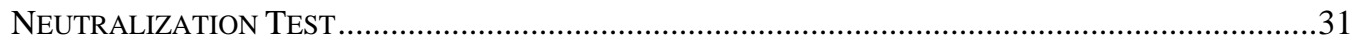

TABLE 3-12. COMPOSITION OF THE FILTRATE FROM THE $50^{\circ} \mathrm{C}$ NEUTRALIZATION TEST ......................................32

TABLE 3-13. COMPOSITION OF THE FILTRATE FROM THE $75^{\circ} \mathrm{C}$ NEUTRALIZATION TEST ...................................34

TABLE 4-1. SUMMARY OF TANK 5F SLUDGE COMPOSITION ……..................................................................70

TAble 4-2. Estimated Percentage of Key Elements Dissolved From the TANK 5F SLUdge DURING

TANK CLEANING TESTS BASED ON OXALIC ACID ANALYSIS .........................................................72

TABle 4-3. Estimated Percentage OF Key Elements Dissolved From the TANK 5F SLUdge duRING TANK CLEANING TESTS BASED ON THE SOLIDS ANALYSIS .........................................................72 


\section{List of Figures}

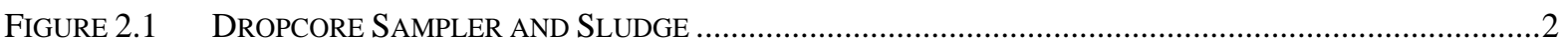

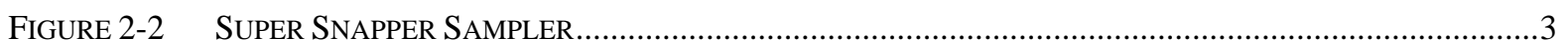

FIGURE 2-3 WHITE SOLIDS (COATED WITH SLUDGE) ISOLATED FROM THE SAMPLE ..........................................6

Figure 3.1 X-RAY DifFRACTION FOR White SOLIDS FROM TANK 5F SAMPLE FTF-05-07-1, REPLICATE 1...36

Figure 3.2 X-RAY DifFRACTION FOR White SOLIDS FROM TANK 5F SAMPLE FTF-05-07-1, REPLiCATE 2 ...36

Figure 3.3 X-RAY DifFraction FOR White SOLIDS FROM TANK 5F SAMPLE FTF-05-07-1, REPLICATE 3 ...37

Figure 3.4 SEM MicROGRAPH OF SOLIDS FROM TANK 5F SLUdGE SAMPLE (18X MAGNIFICATION) .............38

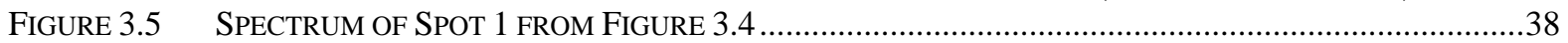

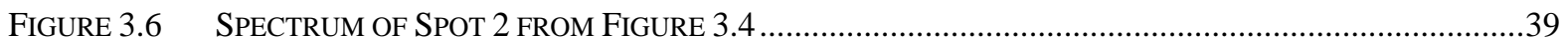

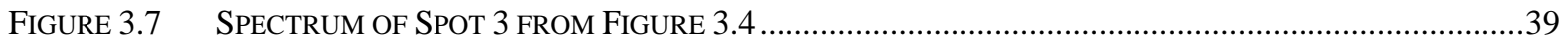

FIGURE 3.8 SPECTRUM OF SPOT 4 FROM FIGURE 3.4 …..........................................................................40

FIGURE 3.9 SPECTRUM OF SPOT 5 FROM FIGURE 3.4 ………...................................................................40

FiguRE 3.10 SEM MicROGRAPH OF SOLIDS FROM TANK 5F SLUDGE SAMPLE (250X MAGNIFICATION) ......41

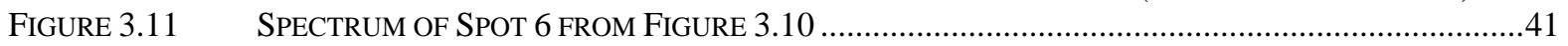

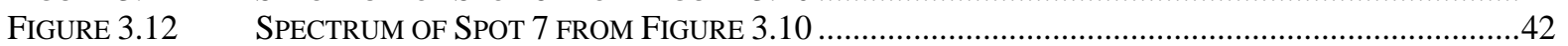

Figure 3.13 SEM Micrograph OF SOLIDS FROM TANK 5F SLUdGE SAMPLE (40X MAGNIFICATION) ........42

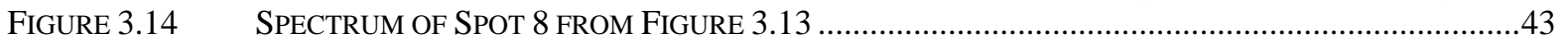

FIGURE 3.15 SPECTRUM OF SPOT 9 FROM FIGURE 3.13 ……..................................................................4

FigurE 3.16 SEM MicROGRAPH OF SOLIDS FROM TANK 5F SALT SAMPLE (15X MAGNIFICATION) ..............44

FIGURE 3.17 SPECTRUM OF SPOT 1 FROM FIGURE 3.16 ........................................................................

FIGURE 3.18 SPECTRUM OF SPOT 2 FROM FIGURE 3.16 ......................................................................4

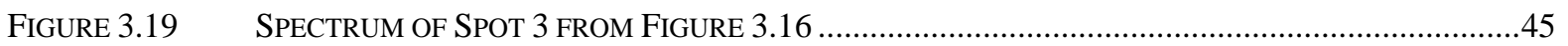

FIGURE $3.20 \quad$ SPECTRUM OF SPOT 4 FROM FIGURE 3.16 ...........................................................................46

FIGURE 3.21 SPECTRUM OF SPOT 5 FROM FIGURE 3.16 ....................................................................46

FiguRE 3.22 SEM MicROGRAPH OF SOLIDS FROM TANK 5F SALT SAMPLE (18X MAGNIFICATION) .............47

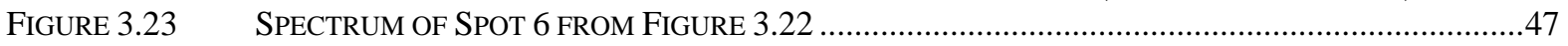

FiguRE 3.24 SEM MiCROGRAPH OF SOLIDS FROM $50{ }^{\circ} \mathrm{C}$ OXALIC ACID TEST (18X MAGNIFICATION) ..........48

FIGURE 3.25 SPECTRUM OF SPOT 1 FROM FIGURE 3.24 ..............................................................................48

FigurE 3.26 SEM MiCROGRAPH OF SOLIDS FROM $50^{\circ} \mathrm{C}$ OXALIC ACID TEST (158X MAGNIFICATION) ........49

FIGURE 3.27 SPECTRUM OF SPOT 2 FROM FIGURE 3.26 ..........................................................................49

FIGURE 3.28 SPECTRUM OF SPOT 3 FROM FIGURE 3.26 .........................................................................50

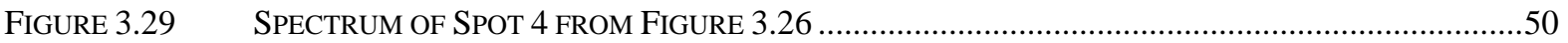

Figure 3.30 SEM MiCROGRAPH OF SOLIDS FROM $50^{\circ} \mathrm{C}$ OXALIC ACID TEST (233X MAGNIFICATION) ........51

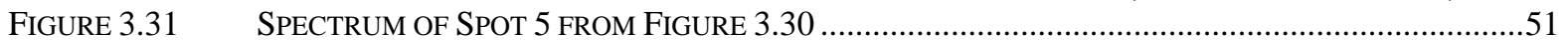

Figure 3.32 SEM MiCROGRAPH OF SOLIDS FROM $50^{\circ} \mathrm{C}$ OXALIC ACID TEST (512X MAGNIFICATION) ........52

FIGURE 3.33 SPECTRUM OF SPOT 6 FROM FIGURE 3.32 ...........................................................................52

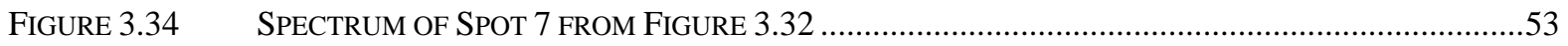

FiguRE 3.35 SEM MiCROGRAPH OF SOLIDS FROM $75^{\circ} \mathrm{C}$ OXALIC ACID TEST (18X MAGNIFICATION) ...........54

FIGURE 3.36 SPECTRUM OF SPOT 1 FROM FIGURE 3.35 ….....................................................................54

Figure 3.37 SEM MiCROGRAPH OF SOLIDS FROM $75^{\circ} \mathrm{C}$ OXALIC ACID TEST (118X MAGNIFICATION) ........55

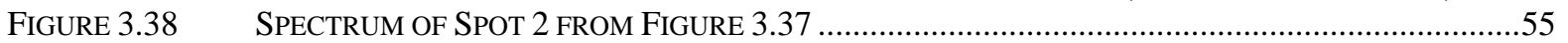

FIGURE 3.39 SPECTRUM OF SPOT 3 FROM FIGURE 3.37 ..........................................................................56

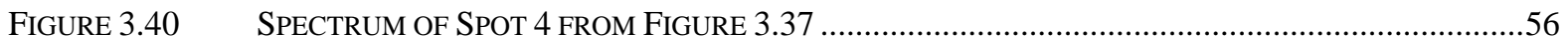

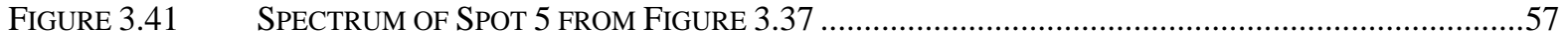

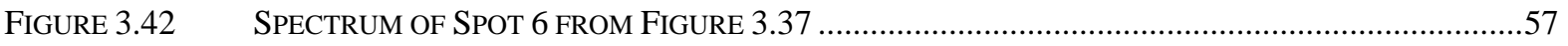

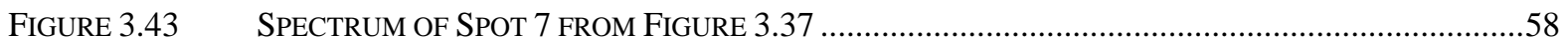

FigURE 3.44 SEM MiCROGRAPH OF SOLIDS FROM $75^{\circ} \mathrm{C}$ OXALIC ACID TEST (215X MAGNIFICATION) ........58

FIGURE 3.45 SPECTRUM OF SPOT 8 FROM FIGURE 3.44 ……................................................................59

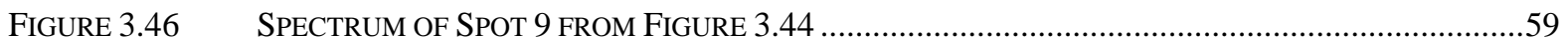

FIGURE 3.47 SPECTRUM OF SPOT 10 FROM FIGURE 3.44 …........................................................................60

FIGURE 3.48 SPECTRUM OF SPOT 11 FROM FIGURE 3.44 ……..............................................................60

Figure 3.49 SEM MiCROGRAPH OF SOLIDS FROM $50^{\circ} \mathrm{C}$ NEUTRALIZATION TEST (18X MAGNIFICATION) ..61 
WSRC-STI-2007-00192, REV. 1

FIGURE 3.50

FIGURE 3.51

FIGURE 3.52

FIGURE 3.53

FIGURE 3.54

FIGURE 3.55

FIGURE 3.56

FIGURE 3.57

FIGURE 3.58

FIGURE 3.59

FIGURE 3.60

FIGURE 3.61

FIGURE 3.62

FIGURE 3.63

FIGURE 3.64
SPECTRUM OF SPOT 1 FROM FIGURE 3.49 .61 SEM MiCROGRAPH OF SOLIDS FROM $50^{\circ} \mathrm{C}$ NEUTRALIZATION TEST (100X MAGNIFICATION) 62

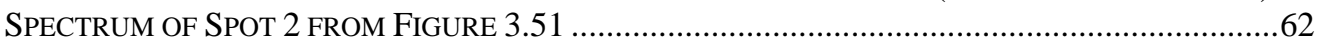
SPECTRUM OF SPOT 3 FROM FIGURE 3.51 .......................................................................63 SEM MiCROGRAPH OF SOLIDS FROM $50^{\circ} \mathrm{C}$ NEUTRALIZATION TEST (500X MAGNIFICATION) 64 SPECTRUM OF SPOT 4 FROM FIGURE 3.54 64 SEM MiCROGRAPH OF SOLIDS FROM $50^{\circ} \mathrm{C}$ NEUTRALIZATION TEST (431X MAGNIFICATION) 65

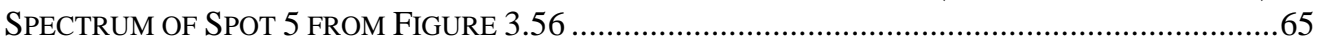
SEM MiCROGRAPH OF SOLIDS FROM $75^{\circ} \mathrm{C}$ NEUTRALIZATION TEST (15X MAGNIFICATION) ..66

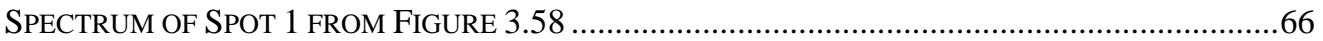

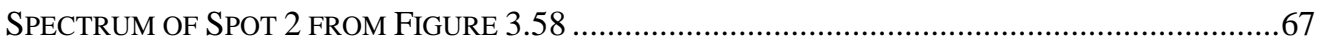
SEM MiCROGRAPH OF SOLIDS FROM $75^{\circ} \mathrm{C}$ NEUTRALIZATION TEST (100X MAGNIFICATION) 67

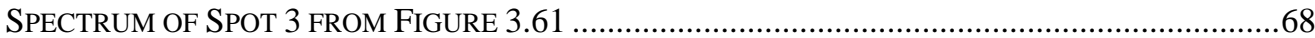

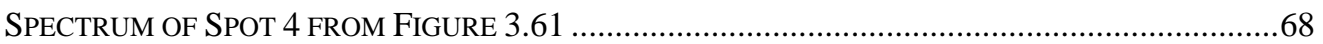
SEM MICROGRAPH OF SOLIDS FROM $75^{\circ} \mathrm{C}$ NEUTRALIZATION TEST (500X MAGNIFICATION) 69 


\section{List of Acronyms}

$\begin{array}{ll}\text { AD } & \text { Analytical Development } \\ \text { ARG1 } & \text { Analytical Reference Glass 1 } \\ \text { CSEM } & \text { Contained Scanning Electron Microscopy } \\ \text { EDX } & \text { Energy Dispersive X-ray } \\ \text { IC } & \text { Ion Chromatography } \\ \text { ICP-ES } & \text { Inductively Couple Plasma-Emission Spectroscopy } \\ \text { ICP-MS } & \text { Inductively Couple Plasma-Mass Spectrometry } \\ \text { SRNL } & \text { Savannah River National Laboratory } \\ \text { TIC } & \text { Total Inorganic Carbon } \\ \text { TTR } & \text { Technical Task Request } \\ \text { XRD } & \text { X-ray Diffraction } \\ \text { \%RSD } & \text { Percent Relative Standard Deviation }\end{array}$




\section{SUMMARY}

The initial phase of bulk waste removal operations was recently completed in Tank 5F. Video inspection of the tank indicates several mounds of sludge still remain in the tank. Additionally, a mound of white solids was observed under Riser 5. In support of chemical cleaning and heel removal programs, samples of the sludge and the mound of white solids were obtained from the tank for characterization and testing. A core sample of the sludge and Super Snapper sample of the white solids were characterized. A supernate dip sample from Tank 7F was also characterized. A portion of the sludge was used in two tank cleaning tests using oxalic acid at $50{ }^{\circ} \mathrm{C}$ and $75^{\circ} \mathrm{C}$. The filtered oxalic acid from the tank cleaning tests was subsequently neutralized by addition to a simulated Tank $7 \mathrm{~F}$ supernate. Solids and liquid samples from the tank cleaning test and neutralization test were characterized. A separate report documents the results of the gas generation from the tank cleaning test using oxalic acid and Tank 5F sludge. ${ }^{2}$

The characterization results for the Tank 5F sludge sample (FTF-05-06-55) appear quite good with respect to the tight precision of the sample replicates, good results for the glass standards, and minimal contamination found in the blanks and glass standards. The aqua regia and sodium peroxide fusion data also show good agreement between the two dissolution methods. Iron dominates the sludge composition with other major contributors being uranium, manganese, nickel, sodium, aluminum, and silicon. The low sodium value for the sludge reflects the absence of supernate present in the sample due to the core sampler employed for obtaining the sample.

The XRD and CSEM results for the Super Snapper salt sample (i.e., white solids) from Tank 5F (FTF-05-07-1) indicate the material contains hydrated sodium carbonate and bicarbonate salts along with some aluminum hydroxide. These compounds likely precipitated from the supernate in the tank. A solubility test showed the material to be water-soluble consistent with the determined composition.

The analytical data for the solid residues filtered from the oxalic acid solution and filtered oxalic acid indicate a large portion of the Tank 5F sludge used in the tank cleaning test dissolved into the oxalic acid. The results of a material balance calculation indicate a high percentage of the iron, uranium, sodium, and aluminum dissolved during both tests. Approximately half of the manganese, a small portion of the plutonium, and essentially none of the nickel dissolved during the tank cleaning tests. Additionally, the results show slightly higher dissolution of the sludge in the $75^{\circ} \mathrm{C}$ test compared to the $50{ }^{\circ} \mathrm{C}$ test however, the amount of sludge dissolution gained by using the higher temperature remains small. Some uncertainty remains with respect to the amount of plutonium dissolved in the tank cleaning test.

The neutralization of the filtered oxalic acid solutions from the cleaning test produced a large volume of solids ( $2 \mathrm{X}$ the original sludge mass after filtration and air drying). A large portion of the increase in solids could be attributed to the formation of sodium oxalate. The data from analysis of the solid residues filtered from the neutralization tests and the filtrate 
obtained indicate most of the iron, uranium, manganese, and a large portion of the aluminum precipitated during the neutralization tests. The data for the $50{ }^{\circ} \mathrm{C}$ test and the $75{ }^{\circ} \mathrm{C}$ test show good agreement with the exception of the amount of aluminum precipitated from the neutralization. The slower addition rate of the oxalic acid filtrate to the simulated Tank $7 \mathrm{~F}$ supernate in the $75^{\circ} \mathrm{C}$ test might account for the smaller amount of aluminum precipitated and differences in the particle size/morphology and composition of the particulates. Some evidence of uranium separation from other sludge elements appears in the $75^{\circ} \mathrm{C}$ data.

The data collected from the tank cleaning and neutralization tests indicates most of the uranium dissolved during the cleaning test with oxalic acid along with the iron, aluminum, and sodium in the sludge. During the neutralization of the oxalic acid, the majority of the uranium precipitates from solution along with the iron and other typical sludge elements. The CSEM results of the $75^{\circ} \mathrm{C}$ neutralization test provide some evidence of uranium separation from other sludge elements. However, the CSEM analysis looked at a very small amount of sample, which might not be representative of the bulk material and the sludge sample also showed areas of high uranium concentration. Additionally, how the test results will scale to the full-scale neutralization in a waste tank remains uncertain.

The analysis of the oxalic acid filtrates indicates that only a small portion of the plutonium dissolved during the tank cleaning test. However, the analytical data from the solid residues filtered from the cleaning test contradict the solution data and indicate approximately half of the plutonium dissolved. The low concentration of plutonium in the test samples complicates the determination of fate of plutonium in the cleaning tests. Additional testing may be required to conclusively determine the fate of plutonium during tank cleaning with oxalic acid. The neutralization tests did not investigate plutonium distribution in the post test samples.

The uncertainty in the fate of plutonium and uranium in these tests should be weighed against the small amount of material remaining in Tank 5F. Chemical cleaning and additional mechanical sluicing planned for the tank will further reduce the inventory prior to closure. From a regulatory perspective, additional samples of the material remaining after cleaning and heel removal will be obtained to serve as the basis for compliance at tank closure. 


\subsection{INTRODUCTION}

The initial phase of bulk waste removal operations was recently completed in Tank 5F. Video inspection of the tank indicates several mounds of sludge still remain in the tank. Additionally, a mound of white solids was observed under Riser 5. In support of the chemical cleaning and heel removal programs, samples of the sludge and the mound of white solids were obtained from the tank for characterization and testing. A Technical Task Request ${ }^{1}$ (TTR) was generated requesting Savannah River National Laboratory (SRNL) to analyze samples of the sludge and identify the white solids. The TTR also requested that a portion of the sludge be contacted with oxalic acid to simulate tank cleaning operations and determine the amount of hydrogen generated during acid cleaning, evaluate layer formation during the neutralization of the acid stream, and identify the solids formed from the neutralization. A separate report documents the results of the gas generation from the tank cleaning test using oxalic acid and Tank 5F sludge. ${ }^{2}$ This document reports the characterization of the solid and liquid products generated from the tank cleaning test and subsequent neutralization of the oxalic acid solution.

A Task Technical and Quality Assurance Plan and an Analytical Study Plan were generated prior to performing the characterization and testing of the Tank 5F samples. ${ }^{3,4}$ During the course of the program, several changes/additions to the scope described in the Task Plan were made.

- $\quad$ Some of the analyses listed in the Task Plan for the white solids from Tank 5F were eliminated since the composition of the material was obtained from the XRD and SEM results.

- The oxalic acid cleaning tests were conducted at $50^{\circ} \mathrm{C}$ and $75^{\circ} \mathrm{C}$ per customer request instead of the $25^{\circ} \mathrm{C}$ and $75^{\circ} \mathrm{C}$ listed in the Task Plan. The duration of the cleaning tests were extended from the 50 hours noted in the Task Plan to 168 hours. A measurement of the viscosity of the oxalic acid containing dissolved sludge was also added to the scope.

- Tests of the neutralization of the oxalic filtrate from the cleaning tests were added per customer request along with analysis of liquid and solids phases generated from the neutralization. 


\subsection{SAMPLE DESCRIPTION AND PREPARATION}

\subsection{SAMPLE DESCRIPTION}

A sampling tool, called the Dropcore Probe, was used to obtain a sample of the sludge from a mound under Riser 5 in Tank 5F for characterization and testing. The sample of the sludge from Tank 5F was received at SRNL on 10-30-06. The Dropcore Probe has a sampling cup approximately 4" tall and $23 / 8$ " in diameter attached to the end of the probe. The sample (Sample ID = FTF-05-06-55) contained $~ 300 \mathrm{~g}$ of moist sludge solids. The photographs in Figure 2-1 show pictures of the sludge contained in the Dropcore sampler. No free liquid was obtained with the sludge sample since the design of the sampler allows any free liquid to drain during retrieval of the sampler from the tank.

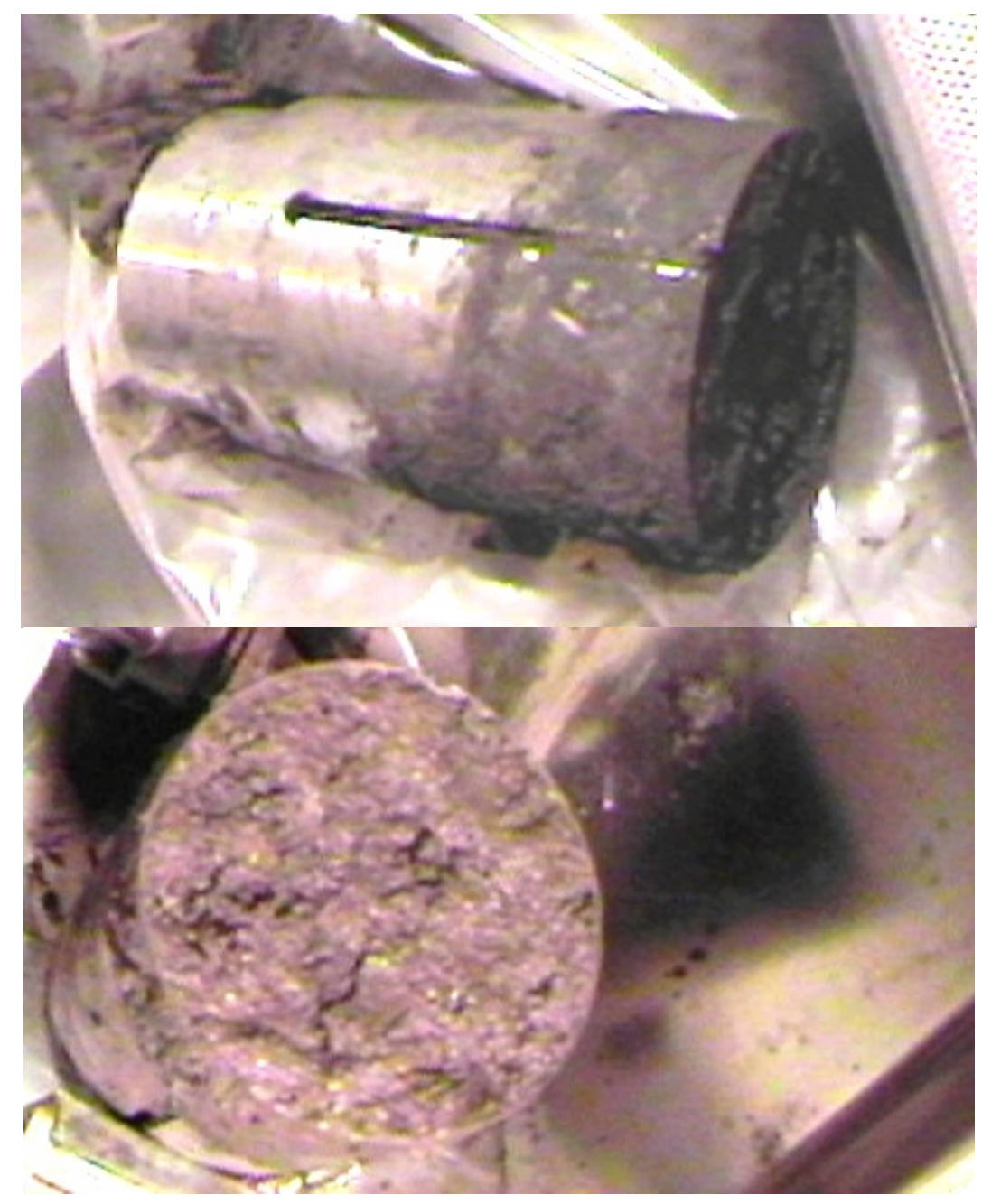

Figure 2.1 Dropcore Sampler and Sludge 
A supernate dip sample from Tank 7F, thought to be representative of the supernate in Tank 5F, was sent from CLAB to SRNL on 10-4-06. The supernate dip sample (Sample ID = FTF07-06-19) was obtained from Tank 7F on 7-12-06. The dip sample received at SRNL contained approximately $35 \mathrm{~mL}$ of supernate.

A Super Snapper sampling tool was used to obtain a sample of the white solids coating the sludge mound under Riser 5. The sample of the white solids was sent to SRNL on 2-13-07. The sampler jaws contained approximately $235 \mathrm{~g}$ of solids (Sample ID = FTF-05-07-1). The material appeared to be composed of mostly sludge solids interspersed with chunks of white solids. The photograph in Figure 2-2 shows one half of the sampler jaws with the sample material still in the jaw. Again, due to the sampler design, no free liquid was obtained from the sample.

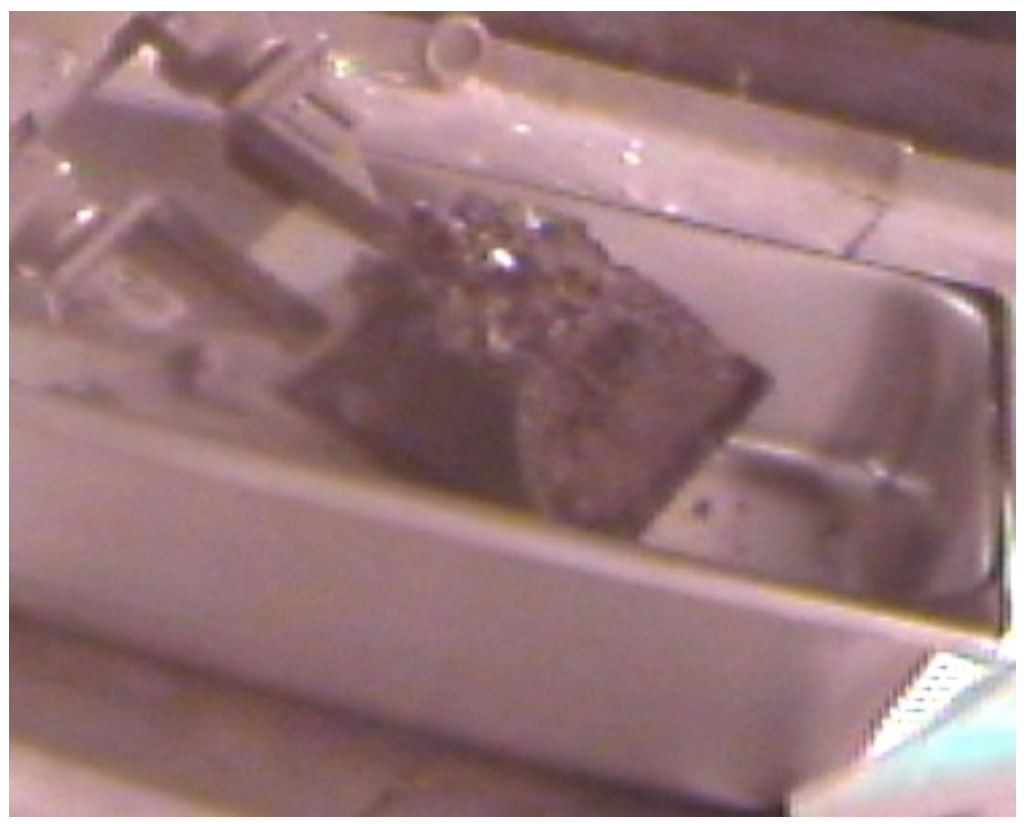

Figure 2-2 Super Snapper Sampler

\subsection{SUPERNATE SAMPLE PREPARATION FOR ANALYSIS}

The supernate dip sample from Tank 7F (FTF-07-06-19) was filtered through a $0.45 \mu$ porosity filter. Portions of the filtered supernate were diluted with de-ionized distilled water or nitric acid to reduce the sample activity and allow removal from the Shielded Cells for chemical characterization. A 15-fold dilution was required on the supernate samples to meet the dose limits for the analytical laboratories. All sample preparations of the filtered supernate samples were conducted in triplicate. A blank of the dilution medium was prepared along with the sample dilutions. 
WSRC-STI-2007-00192, REV. 1

The supernate samples were submitted for analysis by Inductively Coupled Plasma-Emission Spectroscopy (ICP-ES), Ion Chromatography (IC), Total Inorganic Carbon (TIC), free hydroxide, and mercury analysis.

\subsection{SLUDGE SAMPLE PREPARATION FOR ANALYSIS}

Samples of the as-received Tank 5F sludge solids were prepared for X-Ray Diffraction (XRD) and Contained Scanning Electron Microscopy (CSEM) analysis. Approximately 30 mg of sludge solids were weighed into a shielded bottle for XRD analysis; however, the samples could not be removed from the Shielded Cells due to high dose rates. An SEM sample post with a small square of double-sided tape was touched into the Tank 5F sludge solids to provide a small amount of material for analysis. Again, dose rates on the SEM samples were higher than standard radiation work permits allow; however, Analytical Development (AD) developed extended reach tools to allow SEM analysis of two of the three replicate samples. The CSEM was used to study the physical features of the sludge particles and their structural relationships. The CSEM also produces an EDX (Energy Dispersive Xray) spectrum, which gives a qualitative elemental analysis of the sample constituents.

Several grams of the Tank 5F sludge solids were dried in an oven at $100{ }^{\circ} \mathrm{C}$ overnight. The weight loss of the solids after drying indicates the sludge contains $\sim 23 \mathrm{wt} \%$ water indicating the presence of some interstitial supernate. Portions of dried solids were prepared for analysis by dissolution in aqua regia and fusion with sodium peroxide followed by uptake in hydrochloric acid. The digested solids were diluted to reduce activity and allow removal from the Shielded Cells. All sample preparations were conducted in triplicate. Duplicate digestions of a glass standard containing many of the elements found in tank samples were prepared concurrently with the sample digestions. Table 2-1 lists the composition of the Analytical Reference Glass-1 (ARG-1) glass standard. ${ }^{5}$ A blank was prepared concurrently with the sample preparations consisting of the digestion reagents and incorporated any manipulations and dilutions conducted on the sample.

An inhibited water contact $(0.01 \mathrm{M} \mathrm{NaOH})$ of the damp sludge solids was also conducted to allow analysis of water-soluble species present in the sludge solids. Approximately $1 \mathrm{~g}$ of damp sludge solids were contacted with $50 \mathrm{~g}$ of inhibited water, agitated, and allowed to sit for 24 hours. The sludge solids typically will not dissolve in high $\mathrm{pH}$ water, however, any interstitial supernate trapped within the sludge particles or water-soluble salts precipitated within the sludge solids can be extracted for analysis.

The aqua regia digestions of the sludge were submitted for ICP-ES, Inductively Coupled Plasma-Mass Spectrometry (ICP-MS), mercury analysis, gamma spectroscopy, ${ }^{90} \mathrm{Sr}$ analysis, ${ }^{99}$ Tc analysis, plutonium isotopic analysis, ${ }^{237} \mathrm{~Np}$ analysis, americium/curium analysis, and a total alpha determination. The sodium peroxide fusion digestions of the sludge were submitted for ICP-ES, ICP-MS, ${ }^{99}$ Tc analysis and ${ }^{237} \mathrm{~Np}$ analysis. The water contact samples of the sludge were submitted for ICP-ES, IC, TIC, and free hydroxide. 
Table 2-1. Composition of the Analytical Reference Glass-1 Standard.

\begin{tabular}{|l|c|c|}
\hline Element & wt \% in Glass & $\mathbf{~ m g / k g ~ i n ~ G l a s s ~}$ \\
\hline $\mathrm{Al}$ & 2.50 & $2.50 \mathrm{E}+04$ \\
\hline $\mathrm{B}$ & 2.69 & $2.69 \mathrm{E}+04$ \\
\hline $\mathrm{Ba}$ & 0.079 & $7.90 \mathrm{E}+02$ \\
\hline $\mathrm{Ca}$ & 1.02 & $1.02 \mathrm{E}+04$ \\
\hline $\mathrm{Cr}$ & 0.064 & $6.40 \mathrm{E}+02$ \\
\hline $\mathrm{Cu}$ & 0.003 & $3.0 \mathrm{E}+01$ \\
\hline $\mathrm{Fe}$ & 9.79 & $9.79 \mathrm{E}+04$ \\
\hline $\mathrm{K}$ & 2.26 & $2.26 \mathrm{E}+04$ \\
\hline $\mathrm{Li}$ & 1.49 & $1.49 \mathrm{E}+04$ \\
\hline $\mathrm{Mg}$ & 0.52 & $5.2 \mathrm{E}+03$ \\
\hline $\mathrm{Mn}$ & 1.46 & $1.46 \mathrm{E}+04$ \\
\hline $\mathrm{Na}$ & 8.52 & $8.52 \mathrm{E}+04$ \\
\hline $\mathrm{Ni}$ & 0.83 & $8.3 \mathrm{E}+03$ \\
\hline $\mathrm{P}$ & 0.11 & $1.1 \mathrm{E}+03$ \\
\hline $\mathrm{Si}$ & 22.4 & $2.24 \mathrm{E}+05$ \\
\hline $\mathrm{Sr}$ & 0.003 & $3.0 \mathrm{E}+01$ \\
\hline $\mathrm{Ti}$ & 0.69 & $6.9 \mathrm{E}+03$ \\
\hline $\mathrm{Zn}$ & 0.016 & $1.6 \mathrm{E}+02$ \\
\hline $\mathrm{Zr}$ & 0.096 & $9.6 \mathrm{E}+02$ \\
\hline
\end{tabular}

\subsection{SNAPPER SAMPLE (WHITE SOLIDS) PREPARATION FOR ANALYSIS}

Prior to preparation of analytical samples, the white solids in the sample were carefully picked from the sludge using tweezers. Approximately $12 \mathrm{~g}$ of white solids were isolated from the sample. The white solids could not be perfectly separated from the sludge solids and all of the nuggets of white solids had a partial coating of darker sludge solids. Figure 2-3 shows the white solids isolated from the sample. The nuggets of white solids were broken up and thoroughly mixed together prior to sample preparation. Samples of the white solids were prepared for XRD and CSEM analysis in the same manner described in section 2.3. The dose rates on these samples were much lower than those of the sludge samples.

A $1 \mathrm{~g}$ portion of the white solids was contacted with $10 \mathrm{~mL}$ de-ionized water in a small vial. After thoroughly mixing the solids and water, the water was carefully decanted away from any solids remaining in the bottom of the vial. The water contact $/ \mathrm{mix} /$ decant process was repeated two more times using $5 \mathrm{~mL}$ of de-ionized water each time. The vial containing 
residual material that was not dissolved by the water contact and the contents of a second vial containing the decanted solution from the water contacts were dried in a $60{ }^{\circ} \mathrm{C}$ oven to constant weight. Based on the weights of the dried solids from the two vials, $~ 85 \%$ of the weight of original sample used in the test was recovered. Of the solids recovered from the test, approximately $80 \%$ of the solids were water-soluble.

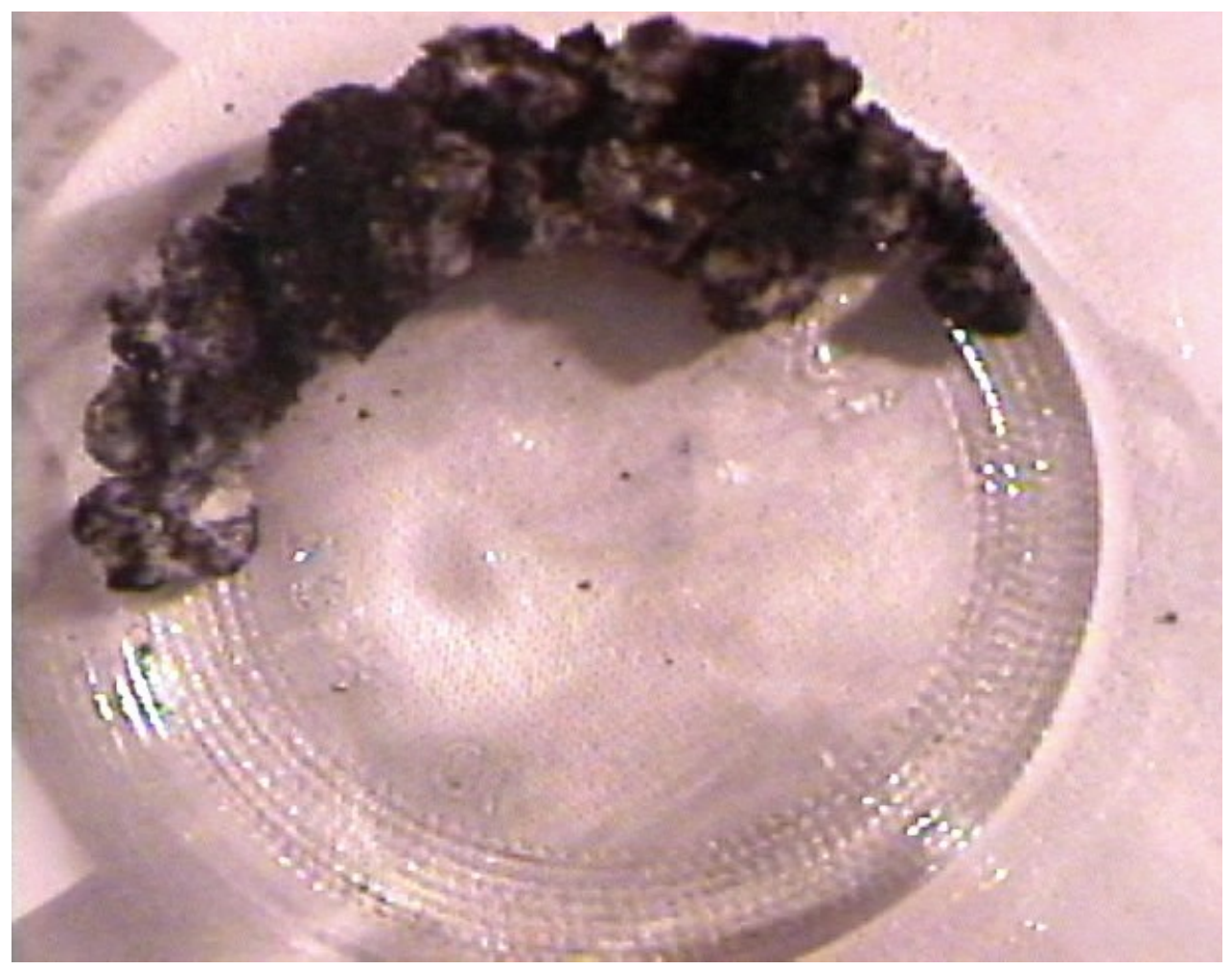

Figure 2-3 White solids (coated with sludge) isolated from the sample

\subsection{TANK CLEANING TEST SAMPLE PREPARATION}

Two tank cleaning tests with oxalic acid and Tank 5F sludge were performed.

Approximately $7 \mathrm{ml}$ of a 1:1 sludge/supernate mixture and $145 \mathrm{ml}$ of oxalic acid were used in each test. Supernate from the Tank $7 \mathrm{~F}$ dip sample was used to make the sludge/supernate mixture. The two tests, conducted at $50{ }^{\circ} \mathrm{C}$ and $75^{\circ} \mathrm{C}$, each generated a slurry of oxalic acid and undissolved sludge solids. For each test, the solids were separated from the liquid by filtration through a $0.45 \mu$ nylon filter. A portion of the oxalic acid filtrate was saved for analysis. Another portion of the oxalic acid filtrate was neutralized, at ambient temperature, by addition to a beaker containing a sufficient volume of simulated Tank 7F supernate to neutralize the acid. Table 2-2 provides the measured composition of the simulated Tank 7F supernate. ${ }^{2}$ The neutralization of the oxalic acid generated a precipitated solids fraction that was separated from the liquid by filtration through a $0.45 \mu$ nylon filter. A companion report on the gas generation from the cleaning tests contains a more detailed description. ${ }^{2}$ 
Portions of the oxalic acid filtrates from the tank cleaning tests were diluted with de-ionized distilled water to reduce the sample activity and allow removal from the Shielded Cells for chemical characterization. A 5-fold dilution was required on the samples to meet the dose limits for the analytical laboratories. A blank of the dilution medium was prepared along with the sample dilutions. Portions of the filtrates from the neutralization tests were submitted to AD with no dilution. All sample preparations of the filtrates were conducted in triplicate.

Samples of the solids filtered from the oxalic acid cleaning tests and from the neutralization tests were prepared for CSEM analysis in the same manner described in Section 2.3. The remaining solids from each test were dried in an oven at $100{ }^{\circ} \mathrm{C}$. Portions of the dried solids from each test were prepared for analysis by dissolution in aqua regia. The digested solids were diluted to reduce activity and allow removal from the Shielded Cells. All sample preparations were conducted in triplicate except for the solids from the $50{ }^{\circ} \mathrm{C}$ oxalic acid test due to the small amount of solids recovered. A glass standard containing many of the elements found in tank samples were prepared concurrently with the sample digestions. A blank was prepared concurrently with the sample preparations consisting of the digestion reagents and incorporated any manipulations and dilutions conducted on the sample.

The viscosity of the $8 \mathrm{wt} \%$ oxalic acid and the oxalic acid filtrate from the $50{ }^{\circ} \mathrm{C}$ oxalic acid cleaning test were measured using a Cannon-Fenske Routine Viscometer using Procedure L12.1, IWT-OP-067 in the Shielded Cells. The procedure was conducted at ambient cell temperature without the use of a constant temperature bath. However, the temperature in the cell remained between $24-26^{\circ} \mathrm{C}$ throughout the duration of the test. The viscometer constant was determined using water as a calibration standard. The viscosity of each solution was measured in triplicate. The average dynamic viscosity of the $8 \mathrm{wt} \%$ oxalic acid solution was $1.031 \mathrm{cp}$. The average dynamic viscosity of the $50{ }^{\circ} \mathrm{C}$ oxalic acid filtrate was $1.028 \mathrm{cp}$. The percent relative standard deviation for the triplicate measurements of each sample was less than $1 \%$. The value obtained for the $8 \mathrm{wt} \%$ oxalic acid solution shows good agreement with literature values after correction for differences in temperature. ${ }^{6}$

Table 2-2. Measured Composition of the Simulated Tank 7F Supernate

\begin{tabular}{|l|c|}
\hline Analyte & $\begin{array}{c}\text { Measured } \\
\text { Concentration }\end{array}$ \\
\hline $\mathrm{NO}_{3}{ }^{-}(\mathrm{mg} / \mathrm{L})$ & $3.69 \mathrm{E}+04$ \\
\hline $\mathrm{NO}_{2}^{-}(\mathrm{mg} / \mathrm{L})$ & $2.88 \mathrm{E}+04$ \\
\hline $\mathrm{SO}_{4}^{2-}(\mathrm{mg} / \mathrm{L})$ & $9.37 \mathrm{E}+03$ \\
\hline $\mathrm{C}_{2} \mathrm{O}_{4}{ }^{2-}(\mathrm{mg} / \mathrm{L})$ & $3.86 \mathrm{E}+02$ \\
\hline $\mathrm{Cl}^{-}(\mathrm{mg} / \mathrm{L})$ & $4.80 \mathrm{E}+02$ \\
\hline $\mathrm{F}^{-}(\mathrm{mg} / \mathrm{L})$ & $2.38 \mathrm{E}+02$ \\
\hline $\mathrm{OH}_{\text {free }}^{-}(\mathrm{M})$ & $1.06 \mathrm{E}+00$ \\
\hline $\mathrm{CO}_{3}{ }^{2-}(\mathrm{M})$ & $4.10 \mathrm{E}-01$ \\
\hline
\end{tabular}

\begin{tabular}{|l|c|}
\hline Analyte & $\begin{array}{c}\text { Measured } \\
\text { Concentration }\end{array}$ \\
\hline $\mathrm{Na}(\mathrm{mg} / \mathrm{L})$ & $7.53 \mathrm{E}+04$ \\
\hline $\mathrm{K}(\mathrm{mg} / \mathrm{L})$ & $5.29 \mathrm{E}+02$ \\
\hline $\mathrm{Al} \quad(\mathrm{mg} / \mathrm{L})$ & $4.77 \mathrm{E}+03$ \\
\hline $\mathrm{Mo}(\mathrm{mg} / \mathrm{L})$ & $1.10 \mathrm{E}+01$ \\
\hline $\mathrm{P}(\mathrm{mg} / \mathrm{L})$ & $1.79 \mathrm{E}+02$ \\
\hline $\mathrm{S}(\mathrm{mg} / \mathrm{L})$ & $2.92 \mathrm{E}+03$ \\
\hline $\mathrm{Si}(\mathrm{mg} / \mathrm{L})$ & $4.70 \mathrm{E}+01$ \\
\hline
\end{tabular}




\subsection{RESULTS OF THE SAMPLE CHARACTERIZATION}

\subsection{GENERAL INFORMATION}

Tables 3-2 through 3-13 provide the composition of the Tank 5F samples received at SRNL. Figures 3.1 through 3.63 provide the results of the XRD and CSEM analysis of the samples. Analytical results for samples use units of molarity for the supernate sample and $\mathrm{mg} / \mathrm{kg}$ of dried solids for the solids dissolution samples. (Note: To convert values in $\mathrm{mg} / \mathrm{kg}$ to a weight percent dried solids basis, divide by $1 \mathrm{E}+04$.)

The tables include the results of all replicates, blanks, and glass standards. In tables containing data for digested solids samples, the blank has been converted to solids basis to allow direct comparison to the sample data as a quality indicator. The data for the blank were converted to a solids basis by dividing the concentrations measured in the blank by the target weight of solids used in the digestion ( $0.250 \mathrm{~g}$ in most cases). For waste tank sample characterization, an uncertainty of approximately $+/-15 \%$ has been found to be the normal range for the combined sampling and analytical uncertainty. ${ }^{7}$ For the Tank 5F samples, the percent relative standard deviation (\%RSD) presented in the tables only includes the uncertainty associated with sub-sampling in the Shielded Cells and the uncertainty of the analytical method. It should be noted that the samples represent a small amount of material from a large tank.

The data tables also indicate the analytical method used to measure each analyte. Table 3-1 shows the abbreviations used for each analytical method:

\section{Table 3-1. Abbreviations for Analytical Methods used in Data Tables}

\begin{tabular}{|l|c|}
\hline Analytical Method & $\begin{array}{c}\text { Abbreviation } \\
\text { in Tables }\end{array}$ \\
\hline Inductively Coupled Plasma-Emission Spectroscopy & IE \\
\hline Inductively Coupled Plasma-Mass Spectrometry & IM \\
\hline Ion Chromatography & IC \\
\hline Titration & T \\
\hline Total Inorganic Carbon & TIC \\
\hline Atomic Absorption Cold Vapor Method & CV \\
\hline Separation/Gamma Spec. & SG \\
\hline Separation/Alpha Spec. & SA \\
\hline Separation/Liquid Scintillation & SL \\
\hline Alpha Counting & AC \\
\hline
\end{tabular}




\subsection{RESULTS OF THE ANALYSIS OF THE TANK 7F SUPERNATE SAMPLE}

Table 3-2 shows the results of the analysis of the Tank 7F supernate dip sample (FTF-07-0619). The cations ( $\mathrm{Na}, \mathrm{K})$ in the supernate sum to $3.45 \mathrm{M}$ while the anions $\left(\mathrm{NO}_{3}{ }^{-}, \mathrm{NO}_{2}{ }^{-}, \mathrm{SO}_{4}{ }^{2-}\right.$, $\mathrm{C}_{2} \mathrm{O}_{4}{ }^{2-}, \mathrm{Cl}^{-}, \mathrm{F}^{-}, \mathrm{OH}^{-}, \mathrm{P}$, and $\mathrm{Al}$ ) sum to $2.18 \mathrm{M}$ for a difference of $\sim 36 \%$. The $1.35 \mathrm{M}$ difference between the sums can probably be attributed to the carbonate anion. A carbonate concentration of $0.64 \mathrm{M}$ would be needed to balance the sums. A previous analysis of this dip sample by CLAB found a carbonate concentration of $0.44 \mathrm{M}$. Using this carbonate value would reduce the difference between the cation/anion concentration to $\sim 11 \%$. The sulfate anion concentration by IC and the sulfur concentration by ICP-ES show good agreement.

\subsection{RESULTS OF THE ANALYSIS OF THE TANK 5F SLUDGE SAMPLE}

Tables 3-3 through 3-4 show the results of the analysis of the aqua regia and sodium peroxide fusion dissolutions of the sludge solids obtained from the Tank 5F sample (FTF-05-06-55). The data quality appears quite good with respect to the tight precision of the sample replicates, good results for the glass standards, and minimal contamination found in the blanks and glass standards. The aqua regia and sodium peroxide fusion data also show good agreement between the two dissolution methods. Iron dominates the sludge composition with other major contributors being uranium, manganese, nickel, sodium, aluminum, and silicon. The low sodium value for the sludge reflects the absence of supernate present in the sample due to the core sampler employed for obtaining the sample.

Only the values from the sodium peroxide fusion data should be used for silicon since aqua regia does not dissolve silicon well. Sodium values can only be obtained from the aqua regia data since the peroxide fusion method adds sodium. Zirconium values can only be obtained from the aqua regia dissolution due to the use of zirconium crucibles in the preparation of the sodium peroxide fusion samples. The calcium results from the sodium peroxide fusion method show evidence of contamination of the blank and glass standards. The high calcium values most likely result from a calcium impurity in the reagents used for the dissolution. Subtracting the calcium values for the blank from the average value for the sample replicates results in a value much closer to that found in the aqua regia data. For both the aqua regia and sodium peroxide fusion methods, the uranium results between ICP-ES and ICP-MS show good agreement and indicate $\sim 0.6 \mathrm{wt} \%{ }^{235} \mathrm{U}$.

The results of the radiochemical analysis of the sludge show good agreement for the plutonium isotopes between the two dissolution methods. The ${ }^{241} \mathrm{Pu}$ results may have higher associated uncertainties than indicated by \%RSD due to the values being close to the method detection limit. The ${ }^{238} \mathrm{Pu}$ result of the first replicate of the peroxide fusion dissolution in Table 3-4 appears somewhat lower than the other two values leading to the higher \%RSD. The data quality for the ${ }^{137} \mathrm{Cs}$ and ${ }^{90} \mathrm{Sr}$ from the aqua regia dissolution appears quite good with low contamination found in the blanks and glass standards. Although the Am/Cm data shows some evidence of contamination in the blanks and glass standards, the levels measured in the sample were several orders of magnitude higher. The gross alpha result shows much higher alpha activity than the sum of the measured alpha emitters. The ${ }^{99}$ Tc shows a value of 
$1.31 \mathrm{E}-02 \mathrm{mCi} / \mathrm{kg}(+/-4.7 \%)$ in the peroxide fusion data and was below detection in the aqua regia data $(<1.2 \mathrm{E}-02 \mathrm{mCi} / \mathrm{kg})$. This discrepancy between the two dissolution methods may indicate the presence of a difficult to dissolve form of technetium in the sludge. Some nonpertechnetate forms of technetium require a highly oxidizing dissolution method, such as provided by the sodium peroxide fusion, to achieve complete dissolution.

Table 3-5 shows the results of the inhibited water $(0.01 \mathrm{M} \mathrm{NaOH})$ contacts with the sludge solids from the Tank 5F sample. The data indicates very little soluble material in the sludge sample consistent with the use of a core sampler that allowed the supernate to drain during removal from the tank. However, the sludge still contains some small amount of interstitial supernate as indicated by the $23 \mathrm{wt} \%$ water content of the sample when dried during the dissolution sample preparations (see Section 2.3). Most of the material dissolved from the inhibited water contact probably results from trapped interstitial supernate. The data in Table 3-5 indicates about half of the total sodium in the sludge sample would likely be removed by washing.

The CSEM results for the Tank 5F sludge sample in Figures 3.4 through 3.15 indicate the material is composed mainly of small particles of much less than $20 \mu \mathrm{m}$ with larger pieces built-up from these small particles. Each spot marked in the micrographs has an associated EDX spectrum shown in the following figures. Most of the spots examined in the micrographs show an elemental composition similar to the results of the chemical analysis. However, the spectrum of Spot 2 in Figure 3.6 may indicate an area with higher uranium content. The micrograph in Figure 3.10 shows several more areas with the same elevated uranium composition as found in Spot 2.

\subsection{RESULTS OF THE ANALYSIS OF THE TANK 5F SNAPPER (WHITE SOLIDS) SAMPLE}

Figures 3.1 through 3.3 show the XRD results for the three replicate samples of the white solids obtained from the Tank 5F Super Snapper sample (FTF-05-07-1). The spectra indicate the white solids contain hydrated sodium carbonate and bicarbonate along with the some aluminum hydroxide. Assuming the composition of the Tank 7F supernate approximates the Tank 5F supernate, the compounds identified in the XRD analysis could reasonably be expected to precipitate from the supernate liquid after slight evaporation in the tank or due to changes in $\mathrm{pH}$. The Tank 7F supernate had a moderately high aluminate concentration $(0.1$ $\mathrm{M})$ and a high carbonate concentration $(0.44 \mathrm{M})$. All of the hydrated carbonate salts would be expected to be fairly soluble in water. As described in Section 2.4, a solubility test of the white solids found that $\sim 85 \%$ dissolved in water.

Figures 3.16 through 3.23 show the micrographs and spectra from the CSEM analysis of the white solids. The material appears highly crystalline and EDX spectra substantiate the XRD results. All of the spectra for the various spots on the micrographs indicate a composition of mainly sodium, carbon, and oxygen consistent with the presence of sodium carbonates. 
WSRC-STI-2007-00192, REV. 1

\subsection{RESULTS OF THE ANALYSIS OF THE TANK 5F SIMULATED TANK CLEANING TEST SAMPLES}

Tables 3-6 and 3-7 show the analysis of the aqua regia dissolution of the solids filtered from the oxalic acid solution at the conclusion of the $50{ }^{\circ} \mathrm{C}$ and $75^{\circ} \mathrm{C}$ simulated tank cleaning tests. The small amount of solids recovered from the filter from the $50{ }^{\circ} \mathrm{C}$ test precluded the use of multiple sample replicates. However, the data from the $50{ }^{\circ} \mathrm{C}$ test appears consistent with the results from the $75^{\circ} \mathrm{C}$ test. In both tests, the solid residues filtered from the oxalic acid solution show a material with markedly reduced concentrations of iron, uranium, and aluminum and rich in nickel compared to the original Tank 5F sludge. The manganese and plutonium show concentrations similar to the original Tank 5F sludge. The $75^{\circ} \mathrm{C}$ data in Table 3-7 show a much greater reduction in iron concentrations and a larger increase in the nickel concentration compared to the $50{ }^{\circ} \mathrm{C}$ data. The $50{ }^{\circ} \mathrm{C}$ data in Table 3-6 shows a discrepancy in the uranium concentration as measured by ICP-ES versus ICP-MS. The magnitude of the lower value from the ICP-ES for the $50{ }^{\circ} \mathrm{C}$ data shows consistency with the uranium value from the $75{ }^{\circ} \mathrm{C}$ data by both ICP-ES and ICP-MS. The silicon values in both tables should be considered unreliable since aqua regia does not dissolve silicon well.

Figures 3.24 through 3.48 show the micrographs and EDX spectra of the solids filtered from the oxalic acid solution at the conclusion of the $50{ }^{\circ} \mathrm{C}$ and $75^{\circ} \mathrm{C}$ simulated tank cleaning tests. The spectra for Spot 1 for the $50^{\circ} \mathrm{C}$ oxalic acid filtrate (Figure 3.25) and the $75{ }^{\circ} \mathrm{C}$ oxalic acid filtrate (Figure 3.36) show a composition similar to the as-received Tank 5F sludge (Figure 3.5) but higher in nickel and manganese consistent with the chemical analysis. For both samples, the spectra indicate areas with higher uranium and other areas with higher iron content similar to what was found in the as-received Tank 5F sludge.

The analytical results for the oxalic acid filtrates from the two tank cleaning tests in Tables 38 and 3-9 show consistency with the solids results described in the previous paragraph. The major elements dissolved in the oxalic acid include iron, uranium, and aluminum as expected based on the solid residue analysis. Essentially no nickel was detected in the oxalic acid, but small amounts of plutonium were found. The data between the two tests show good agreement however; the higher temperature of the $75^{\circ} \mathrm{C}$ test dissolved more of the sludge as evidenced by the slightly higher concentrations of the major elements in Table 3-9. As noted in Section 2.5, the viscosity of the oxalic acid solution remained essentially unchanged after dissolution of the sludge components into the acid.

Tables 3-10 and 3-11 show the analytical results for the aqua regia digestions of the solids filtered from the slurry after neutralization of a portion of the oxalic acid filtrate from the tank cleaning tests using a simulated Tank 7 supernate. Both neutralizations precipitated a significant amount of solids. Some of those solids were undoubtedly sodium oxalate that can not be identified from the ICP-ES data. Based on the data in the tables, iron, aluminum, and uranium show the highest concentrations of the elements analyzed. The only significant difference in the data for the $50^{\circ} \mathrm{C}$ and $75^{\circ} \mathrm{C}$ oxalic acid neutralizations appears to be the much lower precipitation of aluminum from the $75^{\circ} \mathrm{C}$ oxalic acid neutralization. 
The precipitated solids from the neutralization tests visually appear quite different than the Tank 5F sludge solids or the solids filtered from the oxalic acid cleaning test. Figures 3.49 through 3.64 show the micrographs and EDX spectra of the solids. Although the neutralization for both tests were conducted at ambient temperature, the two neutralization tests will be referred to as the $50{ }^{\circ} \mathrm{C}$ neutralization test and the $75^{\circ} \mathrm{C}$ neutralization test. Both the neutralization solids from the $50^{\circ} \mathrm{C}$ and $75^{\circ} \mathrm{C}$ tank cleaning tests appear more crystalline than the Tank $5 \mathrm{~F}$ sludge solids. Additionally, differences can be seen between the solids from the $50{ }^{\circ} \mathrm{C}$ and $75^{\circ} \mathrm{C}$ neutralization tests. The material from the $50{ }^{\circ} \mathrm{C}$ test shows uniformly larger particles with a distinctive broccoli head shape. The bulk of the material from the 50 ${ }^{\circ} \mathrm{C}$ neutralization test shows only sodium and oxygen in the EDX spectrum (Figures 3.50 and 3.53) probably indicating the presence of sodium oxalate. Spot 2 in Figure 3.52 shows several particles composed of aluminum and oxygen that could be precipitated aluminum hydroxide. Spots 4 and 5 in Figures 3.55 and 3.57 indicate areas with elemental composition more analogous with the Tank 5F sludge. The CSEM results for the material from the $75{ }^{\circ} \mathrm{C}$ test again shows an elemental composition for the bulk material consisting of sodium and oxygen, but also indicates growth of a uranium phase separated from other typical sludge elements. In the micrographs of Figures 3.58 and 3.61 and the EDX spectra of Figures 3.60 and 3.63, a crystalline uranium phase can be seen with little or no iron, aluminum, manganese or nickel present.

Tables 3-12 and 3-13 show the results of the analysis of the filtrates from the oxalic acid neutralizations. The data for the two neutralization tests appears consistent. Most of the iron and uranium in both tests precipitated during the neutralizations as evidenced by the much lower concentrations when compared to the oxalic acid filtrate data in Tables 3-8 and 3-9. The data shows slightly higher concentrations of aluminum and uranium in the filtrate from the neutralization of the oxalic acid from the $75{ }^{\circ} \mathrm{C}$ test versus the $50{ }^{\circ} \mathrm{C}$ test consistent with the solids analytical data. 
WSRC-STI-2007-00192, REV. 1

Table 3-2. Composition of the Supernate Dip Sample FTF-07-06-19 from Tank 7F

\begin{tabular}{|c|c|c|c|c|c|c|}
\hline Analyte (Method) & $\begin{array}{c}\text { 1st } \\
\text { Replicate } \\
\text { (M) }\end{array}$ & $\begin{array}{c}\text { 2nd } \\
\text { Replicate } \\
\text { (M) }\end{array}$ & $\begin{array}{c}\text { 3rd } \\
\text { Replicate } \\
\text { (M) }\end{array}$ & $\begin{array}{c}\text { Average } \\
\text { (M) }\end{array}$ & $\%$ RSD & $\begin{array}{c}\text { Blank } \\
\text { (M) }\end{array}$ \\
\hline $\mathrm{NO}_{3}^{-}$(IC) & 3.75E-01 & 4.67E-01 & 3.76E-01 & 4.06E-01 & $13 \%$ & 4.95E-03 \\
\hline $\mathrm{NO}_{2}^{-}$(IC) & $6.25 \mathrm{E}-01$ & $6.26 \mathrm{E}-01$ & 5.70E-01 & 6.07E-01 & $5.2 \%$ & $<3.3 \mathrm{E}-03$ \\
\hline $\mathrm{SO}_{4}{ }^{2-}$ (IC) & 6.02E-02 & 4.31E-02 & 4.05E-02 & 4.80E-02 & $22 \%$ & $<8.0 \mathrm{E}-04$ \\
\hline $\mathrm{C}_{2} \mathrm{O}_{4}{ }^{2-}$ (IC) & 7.14E-03 & 8.63E-03 & 8.95E-03 & 8.24E-03 & $12 \%$ & $<1.7 \mathrm{E}-03$ \\
\hline $\mathrm{Cl}^{-}$(IC) & 5.32E-03 & 4.02E-03 & $3.48 \mathrm{E}-03$ & 4.27E-03 & $22 \%$ & $<8.7 \mathrm{E}-04$ \\
\hline $\mathrm{F}^{-}$(IC) & 3.31E-03 & 3.33E-03 & $3.25 \mathrm{E}-03$ & 3.30E-03 & $1.3 \%$ & $<1.6 \mathrm{E}-03$ \\
\hline $\mathrm{OH}_{\text {free }}^{-}(\mathrm{T})$ & 7.26E-01 & $1.11 \mathrm{E}+00$ & 9.56E-01 & 9.31E-01 & $21 \%$ & $<3.1 \mathrm{E}-02$ \\
\hline $\mathrm{Na}$ (IE) & $3.45 \mathrm{E}+00$ & $3.44 \mathrm{E}+00$ & $3.40 \mathrm{E}+00$ & $3.43 \mathrm{E}+00$ & $0.7 \%$ & $5.21 \mathrm{E}-03$ \\
\hline K (IE) & $1.84 \mathrm{E}-02$ & $1.88 \mathrm{E}-02$ & 1.83E-02 & $1.85 \mathrm{E}-02$ & $1.4 \%$ & $<4.4 \mathrm{E}-03$ \\
\hline $\mathrm{Al}$ (IE) & $1.00 \mathrm{E}-01$ & $9.91 \mathrm{E}-02$ & $1.00 \mathrm{E}-01$ & $1.00 \mathrm{E}-01$ & $0.8 \%$ & $<1.2 \mathrm{E}-04$ \\
\hline Cr (IE) & $1.29 \mathrm{E}-03$ & $1.34 \mathrm{E}-03$ & 1.39E-03 & $1.34 \mathrm{E}-03$ & $3.7 \%$ & $<3.2 \mathrm{E}-04$ \\
\hline $\mathrm{Fe}$ (IE) & $<1.2 \mathrm{E}-04$ & $<1.1 \mathrm{E}-04$ & $<1.2 \mathrm{E}-04$ & - & - & $<1.2 \mathrm{E}-04$ \\
\hline Mn (IE) & $<1.5 \mathrm{E}-04$ & $<1.4 \mathrm{E}-04$ & $<1.5 \mathrm{E}-04$ & - & - & $<1.5 \mathrm{E}-04$ \\
\hline P (IE) & 4.45E-03 & 4.57E-03 & 4.33E-03 & 4.45E-03 & $2.6 \%$ & $<1.8 \mathrm{E}-03$ \\
\hline S (IE) & 4.49E-02 & 4.45E-02 & $4.50 \mathrm{E}-02$ & 4.48E-02 & $0.6 \%$ & $<3.0 \mathrm{E}-04$ \\
\hline U (IE) & $<1.7 \mathrm{E}-04$ & $<1.6 \mathrm{E}-04$ & $<1.7 \mathrm{E}-04$ & - & - & $<1.7 \mathrm{E}-04$ \\
\hline Hg (CV) & $<8.6 \mathrm{E}-06$ & $<8.1 \mathrm{E}-06$ & $<8.3 \mathrm{E}-06$ & - & - & $<8.4 \mathrm{E}-06$ \\
\hline
\end{tabular}


Table 3-3. Composition of the Aqua Regia Dissolution of Solids from Tank 5F Sludge Sample FTF-05-06-55

\begin{tabular}{|c|c|c|c|c|c|c|c|c|}
\hline Analyte (Method) & $\begin{array}{c}\text { 1st } \\
\text { Replicate } \\
(\mathrm{mg} / \mathrm{kg})\end{array}$ & $\begin{array}{c}\text { 2nd } \\
\text { Replicate } \\
(\mathrm{mg} / \mathrm{kg})\end{array}$ & $\begin{array}{c}\text { 3rd } \\
\text { Replicate } \\
\text { (mg/kg) } \\
\end{array}$ & $\begin{array}{c}\text { Average } \\
\text { (mg/kg) }\end{array}$ & \%RSD & $\begin{array}{c}\text { Blank } \\
(\mathrm{mg} / \mathrm{kg})\end{array}$ & $\begin{array}{c}\text { Avg Analyzed } \\
\text { Glass Std } \\
\text { (mg/kg) } \\
\end{array}$ & \begin{tabular}{|c|}
$\begin{array}{c}\text { Glass Std } \\
\text { Composition } \\
(\mathrm{mg} / \mathrm{kg})\end{array}$ \\
\end{tabular} \\
\hline Ag (IE) & $<4.3 \mathrm{E}+02$ & $5.14 \mathrm{E}+02$ & $4.59 \mathrm{E}+02$ & $4.86 \mathrm{E}+02$ & $7.9 \%$ & $<4.3 \mathrm{E}+02$ & $<4.3 \mathrm{E}+02$ & - \\
\hline $\mathrm{Al}$ (IE) & $1.34 \mathrm{E}+04$ & $1.55 \mathrm{E}+04$ & $1.39 \mathrm{E}+04$ & $1.43 \mathrm{E}+04$ & $7.9 \%$ & $<2.2 \mathrm{E}+02$ & $2.24 \mathrm{E}+04$ & $2.50 \mathrm{E}+04$ \\
\hline B (IE) & $<9.3 \mathrm{E}+02$ & $<8.9 \mathrm{E}+02$ & $<9.4 \mathrm{E}+02$ & - & - & $<9.2 \mathrm{E}+02$ & $2.29 \mathrm{E}+04$ & $2.69 \mathrm{E}+04$ \\
\hline $\mathrm{Ba}$ (IE) & $1.79 \mathrm{E}+03$ & $1.85 \mathrm{E}+03$ & $1.79 \mathrm{E}+03$ & $1.81 \mathrm{E}+03$ & $2.0 \%$ & $<2.3 \mathrm{E}+02$ & $6.77 \mathrm{E}+02$ & $7.90 \mathrm{E}+02$ \\
\hline Ca (IE) & $3.43 E+03$ & $3.51 \mathrm{E}+03$ & $3.48 \mathrm{E}+03$ & $3.47 \mathrm{E}+03$ & $1.2 \%$ & $<5.9 \mathrm{E}+02$ & $1.04 \mathrm{E}+04$ & $1.02 \mathrm{E}+04$ \\
\hline Cd (IE) & $<6.2 \mathrm{E}+02$ & $<5.9 \mathrm{E}+02$ & $<6.2 \mathrm{E}+02$ & - & - & $<6.1 \mathrm{E}+02$ & $<6.2 \mathrm{E}+02$ & - \\
\hline Ce (IE) & $3.94 \mathrm{E}+03$ & $4.42 \mathrm{E}+03$ & $4.31 \mathrm{E}+03$ & $4.22 \mathrm{E}+03$ & $5.9 \%$ & $<3.0 \mathrm{E}+03$ & $<3.1 \mathrm{E}+03$ & - \\
\hline $\mathrm{Cr}$ (IE) & $<1.1 \mathrm{E}+03$ & $<1.1 \mathrm{E}+03$ & $<1.1 \mathrm{E}+03$ & - & - & $<1.1 \mathrm{E}+03$ & $<1.1 \mathrm{E}+03$ & $6.40 \mathrm{E}+02$ \\
\hline $\mathrm{Cu}$ (IE) & $6.63 E+02$ & $6.69 \mathrm{E}+02$ & $6.50 \mathrm{E}+02$ & $6.61 \mathrm{E}+02$ & $1.5 \%$ & $<3.4 \mathrm{E}+02$ & $<3.5 \mathrm{E}+02$ & $3.00 \mathrm{E}+01$ \\
\hline Fe (IE) & $4.10 \mathrm{E}+05$ & $3.72 E+05$ & $3.66 \mathrm{E}+05$ & $3.83 \mathrm{E}+05$ & $6.3 \%$ & $<4.3 \mathrm{E}+02$ & $9.74 \mathrm{E}+04$ & $9.79 \mathrm{E}+04$ \\
\hline Gd (IE) & $<5.1 \mathrm{E}+02$ & $<4.9 \mathrm{E}+02$ & $<5.2 \mathrm{E}+02$ & - & - & $<5.1 \mathrm{E}+02$ & $<5.1 \mathrm{E}+02$ & - \\
\hline K (IE) & $<1.1 \mathrm{E}+04$ & $<1.1 \mathrm{E}+04$ & $<1.1 \mathrm{E}+04$ & - & - & $<1.1 \mathrm{E}+04$ & $2.33 \mathrm{E}+04$ & $2.26 \mathrm{E}+04$ \\
\hline La (IE) & $1.69 \mathrm{E}+03$ & $1.84 \mathrm{E}+03$ & $1.80 \mathrm{E}+03$ & $1.78 \mathrm{E}+03$ & $4.3 \%$ & $<9.9 \mathrm{E}+02$ & $<1.0 \mathrm{E}+03$ & - \\
\hline Li (IE) & $6.08 \mathrm{E}+02$ & $7.22 \mathrm{E}+02$ & $6.34 \mathrm{E}+02$ & $6.55 \mathrm{E}+02$ & $9.1 \%$ & $<4.8 \mathrm{E}+02$ & $1.63 \mathrm{E}+04$ & $1.49 \mathrm{E}+04$ \\
\hline Mg (IE) & $<8.6 \mathrm{E}+02$ & $<8.3 \mathrm{E}+02$ & $<8.7 \mathrm{E}+02$ & - & - & $<8.6 \mathrm{E}+02$ & $4.88 \mathrm{E}+03$ & $5.20 \mathrm{E}+03$ \\
\hline Mn (IE) & $6.72 E+04$ & $6.81 \mathrm{E}+04$ & $7.16 \mathrm{E}+04$ & $6.90 \mathrm{E}+04$ & $3.4 \%$ & $<5.3 \mathrm{E}+02$ & $1.43 \mathrm{E}+04$ & $1.46 \mathrm{E}+04$ \\
\hline Mo (IE) & $<3.2 \mathrm{E}+03$ & $<3.0 \mathrm{E}+03$ & $<3.2 \mathrm{E}+03$ & - & - & $<3.1 \mathrm{E}+03$ & $<3.2 \mathrm{E}+03$ & - \\
\hline $\mathrm{Na}$ (IE) & $3.92 E+04$ & $4.49 E+04$ & $4.37 \mathrm{E}+04$ & $4.26 \mathrm{E}+04$ & $7.0 \%$ & $<1.9 \mathrm{E}+03$ & $8.51 \mathrm{E}+04$ & $8.52 E+04$ \\
\hline
\end{tabular}

Divide $\mathrm{mg} / \mathrm{kg}$ values by $1 \mathrm{E}+04$ to convert to wt \% dried solids basis 
Table 3-3. Composition of the Aqua Regia Dissolution of Solids from Tank 5F Sludge Sample FTF-05-06-55 (continued)

\begin{tabular}{|c|c|c|c|c|c|c|c|c|}
\hline Analyte (Method) & $\begin{array}{c}\text { 1st } \\
\text { Replicate } \\
\text { (mg/kg) }\end{array}$ & $\begin{array}{c}\text { 2nd } \\
\text { Replicate } \\
\text { (mg/kg) }\end{array}$ & $\begin{array}{c}\text { 3rd } \\
\text { Replicate } \\
\text { (mg/kg) } \\
\end{array}$ & $\begin{array}{c}\text { Average } \\
\text { (mg/kg) }\end{array}$ & \%RSD & $\begin{array}{c}\text { Blank } \\
\text { (mg/kg) }\end{array}$ & $\begin{array}{c}\text { Avg Analyzed } \\
\text { Glass Std } \\
(\mathrm{mg} / \mathrm{kg})\end{array}$ & \begin{tabular}{|c|} 
Glass Std \\
Composition \\
(mg/kg)
\end{tabular} \\
\hline $\mathrm{Ni}$ (IE) & $4.32 \mathrm{E}+04$ & $4.93 E+04$ & $4.61 E+04$ & $4.62 \mathrm{E}+04$ & $6.6 \%$ & $<2.0 \mathrm{E}+03$ & $7.92 E+03$ & $8.27 E+03$ \\
\hline$P$ (IE) & $<3.7 \mathrm{E}+03$ & $<3.5 \mathrm{E}+03$ & $<3.7 \mathrm{E}+03$ & - & - & $<3.6 \mathrm{E}+03$ & $<3.7 \mathrm{E}+03$ & $1.10 \mathrm{E}+03$ \\
\hline $\mathrm{Pb}$ (IE) & $<5.9 \mathrm{E}+03$ & $<5.6 \mathrm{E}+03$ & $<5.9 \mathrm{E}+03$ & - & - & $<5.8 \mathrm{E}+03$ & $<5.9 \mathrm{E}+03$ & - \\
\hline S (IE) & $<6.3 \mathrm{E}+02$ & $<6.0 \mathrm{E}+02$ & $<6.4 \mathrm{E}+02$ & - & - & $2.25 \mathrm{E}+03$ & $<6.3 \mathrm{E}+02$ & - \\
\hline $\mathrm{Sb}$ (IE) & $<2.8 \mathrm{E}+04$ & $<2.7 \mathrm{E}+04$ & $<2.8 \mathrm{E}+04$ & - & - & $<2.8 \mathrm{E}+04$ & $<2.8 \mathrm{E}+04$ & - \\
\hline Si (IE) & $<7.4 \mathrm{E}+03$ & $<7.1 \mathrm{E}+03$ & $<7.5 \mathrm{E}+03$ & - & - & $<7.3 \mathrm{E}+03$ & $<7.6 \mathrm{E}+03$ & $2.24 \mathrm{E}+05$ \\
\hline Sn (IE) & $5.32 E+03$ & $5.80 \mathrm{E}+03$ & $5.88 \mathrm{E}+03$ & $5.67 \mathrm{E}+03$ & $5.3 \%$ & $<4.9 \mathrm{E}+03$ & $<5.0 \mathrm{E}+03$ & - \\
\hline Sr (IE) & $1.26 \mathrm{E}+03$ & $1.33 \mathrm{E}+03$ & $1.29 \mathrm{E}+03$ & $1.29 \mathrm{E}+03$ & $2.8 \%$ & $<4.3 \mathrm{E}+02$ & $1.81 \mathrm{E}+03$ & $3.00 \mathrm{E}+01$ \\
\hline Ti (IE) & $<5.3 \mathrm{E}+02$ & $<5.1 \mathrm{E}+02$ & $<5.4 \mathrm{E}+02$ & - & - & $<5.3 \mathrm{E}+02$ & $5.78 \mathrm{E}+03$ & $6.90 \mathrm{E}+03$ \\
\hline U (IE) & $1.02 \mathrm{E}+05$ & $1.10 \mathrm{E}+05$ & $1.08 \mathrm{E}+05$ & $1.07 \mathrm{E}+05$ & $4.0 \%$ & $<1.9 \mathrm{E}+03$ & $5.73 \mathrm{E}+03$ & - \\
\hline V (IE) & $<2.9 \mathrm{E}+03$ & $<2.8 \mathrm{E}+03$ & $<2.9 \mathrm{E}+03$ & - & - & $<2.9 \mathrm{E}+03$ & $<2.9 \mathrm{E}+03$ & - \\
\hline $\mathrm{Zn}$ (IE) & $<1.2 \mathrm{E}+03$ & $<1.1 \mathrm{E}+03$ & $<1.2 \mathrm{E}+03$ & - & - & $<1.2 \mathrm{E}+03$ & $<1.2 \mathrm{E}+03$ & $1.60 \mathrm{E}+02$ \\
\hline $\mathrm{Zr}$ (IE) & $3.34 \mathrm{E}+03$ & $4.33 E+03$ & $4.07 \mathrm{E}+03$ & $3.91 \mathrm{E}+03$ & $13 \%$ & $<1.7 \mathrm{E}+03$ & $<1.7 \mathrm{E}+03$ & $9.60 \mathrm{E}+02$ \\
\hline $\mathrm{Hg}(\mathrm{CV})$ & $1.23 \mathrm{E}+03$ & $1.37 \mathrm{E}+03$ & $1.28 \mathrm{E}+03$ & $1.29 \mathrm{E}+03$ & $5.6 \%$ & $<1.1 \mathrm{E}+02$ & $<1.1 \mathrm{E}+02$ & - \\
\hline${ }^{233} \mathrm{U}$ (IM) & $<1.0 \mathrm{E}+00$ & $<9.7 \mathrm{E}-01$ & $<1.0 \mathrm{E}+00$ & - & - & $<1.0 \mathrm{E}+00$ & $<1.0 \mathrm{E}+00$ & - \\
\hline${ }^{234} \mathrm{U}$ (IM) & $8.14 \mathrm{E}+00$ & $7.42 \mathrm{E}+00$ & $6.98 \mathrm{E}+00$ & $7.51 \mathrm{E}+00$ & $7.8 \%$ & $<1.0 \mathrm{E}+00$ & $<1.0 \mathrm{E}+00$ & - \\
\hline${ }^{235} \mathrm{U}$ (IM) & $5.72 \mathrm{E}+02$ & $6.19 \mathrm{E}+02$ & $6.05 \mathrm{E}+02$ & $5.99 \mathrm{E}+02$ & $4.1 \%$ & $<1.0 \mathrm{E}+00$ & $<1.0 \mathrm{E}+00$ & - \\
\hline${ }^{236} \mathrm{U}$ (IM) & $3.57 \mathrm{E}+01$ & $3.81 \mathrm{E}+01$ & $3.65 E+01$ & $3.68 \mathrm{E}+01$ & $3.4 \%$ & $<1.5 \mathrm{E}+00$ & $<1.5 \mathrm{E}+00$ & - \\
\hline${ }^{238} \mathrm{U}$ (IM) & $9.47 \mathrm{E}+04$ & $1.01 \mathrm{E}+05$ & $1.00 \mathrm{E}+05$ & $9.87 \mathrm{E}+04$ & $3.5 \%$ & $<2.5 \mathrm{E}+00$ & $7.92 \mathrm{E}+00$ & - \\
\hline U total (IM) & $9.54 \mathrm{E}+04$ & $1.02 \mathrm{E}+05$ & $1.01 \mathrm{E}+05$ & $9.93 \mathrm{E}+04$ & $3.5 \%$ & $<7.0 \mathrm{E}+00$ & $<1.2 \mathrm{E}+01$ & - \\
\hline
\end{tabular}

Divide $\mathrm{mg} / \mathrm{kg}$ values by $1 \mathrm{E}+04$ to convert to wt \% dried solids basis 
Table 3-3. Composition of the Aqua Regia Dissolution of Solids from Tank 5F Sludge Sample FTF-05-06-55 (continued)

\begin{tabular}{|c|c|c|c|c|c|c|c|c|}
\hline Analyte (Method) & $\begin{array}{c}\text { 1st } \\
\text { Replicate } \\
(\mathrm{mCi} / \mathrm{kg}) \\
\end{array}$ & $\begin{array}{c}\text { 2nd } \\
\text { Replicate } \\
\text { (mCi/kg) } \\
\end{array}$ & $\begin{array}{c}\text { 3rd } \\
\text { Replicate } \\
(\mathrm{mCi} / \mathrm{kg}) \\
\end{array}$ & $\begin{array}{l}\text { Average } \\
(\mathbf{m C i} / \mathbf{k g})\end{array}$ & \%RSD & $\begin{array}{c}\text { Blank } \\
(\mathrm{mCi} / \mathrm{kg}) \\
\end{array}$ & $\begin{array}{c}\begin{array}{c}\text { Avg Analyzed } \\
\text { Glass Std } \\
\text { (mCi/kg) }\end{array} \\
\end{array}$ & \begin{tabular}{|c|}
$\begin{array}{c}\text { Glass Std } \\
\text { Composition } \\
(\mathrm{mCi} / \mathrm{kg})\end{array}$ \\
\end{tabular} \\
\hline${ }^{99}$ Tc (SL) & $<1.1 \mathrm{E}-02$ & $<1.2 \mathrm{E}-02$ & $<1.2 \mathrm{E}-02$ & - & - & $<3.7 \mathrm{E}-03$ & $<3.7 \mathrm{E}-03$ & - \\
\hline${ }^{137} \mathrm{Cs}$ (SG) & $1.07 \mathrm{E}+03$ & $1.10 \mathrm{E}+03$ & $1.10 \mathrm{E}+03$ & $1.09 \mathrm{E}+03$ & $1.5 \%$ & $<2.8 \mathrm{E}+00$ & $<3.0 \mathrm{E}+00$ & - \\
\hline${ }^{154} \mathrm{Eu}$ (SG) & $3.12 \mathrm{E}+01$ & $3.03 E+01$ & $2.95 \mathrm{E}+01$ & $3.03 \mathrm{E}+01$ & $2.9 \%$ & - & - & - \\
\hline${ }^{60}$ Co (SG) & $1.35 \mathrm{E}+01$ & $1.53 \mathrm{E}+01$ & $1.27 \mathrm{E}+01$ & $1.39 \mathrm{E}+01$ & $9.7 \%$ & - & - & - \\
\hline${ }^{90} \mathrm{Sr}$ (SL) & $4.34 \mathrm{E}+04$ & $3.69 E+04$ & $3.06 \mathrm{E}+04$ & $3.70 \mathrm{E}+04$ & $17 \%$ & $<1.1 \mathrm{E}+00$ & $6.33 \mathrm{E}+00$ & - \\
\hline${ }^{237} \mathrm{~Np}(\mathrm{SA})$ & $<9.2 \mathrm{E}-02$ & $<9.0 \mathrm{E}-02$ & $<9.4 \mathrm{E}-02$ & - & - & $<8.8 \mathrm{E}-02$ & $<8.7 \mathrm{E}-02$ & - \\
\hline${ }^{238} \mathrm{Pu}(\mathrm{SA})$ & $1.87 \mathrm{E}+00$ & $2.05 \mathrm{E}+00$ & $2.13 \mathrm{E}+00$ & $2.02 E+00$ & $6.6 \%$ & $2.09 \mathrm{E}-02$ & $<4.0 \mathrm{E}-02$ & - \\
\hline${ }^{239 / 240} \mathrm{Pu}$ (SA) & $7.72 \mathrm{E}+00$ & $8.35 \mathrm{E}+00$ & $9.05 \mathrm{E}+00$ & $8.37 \mathrm{E}+00$ & $8.0 \%$ & $<3.4 \mathrm{E}-02$ & $<7.6 \mathrm{E}-02$ & - \\
\hline${ }^{241} \mathrm{Pu}(\mathrm{SA})$ & $7.72 \mathrm{E}+00$ & $8.35 \mathrm{E}+00$ & $9.05 \mathrm{E}+00$ & $8.37 \mathrm{E}+00$ & $8.0 \%$ & $<1.5 \mathrm{E}+00$ & $<1.5 \mathrm{E}+00$ & - \\
\hline${ }^{241} \mathrm{Am}$ (SG) & $4.72 \mathrm{E}+01$ & $5.61 \mathrm{E}+01$ & $4.87 \mathrm{E}+01$ & $5.07 \mathrm{E}+01$ & $9.4 \%$ & $5.18 \mathrm{E}-02$ & $3.22 \mathrm{E}-02$ & - \\
\hline${ }^{243} \mathrm{Am}$ (SA) & $3.21 \mathrm{E}-01$ & $3.68 \mathrm{E}-01$ & 3.17E-01 & 3.35E-01 & $8.4 \%$ & $3.26 \mathrm{E}-03$ & $2.01 \mathrm{E}-03$ & - \\
\hline${ }^{242 \mathrm{~m}} \mathrm{Am}(\mathrm{SA})$ & $1.48 \mathrm{E}-01$ & $1.45 \mathrm{E}-01$ & $1.48 \mathrm{E}-01$ & $1.47 \mathrm{E}-01$ & $1.0 \%$ & $4.59 \mathrm{E}-04$ & $2.09 \mathrm{E}-04$ & - \\
\hline${ }^{242} \mathrm{Cm}(\mathrm{SA})$ & $1.23 \mathrm{E}-01$ & $1.20 \mathrm{E}-01$ & $1.22 \mathrm{E}-01$ & $1.21 \mathrm{E}-01$ & $1.1 \%$ & $<3.8 \mathrm{E}-04$ & $<1.7 \mathrm{E}-04$ & - \\
\hline${ }^{244} \mathrm{Cm}(\mathrm{SA})$ & $3.76 \mathrm{E}+00$ & $3.94 \mathrm{E}+00$ & $3.87 \mathrm{E}+00$ & $3.86 \mathrm{E}+00$ & $2.5 \%$ & $1.55 \mathrm{E}-03$ & $6.92 \mathrm{E}-03$ & - \\
\hline Gross Alpha & $5.13 \mathrm{E}+02$ & $6.65 \mathrm{E}+02$ & $6.39 \mathrm{E}+02$ & $6.06 \mathrm{E}+02$ & $13 \%$ & $<1.8 \mathrm{E}+02$ & $<2.3 \mathrm{E}+02$ & - \\
\hline
\end{tabular}


Table 3-4. Composition of the Sodium Peroxide Fusion Dissolution of Solids from Tank 5F Sludge Sample FTF-05-06-55

\begin{tabular}{|c|c|c|c|c|c|c|c|c|}
\hline Analyte (Method) & $\begin{array}{c}\text { 1st } \\
\text { Replicate } \\
(\mathrm{mg} / \mathrm{kg})\end{array}$ & $\begin{array}{c}\text { 2nd } \\
\text { Replicate } \\
\text { (mg/kg) }\end{array}$ & $\begin{array}{c}\text { 3rd } \\
\text { Replicate } \\
\text { (mg/kg) }\end{array}$ & $\begin{array}{c}\text { Average } \\
\text { (mg/kg) }\end{array}$ & \%RSD & $\begin{array}{c}\text { Blank } \\
(\mathrm{mg} / \mathrm{kg})\end{array}$ & $\begin{array}{c}\text { Avg Analyzed } \\
\text { Glass Std } \\
\text { (mg/kg) } \\
\end{array}$ & \begin{tabular}{|c|c|}
$\begin{array}{c}\text { Glass Std } \\
\text { Composition } \\
(\mathrm{mg} / \mathrm{kg})\end{array}$ \\
\end{tabular} \\
\hline Ag (IE) & $6.73 \mathrm{E}+02$ & $8.60 \mathrm{E}+02$ & $8.24 \mathrm{E}+02$ & $7.85 \mathrm{E}+02$ & $13 \%$ & $5.26 \mathrm{E}+02$ & $8.81 \mathrm{E}+02$ & - \\
\hline Al (IE) & $2.22 \mathrm{E}+04$ & $1.48 \mathrm{E}+04$ & $1.45 \mathrm{E}+04$ & $1.72 E+04$ & $25 \%$ & $7.40 \mathrm{E}+02$ & $2.37 \mathrm{E}+04$ & $2.50 \mathrm{E}+04$ \\
\hline B (IE) & $<9.0 \mathrm{E}+02$ & $<9.4 \mathrm{E}+02$ & $<9.0 \mathrm{E}+02$ & - & - & $<9.2 \mathrm{E}+02$ & $2.40 \mathrm{E}+04$ & $2.69 \mathrm{E}+04$ \\
\hline $\mathrm{Ba}$ (IE) & $1.71 \mathrm{E}+03$ & $1.88 \mathrm{E}+03$ & $1.88 \mathrm{E}+03$ & $1.82 \mathrm{E}+03$ & $5.5 \%$ & $<2.3 \mathrm{E}+02$ & $7.72 \mathrm{E}+02$ & $7.90 \mathrm{E}+02$ \\
\hline Ca (IE) & $4.92 \mathrm{E}+03$ & $5.27 \mathrm{E}+03$ & $5.11 \mathrm{E}+03$ & $5.10 \mathrm{E}+03$ & $3.5 \%$ & $1.29 \mathrm{E}+03$ & $1.25 E+04$ & $1.02 \mathrm{E}+04$ \\
\hline Cd (IE) & $<6.0 \mathrm{E}+02$ & $<6.2 \mathrm{E}+02$ & $<5.9 \mathrm{E}+02$ & - & - & $<6.1 \mathrm{E}+02$ & $<6.1 \mathrm{E}+02$ & - \\
\hline Ce (IE) & $4.85 E+03$ & $5.83 \mathrm{E}+03$ & $5.56 \mathrm{E}+03$ & $5.42 \mathrm{E}+03$ & $9.4 \%$ & $<3.0 \mathrm{E}+03$ & $<3.1 \mathrm{E}+03$ & - \\
\hline Cr (IE) & $<1.1 \mathrm{E}+03$ & $<1.1 \mathrm{E}+03$ & $<1.1 \mathrm{E}+03$ & - & - & $<1.1 \mathrm{E}+03$ & $<1.1 \mathrm{E}+03$ & $6.40 \mathrm{E}+02$ \\
\hline $\mathrm{Cu}$ (IE) & $6.20 \mathrm{E}+02$ & $6.59 \mathrm{E}+02$ & $6.48 \mathrm{E}+02$ & $6.42 \mathrm{E}+02$ & $3.1 \%$ & $<3.4 \mathrm{E}+02$ & $<3.4 \mathrm{E}+02$ & $3.00 \mathrm{E}+01$ \\
\hline Fe (IE) & $3.71 \mathrm{E}+05$ & $3.60 \mathrm{E}+05$ & $3.60 \mathrm{E}+05$ & $3.63 \mathrm{E}+05$ & $1.7 \%$ & $<4.3 \mathrm{E}+02$ & $1.01 \mathrm{E}+05$ & $9.79 \mathrm{E}+04$ \\
\hline Gd (IE) & $<5.0 \mathrm{E}+02$ & $5.29 \mathrm{E}+02$ & $5.19 \mathrm{E}+02$ & $5.24 \mathrm{E}+02$ & $1.4 \%$ & $<5.1 \mathrm{E}+02$ & $<5.0 \mathrm{E}+02$ & - \\
\hline $\mathrm{K}$ (IE) & $<1.1 \mathrm{E}+04$ & $<1.1 \mathrm{E}+04$ & $<1.1 \mathrm{E}+04$ & - & - & $<1.1 \mathrm{E}+04$ & $2.77 \mathrm{E}+04$ & $2.26 \mathrm{E}+04$ \\
\hline La (IE) & $1.75 E+03$ & $2.04 \mathrm{E}+03$ & $1.98 \mathrm{E}+03$ & $1.93 \mathrm{E}+03$ & $7.9 \%$ & $<9.9 \mathrm{E}+02$ & $<9.9 \mathrm{E}+02$ & - \\
\hline Li (IE) & $8.78 \mathrm{E}+02$ & $9.82 \mathrm{E}+02$ & $9.48 \mathrm{E}+02$ & $9.36 \mathrm{E}+02$ & $5.6 \%$ & $<4.8 \mathrm{E}+02$ & $1.77 \mathrm{E}+04$ & $1.49 \mathrm{E}+04$ \\
\hline Mg (IE) & $<8.4 \mathrm{E}+02$ & $<8.7 \mathrm{E}+02$ & $<8.3 \mathrm{E}+02$ & - & - & $<8.6 \mathrm{E}+02$ & $4.92 \mathrm{E}+03$ & $5.20 \mathrm{E}+03$ \\
\hline Mn (IE) & $6.50 \mathrm{E}+04$ & $6.89 \mathrm{E}+04$ & $6.97 \mathrm{E}+04$ & $6.79 \mathrm{E}+04$ & $3.7 \%$ & $<5.3 \mathrm{E}+02$ & $1.47 \mathrm{E}+04$ & $1.46 \mathrm{E}+04$ \\
\hline Mo (IE) & $<3.1 \mathrm{E}+03$ & $<3.2 \mathrm{E}+03$ & $<3.1 \mathrm{E}+03$ & - & - & $<3.1 \mathrm{E}+03$ & $<3.1 \mathrm{E}+03$ & - \\
\hline $\mathrm{Ni}$ (IE) & $3.83 \mathrm{E}+04$ & $4.55 \mathrm{E}+04$ & $4.43 \mathrm{E}+04$ & $4.27 \mathrm{E}+04$ & $9.0 \%$ & $<2.0 \mathrm{E}+03$ & $8.07 \mathrm{E}+03$ & $8.27 \mathrm{E}+03$ \\
\hline
\end{tabular}

Divide $\mathrm{mg} / \mathrm{kg}$ values by $1 \mathrm{E}+04$ to convert to wt \% dried solids basis 
Table 3-4. Composition of the Sodium Peroxide Fusion Dissolution of Solids from Tank 5F Sludge Sample FTF-05-06-55 (continued)

\begin{tabular}{|c|c|c|c|c|c|c|c|c|}
\hline Analyte (Method) & $\begin{array}{c}\text { 1st } \\
\text { Replicate } \\
(\mathrm{mg} / \mathrm{kg})\end{array}$ & $\begin{array}{c}\text { 2nd } \\
\text { Replicate } \\
(\mathrm{mg} / \mathrm{kg})\end{array}$ & $\begin{array}{c}\text { 3rd } \\
\text { Replicate } \\
\text { (mg/kg) }\end{array}$ & $\begin{array}{c}\text { Average } \\
\text { (mg/kg) }\end{array}$ & \%RSD & $\begin{array}{c}\text { Blank } \\
\text { (mg/kg) }\end{array}$ & \begin{tabular}{|c}
$\begin{array}{c}\text { Avg Analyzed } \\
\text { Glass Std } \\
(\mathrm{mg} / \mathrm{kg})\end{array}$ \\
\end{tabular} & \begin{tabular}{|c|} 
Glass Std \\
Composition \\
(mg/kg)
\end{tabular} \\
\hline $\mathrm{P}$ (IE) & $<3.6 \mathrm{E}+03$ & $<3.7 \mathrm{E}+03$ & $<3.5 \mathrm{E}+03$ & - & - & $<3.6 \mathrm{E}+03$ & $<3.6 \mathrm{E}+03$ & $1.10 \mathrm{E}+03$ \\
\hline $\mathrm{Pb}$ (IE) & $<5.7 \mathrm{E}+03$ & $<5.9 \mathrm{E}+03$ & $<5.7 \mathrm{E}+03$ & - & - & $<5.8 \mathrm{E}+03$ & $<5.8 \mathrm{E}+03$ & - \\
\hline S (IE) & $<6.1 \mathrm{E}+02$ & $<6.3 \mathrm{E}+02$ & $<6.1 \mathrm{E}+02$ & - & - & $<6.2 \mathrm{E}+02$ & $<6.2 \mathrm{E}+02$ & - \\
\hline Sb (IE) & $<2.7 \mathrm{E}+04$ & $<2.8 \mathrm{E}+04$ & $<2.7 \mathrm{E}+04$ & - & - & $<2.8 \mathrm{E}+04$ & $<2.8 \mathrm{E}+04$ & - \\
\hline Si (IE) & $1.13 \mathrm{E}+04$ & $1.22 \mathrm{E}+04$ & $1.21 \mathrm{E}+04$ & $1.18 \mathrm{E}+04$ & $4.2 \%$ & $<7.3 \mathrm{E}+03$ & $2.36 \mathrm{E}+05$ & $2.24 \mathrm{E}+05$ \\
\hline Sn (IE) & $7.87 \mathrm{E}+03$ & $8.17 \mathrm{E}+03$ & $8.50 \mathrm{E}+03$ & $8.18 \mathrm{E}+03$ & $3.8 \%$ & $6.19 \mathrm{E}+03$ & $8.95 E+03$ & - \\
\hline Sr (IE) & $1.62 \mathrm{E}+03$ & $1.80 \mathrm{E}+03$ & $1.71 \mathrm{E}+03$ & $1.71 \mathrm{E}+03$ & $5.3 \%$ & $<4.3 \mathrm{E}+02$ & $2.40 \mathrm{E}+03$ & $3.00 \mathrm{E}+01$ \\
\hline Ti (IE) & $<5.2 \mathrm{E}+02$ & $<5.3 \mathrm{E}+02$ & $<5.1 \mathrm{E}+02$ & - & - & $<5.3 \mathrm{E}+02$ & $7.01 \mathrm{E}+03$ & $6.90 \mathrm{E}+03$ \\
\hline U (IE) & $9.31 \mathrm{E}+04$ & $1.09 \mathrm{E}+05$ & $1.06 \mathrm{E}+05$ & $1.03 \mathrm{E}+05$ & $8.1 \%$ & $<1.9 \mathrm{E}+03$ & $7.19 \mathrm{E}+03$ & - \\
\hline V (IE) & $<2.8 \mathrm{E}+03$ & $<2.9 \mathrm{E}+03$ & $<2.8 \mathrm{E}+03$ & - & - & $<2.9 \mathrm{E}+03$ & $<2.9 \mathrm{E}+03$ & - \\
\hline $\mathrm{Zn}$ (IE) & $<1.2 \mathrm{E}+03$ & $<1.2 \mathrm{E}+03$ & $<1.2 \mathrm{E}+03$ & - & - & $<1.2 \mathrm{E}+03$ & $<1.2 \mathrm{E}+03$ & $1.60 \mathrm{E}+02$ \\
\hline${ }^{233} \mathrm{U}$ (IM) & $<9.8 \mathrm{E}+00$ & $<1.0 \mathrm{E}+01$ & $<9.7 \mathrm{E}+00$ & - & - & $<1.0 \mathrm{E}+01$ & $<9.9 \mathrm{E}+00$ & - \\
\hline${ }^{234} \mathrm{U}$ (IM) & $<9.8 \mathrm{E}+00$ & $<1.0 \mathrm{E}+01$ & $<1.0 \mathrm{E}+01$ & - & - & $<1.0 \mathrm{E}+01$ & $<9.9 \mathrm{E}+00$ & - \\
\hline${ }^{235} \mathrm{U}$ (IM) & $5.55 \mathrm{E}+02$ & $6.28 \mathrm{E}+02$ & $6.07 \mathrm{E}+02$ & $5.97 \mathrm{E}+02$ & $6.3 \%$ & $<1.0 \mathrm{E}+01$ & $<9.9 \mathrm{E}+00$ & - \\
\hline${ }^{236} \mathrm{U}$ (IM) & $2.85 E+01$ & $4.02 \mathrm{E}+01$ & $3.98 \mathrm{E}+01$ & $3.62 \mathrm{E}+01$ & $18 \%$ & $<2.0 \mathrm{E}+01$ & $<2.0 \mathrm{E}+01$ & - \\
\hline${ }^{238} \mathrm{U}$ (IM) & $8.06 \mathrm{E}+04$ & $1.02 \mathrm{E}+05$ & $9.46 \mathrm{E}+04$ & $9.23 \mathrm{E}+04$ & $12 \%$ & $1.06 \mathrm{E}+02$ & $9.66 \mathrm{E}+01$ & - \\
\hline U total (IM) & $8.12 E+04$ & $1.02 \mathrm{E}+05$ & $9.52 E+04$ & $9.29 \mathrm{E}+04$ & $12 \%$ & $<1.6 \mathrm{E}+02$ & $<1.5 \mathrm{E}+02$ & - \\
\hline
\end{tabular}

Divide $\mathrm{mg} / \mathrm{kg}$ values by $1 \mathrm{E}+04$ to convert to wt \% dried solids basis 
Table 3-4. Composition of the Sodium Peroxide Fusion Dissolution of Solids from Tank 5F Sludge Sample FTF-05-06-55 (continued)

\begin{tabular}{|l|c|c|c|c|c|c|c|c|}
\hline & $\begin{array}{c}\text { 1st } \\
\text { Replicate } \\
\text { Analyte (Method) }\end{array}$ & $\begin{array}{c}\text { 2nd } \\
\text { Replicate } \\
\text { (mCi/kg) }\end{array}$ & $\begin{array}{c}\text { 3rd } \\
\text { Replicate } \\
\text { (mCi/kg) }\end{array}$ & $\begin{array}{c}\text { Average } \\
\text { (mCi/kg) }\end{array}$ & \%RSD & $\begin{array}{c}\text { Blank } \\
\text { (mCi/kg) }\end{array}$ & $\begin{array}{c}\text { Avg Analyzed } \\
\text { Glass Std } \\
\text { (mCi/kg) }\end{array}$ & $\begin{array}{c}\text { Glass Std } \\
\text { Composition } \\
\text { (mCi/kg) }\end{array}$ \\
\hline${ }^{99} \mathrm{Tc}(\mathrm{SL})$ & $1.25 \mathrm{E}-02$ & $1.30 \mathrm{E}-02$ & $1.37 \mathrm{E}-02$ & $1.31 \mathrm{E}-02$ & $4.7 \%$ & $<3.5 \mathrm{E}-03$ & $<3.2 \mathrm{E}-03$ & - \\
\hline${ }^{237} \mathrm{~Np}(\mathrm{SA})$ & $<5.3 \mathrm{E}-02$ & $<2.3 \mathrm{E}-02$ & $<5.5 \mathrm{E}-02$ & - & - & $<5.4 \mathrm{E}-02$ & $<3.7 \mathrm{E}-02$ & - \\
\hline${ }^{238} \mathrm{Pu}(\mathrm{SA})$ & $1.49 \mathrm{E}+00$ & $2.12 \mathrm{E}+00$ & $2.03 \mathrm{E}+00$ & $1.88 \mathrm{E}+00$ & $18 \%$ & $<9.8 \mathrm{E}-02$ & $<7.2 \mathrm{E}-02$ & - \\
\hline${ }^{239 / 240} \mathrm{Pu}(\mathrm{SA})$ & $8.26 \mathrm{E}+00$ & $8.97 \mathrm{E}+00$ & $8.54 \mathrm{E}+00$ & $8.59 \mathrm{E}+00$ & $4.2 \%$ & $<7.7 \mathrm{E}-02$ & $<4.9 \mathrm{E}-02$ & - \\
\hline${ }^{241} \mathrm{Pu}(\mathrm{SA})$ & $7.90 \mathrm{E}+00$ & $7.23 \mathrm{E}+00$ & $8.06 \mathrm{E}+00$ & $7.73 \mathrm{E}+00$ & $5.7 \%$ & $<3.4 \mathrm{E}+00$ & $<1.7 \mathrm{E}+00$ & - \\
\hline
\end{tabular}


Table 3-5. Composition of the Inhibited Water Contact of Solids from Tank 5F Sludge Sample FTF-05-06-55

\begin{tabular}{|c|c|c|c|c|c|c|}
\hline Analyte & $\begin{array}{c}\text { 1st } \\
\text { Replicate } \\
\text { (mg/kg) }\end{array}$ & $\begin{array}{c}\text { 2nd } \\
\text { Replicate } \\
\text { (mg/kg) }\end{array}$ & $\begin{array}{c}\text { 3rd } \\
\text { Replicate } \\
\text { (mg/kg) }\end{array}$ & $\begin{array}{c}\text { Average } \\
\text { (mg/kg) }\end{array}$ & \%RSD & $\begin{array}{c}\text { Blank } \\
\text { (mg/kg) }\end{array}$ \\
\hline $\mathrm{NO}_{3}^{-}$(IC) & $7.68 \mathrm{E}+02$ & $7.63 \mathrm{E}+02$ & $7.39 \mathrm{E}+02$ & $7.57 \mathrm{E}+02$ & $2.0 \%$ & $<5.0 \mathrm{E}+02$ \\
\hline $\mathrm{NO}_{2}^{-}$(IC) & $1.15 \mathrm{E}+03$ & $1.14 \mathrm{E}+03$ & $1.13 \mathrm{E}+03$ & $1.14 \mathrm{E}+03$ & $0.8 \%$ & $<5.0 \mathrm{E}+02$ \\
\hline $\mathrm{SO}_{4}^{2-}(\mathrm{IC})$ & $2.88 \mathrm{E}+02$ & $2.86 \mathrm{E}+02$ & $2.46 \mathrm{E}+02$ & $2.73 E+02$ & $8.6 \%$ & $<2.5 \mathrm{E}+02$ \\
\hline $\mathrm{C}_{2} \mathrm{O}_{4}{ }^{2-}$ (IC) & $1.92 \mathrm{E}+02$ & $1.91 \mathrm{E}+02$ & $1.97 \mathrm{E}+02$ & $1.93 \mathrm{E}+02$ & $1.8 \%$ & $<5.0 \mathrm{E}+02$ \\
\hline $\mathrm{Cl}^{-}$(IC) & $<9.6 \mathrm{E}+01$ & $<9.5 \mathrm{E}+01$ & $<9.9 \mathrm{E}+01$ & - & - & $<9.9 \mathrm{E}+01$ \\
\hline $\mathrm{F}^{-}$(IC) & $<9.6 \mathrm{E}+01$ & $<9.5 \mathrm{E}+01$ & $<9.9 \mathrm{E}+01$ & - & - & $<9.9 \mathrm{E}+01$ \\
\hline Al (IE) & $1.90 \mathrm{E}+02$ & $1.77 \mathrm{E}+02$ & $2.08 \mathrm{E}+02$ & $1.92 \mathrm{E}+02$ & $8.2 \%$ & $<8.7 \mathrm{E}+00$ \\
\hline Ca (IE) & $<9.0 \mathrm{E}+00$ & $<9.0 \mathrm{E}+00$ & $<9.3 \mathrm{E}+00$ & - & - & $<9.3 \mathrm{E}+00$ \\
\hline Cr (IE) & $<1.4 \mathrm{E}+01$ & $<1.4 \mathrm{E}+01$ & $<1.4 \mathrm{E}+01$ & - & - & $<1.4 \mathrm{E}+01$ \\
\hline $\mathrm{Fe}$ (IE) & $<4.0 \mathrm{E}+00$ & $<4.0 \mathrm{E}+00$ & $<4.1 \mathrm{E}+00$ & - & - & $<4.1 \mathrm{E}+00$ \\
\hline K (IE) & $<7.7 \mathrm{E}+02$ & $<7.6 \mathrm{E}+02$ & $<7.9 \mathrm{E}+02$ & - & - & $<7.9 \mathrm{E}+02$ \\
\hline Mn (IE) & $<7.7 \mathrm{E}-01$ & $<7.6 \mathrm{E}-01$ & $<7.9 \mathrm{E}-01$ & - & - & $<7.9 \mathrm{E}-01$ \\
\hline $\mathrm{Na}$ (IE) & $1.97 \mathrm{E}+04$ & $1.98 \mathrm{E}+04$ & $1.93 \mathrm{E}+04$ & $1.96 \mathrm{E}+04$ & $1.3 \%$ & $1.38 \mathrm{E}+04$ \\
\hline $\mathrm{P}$ (IE) & $<1.5 \mathrm{E}+02$ & $<1.5 \mathrm{E}+02$ & $<1.6 \mathrm{E}+02$ & - & - & $<1.6 \mathrm{E}+02$ \\
\hline S (IE) & $1.24 \mathrm{E}+02$ & $1.10 \mathrm{E}+02$ & $1.02 \mathrm{E}+02$ & $1.12 \mathrm{E}+02$ & $10 \%$ & $<4.9 \mathrm{E}+01$ \\
\hline Si (IE) & $<8.8 \mathrm{E}+00$ & $<8.7 \mathrm{E}+00$ & $<9.0 \mathrm{E}+00$ & - & - & $<9.1 \mathrm{E}+00$ \\
\hline U (IE) & $5.85 \mathrm{E}+01$ & $5.53 \mathrm{E}+01$ & $5.91 \mathrm{E}+01$ & $5.77 \mathrm{E}+01$ & $3.6 \%$ & $<4.1 \mathrm{E}+01$ \\
\hline
\end{tabular}

Results are on mg per kg of as-received (undried) sludge solids. An estimate of the results on a dried solids basis can be obtained by multiply by 1.3 . 
WSRC-STI-2007-00192, REV. 1

Table 3-6. Composition of the Aqua Regia Dissolution of Solid Residues from $50{ }^{\circ} \mathrm{C}$ Oxalic Acid Cleaning Test

\begin{tabular}{|c|c|c|}
\hline Analyte (Method) & $\begin{array}{c}\text { 1st } \\
\text { Replicate } \\
\text { (mg/kg) }\end{array}$ & $\begin{array}{c}\text { Blank } \\
\text { (mg/kg) }\end{array}$ \\
\hline Ag (IE) & $<1.5 \mathrm{E}+02$ & $<1.7 \mathrm{E}+02$ \\
\hline $\mathrm{Al}$ (IE) & $2.05 E+03$ & $<2.4 \mathrm{E}+02$ \\
\hline B (IE) & $<3.5 \mathrm{E}+02$ & $<3.8 \mathrm{E}+02$ \\
\hline Ba (IE) & $5.00 \mathrm{E}+02$ & $<2.1 \mathrm{E}+02$ \\
\hline Ca (IE) & $4.15 \mathrm{E}+02$ & $<2.3 \mathrm{E}+02$ \\
\hline Cd (IE) & $9.64 \mathrm{E}+01$ & $<7.7 \mathrm{E}+01$ \\
\hline Ce (IE) & $5.04 \mathrm{E}+03$ & $<5.1 \mathrm{E}+03$ \\
\hline Cr (IE) & $<3.6 \mathrm{E}+02$ & $<3.9 \mathrm{E}+02$ \\
\hline $\mathrm{Cu}(\mathrm{IE})$ & $9.73 \mathrm{E}+02$ & $<2.7 \mathrm{E}+01$ \\
\hline Fe (IE) & $2.56 \mathrm{E}+05$ & $<5.8 \mathrm{E}+01$ \\
\hline Gd (IE) & $2.25 E+02$ & $<2.2 \mathrm{E}+02$ \\
\hline K (IE) & $<5.7 \mathrm{E}+03$ & $<6.3 \mathrm{E}+03$ \\
\hline La (IE) & $2.26 \mathrm{E}+03$ & $<1.1 \mathrm{E}+03$ \\
\hline $\mathrm{Li}$ (IE) & $<6.2 \mathrm{E}+02$ & $<6.9 \mathrm{E}+02$ \\
\hline Mg (IE) & $2.22 \mathrm{E}+02$ & $<1.3 \mathrm{E}+02$ \\
\hline Mn (IE) & $6.41 \mathrm{E}+04$ & $<1.7 \mathrm{E}+01$ \\
\hline Mo (IE) & $<1.8 \mathrm{E}+03$ & $<2.0 \mathrm{E}+03$ \\
\hline $\mathrm{Na}$ (IE) & $4.77 \mathrm{E}+03$ & $<2.1 \mathrm{E}+02$ \\
\hline
\end{tabular}

Divide $\mathrm{mg} / \mathrm{kg}$ values by $1 \mathrm{E}+04$ to convert to wt \% dried solids basis 
WSRC-STI-2007-00192, REV. 1

Table 3-6. Composition of the Aqua Regia Dissolution of Solid Residues from $50{ }^{\circ} \mathrm{C}$ Oxalic Acid Cleaning Test (continued)

\begin{tabular}{|c|c|c|}
\hline Analyte (Method) & $\begin{array}{c}\text { 1st } \\
\text { Replicate } \\
\text { (mg/kg) }\end{array}$ & $\begin{array}{c}\text { Blank } \\
\text { (mg/kg) }\end{array}$ \\
\hline $\mathrm{Ni}$ (IE) & $7.52 \mathrm{E}+04$ & $<5.7 \mathrm{E}+02$ \\
\hline $\mathrm{P}$ (IE) & $<3.4 \mathrm{E}+03$ & $<3.7 \mathrm{E}+03$ \\
\hline $\mathrm{Pb}$ (IE) & $<4.4 \mathrm{E}+03$ & $<4.9 \mathrm{E}+03$ \\
\hline S (IE) & $<1.2 \mathrm{E}+03$ & $<1.3 \mathrm{E}+03$ \\
\hline $\mathrm{Sb}$ (IE) & $1.38 \mathrm{E}+03$ & $<1.2 \mathrm{E}+03$ \\
\hline Si (IE) & $9.07 \mathrm{E}+02$ & $<2.3 \mathrm{E}+02$ \\
\hline Sn (IE) & $<1.0 \mathrm{E}+04$ & $<1.1 \mathrm{E}+04$ \\
\hline Sr (IE) & $<6.4 \mathrm{E}+02$ & $<7.0 \mathrm{E}+02$ \\
\hline Ti (IE) & $5.18 \mathrm{E}+01$ & $<3.8 \mathrm{E}+01$ \\
\hline U (IE) & $4.40 \mathrm{E}+03$ & $<4.5 \mathrm{E}+02$ \\
\hline V (IE) & $<1.3 \mathrm{E}+02$ & $<1.4 \mathrm{E}+02$ \\
\hline Zn (IE) & $5.11 \mathrm{E}+02$ & $<3.0 \mathrm{E}+02$ \\
\hline Zr (IE) & $4.80 \mathrm{E}+02$ & $<7.9 \mathrm{E}+01$ \\
\hline${ }^{233} \mathrm{U}(\mathrm{IM})$ & $<1.8 \mathrm{E}+02$ & $<1.0 \mathrm{E}+00$ \\
\hline${ }^{234} \mathrm{U}$ (IM) & $<5.5 \mathrm{E}+02$ & $<3.0 \mathrm{E}+00$ \\
\hline${ }^{235} \mathrm{U}(\mathrm{IM})$ & $1.15 E+03$ & $<1.5 \mathrm{E}+00$ \\
\hline${ }^{236} \mathrm{U}$ (IM) & $<2.7 \mathrm{E}+02$ & $<1.5 \mathrm{E}+00$ \\
\hline${ }^{238} \mathrm{U}$ (IM) & $1.96 \mathrm{E}+05$ & $<1.0 \mathrm{E}+01$ \\
\hline U total (IM) & $1.98 \mathrm{E}+05$ & $<1.7 \mathrm{E}+01$ \\
\hline
\end{tabular}

Divide $\mathrm{mg} / \mathrm{kg}$ values by $1 \mathrm{E}+04$ to convert to wt \% dried solids basis 
WSRC-STI-2007-00192, REV. 1

Table 3-6. Composition of the Aqua Regia Dissolution of Solid Residues from $50{ }^{\circ} \mathrm{C}$ Oxalic Acid Cleaning Test (continued)

\begin{tabular}{|l|c|c|}
\hline Analyte (Method) & $\begin{array}{c}\text { 1st } \\
\text { Replicate } \\
\text { (mCi/kg) }\end{array}$ & $\begin{array}{c}\text { Blank } \\
\text { (mCi/kg) }\end{array}$ \\
\hline${ }^{99} \mathrm{Tc}$ (SL) & $<2.9 \mathrm{E}-03$ & $<3.3 \mathrm{E}-03$ \\
\hline${ }^{237} \mathrm{~Np}$ (SA) & $<5.6 \mathrm{E}-03$ & $-^{\mathrm{a}}$ \\
\hline${ }^{238} \mathrm{Pu}$ (SA) & $1.65 \mathrm{E}+00$ & $<5.1 \mathrm{E}-03$ \\
\hline${ }^{239 / 240} \mathrm{Pu}(\mathrm{SA})$ & $6.88 \mathrm{E}+00$ & $<6.5 \mathrm{E}-03$ \\
\hline${ }^{241} \mathrm{Pu}$ (SA) & $<8.2 \mathrm{E}+00$ & $3.65 \mathrm{E}-01$ \\
\hline
\end{tabular}

a - No yield was obtained for ${ }^{237} \mathrm{~Np}$ on the blank so a lower limit on the concentration could not be provided. 
Table 3-7. Composition of the Aqua Regia Dissolution of Solid Residues from $75{ }^{\circ} \mathrm{C}$ Oxalic Acid Cleaning Test

\begin{tabular}{|c|c|c|c|c|c|c|c|c|}
\hline Analyte (Method) & $\begin{array}{c}\text { 1st } \\
\text { Replicate } \\
(\mathrm{mg} / \mathrm{kg})\end{array}$ & $\begin{array}{c}\text { 2nd } \\
\text { Replicate } \\
\text { (mg/kg) } \\
\end{array}$ & $\begin{array}{c}\text { 3rd } \\
\text { Replicate } \\
\text { (mg/kg) } \\
\end{array}$ & $\begin{array}{c}\text { Average } \\
\text { (mg/kg) }\end{array}$ & \%RSD & $\begin{array}{c}\text { Blank } \\
\text { (mg/kg) }\end{array}$ & $\begin{array}{l}\text { Avg Analyzed } \\
\text { Glass Std } \\
\text { (mg/kg) }\end{array}$ & \begin{tabular}{|c|}
$\begin{array}{c}\text { Glass Std } \\
\text { Composition } \\
(\mathrm{mg} / \mathrm{kg})\end{array}$ \\
\end{tabular} \\
\hline Ag (IE) & $<1.5 \mathrm{E}+02$ & $<1.5 \mathrm{E}+02$ & $<1.5 \mathrm{E}+02$ & - & - & $<1.7 \mathrm{E}+02$ & $<1.4 \mathrm{E}+02$ & - \\
\hline $\mathrm{Al}$ (IE) & $1.48 \mathrm{E}+03$ & $1.35 \mathrm{E}+03$ & $1.57 \mathrm{E}+03$ & $1.47 \mathrm{E}+03$ & $7.4 \%$ & $<2.4 \mathrm{E}+02$ & $2.49 \mathrm{E}+04$ & $2.50 \mathrm{E}+04$ \\
\hline B (IE) & $<3.4 \mathrm{E}+02$ & $<3.5 \mathrm{E}+02$ & $<3.4 \mathrm{E}+02$ & - & - & $<3.8 \mathrm{E}+02$ & $2.62 \mathrm{E}+04$ & $2.69 \mathrm{E}+04$ \\
\hline Ba (IE) & $2.34 \mathrm{E}+02$ & $2.32 \mathrm{E}+02$ & $2.48 \mathrm{E}+02$ & $2.38 \mathrm{E}+02$ & $3.6 \%$ & $<2.1 \mathrm{E}+02$ & $8.89 \mathrm{E}+02$ & $7.90 \mathrm{E}+02$ \\
\hline Ca (IE) & $<2.0 \mathrm{E}+02$ & $<2.1 \mathrm{E}+02$ & $<2.0 \mathrm{E}+02$ & - & - & $<2.3 \mathrm{E}+02$ & $1.09 \mathrm{E}+04$ & $1.02 \mathrm{E}+04$ \\
\hline Cd (IE) & $<6.9 \mathrm{E}+01$ & $<7.1 \mathrm{E}+01$ & $<6.8 \mathrm{E}+01$ & - & - & $<7.7 \mathrm{E}+01$ & $<6.6 \mathrm{E}+01$ & - \\
\hline Ce (IE) & $1.03 E+04$ & $8.79 \mathrm{E}+03$ & $9.65 \mathrm{E}+03$ & $9.57 \mathrm{E}+03$ & $7.8 \%$ & $<5.1 \mathrm{E}+03$ & $<4.4 \mathrm{E}+03$ & - \\
\hline Cr (IE) & $<3.5 \mathrm{E}+02$ & $<3.6 \mathrm{E}+02$ & $<3.5 \mathrm{E}+02$ & - & - & $<3.9 \mathrm{E}+02$ & $5.16 \mathrm{E}+02$ & $6.40 \mathrm{E}+02$ \\
\hline $\mathrm{Cu}$ (IE) & $1.50 \mathrm{E}+03$ & $1.36 \mathrm{E}+03$ & $1.50 \mathrm{E}+03$ & $1.46 \mathrm{E}+03$ & $5.6 \%$ & $<2.7 \mathrm{E}+01$ & $<2.3 \mathrm{E}+01$ & $3.00 \mathrm{E}+01$ \\
\hline Fe (IE) & $4.93 E+04$ & $6.04 \mathrm{E}+04$ & $6.12 \mathrm{E}+04$ & $5.69 \mathrm{E}+04$ & $12 \%$ & $8.24 \mathrm{E}+02$ & $1.02 \mathrm{E}+05$ & $9.79 \mathrm{E}+04$ \\
\hline Gd (IE) & $2.65 E+02$ & $2.44 \mathrm{E}+02$ & $2.67 \mathrm{E}+02$ & $2.59 \mathrm{E}+02$ & $5.1 \%$ & $<2.2 \mathrm{E}+02$ & $<1.9 \mathrm{E}+02$ & - \\
\hline K (IE) & $<5.6 \mathrm{E}+03$ & $<5.8 \mathrm{E}+03$ & $<5.5 \mathrm{E}+03$ & - & - & $<6.3 \mathrm{E}+03$ & $2.28 \mathrm{E}+04$ & $2.26 \mathrm{E}+04$ \\
\hline La (IE) & $4.31 \mathrm{E}+03$ & $3.75 E+03$ & $4.12 \mathrm{E}+03$ & $4.06 \mathrm{E}+03$ & $7.0 \%$ & $<1.1 \mathrm{E}+03$ & $<9.1 \mathrm{E}+02$ & - \\
\hline Li (IE) & $<6.1 \mathrm{E}+02$ & $<6.4 \mathrm{E}+02$ & $<6.1 \mathrm{E}+02$ & - & - & $<6.9 \mathrm{E}+02$ & $1.64 \mathrm{E}+04$ & $1.49 \mathrm{E}+04$ \\
\hline Mg (IE) & $1.93 \mathrm{E}+02$ & $1.67 \mathrm{E}+02$ & $1.92 \mathrm{E}+02$ & $1.84 \mathrm{E}+02$ & $8.1 \%$ & $<1.3 \mathrm{E}+02$ & $5.32 \mathrm{E}+03$ & $5.20 \mathrm{E}+03$ \\
\hline Mn (IE) & $7.20 \mathrm{E}+04$ & $6.50 \mathrm{E}+04$ & $7.25 \mathrm{E}+04$ & $6.98 E+04$ & $6.0 \%$ & $<1.7 \mathrm{E}+01$ & $1.52 \mathrm{E}+04$ & $1.46 \mathrm{E}+04$ \\
\hline Mo (IE) & $<1.8 \mathrm{E}+03$ & $<1.9 \mathrm{E}+03$ & $<1.8 \mathrm{E}+03$ & - & - & $<2.0 \mathrm{E}+03$ & $<1.7 \mathrm{E}+03$ & - \\
\hline $\mathrm{Na}$ (IE) & $4.44 \mathrm{E}+03$ & $4.71 \mathrm{E}+03$ & $4.91 \mathrm{E}+03$ & $4.69 \mathrm{E}+03$ & $5.1 \%$ & $<2.1 \mathrm{E}+02$ & $8.72 E+04$ & $8.52 E+04$ \\
\hline
\end{tabular}

Divide $\mathrm{mg} / \mathrm{kg}$ values by $1 \mathrm{E}+04$ to convert to wt \% dried solids basis 
WSRC-STI-2007-00192, REV. 1

Table 3-7. Composition of the Aqua Regia Dissolution of Solid Residues from $75{ }^{\circ} \mathrm{C}$ Oxalic Acid Cleaning Test (continued)

\begin{tabular}{|c|c|c|c|c|c|c|c|c|}
\hline Analyte (Method) & $\begin{array}{c}\text { 1st } \\
\text { Replicate } \\
(\mathrm{mg} / \mathrm{kg})\end{array}$ & $\begin{array}{c}\text { 2nd } \\
\text { Replicate } \\
\text { (mg/kg) }\end{array}$ & $\begin{array}{c}\text { 3rd } \\
\text { Replicate } \\
\text { (mg/kg) }\end{array}$ & $\begin{array}{c}\text { Average } \\
\text { (mg/kg) }\end{array}$ & \%RSD & $\begin{array}{c}\text { Blank } \\
\text { (mg/kg) }\end{array}$ & $\begin{array}{c}\text { Avg Analyzed } \\
\text { Glass Std } \\
(\mathrm{mg} / \mathrm{kg})\end{array}$ & \begin{tabular}{|c|} 
Glass Std \\
Composition \\
(mg/kg)
\end{tabular} \\
\hline $\mathrm{Ni}$ (IE) & $1.63 \mathrm{E}+05$ & $1.46 \mathrm{E}+05$ & $1.64 \mathrm{E}+05$ & $1.58 \mathrm{E}+05$ & $6.3 \%$ & $<5.7 \mathrm{E}+02$ & $8.50 \mathrm{E}+03$ & $8.27 E+03$ \\
\hline $\mathrm{P}$ (IE) & $<3.3 \mathrm{E}+03$ & $<3.5 \mathrm{E}+03$ & $<3.3 \mathrm{E}+03$ & - & - & $<3.7 \mathrm{E}+03$ & $<3.2 \mathrm{E}+03$ & $1.10 \mathrm{E}+03$ \\
\hline $\mathrm{Pb}$ (IE) & $<4.3 \mathrm{E}+03$ & $<4.5 \mathrm{E}+03$ & $<4.3 \mathrm{E}+03$ & - & - & $<4.9 \mathrm{E}+03$ & $<4.2 \mathrm{E}+03$ & - \\
\hline S (IE) & $<1.1 \mathrm{E}+03$ & $<1.2 \mathrm{E}+03$ & $<1.1 \mathrm{E}+03$ & - & - & $<1.3 \mathrm{E}+03$ & $<1.1 \mathrm{E}+03$ & - \\
\hline Sb (IE) & $1.55 \mathrm{E}+03$ & $1.24 \mathrm{E}+03$ & $1.30 \mathrm{E}+03$ & $1.37 \mathrm{E}+03$ & $12 \%$ & $<1.2 \mathrm{E}+03$ & $<1.0 \mathrm{E}+03$ & - \\
\hline Si (IE) & $2.38 \mathrm{E}+02$ & $3.08 \mathrm{E}+02$ & $3.51 \mathrm{E}+02$ & $2.99 \mathrm{E}+02$ & $19 \%$ & $<2.3 \mathrm{E}+02$ & $5.56 \mathrm{E}+03$ & $2.24 \mathrm{E}+05$ \\
\hline Sn (IE) & $<9.8 \mathrm{E}+03$ & $<1.0 \mathrm{E}+04$ & $<9.7 \mathrm{E}+03$ & - & - & $<1.1 \mathrm{E}+04$ & $<9.4 \mathrm{E}+03$ & - \\
\hline Sr (IE) & $<6.3 \mathrm{E}+02$ & $<6.5 \mathrm{E}+02$ & $<6.2 \mathrm{E}+02$ & - & - & $<7.0 \mathrm{E}+02$ & $2.05 E+03$ & $3.00 \mathrm{E}+01$ \\
\hline Ti (IE) & $<3.4 \mathrm{E}+01$ & $<3.5 \mathrm{E}+01$ & $<3.4 \mathrm{E}+01$ & - & - & $<3.8 \mathrm{E}+01$ & $6.00 \mathrm{E}+03$ & $6.90 \mathrm{E}+03$ \\
\hline U (IE) & $1.56 \mathrm{E}+03$ & $2.53 \mathrm{E}+03$ & $1.97 \mathrm{E}+03$ & $2.02 \mathrm{E}+03$ & $24 \%$ & $<4.5 \mathrm{E}+02$ & $<3.9 \mathrm{E}+02$ & - \\
\hline $\mathrm{V}$ (IE) & $<1.3 \mathrm{E}+02$ & $<1.3 \mathrm{E}+02$ & $<1.3 \mathrm{E}+02$ & - & - & $<1.4 \mathrm{E}+02$ & $1.24 \mathrm{E}+02$ & - \\
\hline $\mathrm{Zn}$ (IE) & $1.22 \mathrm{E}+03$ & $1.09 \mathrm{E}+03$ & $1.19 \mathrm{E}+03$ & $1.17 \mathrm{E}+03$ & $5.8 \%$ & $<3.0 \mathrm{E}+02$ & $<2.5 \mathrm{E}+02$ & $1.60 \mathrm{E}+02$ \\
\hline Zr (IE) & $2.52 \mathrm{E}+02$ & $2.86 \mathrm{E}+02$ & $3.12 \mathrm{E}+02$ & $2.83 \mathrm{E}+02$ & $11 \%$ & $<7.9 \mathrm{E}+01$ & $7.17 \mathrm{E}+02$ & $9.60 \mathrm{E}+02$ \\
\hline${ }^{233} \mathrm{U}$ (IM) & $<4.5 \mathrm{E}+00$ & $<4.6 \mathrm{E}+00$ & $<4.4 \mathrm{E}+00$ & - & - & $<1.0 \mathrm{E}+00$ & $<8.5 \mathrm{E}-01$ & - \\
\hline${ }^{234} \mathrm{U}$ (IM) & $<4.5 \mathrm{E}+00$ & $<4.6 \mathrm{E}+00$ & $<4.4 \mathrm{E}+00$ & - & - & $<1.0 \mathrm{E}+00$ & $<8.5 \mathrm{E}-01$ & - \\
\hline${ }^{235} \mathrm{U}$ (IM) & $<8.9 \mathrm{E}+00$ & $1.57 \mathrm{E}+01$ & $1.57 \mathrm{E}+01$ & $1.57 \mathrm{E}+01$ & $0.3 \%$ & $<2.0 \mathrm{E}+00$ & $<1.7 \mathrm{E}+00$ & - \\
\hline${ }^{236} \mathrm{U}$ (IM) & $<4.5 \mathrm{E}+00$ & $<4.6 \mathrm{E}+00$ & $<4.4 \mathrm{E}+00$ & - & - & $<1.0 \mathrm{E}+00$ & $<8.5 \mathrm{E}-01$ & - \\
\hline${ }^{238} \mathrm{U}$ (IM) & $1.34 \mathrm{E}+03$ & $2.78 \mathrm{E}+03$ & $2.30 \mathrm{E}+03$ & $2.14 \mathrm{E}+03$ & $34 \%$ & $<1.3 \mathrm{E}+01$ & $<1.1 \mathrm{E}+01$ & - \\
\hline U total (IM) & $1.34 \mathrm{E}+03$ & $2.80 \mathrm{E}+03$ & $2.31 \mathrm{E}+03$ & $2.15 E+03$ & $35 \%$ & $<1.8 \mathrm{E}+01$ & $<1.5 \mathrm{E}+01$ & - \\
\hline
\end{tabular}

Divide $\mathrm{mg} / \mathrm{kg}$ values by $1 \mathrm{E}+04$ to convert to wt \% dried solids basis 
Table 3-7. Composition of the Aqua Regia Dissolution of Solid Residues from $75{ }^{\circ} \mathrm{C}$ Oxalic Acid Cleaning Test (continued)

\begin{tabular}{|l|c|c|c|c|c|c|c|}
\hline & $\begin{array}{c}\text { 1st } \\
\text { Replicate } \\
\text { AnCi/kg) }\end{array}$ & $\begin{array}{c}\text { 2nd } \\
\text { Replicate } \\
\text { (mCi/kg) }\end{array}$ & $\begin{array}{c}\text { 3rd } \\
\text { Replicate } \\
\text { (mCi/kg) }\end{array}$ & $\begin{array}{c}\text { Average } \\
\text { (mCi/kg) }\end{array}$ & \%RSD & $\begin{array}{c}\text { Avg Analyzed } \\
\text { Blank } \\
\text { (mCi/kg) }\end{array}$ & $\begin{array}{c}\text { Glass Std } \\
\text { Glass Std } \\
\text { Composition } \\
\text { (mCi/kg) }\end{array}$ \\
\hline${ }^{99} \mathrm{Tc}(\mathrm{mL} / \mathbf{k g})$
\end{tabular}

a - No yield was obtained for ${ }^{237} \mathrm{~Np}$ on the blank and standard and a lower limit on the concentration could not be provided. 
Table 3-8. Composition of the Oxalic Acid Filtrate from the $50{ }^{\circ} \mathrm{C}$ Oxalic Acid Cleaning Test

\begin{tabular}{|c|c|c|c|c|c|c|}
\hline Analyte & $\begin{array}{c}\text { 1st } \\
\text { Replicate } \\
\text { (mg/L) }\end{array}$ & $\begin{array}{c}\text { 2nd } \\
\text { Replicate } \\
\text { (mg/L) }\end{array}$ & $\begin{array}{c}\text { 3rd } \\
\text { Replicate } \\
\text { (mg/L) }\end{array}$ & $\begin{array}{c}\text { Average } \\
\text { (mg/L) }\end{array}$ & \%RSD & $\begin{array}{c}\text { Blank } \\
(\mathrm{mg} / \mathrm{L})\end{array}$ \\
\hline Ag (IE) & $3.46 \mathrm{E}+00$ & $3.46 \mathrm{E}+00$ & $3.49 \mathrm{E}+00$ & $3.47 \mathrm{E}+00$ & $0.5 \%$ & $<8.5 \mathrm{E}-01$ \\
\hline $\mathrm{Al}$ (IE) & $2.33 \mathrm{E}+02$ & $2.45 \mathrm{E}+02$ & $2.52 \mathrm{E}+02$ & $2.43 \mathrm{E}+02$ & $3.9 \%$ & $<1.2 \mathrm{E}+00$ \\
\hline B (IE) & $<1.9 \mathrm{E}+00$ & $<1.9 \mathrm{E}+00$ & $<1.9 \mathrm{E}+00$ & - & - & $<1.9 \mathrm{E}+00$ \\
\hline $\mathrm{Ba}$ (IE) & $2.33 \mathrm{E}+01$ & $2.29 E+01$ & $2.32 \mathrm{E}+01$ & $2.31 \mathrm{E}+01$ & $0.8 \%$ & $<1.0 \mathrm{E}+00$ \\
\hline Ca (IE) & $4.78 \mathrm{E}+01$ & $4.80 \mathrm{E}+01$ & $4.85 \mathrm{E}+01$ & $4.81 \mathrm{E}+01$ & $0.8 \%$ & $<1.1 \mathrm{E}+00$ \\
\hline Cd (IE) & 6.14E-01 & 4.29E-01 & 5.35E-01 & 5.26E-01 & $18 \%$ & $<3.9 \mathrm{E}-01$ \\
\hline Ce (IE) & $<2.5 \mathrm{E}+01$ & $<2.6 \mathrm{E}+01$ & $<2.5 \mathrm{E}+01$ & - & - & $<2.6 \mathrm{E}+01$ \\
\hline Cr (IE) & $4.28 \mathrm{E}+00$ & $4.74 \mathrm{E}+00$ & $3.91 \mathrm{E}+00$ & $4.31 \mathrm{E}+00$ & $9.7 \%$ & $<2.0 \mathrm{E}+00$ \\
\hline $\mathrm{Cu}$ (IE) & 1.45E-01 & $<1.4 \mathrm{E}-01$ & $<1.4 \mathrm{E}-01$ & - & - & $<1.4 \mathrm{E}-01$ \\
\hline Fe (IE) & $3.75 \mathrm{E}+03$ & $3.73 E+03$ & $3.72 \mathrm{E}+03$ & $3.73 E+03$ & $0.5 \%$ & $<2.9 \mathrm{E}-01$ \\
\hline Gd (IE) & $4.52 \mathrm{E}+00$ & $4.53 \mathrm{E}+00$ & $4.52 \mathrm{E}+00$ & $4.52 \mathrm{E}+00$ & $0.2 \%$ & $<1.1 \mathrm{E}+00$ \\
\hline K (IE) & $<3.1 \mathrm{E}+01$ & $3.24 \mathrm{E}+01$ & $3.32 \mathrm{E}+01$ & $3.28 \mathrm{E}+01$ & $1.7 \%$ & $<3.2 \mathrm{E}+01$ \\
\hline La (IE) & $<5.3 \mathrm{E}+00$ & $<5.4 \mathrm{E}+00$ & $<5.4 \mathrm{E}+00$ & - & - & $<5.4 \mathrm{E}+00$ \\
\hline Li (IE) & $6.29 \mathrm{E}+00$ & $6.51 \mathrm{E}+00$ & $6.25 \mathrm{E}+00$ & $6.35 \mathrm{E}+00$ & $2.3 \%$ & $<3.5 \mathrm{E}+00$ \\
\hline Mg (IE) & $4.86 \mathrm{E}+00$ & $4.81 \mathrm{E}+00$ & $4.80 \mathrm{E}+00$ & $4.82 \mathrm{E}+00$ & $0.6 \%$ & $<6.4 \mathrm{E}-01$ \\
\hline Mn (IE) & $4.48 \mathrm{E}+02$ & $4.38 \mathrm{E}+02$ & 4.37E+02 & $4.41 \mathrm{E}+02$ & $1.3 \%$ & $<8.6 \mathrm{E}-02$ \\
\hline Mo (IE) & $1.95 \mathrm{E}+01$ & $1.99 \mathrm{E}+01$ & $1.85 \mathrm{E}+01$ & $1.93 \mathrm{E}+01$ & $4.0 \%$ & $<1.0 \mathrm{E}+01$ \\
\hline $\mathrm{Na}$ (IE) & $2.21 \mathrm{E}+03$ & $2.24 \mathrm{E}+03$ & $2.26 \mathrm{E}+03$ & $2.23 \mathrm{E}+03$ & $1.1 \%$ & $<1.0 \mathrm{E}+00$ \\
\hline $\mathrm{Ni}$ (IE) & $<2.8 \mathrm{E}+00$ & $<2.9 \mathrm{E}+00$ & $<2.8 \mathrm{E}+00$ & - & - & $<2.9 \mathrm{E}+00$ \\
\hline $\mathrm{P}$ (IE) & $<1.9 \mathrm{E}+01$ & $<1.9 \mathrm{E}+01$ & $<1.9 \mathrm{E}+01$ & - & - & $<1.9 \mathrm{E}+01$ \\
\hline $\mathrm{Pb}$ (IE) & $<2.4 \mathrm{E}+01$ & $<2.5 \mathrm{E}+01$ & $<2.4 \mathrm{E}+01$ & - & - & $<2.5 \mathrm{E}+01$ \\
\hline S (IE) & $2.93 \mathrm{E}+01$ & $2.64 \mathrm{E}+01$ & $2.83 \mathrm{E}+01$ & $2.80 \mathrm{E}+01$ & $5.3 \%$ & $<6.5 \mathrm{E}+00$ \\
\hline Sb (IE) & $1.81 \mathrm{E}+01$ & $1.75 \mathrm{E}+01$ & $1.69 \mathrm{E}+01$ & $1.75 \mathrm{E}+01$ & $3.3 \%$ & $<6.1 \mathrm{E}+00$ \\
\hline Si (IE) & $1.44 \mathrm{E}+02$ & $1.44 \mathrm{E}+02$ & $1.44 \mathrm{E}+02$ & $1.44 \mathrm{E}+02$ & $0.1 \%$ & $<1.2 \mathrm{E}+00$ \\
\hline Sn (IE) & $6.24 \mathrm{E}+01$ & $6.41 \mathrm{E}+01$ & $5.55 \mathrm{E}+01$ & $6.07 \mathrm{E}+01$ & $7.5 \%$ & $<5.6 \mathrm{E}+01$ \\
\hline Sr (IE) & $1.64 \mathrm{E}+01$ & $1.68 \mathrm{E}+01$ & $1.70 \mathrm{E}+01$ & $1.67 \mathrm{E}+01$ & $1.8 \%$ & $<3.6 \mathrm{E}+00$ \\
\hline
\end{tabular}


Table 3-8. Composition of the Oxalic Acid Filtrate from the $50{ }^{\circ} \mathrm{C}$ Oxalic Acid Cleaning Test (continued)

\begin{tabular}{|l|c|c|c|c|c|c|}
\hline Analyte & $\begin{array}{c}\text { 1st } \\
\text { Replicate } \\
(\mathbf{m g} / \mathbf{L})\end{array}$ & $\begin{array}{c}\text { 2nd } \\
\text { Replicate } \\
\text { (mg/L) }\end{array}$ & $\begin{array}{c}\text { 3rd } \\
\text { Replicate } \\
\text { (mg/L) }\end{array}$ & $\begin{array}{c}\text { Average } \\
\text { (mg/L) }\end{array}$ & \%RSD & $\begin{array}{c}\text { Blank } \\
\text { (mg/L) }\end{array}$ \\
\hline Ti (IE) & $3.00 \mathrm{E}+00$ & $2.97 \mathrm{E}+00$ & $2.99 \mathrm{E}+00$ & $2.99 \mathrm{E}+00$ & $0.6 \%$ & $<1.9 \mathrm{E}-01$ \\
\hline $\mathrm{U}(\mathrm{IE})$ & $1.29 \mathrm{E}+03$ & $1.27 \mathrm{E}+03$ & $1.22 \mathrm{E}+03$ & $1.26 \mathrm{E}+03$ & $3.2 \%$ & $<2.3 \mathrm{E}+00$ \\
\hline $\mathrm{V}(\mathrm{IE})$ & $2.16 \mathrm{E}+01$ & $2.14 \mathrm{E}+01$ & $1.96 \mathrm{E}+01$ & $2.08 \mathrm{E}+01$ & $5.3 \%$ & $<7.2 \mathrm{E}-01$ \\
\hline $\mathrm{Zn}(\mathrm{IE})$ & $<1.5 \mathrm{E}+00$ & $<1.5 \mathrm{E}+00$ & $<1.5 \mathrm{E}+00$ & - & - & $<1.5 \mathrm{E}+00$ \\
\hline $\mathrm{Zr}(\mathrm{IE})$ & $5.34 \mathrm{E}+01$ & $5.35 \mathrm{E}+01$ & $5.35 \mathrm{E}+01$ & $5.35 \mathrm{E}+01$ & $0.1 \%$ & $<4.0 \mathrm{E}-01$ \\
\hline${ }^{233} \mathrm{U}(\mathrm{IM})$ & $<1.0 \mathrm{E}+00$ & $<1.0 \mathrm{E}+00$ & $<1.0 \mathrm{E}+00$ & - & - & $<5.1 \mathrm{E}-03$ \\
\hline${ }^{234} \mathrm{U}(\mathrm{IM})$ & $<1.0 \mathrm{E}+00$ & $<1.0 \mathrm{E}+00$ & $<1.0 \mathrm{E}+00$ & - & - & $<5.1 \mathrm{E}-03$ \\
\hline${ }^{235} \mathrm{U}(\mathrm{IM})$ & $7.05 \mathrm{E}+00$ & $8.01 \mathrm{E}+00$ & $6.49 \mathrm{E}+00$ & $7.19 \mathrm{E}+00$ & $11 \%$ & $<1.0 \mathrm{E}-02$ \\
\hline${ }^{236} \mathrm{U}(\mathrm{IM})$ & $<1.0 \mathrm{E}+00$ & $<1.0 \mathrm{E}+00$ & $<1.0 \mathrm{E}+00$ & - & - & $<5.1 \mathrm{E}-03$ \\
\hline${ }^{238} \mathrm{U}(\mathrm{IM})$ & $1.23 \mathrm{E}+03$ & $1.20 \mathrm{E}+03$ & $1.18 \mathrm{E}+03$ & $1.20 \mathrm{E}+03$ & $2 \%$ & $<6.6 \mathrm{E}-02$ \\
\hline $\mathrm{U}$ total (IM) & $1.24 \mathrm{E}+03$ & $1.21 \mathrm{E}+03$ & $1.18 \mathrm{E}+03$ & $1.21 \mathrm{E}+03$ & $2 \%$ & $<9.1 \mathrm{E}-02$ \\
\hline
\end{tabular}

Table 3-8. Composition of the Oxalic Acid Filtrate from the $50{ }^{\circ} \mathrm{C}$ Oxalic Acid Cleaning Test (continued)

\begin{tabular}{|l|c|c|c|c|c|c|}
\hline Analyte & $\begin{array}{c}\text { 1st } \\
\text { Replicate } \\
\text { (mCi/L) }\end{array}$ & $\begin{array}{c}\text { 2nd } \\
\text { Replicate } \\
\text { (mCi/L) }\end{array}$ & $\begin{array}{c}\text { 3rd } \\
\text { Replicate } \\
\text { (mCi/L) }\end{array}$ & $\begin{array}{c}\text { Average } \\
\text { (mCi/L) }\end{array}$ & \%RSD & $\begin{array}{c}\text { Blank } \\
\text { (mCi/L) }\end{array}$ \\
\hline${ }^{99} \mathrm{Tc}(\mathrm{SL})$ & $<4.0 \mathrm{E}-04$ & $<4.2 \mathrm{E}-04$ & $<5.2 \mathrm{E}-04$ & - & - & $<2.3 \mathrm{E}-05$ \\
\hline${ }^{237} \mathrm{~Np}(\mathrm{IM})$ & $<1.1 \mathrm{E}-03$ & $<1.1 \mathrm{E}-03$ & $<1.1 \mathrm{E}-03$ & - & - & $<5.4 \mathrm{E}-06$ \\
\hline${ }^{238} \mathrm{Pu}(\mathrm{SA})$ & $1.53 \mathrm{E}-03$ & $2.73 \mathrm{E}-04$ & $9.75 \mathrm{E}-04$ & $9.25 \mathrm{E}-04$ & $68 \%$ & $<3.2 \mathrm{E}-05$ \\
\hline${ }^{239 / 240} \mathrm{Pu}(\mathrm{SA})$ & $7.62 \mathrm{E}-03$ & $1.26 \mathrm{E}-03$ & $4.35 \mathrm{E}-03$ & $4.41 \mathrm{E}-03$ & $72 \%$ & $<3.7 \mathrm{E}-05$ \\
\hline${ }^{241} \mathrm{Pu}(\mathrm{SA})$ & $<2.6 \mathrm{E}-03$ & $<5.0 \mathrm{E}-04$ & $<1.8 \mathrm{E}-03$ & - & - & $<7.0 \mathrm{E}-04$ \\
\hline
\end{tabular}


Table 3-9. Composition of the Oxalic Acid Filtrate from the $75^{\circ} \mathrm{C}$ Oxalic Acid Cleaning Test

\begin{tabular}{|l|c|c|c|c|c|c|}
\hline Analyte & $\begin{array}{c}\text { 1st } \\
\text { Replicate } \\
\text { (mg/L) }\end{array}$ & $\begin{array}{c}\text { 2nd } \\
\text { Replicate } \\
\text { (mg/L) }\end{array}$ & $\begin{array}{c}\text { 3rd } \\
\text { Replicate } \\
\text { (mg/L) }\end{array}$ & $\begin{array}{c}\text { Average } \\
\text { (mg/L) }\end{array}$ & \%RSD & $\begin{array}{c}\text { Blank } \\
\text { (mg/L) }\end{array}$ \\
\hline Ag (IE) & $4.03 \mathrm{E}+00$ & $4.00 \mathrm{E}+00$ & $4.06 \mathrm{E}+00$ & $4.03 \mathrm{E}+00$ & $0.8 \%$ & $<8.4 \mathrm{E}-01$ \\
\hline $\mathrm{Al}(\mathrm{IE})$ & $3.25 \mathrm{E}+02$ & $3.00 \mathrm{E}+02$ & $3.20 \mathrm{E}+02$ & $3.15 \mathrm{E}+02$ & $4.2 \%$ & $4.00 \mathrm{E}+00$ \\
\hline Ba (IE) & $2.62 \mathrm{E}+01$ & $2.60 \mathrm{E}+01$ & $2.62 \mathrm{E}+01$ & $2.61 \mathrm{E}+01$ & $0.5 \%$ & $<1.0 \mathrm{E}+00$ \\
\hline Cd (IE) & $1.19 \mathrm{E}+00$ & $8.15 \mathrm{E}-01$ & $1.02 \mathrm{E}+00$ & $1.01 \mathrm{E}+00$ & $19 \%$ & $<3.9 \mathrm{E}-01$ \\
\hline Cr (IE) & $6.46 \mathrm{E}+00$ & $4.98 \mathrm{E}+00$ & $5.45 \mathrm{E}+00$ & $5.63 \mathrm{E}+00$ & $14 \%$ & $<2.0 \mathrm{E}+00$ \\
\hline Fe (IE) & $4.70 \mathrm{E}+03$ & $4.62 \mathrm{E}+03$ & $4.65 \mathrm{E}+03$ & $4.66 \mathrm{E}+03$ & $0.9 \%$ & $4.10 \mathrm{E}+00$ \\
\hline $\mathrm{Mn}(\mathrm{IE})$ & $6.66 \mathrm{E}+02$ & $6.60 \mathrm{E}+02$ & $6.65 \mathrm{E}+02$ & $6.64 \mathrm{E}+02$ & $0.5 \%$ & $<8.6 \mathrm{E}-02$ \\
\hline $\mathrm{Ni}(\mathrm{IE})$ & $<2.9 \mathrm{E}+00$ & $<2.8 \mathrm{E}+00$ & $<2.8 \mathrm{E}+00$ & - & - & $<2.9 \mathrm{E}+00$ \\
\hline $\mathrm{Pb}(\mathrm{IE})$ & $<2.4 \mathrm{E}+01$ & $<2.4 \mathrm{E}+01$ & $<2.4 \mathrm{E}+01$ & - & - & $<2.5 \mathrm{E}+01$ \\
\hline U (IE) & $1.54 \mathrm{E}+03$ & $1.49 \mathrm{E}+03$ & $1.50 \mathrm{E}+03$ & $1.51 \mathrm{E}+03$ & $1.9 \%$ & $<2.3 \mathrm{E}+00$ \\
\hline${ }^{233} \mathrm{U}(\mathrm{IM})$ & $<1.0 \mathrm{E}+00$ & $<1.0 \mathrm{E}+00$ & $<1.0 \mathrm{E}+00$ & - & - & $<5.0 \mathrm{E}-03$ \\
\hline${ }^{234} \mathrm{U}(\mathrm{IM})$ & $<3.0 \mathrm{E}+00$ & $<3.0 \mathrm{E}+00$ & $<3.0 \mathrm{E}+00$ & - & - & $<1.5 \mathrm{E}-02$ \\
\hline${ }^{235} \mathrm{U}(\mathrm{IM})$ & $1.07 \mathrm{E}+01$ & $1.06 \mathrm{E}+01$ & $1.01 \mathrm{E}+01$ & $1.05 \mathrm{E}+01$ & $3.3 \%$ & $<7.6 \mathrm{E}-03$ \\
\hline${ }^{236} \mathrm{U}(\mathrm{IM})$ & $<1.5 \mathrm{E}+00$ & $<1.5 \mathrm{E}+00$ & $<1.5 \mathrm{E}+00$ & - & - & $<7.6 \mathrm{E}-03$ \\
\hline${ }^{238} \mathrm{U}(\mathrm{IM})$ & $1.53 \mathrm{E}+03$ & $1.53 \mathrm{E}+03$ & $1.55 \mathrm{E}+03$ & $1.54 \mathrm{E}+03$ & $0.7 \%$ & $<5.0 \mathrm{E}-02$ \\
\hline $\mathrm{U}$ total (IM) & $1.54 \mathrm{E}+03$ & $1.54 \mathrm{E}+03$ & $1.56 \mathrm{E}+03$ & $1.55 \mathrm{E}+03$ & $0.7 \%$ & $<8.6 \mathrm{E}-02$ \\
\hline
\end{tabular}

Table 3-9. Composition of the Oxalic Acid Filtrate from the $75^{\circ} \mathrm{C}$ Oxalic Acid Cleaning Test (continued)

\begin{tabular}{|l|c|c|c|c|c|c|}
\hline Analyte & $\begin{array}{c}\text { 1st } \\
\text { Replicate } \\
\text { (mCi/L) }\end{array}$ & $\begin{array}{c}\text { 2nd } \\
\text { Replicate } \\
\text { (mCi/L) }\end{array}$ & $\begin{array}{c}\text { 3rd } \\
\text { Replicate } \\
\text { (mCi/L) }\end{array}$ & $\begin{array}{c}\text { Average } \\
\text { (mCi/L) }\end{array}$ & \%RSD & $\begin{array}{c}\text { Blank } \\
\text { (mCi/L) }\end{array}$ \\
\hline${ }^{99} \mathrm{Tc}(\mathrm{SL})$ & $<4.2 \mathrm{E}-04$ & $<4.8 \mathrm{E}-04$ & $<3.4 \mathrm{E}-04$ & - & - & $<1.7 \mathrm{E}-05$ \\
\hline${ }^{237} \mathrm{~Np}(\mathrm{IM})$ & $<1.1 \mathrm{E}-03$ & $1.16 \mathrm{E}-03$ & $<1.1 \mathrm{E}-03$ & $1.16 \mathrm{E}-03 * *$ & - & $<5.3 \mathrm{E}-06$ \\
\hline${ }^{238} \mathrm{Pu}(\mathrm{SA})$ & $9.39 \mathrm{E}-04$ & $9.39 \mathrm{E}-04$ & $*$ & $9.39 \mathrm{E}-04$ & $0.1 \%$ & $<2.2 \mathrm{E}-05$ \\
\hline${ }^{239 / 240} \mathrm{Pu} \mathrm{(SA)}$ & $3.97 \mathrm{E}-03$ & $4.14 \mathrm{E}-03$ & $*$ & $4.06 \mathrm{E}-03$ & $3.0 \%$ & $<5.6 \mathrm{E}-05$ \\
\hline${ }^{241} \mathrm{Pu}(\mathrm{SA})$ & $<1.2 \mathrm{E}-03$ & $<1.3 \mathrm{E}-03$ & $*$ & $<1.3 \mathrm{E}-03$ & - & $<3.6 \mathrm{E}-04$ \\
\hline
\end{tabular}

* Incomplete separation so the sample could not be counted.

** Only one value out of the three replicates was above the detection limit. 
Table 3-10. Composition of the Aqua Regia Dissolution of Solid Residues from $50{ }^{\circ} \mathrm{C}$ Neutralization Test

\begin{tabular}{|c|c|c|c|c|c|c|c|c|}
\hline Analyte (Method) & $\begin{array}{c}\text { 1st } \\
\text { Replicate } \\
\text { (mg/kg) }\end{array}$ & $\begin{array}{c}\text { 2nd } \\
\text { Replicate } \\
\text { (mg/kg) }\end{array}$ & $\begin{array}{c}\text { 3rd } \\
\text { Replicate } \\
\text { (mg/kg) }\end{array}$ & $\begin{array}{c}\text { Average } \\
\text { (mg/kg) }\end{array}$ & $\%$ RSD & $\begin{array}{c}\text { Blank } \\
\text { (mg/kg) }\end{array}$ & \begin{tabular}{|c|} 
Avg Analyzed \\
Glass Std \\
(mg/kg)
\end{tabular} & $\begin{array}{c}\text { Glass Std } \\
\text { Composition } \\
\text { (mg/kg) }\end{array}$ \\
\hline Ag (IE) & $<1.7 \mathrm{E}+02$ & $<1.7 \mathrm{E}+02$ & $<1.7 \mathrm{E}+02$ & - & - & $<1.7 \mathrm{E}+02$ & $<1.7 \mathrm{E}+02$ & - \\
\hline $\mathrm{Al}$ (IE) & $4.31 \mathrm{E}+04$ & $4.39 \mathrm{E}+04$ & $3.23 \mathrm{E}+04$ & $3.98 \mathrm{E}+04$ & $16 \%$ & $<2.4 \mathrm{E}+02$ & $2.23 \mathrm{E}+04$ & $2.50 \mathrm{E}+04$ \\
\hline Ba (IE) & $2.15 E+02$ & $2.38 \mathrm{E}+02$ & $<2.0 \mathrm{E}+02$ & $2.26 \mathrm{E}+02$ & $7.3 \%$ & $<2.1 \mathrm{E}+02$ & $7.01 \mathrm{E}+02$ & $7.90 \mathrm{E}+02$ \\
\hline Cd (IE) & $<7.7 \mathrm{E}+01$ & $<7.6 \mathrm{E}+01$ & $<7.6 \mathrm{E}+01$ & - & - & $<7.7 \mathrm{E}+01$ & $<7.8 \mathrm{E}+01$ & - \\
\hline Cr (IE) & $<3.9 \mathrm{E}+02$ & $<3.9 \mathrm{E}+02$ & $<3.9 \mathrm{E}+02$ & - & - & $<3.9 \mathrm{E}+02$ & $5.84 \mathrm{E}+02$ & $6.40 \mathrm{E}+02$ \\
\hline Fe (IE) & $5.63 \mathrm{E}+04$ & $5.68 \mathrm{E}+04$ & $4.31 \mathrm{E}+04$ & $5.21 \mathrm{E}+04$ & $15 \%$ & $<5.8 \mathrm{E}+01$ & $9.90 \mathrm{E}+04$ & $9.79 \mathrm{E}+04$ \\
\hline Mn (IE) & $6.95 \mathrm{E}+03$ & $7.06 \mathrm{E}+03$ & $5.32 \mathrm{E}+03$ & $6.44 \mathrm{E}+03$ & $15 \%$ & $<1.7 \mathrm{E}+01$ & $1.46 \mathrm{E}+04$ & $1.46 \mathrm{E}+04$ \\
\hline $\mathrm{Ni}$ (IE) & $<5.7 \mathrm{E}+02$ & $<5.6 \mathrm{E}+02$ & $<5.6 \mathrm{E}+02$ & - & - & $<5.7 \mathrm{E}+02$ & $8.19 \mathrm{E}+03$ & $8.27 \mathrm{E}+03$ \\
\hline $\mathrm{Pb}$ (IE) & $<4.9 \mathrm{E}+03$ & $<4.8 \mathrm{E}+03$ & $<4.8 \mathrm{E}+03$ & - & - & $<4.9 \mathrm{E}+03$ & $<4.9 \mathrm{E}+03$ & - \\
\hline $\mathrm{U}$ (IE) & $1.88 \mathrm{E}+04$ & $1.88 \mathrm{E}+04$ & $1.41 \mathrm{E}+04$ & $1.72 \mathrm{E}+04$ & $16 \%$ & $<4.5 \mathrm{E}+02$ & $<4.6 \mathrm{E}+02$ & - \\
\hline${ }^{233} \mathrm{U}(\mathrm{IM})$ & $<7.5 \mathrm{E}+00$ & $<7.4 \mathrm{E}+00$ & $<7.4 \mathrm{E}+00$ & - & - & $<1.5 \mathrm{E}+00$ & $<3.8 \mathrm{E}-01$ & - \\
\hline${ }^{234} \mathrm{U}$ (IM) & $<1.5 \mathrm{E}+01$ & $<1.5 \mathrm{E}+01$ & $<1.5 \mathrm{E}+01$ & - & - & $<3.0 \mathrm{E}+00$ & $<7.6 \mathrm{E}-01$ & - \\
\hline${ }^{235} \mathrm{U}$ (IM) & $1.23 \mathrm{E}+02$ & $1.36 \mathrm{E}+02$ & $1.08 \mathrm{E}+02$ & $1.22 \mathrm{E}+02$ & $11 \%$ & $<2.0 \mathrm{E}+00$ & $<5.0 \mathrm{E}-01$ & - \\
\hline${ }^{236} \mathrm{U}$ (IM) & $<1.0 \mathrm{E}+01$ & $<9.9 \mathrm{E}+00$ & $<9.9 \mathrm{E}+00$ & - & - & $<2.0 \mathrm{E}+00$ & $<5.0 \mathrm{E}-01$ & - \\
\hline${ }^{238} \mathrm{U}$ (IM) & $1.83 E+04$ & $1.89 \mathrm{E}+04$ & $1.43 E+04$ & $1.72 \mathrm{E}+04$ & $15 \%$ & $<1.5 \mathrm{E}+01$ & $6.00 \mathrm{E}+00$ & - \\
\hline U total (IM) & $1.84 \mathrm{E}+04$ & $1.90 \mathrm{E}+04$ & $1.44 \mathrm{E}+04$ & $1.73 \mathrm{E}+04$ & $15 \%$ & $<2.3 \mathrm{E}+01$ & $6.00 \mathrm{E}+00$ & - \\
\hline
\end{tabular}

Divide $\mathrm{mg} / \mathrm{kg}$ values by $1 \mathrm{E}+04$ to convert to wt \% dried solids basis 
Table 3-11. Composition of the Aqua Regia Dissolution of Solid Residues from $75{ }^{\circ} \mathrm{C}$ Neutralization Test

\begin{tabular}{|c|c|c|c|c|c|c|c|c|}
\hline Analyte (Method) & $\begin{array}{c}\text { 1st } \\
\text { Replicate } \\
\text { (mg/kg) }\end{array}$ & $\begin{array}{c}\text { 2nd } \\
\text { Replicate } \\
\text { (mg/kg) }\end{array}$ & $\begin{array}{c}\text { 3rd } \\
\text { Replicate } \\
\text { (mg/kg) }\end{array}$ & $\begin{array}{c}\text { Average } \\
\text { (mg/kg) }\end{array}$ & $\%$ RSD & $\begin{array}{c}\text { Blank } \\
\text { (mg/kg) }\end{array}$ & \begin{tabular}{|c|} 
Avg Analyzed \\
Glass Std \\
(mg/kg)
\end{tabular} & $\begin{array}{c}\text { Glass Std } \\
\text { Composition } \\
\text { (mg/kg) }\end{array}$ \\
\hline Ag (IE) & $<1.6 \mathrm{E}+02$ & $<1.7 \mathrm{E}+02$ & $<1.7 \mathrm{E}+02$ & - & - & $<1.7 \mathrm{E}+02$ & $<1.7 \mathrm{E}+02$ & - \\
\hline $\mathrm{Al}$ (IE) & $7.68 \mathrm{E}+03$ & $7.86 \mathrm{E}+03$ & $8.49 \mathrm{E}+03$ & $8.01 \mathrm{E}+03$ & $5.3 \%$ & $<2.4 \mathrm{E}+02$ & $2.22 \mathrm{E}+04$ & $2.50 \mathrm{E}+04$ \\
\hline Ba (IE) & $<2.0 \mathrm{E}+02$ & $<2.1 \mathrm{E}+02$ & $<2.1 \mathrm{E}+02$ & - & - & $<2.1 \mathrm{E}+02$ & $6.97 \mathrm{E}+02$ & $7.90 \mathrm{E}+02$ \\
\hline Cd (IE) & $<7.6 \mathrm{E}+01$ & $<7.7 \mathrm{E}+01$ & $<7.8 \mathrm{E}+01$ & - & - & $<7.7 \mathrm{E}+01$ & $<7.9 \mathrm{E}+01$ & - \\
\hline Cr (IE) & $<3.9 \mathrm{E}+02$ & $<3.9 \mathrm{E}+02$ & $<4.0 \mathrm{E}+02$ & - & - & $<3.9 \mathrm{E}+02$ & $6.16 \mathrm{E}+02$ & $6.40 \mathrm{E}+02$ \\
\hline Fe (IE) & $4.45 \mathrm{E}+04$ & $4.50 \mathrm{E}+04$ & $4.68 \mathrm{E}+04$ & $4.54 \mathrm{E}+04$ & $2.6 \%$ & $1.02 \mathrm{E}+02$ & $9.87 \mathrm{E}+04$ & $9.79 \mathrm{E}+04$ \\
\hline Mn (IE) & $6.75 \mathrm{E}+03$ & $6.75 \mathrm{E}+03$ & $7.08 \mathrm{E}+03$ & $6.86 \mathrm{E}+03$ & $2.7 \%$ & $<1.7 \mathrm{E}+01$ & $1.45 \mathrm{E}+04$ & $1.46 \mathrm{E}+04$ \\
\hline $\mathrm{Ni}$ (IE) & $<5.6 \mathrm{E}+02$ & $<5.7 \mathrm{E}+02$ & $<5.7 \mathrm{E}+02$ & - & - & $<5.7 \mathrm{E}+02$ & $8.09 \mathrm{E}+03$ & $8.27 \mathrm{E}+03$ \\
\hline $\mathrm{Pb}$ (IE) & $<4.8 \mathrm{E}+03$ & $<4.9 \mathrm{E}+03$ & $<4.9 \mathrm{E}+03$ & - & - & $<4.9 \mathrm{E}+03$ & $<5.0 \mathrm{E}+03$ & - \\
\hline $\mathrm{U}$ (IE) & $1.35 \mathrm{E}+04$ & $1.35 \mathrm{E}+04$ & $1.45 \mathrm{E}+04$ & $1.38 \mathrm{E}+04$ & $4.2 \%$ & $<4.5 \mathrm{E}+02$ & $<4.6 \mathrm{E}+02$ & - \\
\hline${ }^{233} \mathrm{U}(\mathrm{IM})$ & $<1.0 \mathrm{E}+01$ & $<9.9 \mathrm{E}+00$ & $<9.9 \mathrm{E}+00$ & - & - & $<2.0 \mathrm{E}+00$ & $<5.0 \mathrm{E}-01$ & - \\
\hline${ }^{234} \mathrm{U}$ (IM) & $<5.0 \mathrm{E}+00$ & $<5.0 \mathrm{E}+00$ & $<5.0 \mathrm{E}+00$ & - & - & $<1.0 \mathrm{E}+00$ & $<2.5 \mathrm{E}-01$ & - \\
\hline${ }^{235} \mathrm{U}$ (IM) & $9.15 \mathrm{E}+01$ & $8.64 \mathrm{E}+01$ & $9.73 E+01$ & $9.17 \mathrm{E}+01$ & $6.0 \%$ & $<1.5 \mathrm{E}+00$ & $<3.8 \mathrm{E}-01$ & - \\
\hline${ }^{236} \mathrm{U}$ (IM) & $<2.0 \mathrm{E}+01$ & $<2.0 \mathrm{E}+01$ & $<2.0 \mathrm{E}+01$ & - & - & $<4.0 \mathrm{E}+00$ & $<1.0 \mathrm{E}+00$ & - \\
\hline${ }^{238} \mathrm{U}$ (IM) & $1.40 \mathrm{E}+04$ & $1.36 \mathrm{E}+04$ & $1.43 \mathrm{E}+04$ & $1.39 \mathrm{E}+04$ & $2.7 \%$ & $<1.1 \mathrm{E}+01$ & $7.82 \mathrm{E}+00$ & - \\
\hline U total (IM) & $1.41 \mathrm{E}+04$ & $1.36 \mathrm{E}+04$ & $1.44 \mathrm{E}+04$ & $1.40 \mathrm{E}+04$ & $2.7 \%$ & $<1.9 \mathrm{E}+01$ & $7.82 \mathrm{E}+00$ & - \\
\hline
\end{tabular}

Divide $\mathrm{mg} / \mathrm{kg}$ values by $1 \mathrm{E}+04$ to convert to wt \% dried solids basis 
Table 3-12. Composition of the Filtrate from the $50{ }^{\circ} \mathrm{C}$ Neutralization Test

\begin{tabular}{|c|c|c|c|c|c|}
\hline Analyte & $\begin{array}{c}\text { 1st } \\
\text { Replicate } \\
\text { (mg/L) }\end{array}$ & $\begin{array}{c}\text { 2nd } \\
\text { Replicate } \\
\text { (mg/L) }\end{array}$ & $\begin{array}{c}\text { 3rd } \\
\text { Replicate } \\
\text { (mg/L) }\end{array}$ & $\begin{array}{c}\text { Average } \\
\text { (mg/L) }\end{array}$ & \%RSD \\
\hline Ag (IE) & $<1.7 \mathrm{E}-01$ & $<1.7 \mathrm{E}-01$ & $<1.7 \mathrm{E}-01$ & - & - \\
\hline Al (IE) & $2.47 \mathrm{E}+03$ & $2.55 E+03$ & $2.56 \mathrm{E}+03$ & $2.53 \mathrm{E}+03$ & $2.0 \%$ \\
\hline B (IE) & $<3.8 \mathrm{E}-01$ & $<3.8 \mathrm{E}-01$ & $<3.8 \mathrm{E}-01$ & - & - \\
\hline Ba (IE) & 3.74E-01 & 3.13E-01 & 3.17E-01 & 3.35E-01 & $10 \%$ \\
\hline Ca (IE) & $3.02 \mathrm{E}+00$ & $2.98 \mathrm{E}+00$ & $2.99 \mathrm{E}+00$ & $3.00 \mathrm{E}+00$ & $0.7 \%$ \\
\hline Cd (IE) & $<7.7 \mathrm{E}-02$ & $<7.7 \mathrm{E}-02$ & $<7.7 \mathrm{E}-02$ & - & - \\
\hline Ce (IE) & $7.76 \mathrm{E}+00$ & $6.23 \mathrm{E}+00$ & $6.40 \mathrm{E}+00$ & $6.80 \mathrm{E}+00$ & $12 \%$ \\
\hline $\mathrm{Cr}$ (IE) & $9.96 \mathrm{E}-01$ & $1.07 \mathrm{E}+00$ & 9.74E-01 & $1.01 \mathrm{E}+00$ & $5.0 \%$ \\
\hline $\mathrm{Cu}$ (IE) & $<2.7 \mathrm{E}-02$ & $<2.7 \mathrm{E}-02$ & $<2.7 \mathrm{E}-02$ & - & - \\
\hline Fe (IE) & $<5.8 \mathrm{E}-02$ & $<5.8 \mathrm{E}-02$ & $<5.8 \mathrm{E}-02$ & - & - \\
\hline Gd (IE) & $<2.8 \mathrm{E}-01$ & $<2.2 \mathrm{E}-01$ & $<2.2 \mathrm{E}-01$ & - & - \\
\hline K (IE) & $6.45 \mathrm{E}+02$ & $6.47 \mathrm{E}+02$ & $6.42 \mathrm{E}+02$ & $6.45 \mathrm{E}+02$ & $0.4 \%$ \\
\hline La (IE) & $1.72 \mathrm{E}+00$ & $1.41 \mathrm{E}+00$ & $1.47 \mathrm{E}+00$ & $1.53 E+00$ & $11 \%$ \\
\hline $\mathrm{Li}$ (IE) & $9.10 \mathrm{E}-01$ & 8.03E-01 & 8.21E-01 & 8.45E-01 & $6.8 \%$ \\
\hline Mg (IE) & $<1.3 \mathrm{E}-01$ & $<1.3 \mathrm{E}-01$ & $<1.3 \mathrm{E}-01$ & - & - \\
\hline Mn (IE) & $<1.7 \mathrm{E}-02$ & $<1.7 \mathrm{E}-02$ & $<1.7 \mathrm{E}-02$ & - & - \\
\hline Mo (IE) & $1.44 \mathrm{E}+01$ & $1.45 \mathrm{E}+01$ & $1.46 \mathrm{E}+01$ & $1.45 \mathrm{E}+01$ & $0.7 \%$ \\
\hline $\mathrm{Na}$ (IE) & $3.54 \mathrm{E}+04$ & $3.48 \mathrm{E}+04$ & $3.46 \mathrm{E}+04$ & $3.49 \mathrm{E}+04$ & $1.2 \%$ \\
\hline $\mathrm{Ni}$ (IE) & $<5.7 \mathrm{E}-01$ & $<5.7 \mathrm{E}-01$ & $<5.7 \mathrm{E}-01$ & - & - \\
\hline$P$ (IE) & $1.68 \mathrm{E}+02$ & $1.66 \mathrm{E}+02$ & $1.68 \mathrm{E}+02$ & $1.67 \mathrm{E}+02$ & $0.7 \%$ \\
\hline $\mathrm{Pb}$ (IE) & $<4.9 \mathrm{E}+00$ & $<4.9 \mathrm{E}+00$ & $<4.9 \mathrm{E}+00$ & - & - \\
\hline$S$ (IE) & $2.37 \mathrm{E}+03$ & $2.34 \mathrm{E}+03$ & $2.31 \mathrm{E}+03$ & $2.34 \mathrm{E}+03$ & $1.3 \%$ \\
\hline Sb (IE) & $8.68 \mathrm{E}+00$ & $8.96 \mathrm{E}+00$ & $9.11 \mathrm{E}+00$ & $8.92 \mathrm{E}+00$ & $2.4 \%$ \\
\hline Si (IE) & $1.01 \mathrm{E}+01$ & $9.74 \mathrm{E}+00$ & $9.78 \mathrm{E}+00$ & $9.87 E+00$ & $2.0 \%$ \\
\hline Sn (IE) & $1.55 \mathrm{E}+01$ & $1.19 \mathrm{E}+01$ & $1.39 \mathrm{E}+01$ & $1.38 \mathrm{E}+01$ & $13 \%$ \\
\hline $\mathrm{Sr}$ (IE) & $1.67 \mathrm{E}+00$ & $1.42 \mathrm{E}+00$ & $1.47 E+00$ & $1.52 E+00$ & $8.7 \%$ \\
\hline
\end{tabular}


WSRC-STI-2007-00192, REV. 1

Table 3-12. Composition of the Filtrate from the $50{ }^{\circ} \mathrm{C}$ Neutralization Test (continued)

\begin{tabular}{|l|c|c|c|c|c|}
\hline Analyte & $\begin{array}{c}\text { 1st } \\
\text { Replicate } \\
\text { (mg/L) }\end{array}$ & $\begin{array}{c}\text { 2nd } \\
\text { Replicate } \\
\text { (mg/L) }\end{array}$ & $\begin{array}{c}\text { 3rd } \\
\text { Replicate } \\
\text { (mg/L) }\end{array}$ & $\begin{array}{c}\text { Average } \\
\text { (mg/L) }\end{array}$ & \%RSD \\
\hline Ti (IE) & $<3.8 \mathrm{E}-02$ & $<3.8 \mathrm{E}-02$ & $<3.8 \mathrm{E}-02$ & - & - \\
\hline U (IE) & $1.20 \mathrm{E}+01$ & $1.27 \mathrm{E}+01$ & $1.19 \mathrm{E}+01$ & $1.22 \mathrm{E}+01$ & $3.6 \%$ \\
\hline $\mathrm{V}$ (IE) & $7.78 \mathrm{E}-01$ & $7.29 \mathrm{E}-01$ & $7.02 \mathrm{E}-01$ & $7.36 \mathrm{E}-01$ & $5.2 \%$ \\
\hline $\mathrm{Zn} \mathrm{(IE)}$ & $4.35 \mathrm{E}-01$ & $3.55 \mathrm{E}-01$ & $3.56 \mathrm{E}-01$ & $3.82 \mathrm{E}-01$ & $12 \%$ \\
\hline $\mathrm{Zr} \mathrm{(IE)}$ & $<7.9 \mathrm{E}-02$ & $<7.9 \mathrm{E}-02$ & $<7.9 \mathrm{E}-02$ & - & - \\
\hline
\end{tabular}


Table 3-13. Composition of the Filtrate from the $75{ }^{\circ} \mathrm{C}$ Neutralization Test

\begin{tabular}{|c|c|c|c|c|c|}
\hline Analyte & $\begin{array}{c}\text { 1st } \\
\text { Replicate } \\
\text { (mg/L) }\end{array}$ & $\begin{array}{c}\text { 2nd } \\
\text { Replicate } \\
\text { (mg/L) }\end{array}$ & $\begin{array}{c}\text { 3rd } \\
\text { Replicate } \\
\text { (mg/L) }\end{array}$ & $\begin{array}{c}\text { Average } \\
\text { (mg/L) }\end{array}$ & \%RSD \\
\hline Ag (IE) & $<1.7 \mathrm{E}-01$ & $<1.7 \mathrm{E}-01$ & $<1.7 \mathrm{E}-01$ & - & - \\
\hline Al (IE) & $3.35 E+03$ & $3.22 \mathrm{E}+03$ & $3.31 E+03$ & $3.29 \mathrm{E}+03$ & $2.0 \%$ \\
\hline B (IE) & $<3.8 \mathrm{E}-01$ & $<3.8 \mathrm{E}-01$ & $<3.8 \mathrm{E}-01$ & - & - \\
\hline Ba (IE) & 3.32E-01 & 3.23E-01 & 3.37E-01 & 3.31E-01 & $2.1 \%$ \\
\hline $\mathrm{Ca}$ (IE) & $3.04 \mathrm{E}+00$ & $3.11 \mathrm{E}+00$ & $3.07 E+00$ & $3.07 \mathrm{E}+00$ & $1.1 \%$ \\
\hline Cd (IE) & $<7.7 \mathrm{E}-02$ & $<7.7 \mathrm{E}-02$ & $<7.7 \mathrm{E}-02$ & - & - \\
\hline Ce (IE) & $6.56 \mathrm{E}+00$ & $6.87 \mathrm{E}+00$ & $6.35 \mathrm{E}+00$ & $6.59 \mathrm{E}+00$ & $4.0 \%$ \\
\hline $\mathrm{Cr}$ (IE) & $<3.9 \mathrm{E}-01$ & 4.09E-01 & $<3.9 \mathrm{E}-01$ & - & - \\
\hline $\mathrm{Cu}$ (IE) & $<2.7 \mathrm{E}-02$ & $<2.7 \mathrm{E}-02$ & $<2.7 \mathrm{E}-02$ & - & - \\
\hline Fe (IE) & $<5.8 \mathrm{E}-02$ & $<5.8 \mathrm{E}-02$ & $<5.8 \mathrm{E}-02$ & - & - \\
\hline Gd (IE) & $<2.2 \mathrm{E}-01$ & $<2.2 \mathrm{E}-01$ & $<2.2 \mathrm{E}-01$ & - & - \\
\hline $\mathrm{K}$ (IE) & $6.69 \mathrm{E}+02$ & $6.89 E+02$ & $6.81 \mathrm{E}+02$ & $6.80 \mathrm{E}+02$ & $1.5 \%$ \\
\hline La (IE) & $1.55 \mathrm{E}+00$ & $1.64 \mathrm{E}+00$ & $1.51 \mathrm{E}+00$ & $1.57 \mathrm{E}+00$ & $4.2 \%$ \\
\hline Li (IE) & $1.21 \mathrm{E}+00$ & $1.20 \mathrm{E}+00$ & $1.20 \mathrm{E}+00$ & $1.20 \mathrm{E}+00$ & $0.5 \%$ \\
\hline $\mathrm{Mg}$ (IE) & $<1.3 \mathrm{E}-01$ & $<1.3 \mathrm{E}-01$ & $<1.3 \mathrm{E}-01$ & - & - \\
\hline $\mathrm{Mn}$ (IE) & $<1.7 \mathrm{E}-02$ & $<1.7 \mathrm{E}-02$ & $<1.7 \mathrm{E}-02$ & - & - \\
\hline Mo (IE) & $1.60 \mathrm{E}+01$ & $1.64 \mathrm{E}+01$ & $1.70 \mathrm{E}+01$ & $1.65 \mathrm{E}+01$ & $3.1 \%$ \\
\hline $\mathrm{Na}$ (IE) & $3.74 \mathrm{E}+04$ & $3.66 \mathrm{E}+04$ & $3.72 E+04$ & $3.71 \mathrm{E}+04$ & $1.1 \%$ \\
\hline $\mathrm{Ni}$ (IE) & $<5.7 \mathrm{E}-01$ & $<5.7 \mathrm{E}-01$ & $<5.7 \mathrm{E}-01$ & - & - \\
\hline$P$ (IE) & $1.62 \mathrm{E}+02$ & $1.61 \mathrm{E}+02$ & $1.64 \mathrm{E}+02$ & $1.62 \mathrm{E}+02$ & $0.9 \%$ \\
\hline $\mathrm{Pb}$ (IE) & $<4.9 \mathrm{E}+00$ & $<4.9 \mathrm{E}+00$ & $<4.9 \mathrm{E}+00$ & - & - \\
\hline$S$ (IE) & $2.29 E+03$ & $2.42 \mathrm{E}+03$ & $2.32 E+03$ & $2.34 \mathrm{E}+03$ & $2.9 \%$ \\
\hline Sb (IE) & $1.20 \mathrm{E}+01$ & $1.16 \mathrm{E}+01$ & $1.20 \mathrm{E}+01$ & $1.19 \mathrm{E}+01$ & $1.9 \%$ \\
\hline Si (IE) & $1.22 \mathrm{E}+01$ & $1.21 \mathrm{E}+01$ & $1.23 \mathrm{E}+01$ & $1.22 \mathrm{E}+01$ & $0.8 \%$ \\
\hline Sn (IE) & $1.74 \mathrm{E}+01$ & $1.74 \mathrm{E}+01$ & $1.58 \mathrm{E}+01$ & $1.69 \mathrm{E}+01$ & $5.5 \%$ \\
\hline Sr (IE) & $1.52 \mathrm{E}+00$ & $1.62 E+00$ & $1.49 \mathrm{E}+00$ & $1.54 \mathrm{E}+00$ & $4.4 \%$ \\
\hline
\end{tabular}


WSRC-STI-2007-00192, REV. 1

Table 3-13. Composition of the Filtrate from the $75^{\circ} \mathrm{C}$ Neutralization Test (continued)

\begin{tabular}{|l|c|c|c|c|c|}
\hline Analyte & $\begin{array}{c}\text { 1st } \\
\text { Replicate } \\
\text { (mg/L) }\end{array}$ & $\begin{array}{c}\text { 2nd } \\
\text { Replicate } \\
\text { (mg/L) }\end{array}$ & $\begin{array}{c}\text { 3rd } \\
\text { Replicate } \\
\text { (mg/L) }\end{array}$ & $\begin{array}{c}\text { Average } \\
\text { (mg/L) }\end{array}$ & \%RSD \\
\hline Ti (IE) & $<3.8 \mathrm{E}-02$ & $<3.8 \mathrm{E}-02$ & $<3.8 \mathrm{E}-02$ & - & - \\
\hline U (IE) & $3.89 \mathrm{E}+01$ & $3.91 \mathrm{E}+01$ & $3.78 \mathrm{E}+01$ & $3.86 \mathrm{E}+01$ & $1.8 \%$ \\
\hline $\mathrm{V}$ (IE) & $1.04 \mathrm{E}+00$ & $1.05 \mathrm{E}+00$ & $1.09 \mathrm{E}+00$ & $1.06 \mathrm{E}+00$ & $2.5 \%$ \\
\hline $\mathrm{Zn} \mathrm{(IE)}$ & $3.97 \mathrm{E}-01$ & $4.13 \mathrm{E}-01$ & $3.79 \mathrm{E}-01$ & $3.96 \mathrm{E}-01$ & $4.3 \%$ \\
\hline $\mathrm{Zr} \mathrm{(IE)}$ & $<7.9 \mathrm{E}-02$ & $<7.9 \mathrm{E}-02$ & $<7.9 \mathrm{E}-02$ & - & - \\
\hline
\end{tabular}




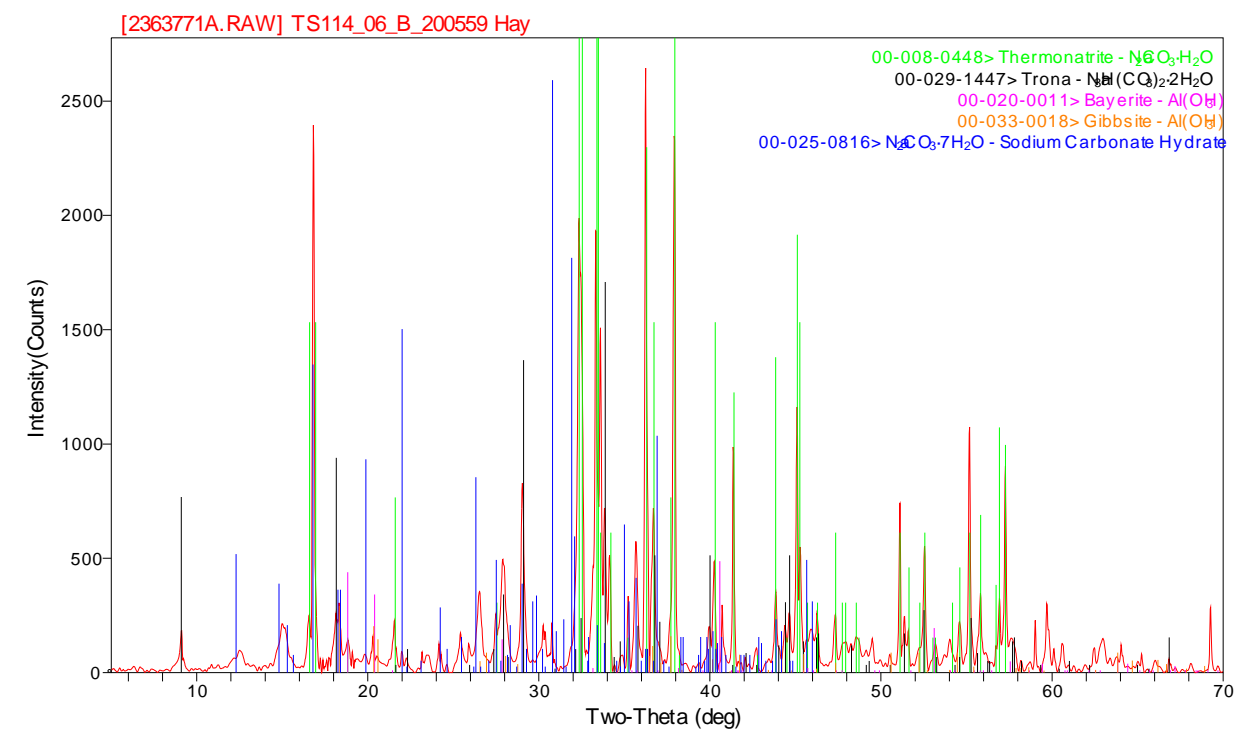

Figure 3.1 X-Ray Diffraction for White Solids from Tank 5F Sample FTF-05-07-1, Replicate 1

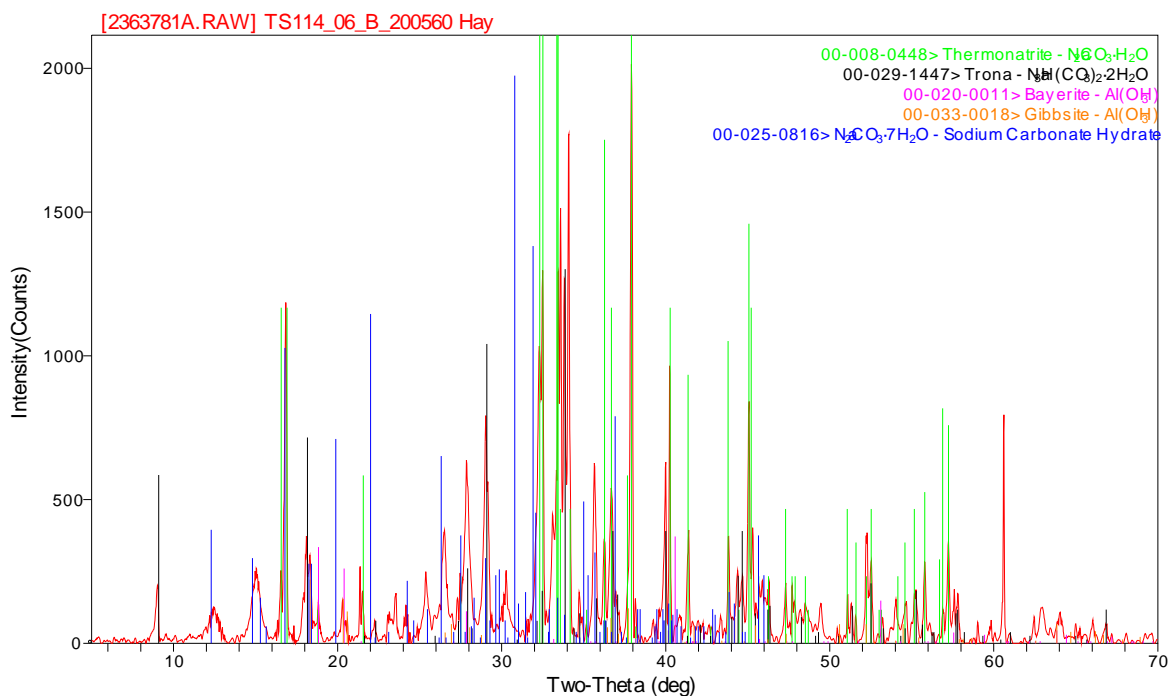

Figure 3.2 X-Ray Diffraction for White Solids from Tank 5F Sample FTF-05-07-1, Replicate 2 
WSRC-STI-2007-00192, REV. 1

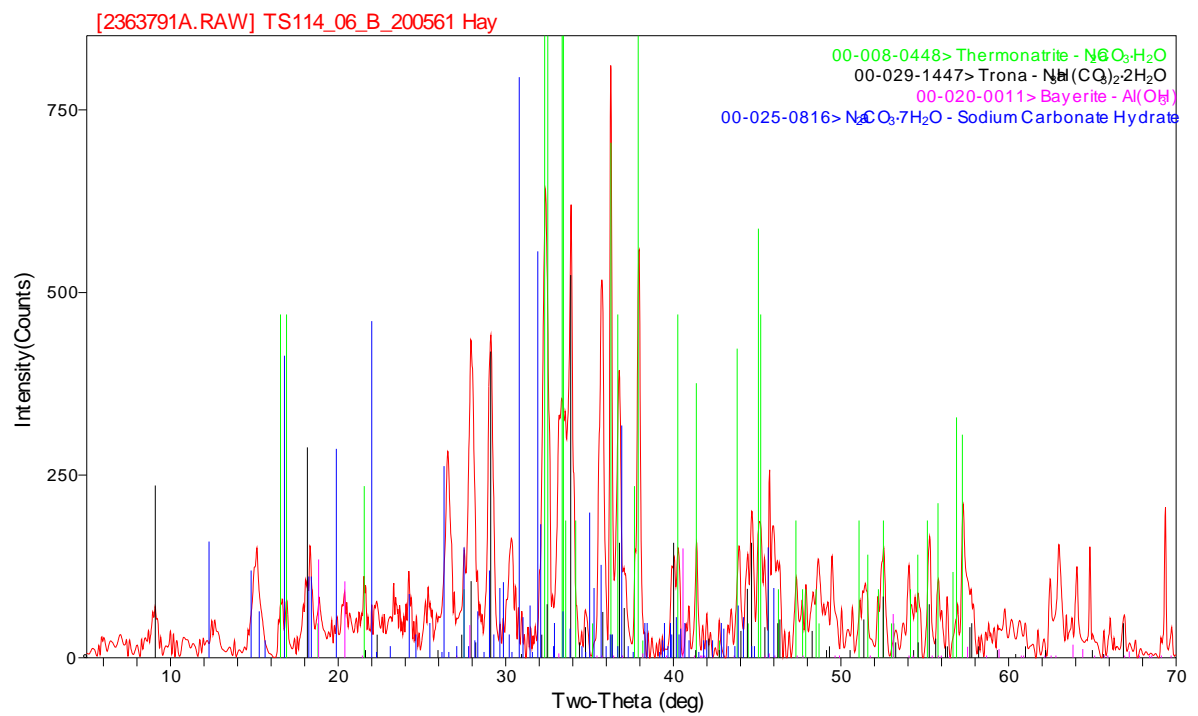

Figure 3.3 X-Ray Diffraction for White Solids from Tank 5F Sample FTF-05-07-1, Replicate 3 




Figure 3.4 SEM Micrograph of Solids from Tank 5F Sludge Sample (18X Magnification)

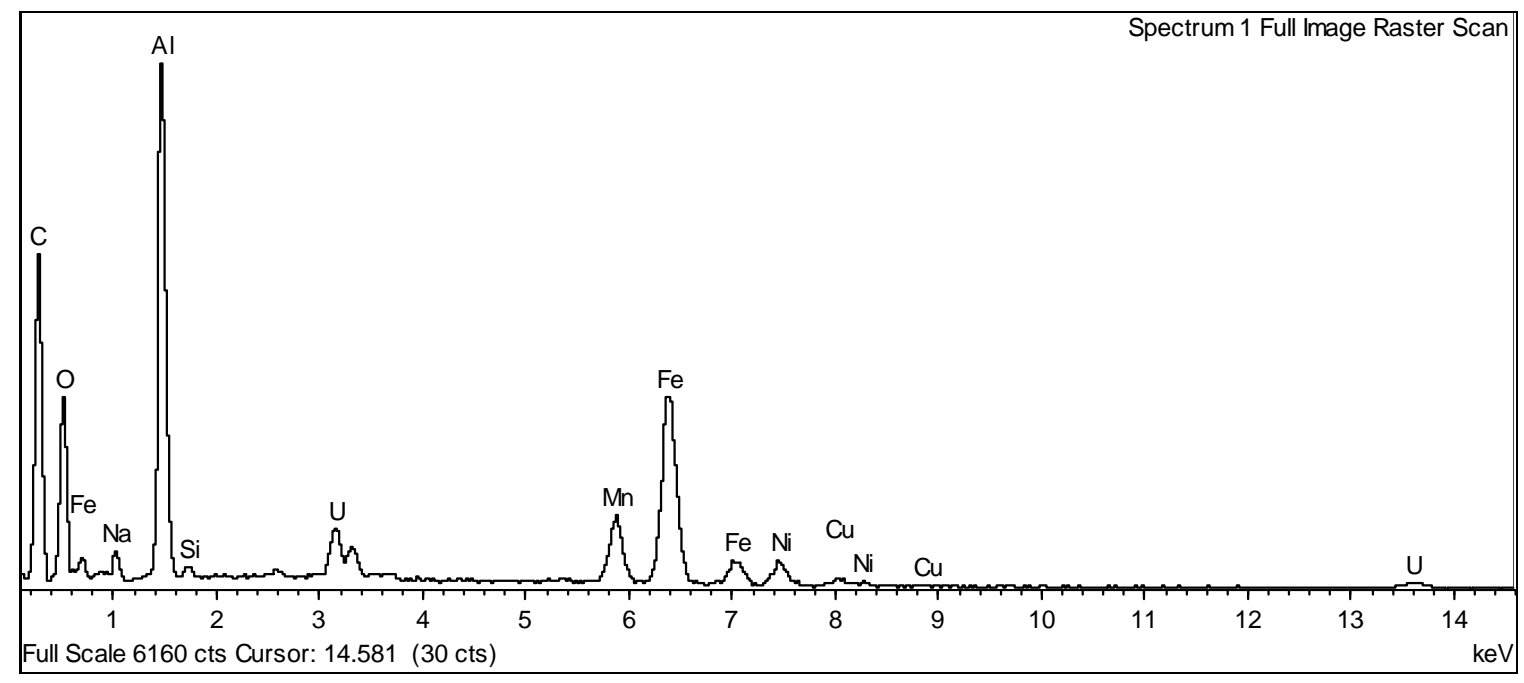

Figure 3.5 Spectrum of Spot 1 from Figure 3.4 
WSRC-STI-2007-00192, REV. 1

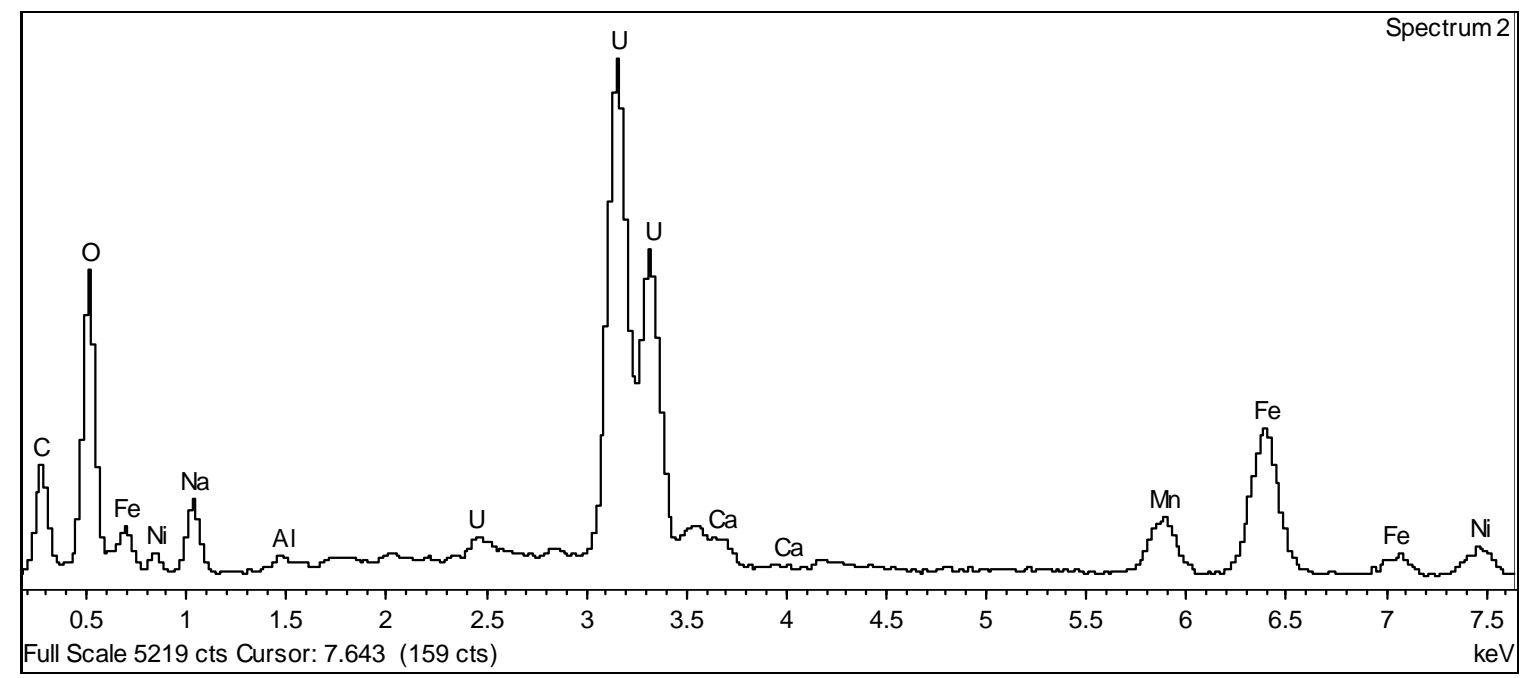

Figure 3.6 Spectrum of Spot 2 from Figure 3.4

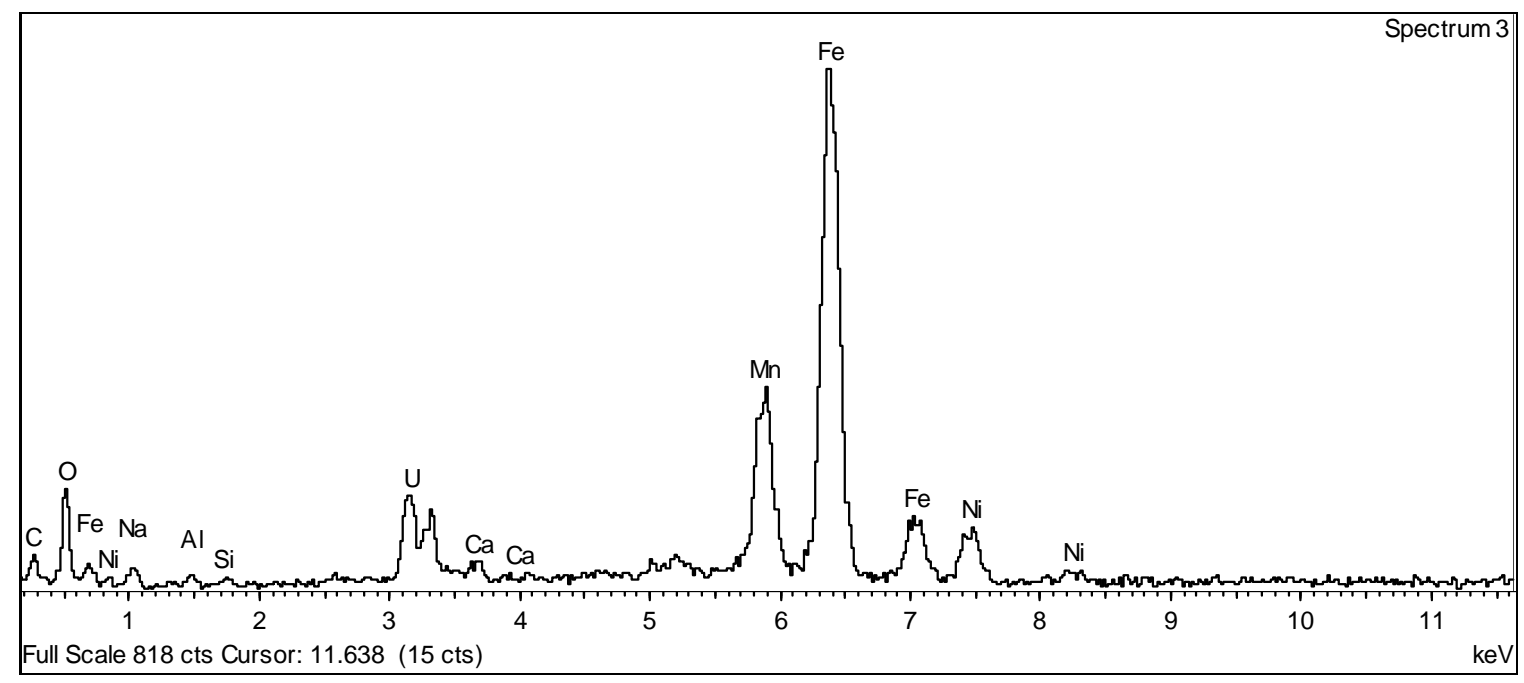

Figure 3.7 Spectrum of Spot 3 from Figure 3.4 
WSRC-STI-2007-00192, REV. 1

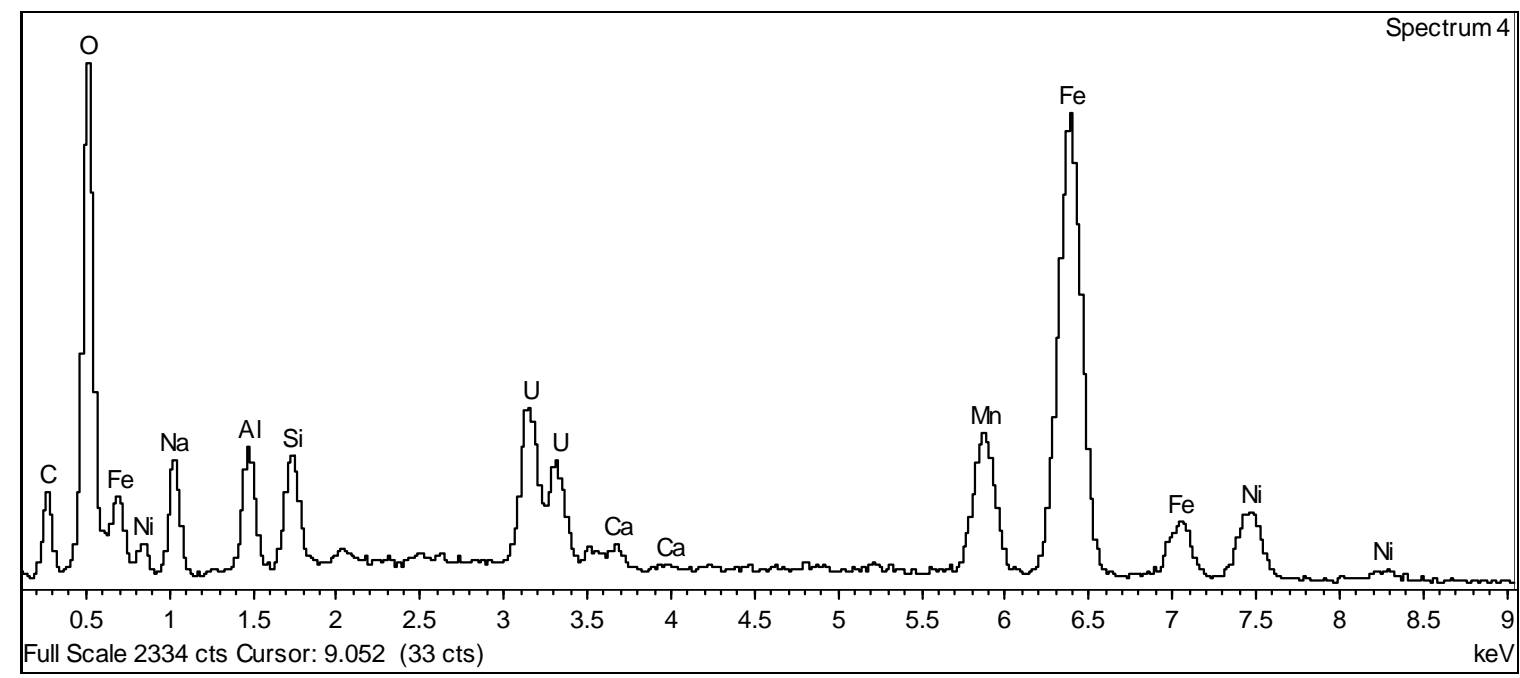

Figure 3.8 Spectrum of Spot 4 from Figure 3.4

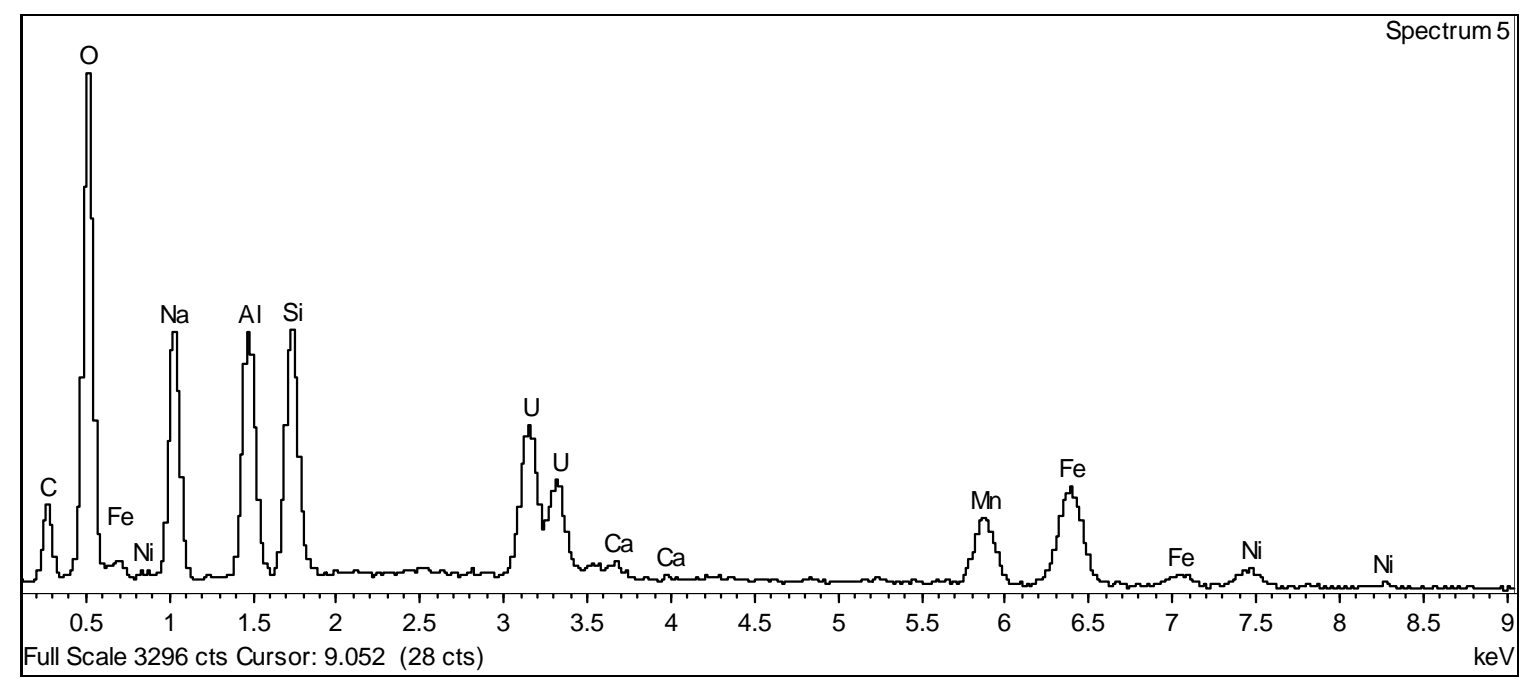

Figure 3.9 Spectrum of Spot 5 from Figure 3.4 


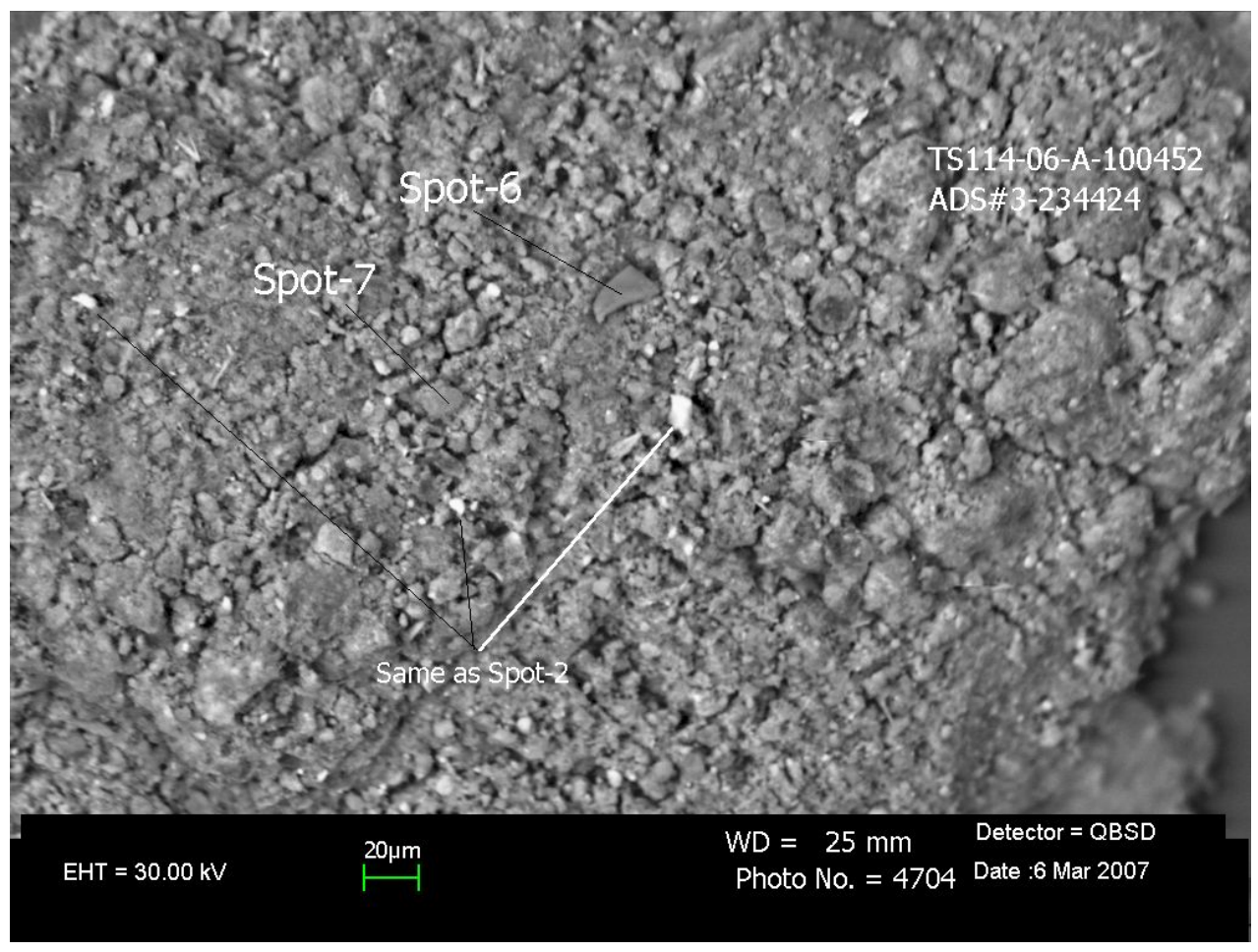

Figure 3.10 SEM Micrograph of Solids from Tank 5F Sludge Sample (250X Magnification)

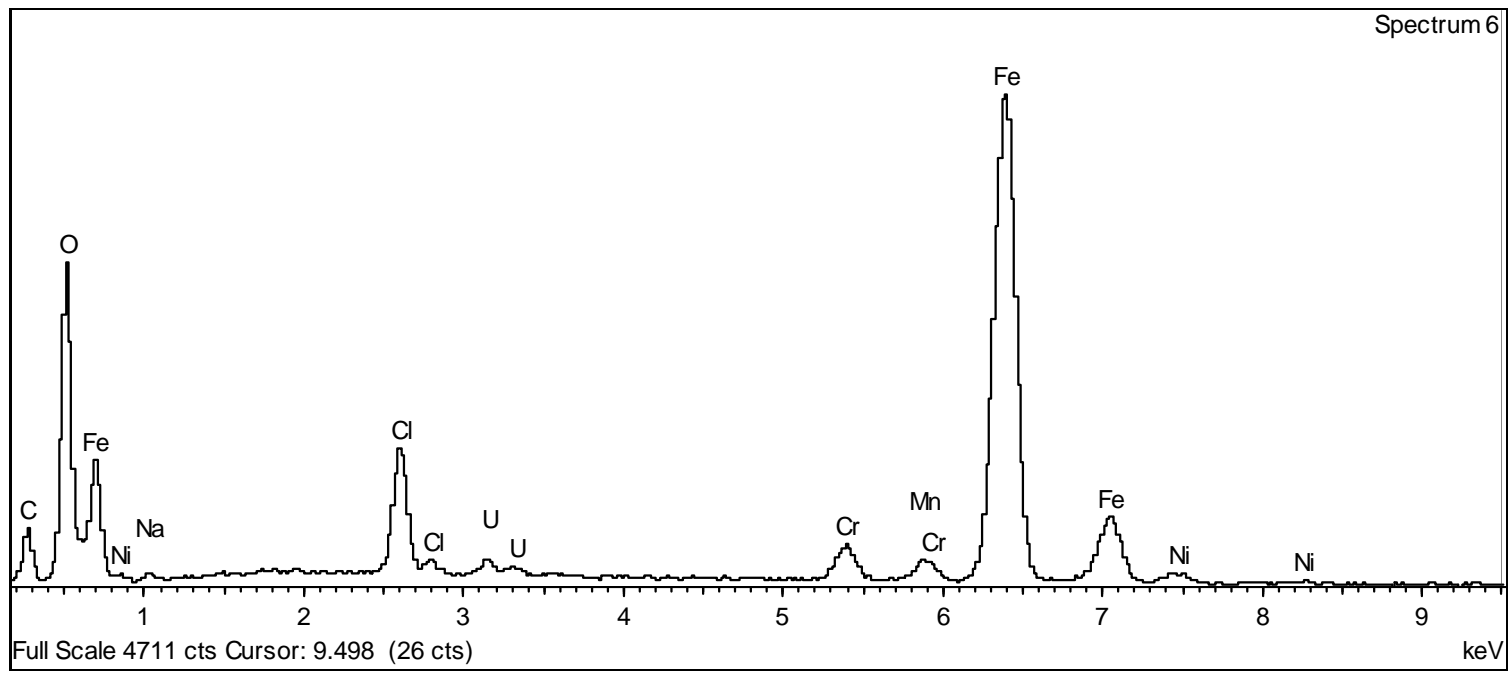

Figure 3.11 Spectrum of Spot 6 from Figure 3.10 


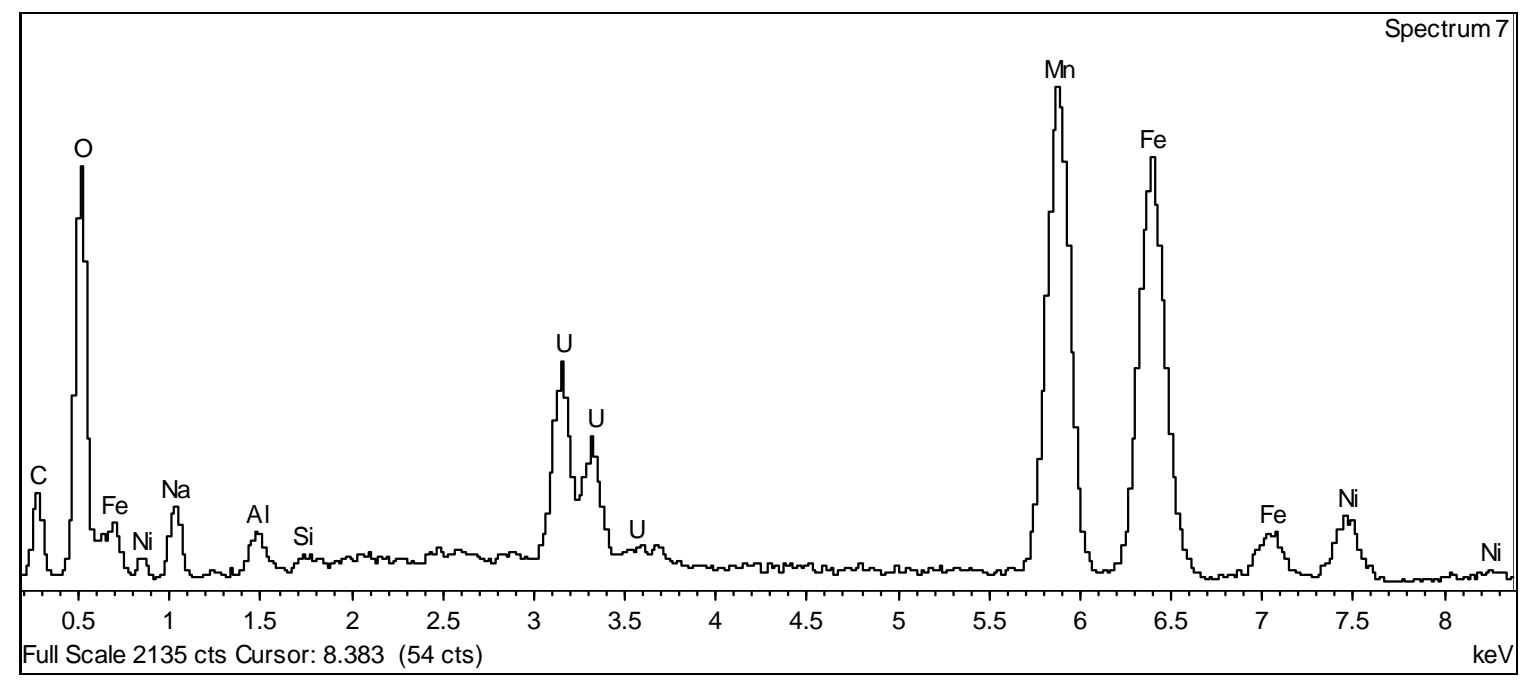

Figure 3.12 Spectrum of Spot 7 from Figure 3.10

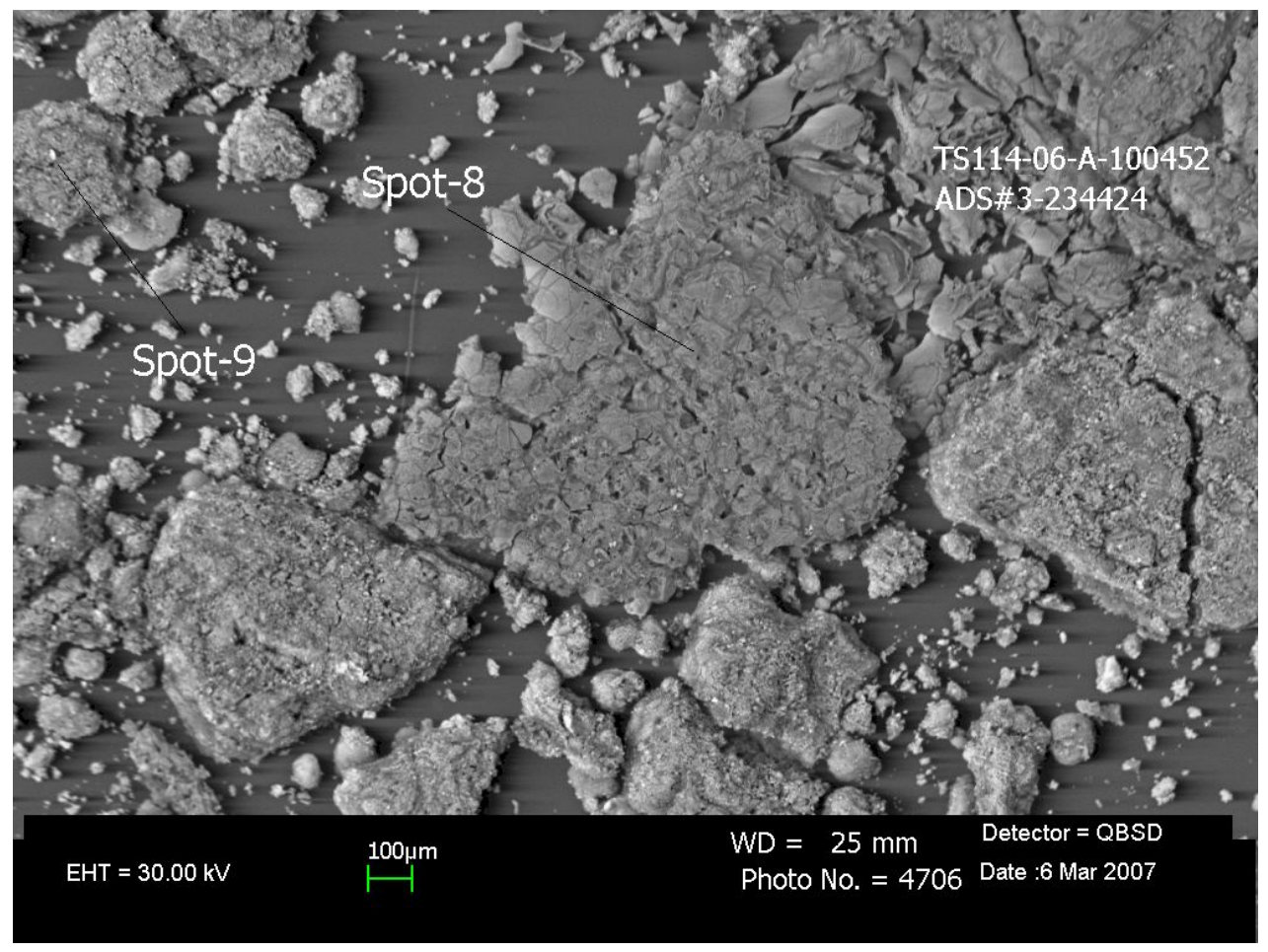

Figure 3.13 SEM Micrograph of Solids from Tank 5F Sludge Sample (40X Magnification) 
WSRC-STI-2007-00192, REV. 1

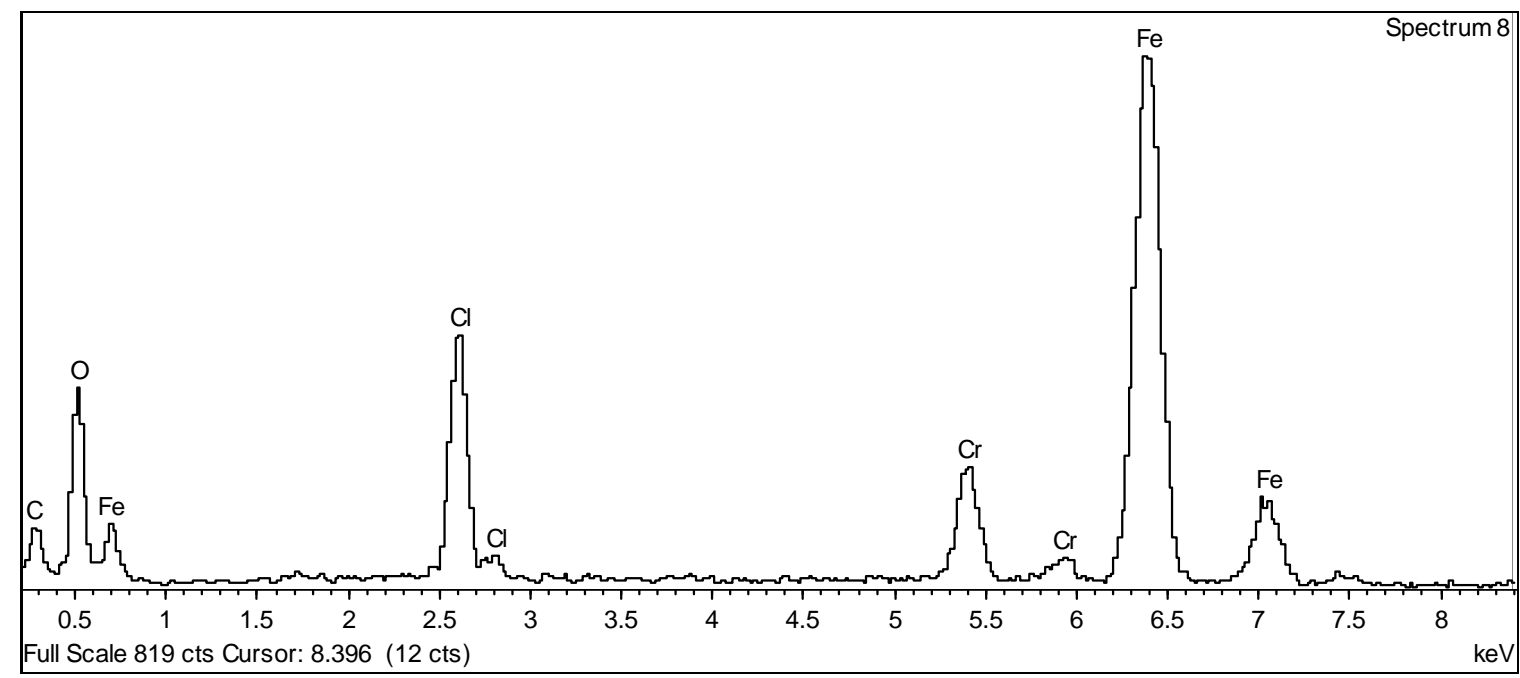

Figure 3.14 Spectrum of Spot 8 from Figure 3.13

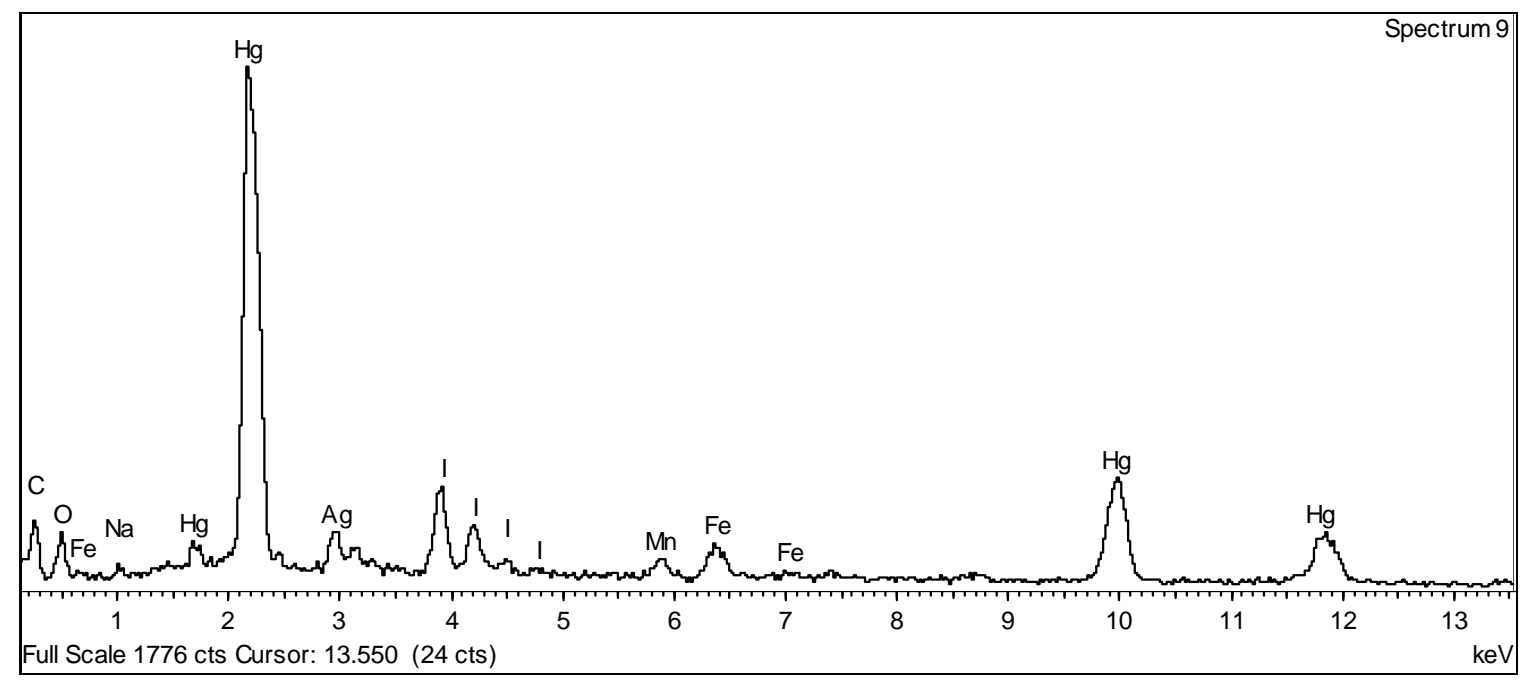

Figure 3.15 Spectrum of Spot 9 from Figure 3.13 


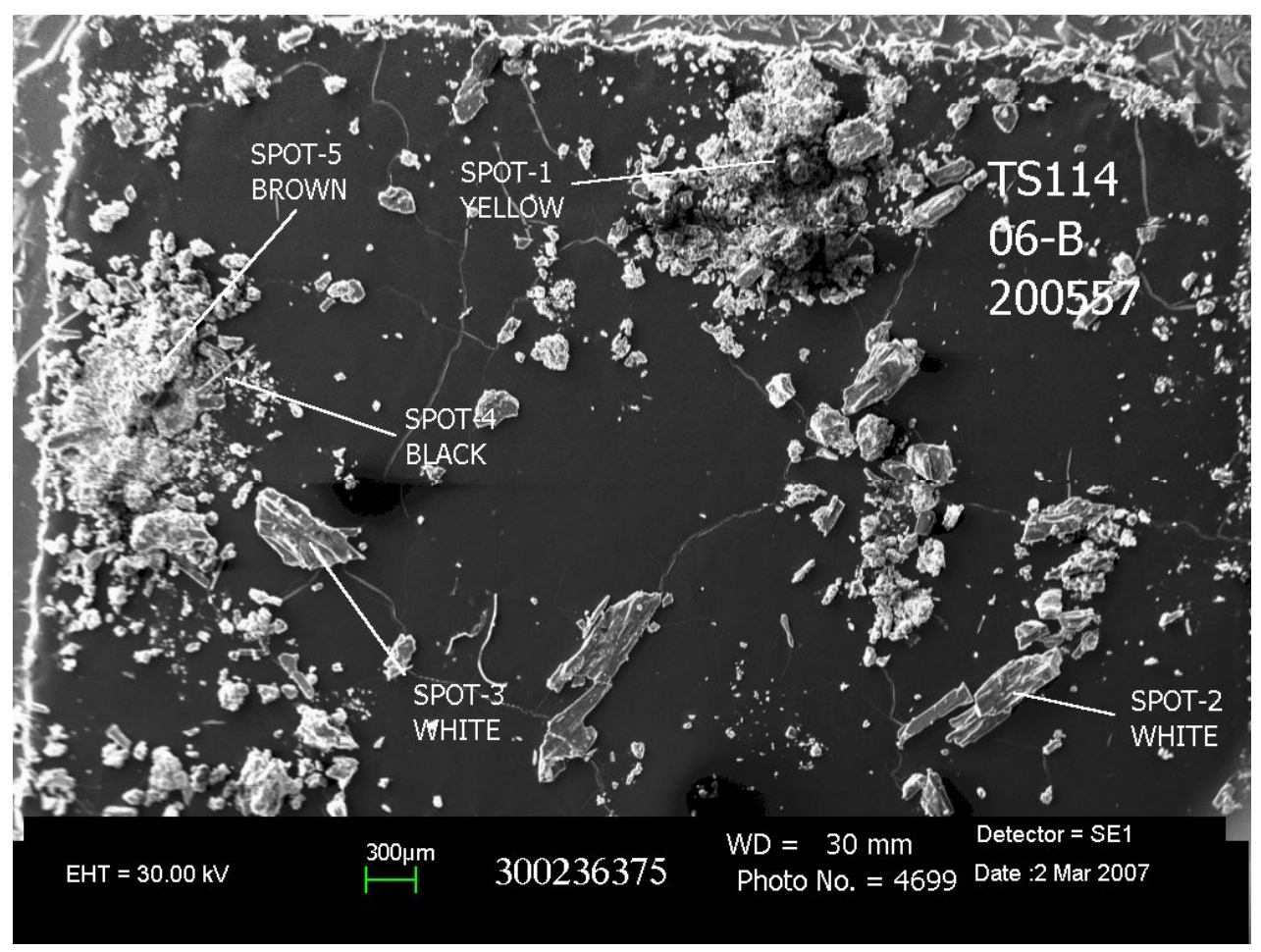

Figure 3.16 SEM Micrograph of Solids from Tank 5F Salt Sample (15X Magnification)

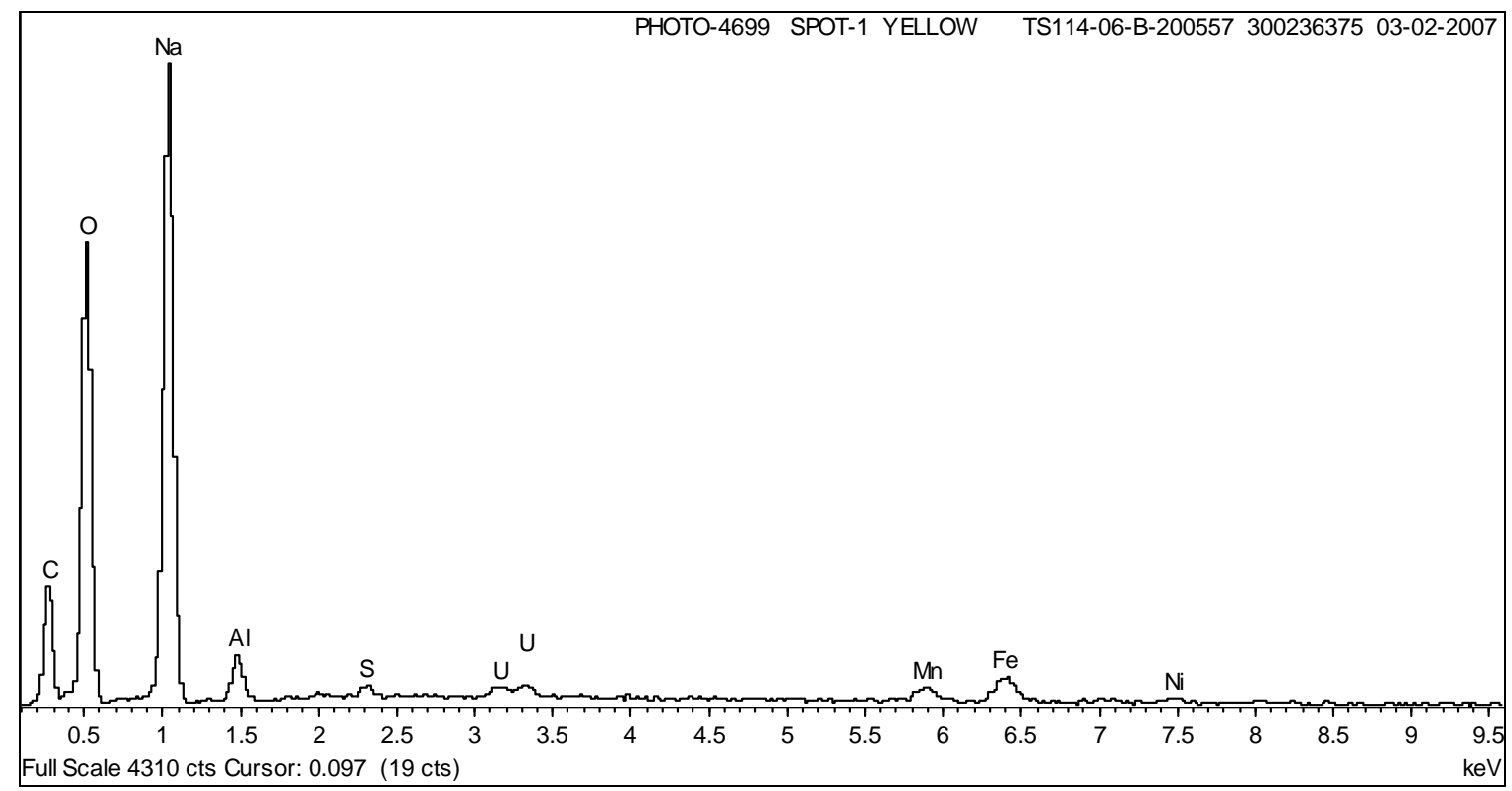

Figure 3.17 Spectrum of Spot 1 from Figure 3.16 
WSRC-STI-2007-00192, REV. 1

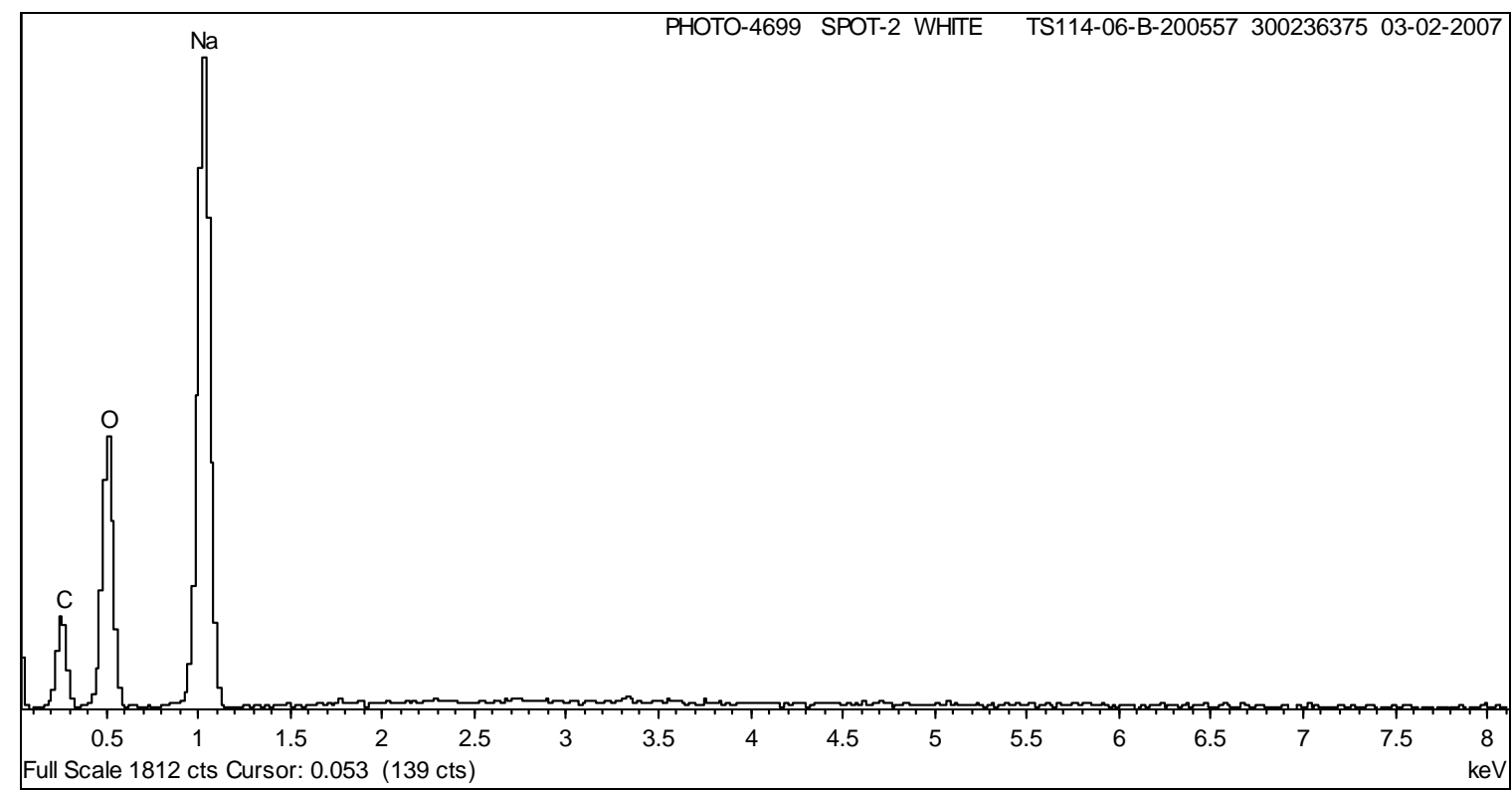

Figure 3.18 Spectrum of Spot 2 from Figure 3.16

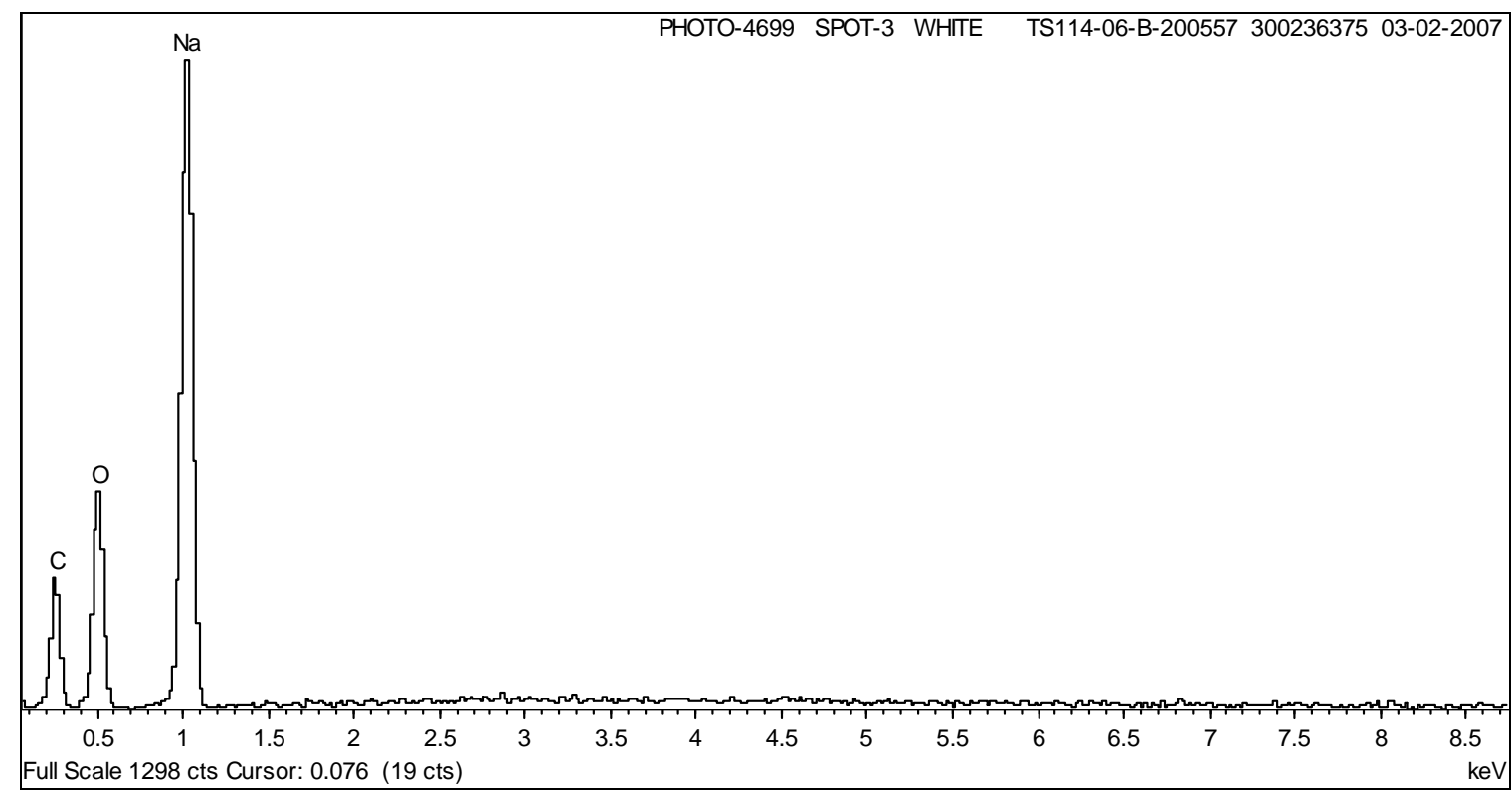

Figure 3.19 Spectrum of Spot 3 from Figure 3.16 


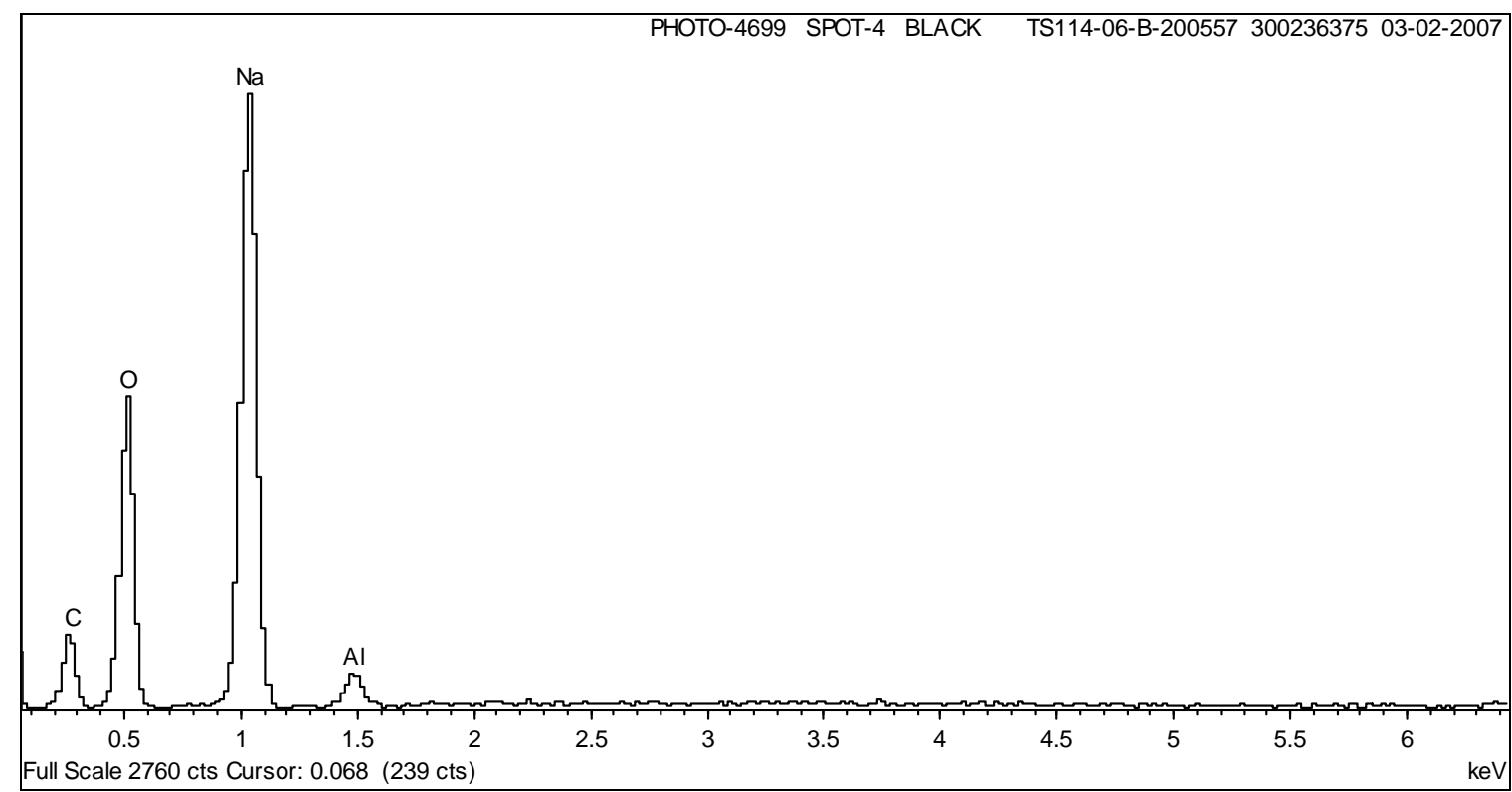

Figure 3.20 Spectrum of Spot 4 from Figure 3.16

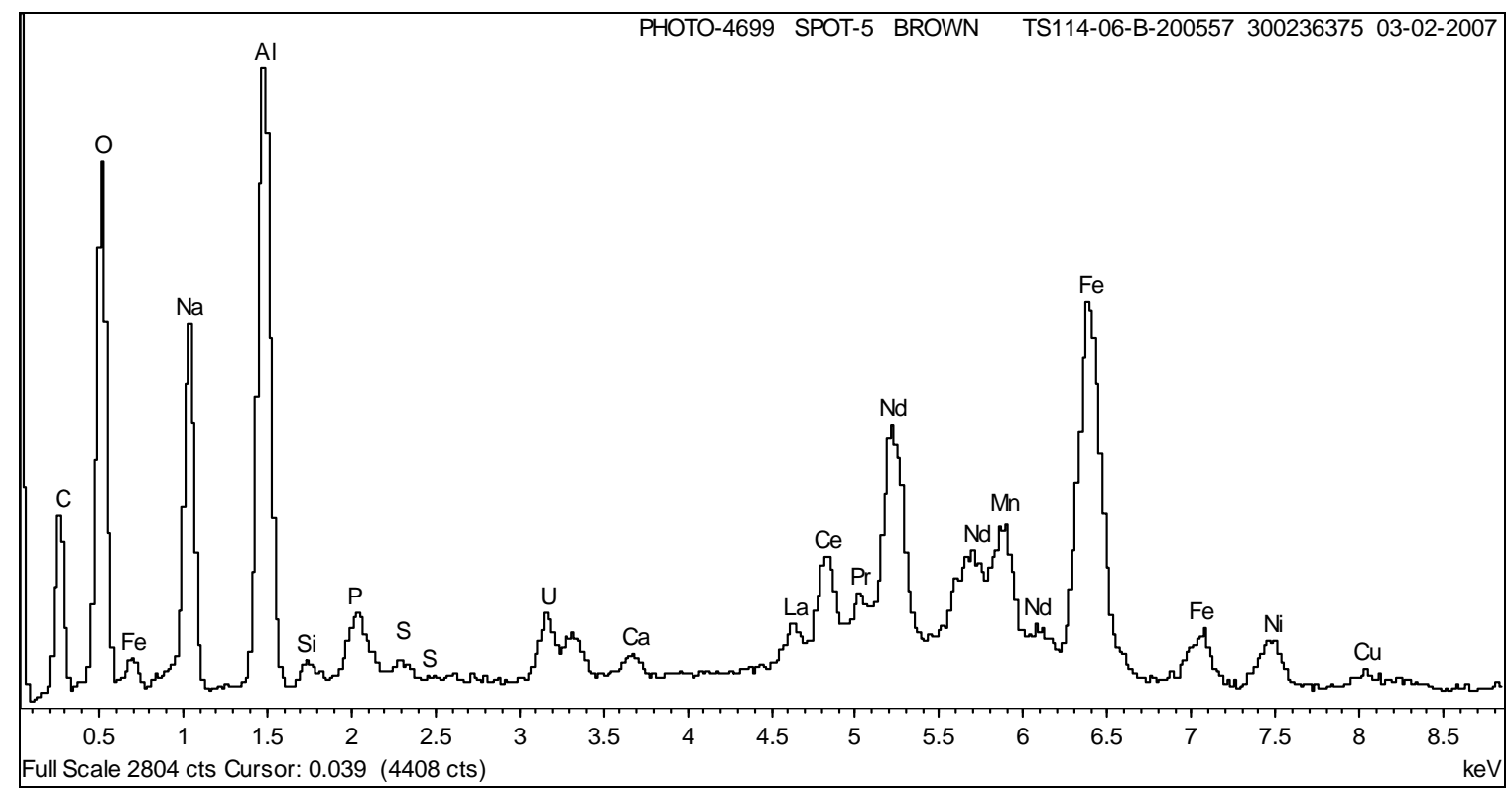

Figure 3.21 Spectrum of Spot 5 from Figure 3.16 


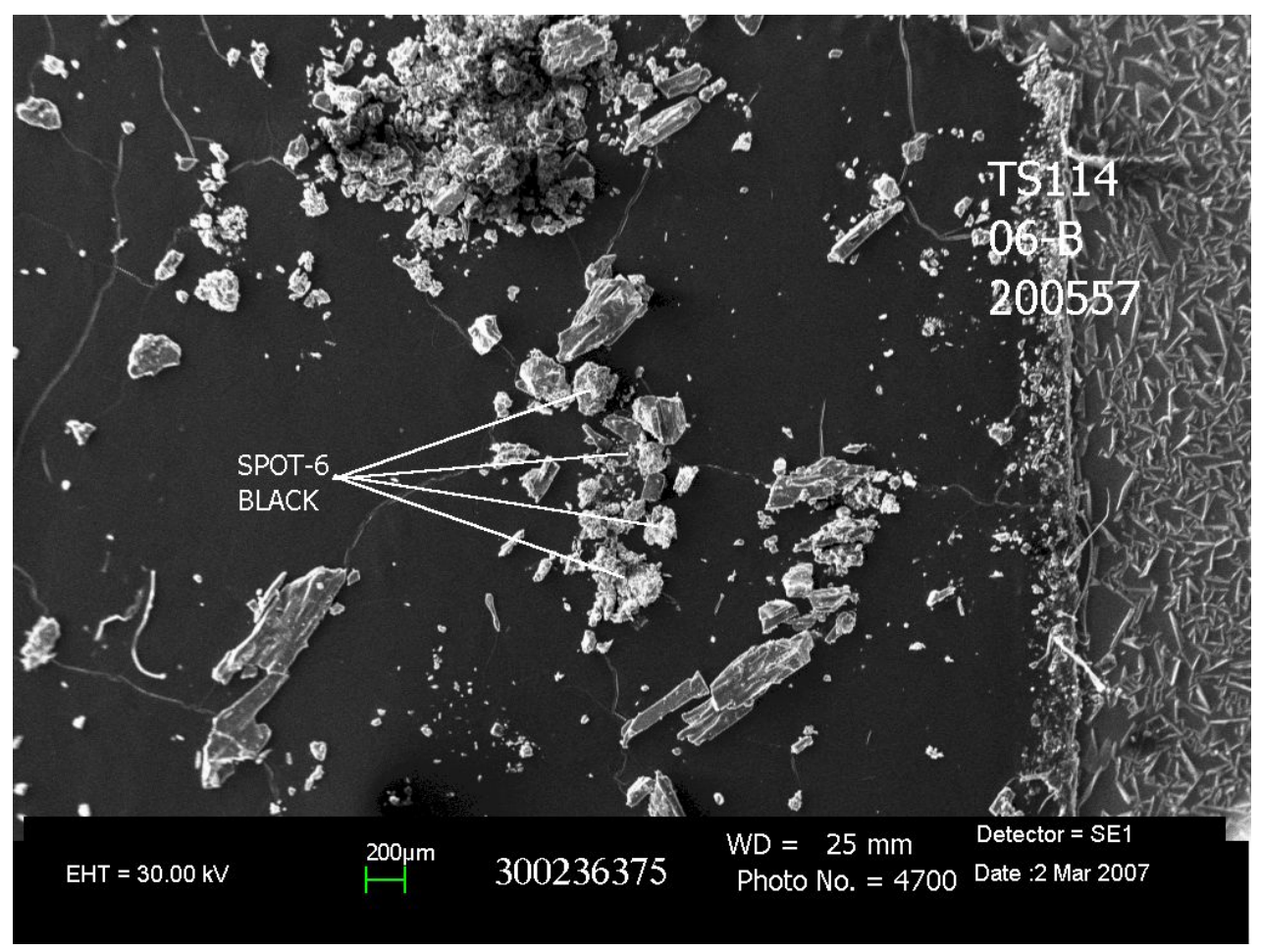

Figure 3.22 SEM Micrograph of Solids from Tank 5F Salt Sample (18X Magnification)

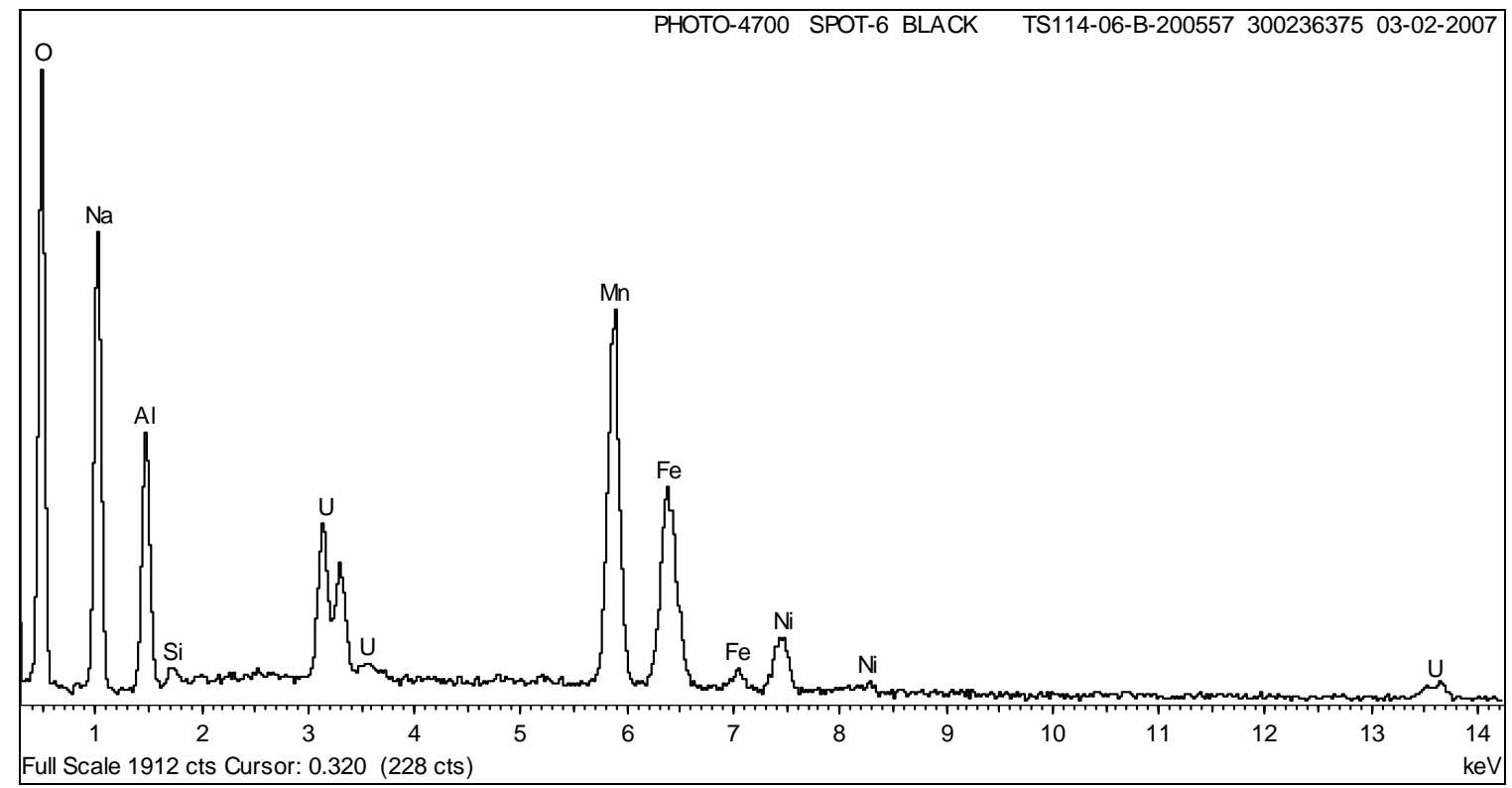

Figure 3.23 Spectrum of Spot 6 from Figure 3.22 




Figure 3.24 SEM Micrograph of Solids from $50^{\circ} \mathrm{C}$ Oxalic Acid Test (18X Magnification)

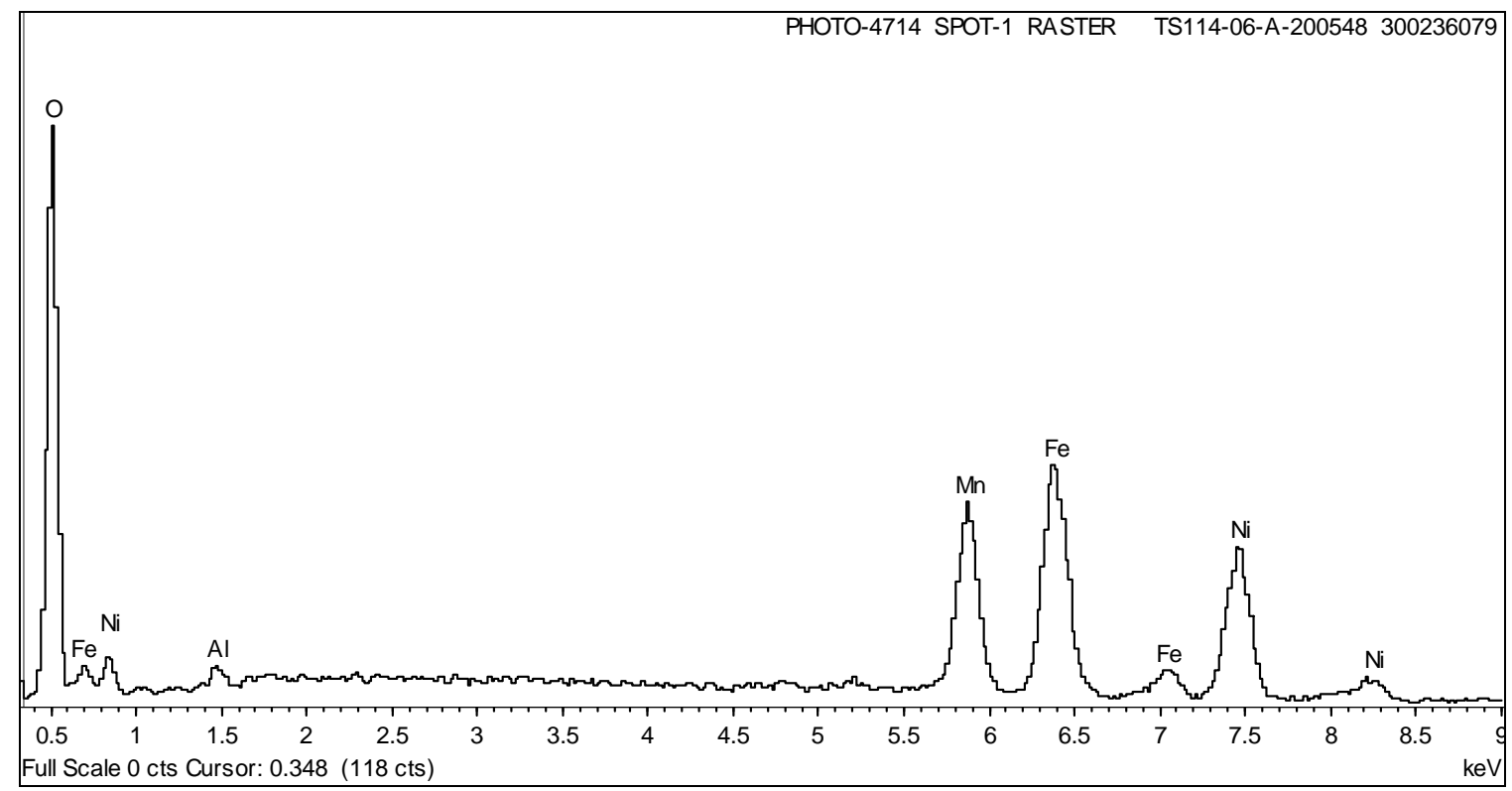

Figure 3.25 Spectrum of Spot 1 from Figure 3.24 


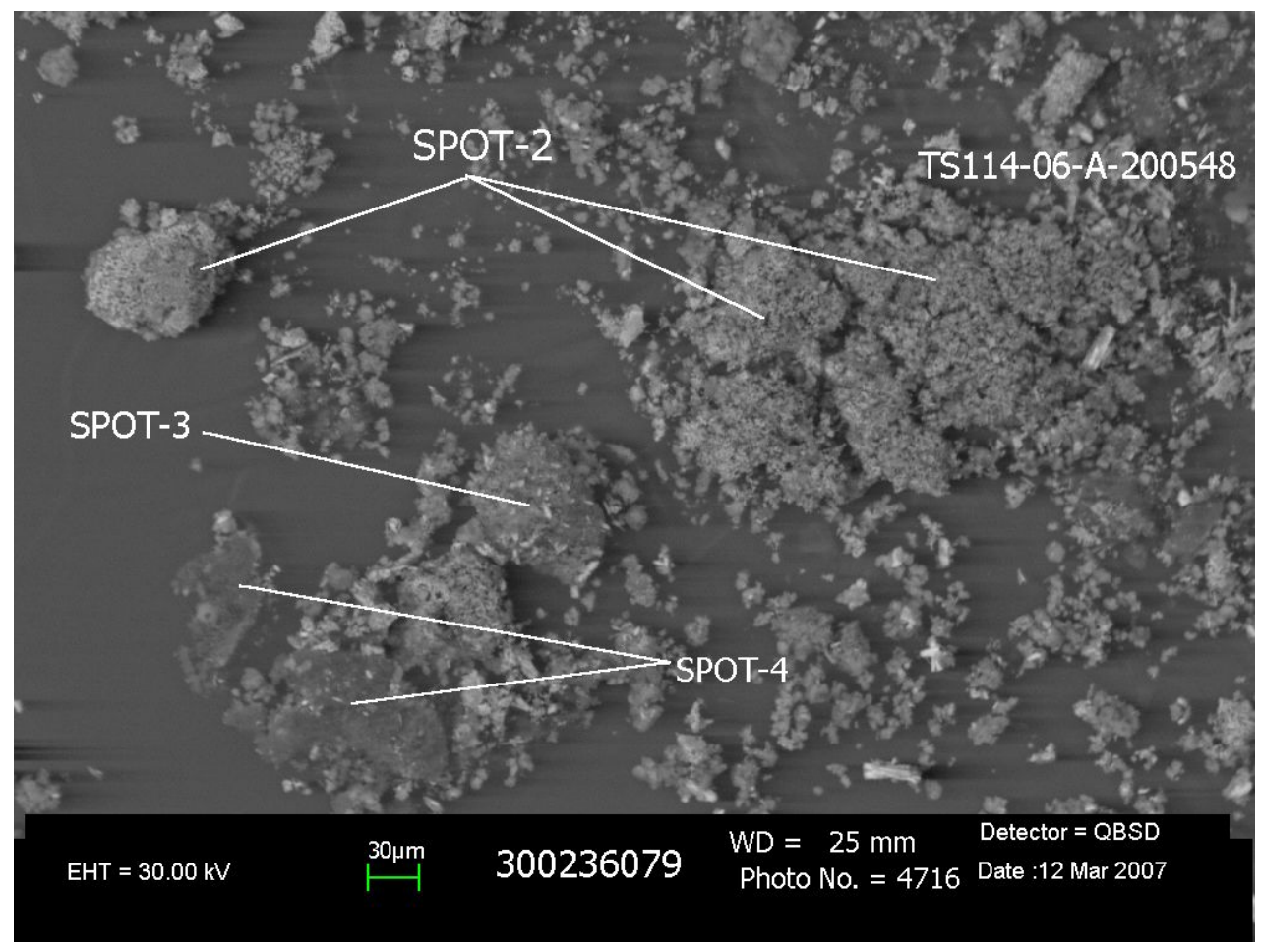

Figure 3.26 SEM Micrograph of Solids from $50^{\circ} \mathrm{C}$ Oxalic Acid Test (158X Magnification)

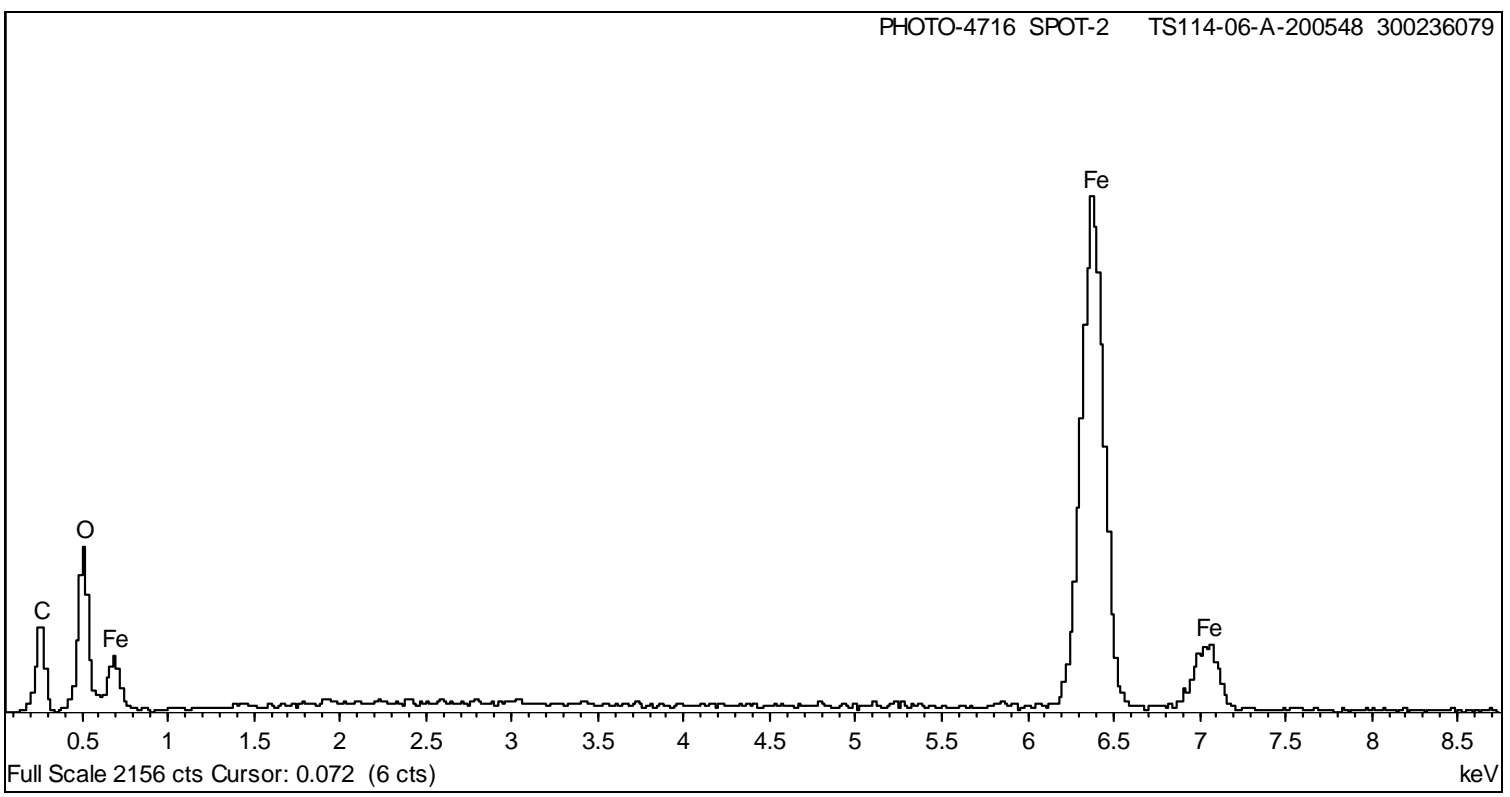

Figure 3.27 Spectrum of Spot 2 from Figure 3.26 
WSRC-STI-2007-00192, REV. 1

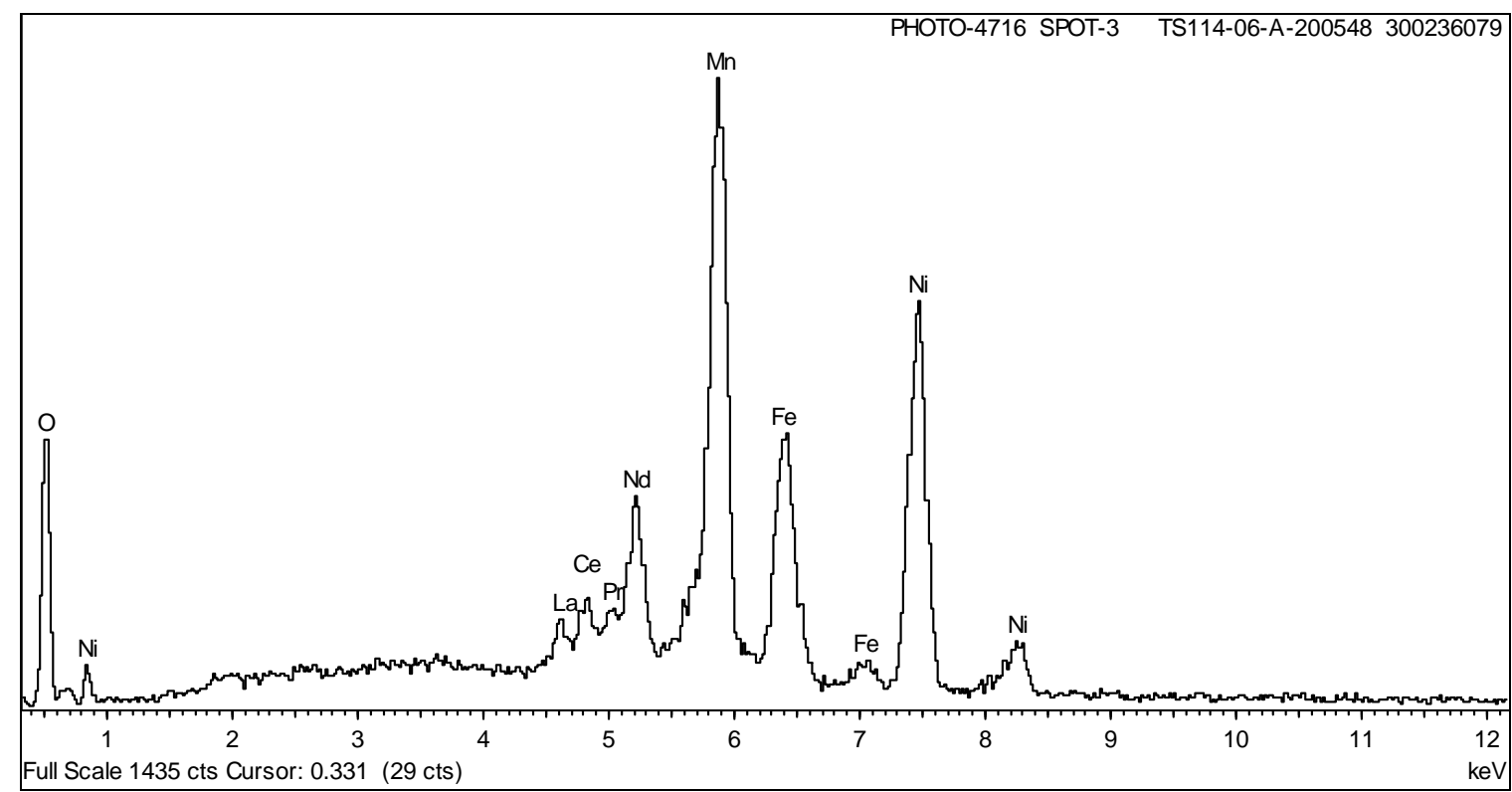

Figure 3.28 Spectrum of Spot 3 from Figure 3.26

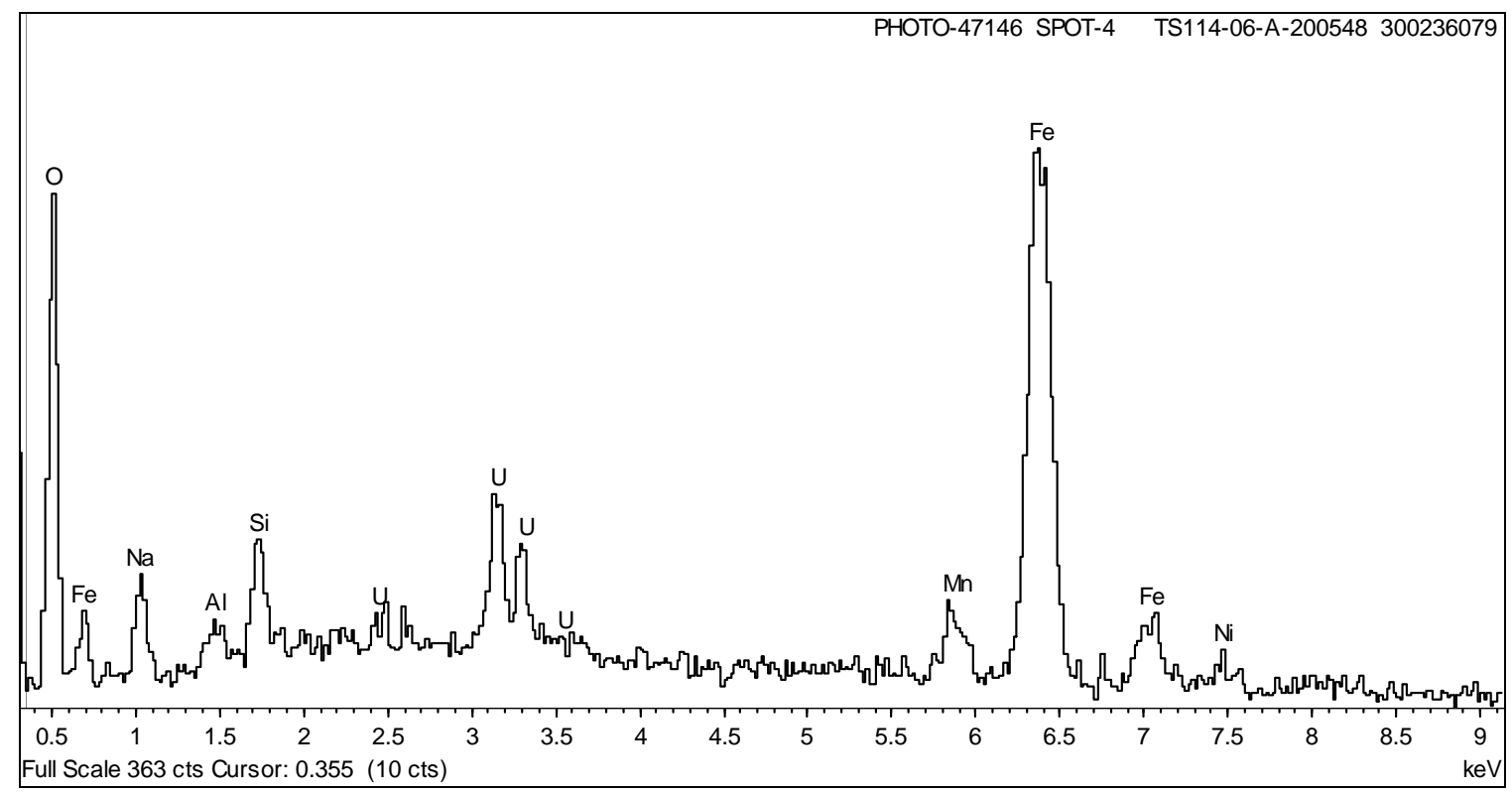

Figure 3.29 Spectrum of Spot 4 from Figure 3.26 


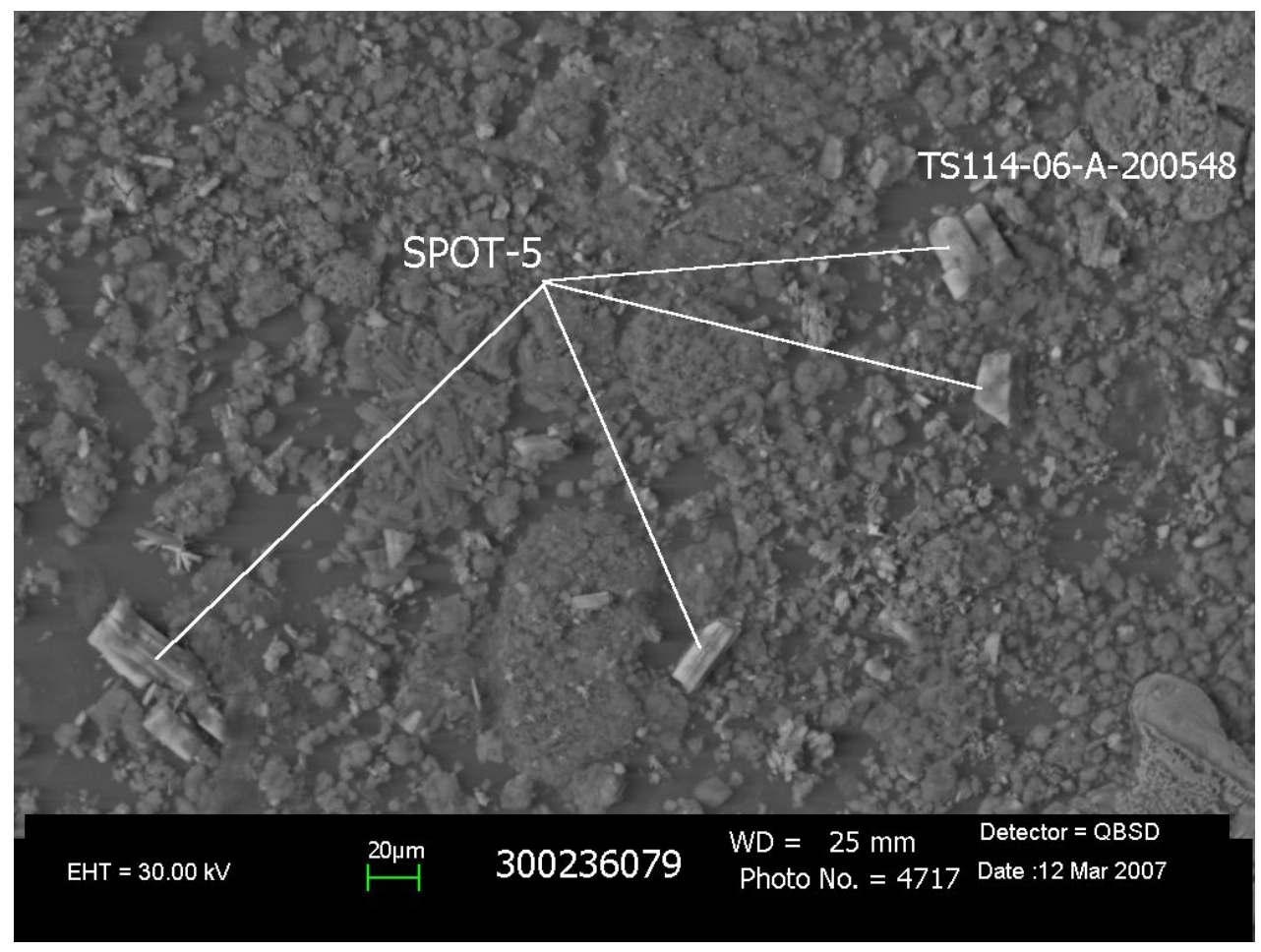

Figure 3.30 SEM Micrograph of Solids from $50^{\circ} \mathrm{C}$ Oxalic Acid Test (233X Magnification)

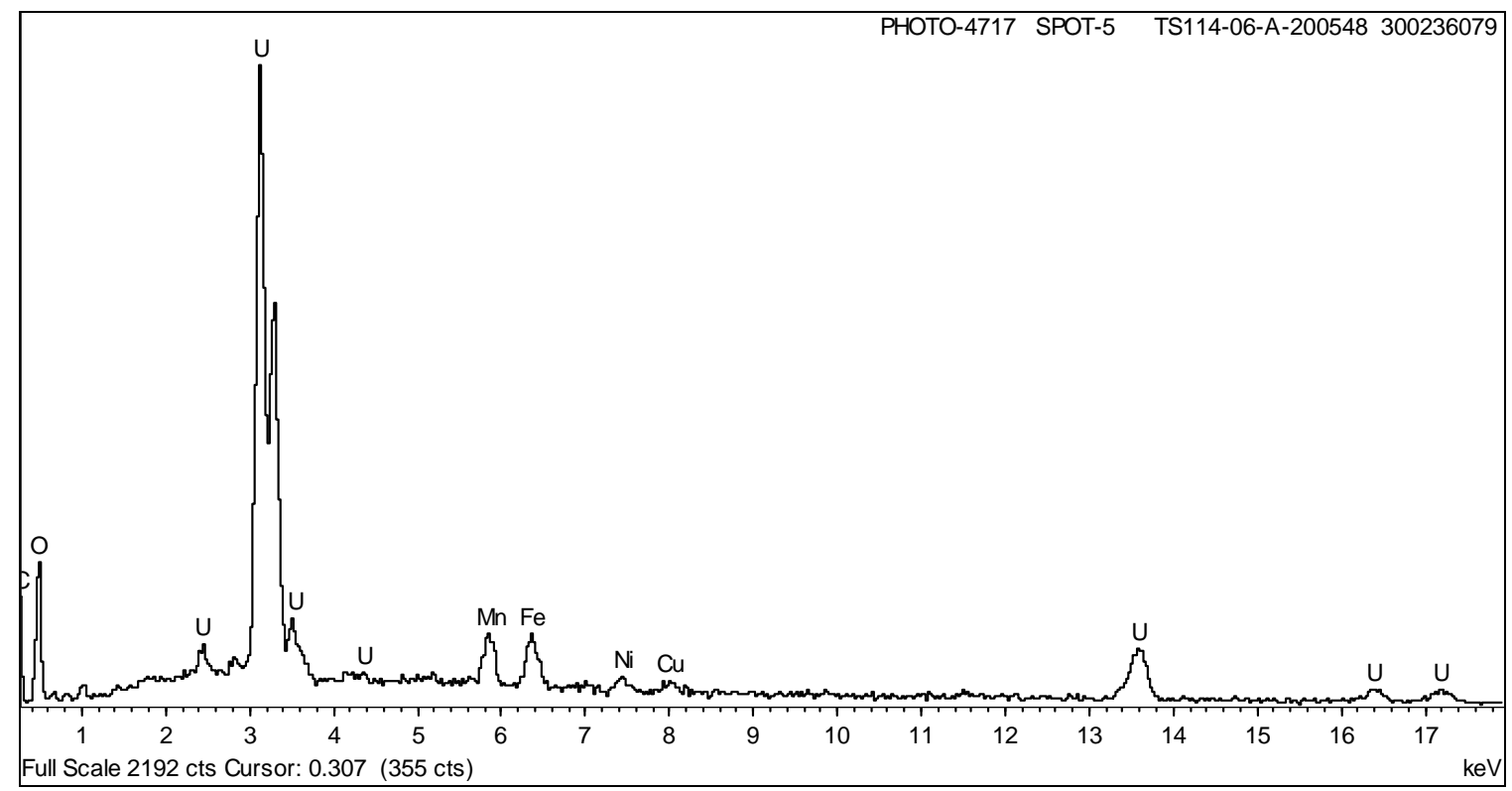

Figure 3.31 Spectrum of Spot 5 from Figure 3.30 


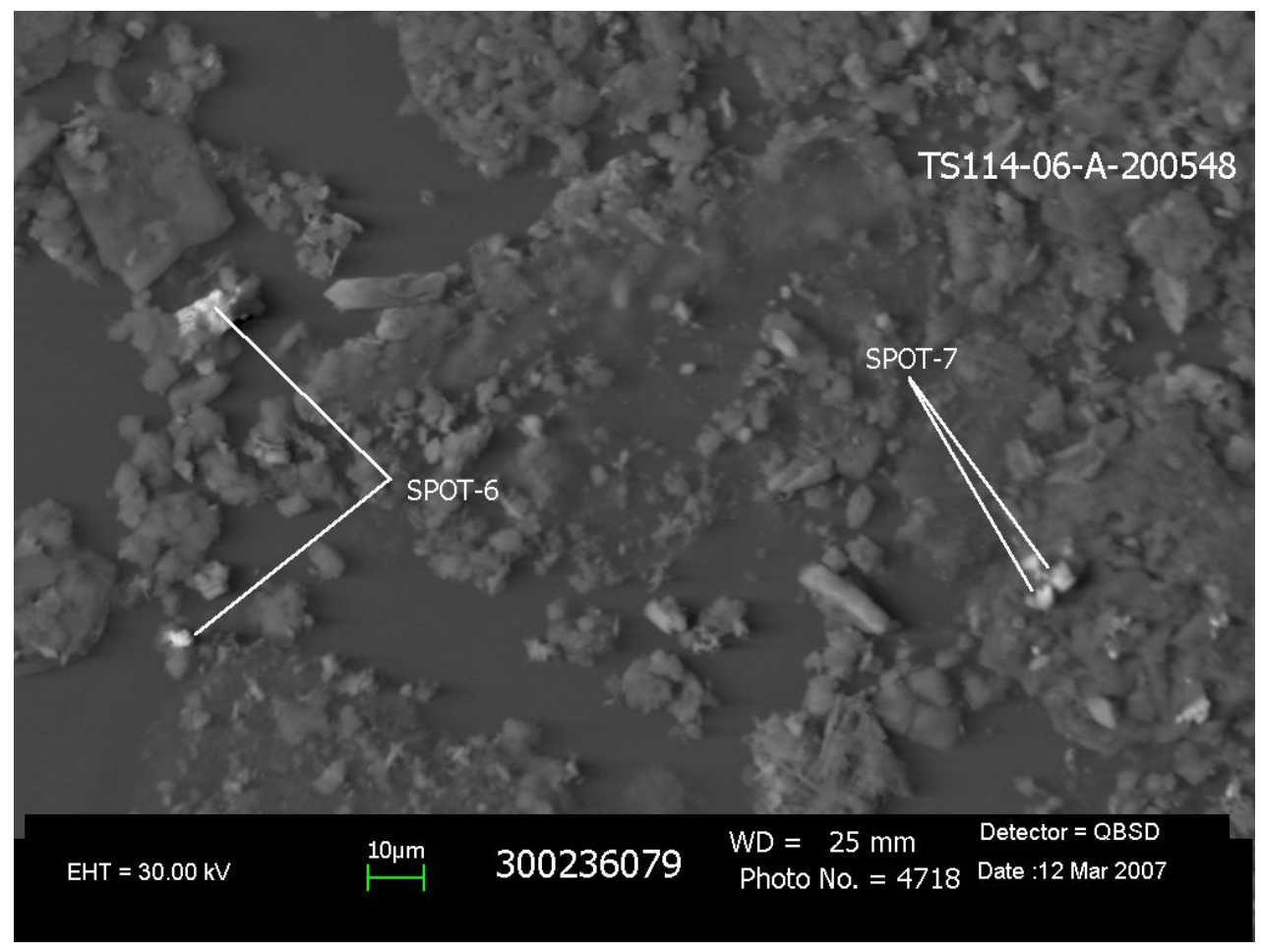

Figure 3.32 SEM Micrograph of Solids from $50^{\circ} \mathrm{C}$ Oxalic Acid Test (512X Magnification)

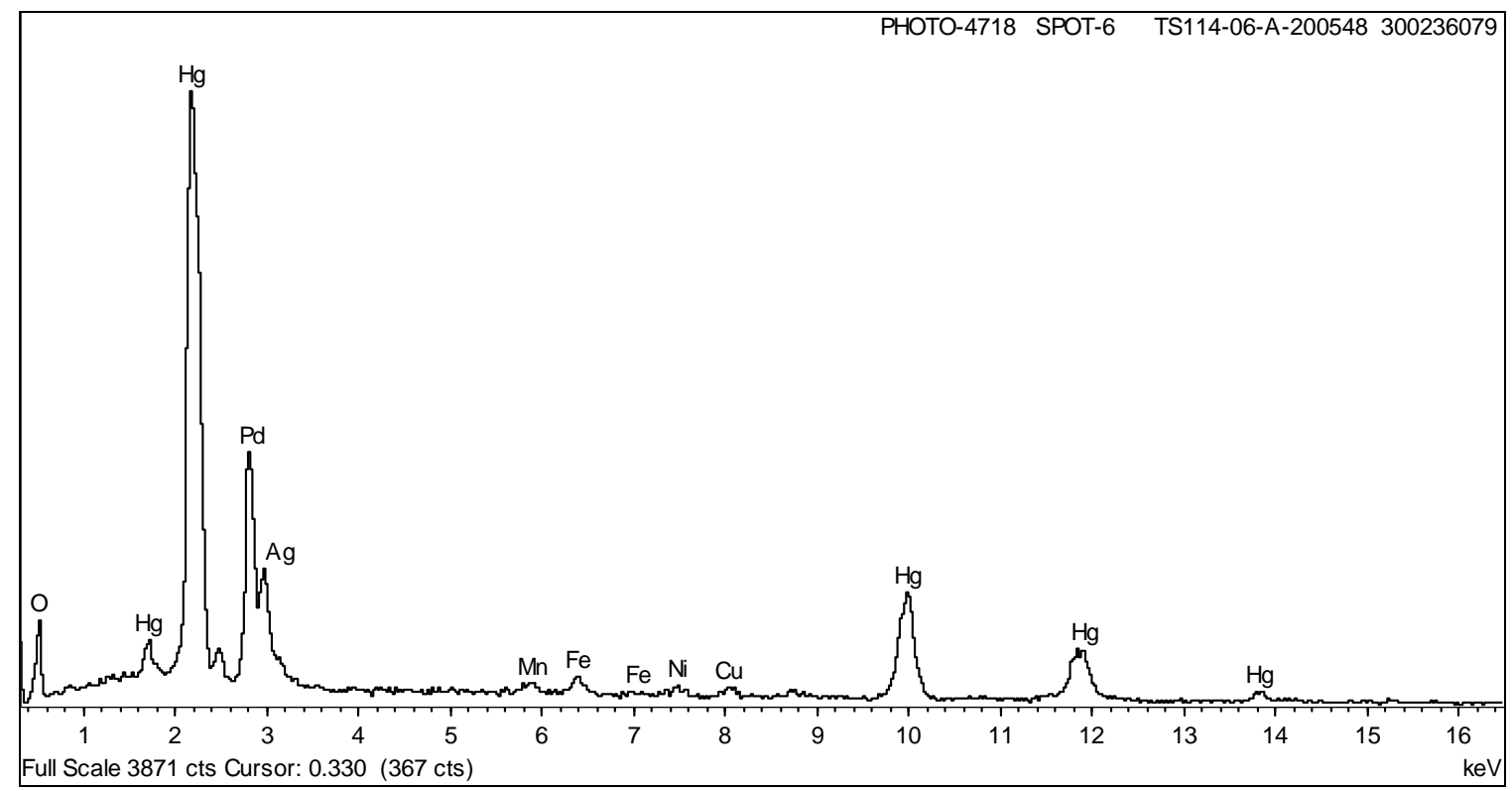

Figure 3.33 Spectrum of Spot 6 from Figure 3.32 
WSRC-STI-2007-00192, REV. 1

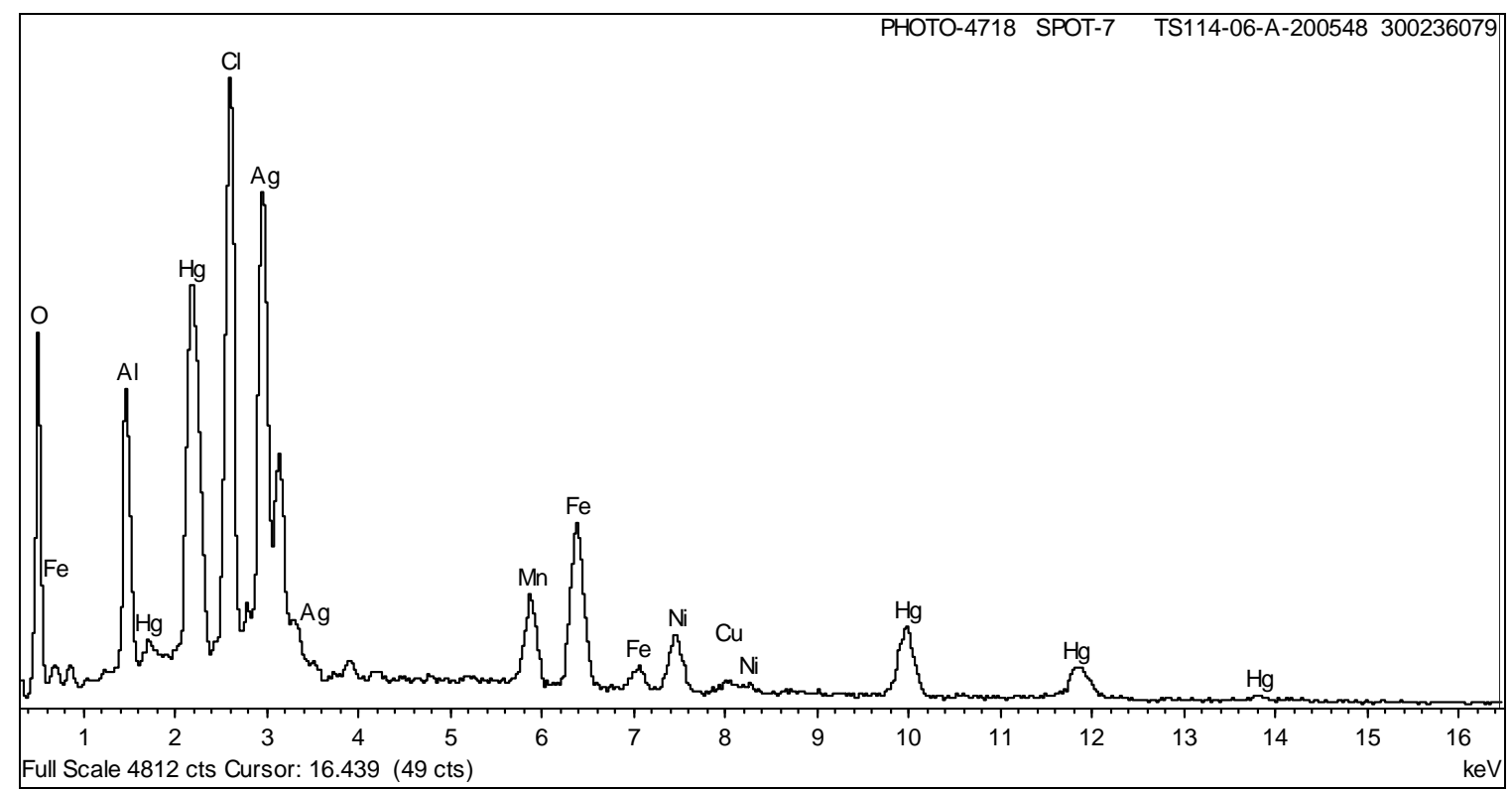

Figure 3.34 Spectrum of Spot 7 from Figure 3.32 


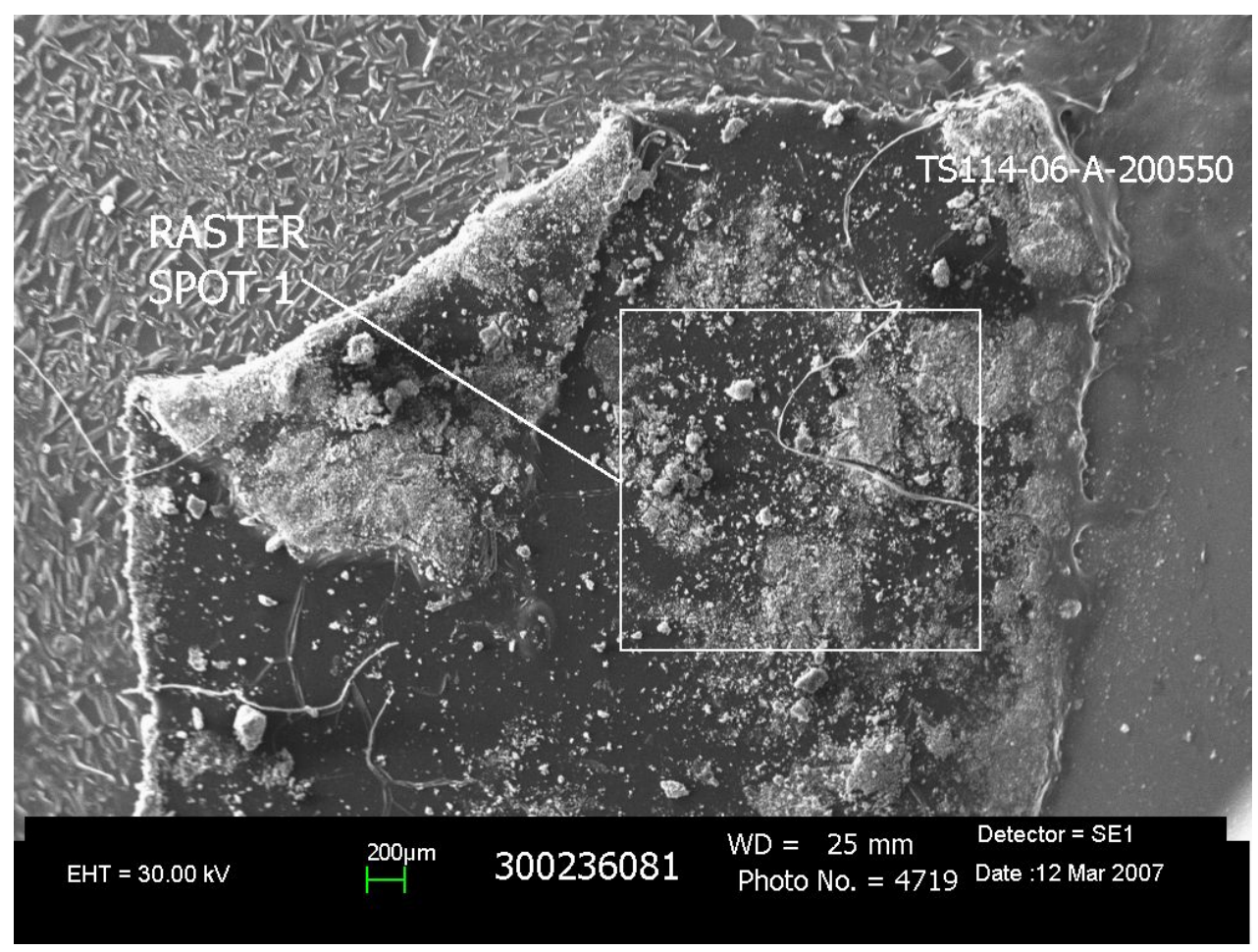

Figure 3.35 SEM Micrograph of Solids from $75^{\circ} \mathrm{C}$ Oxalic Acid Test (18X Magnification)

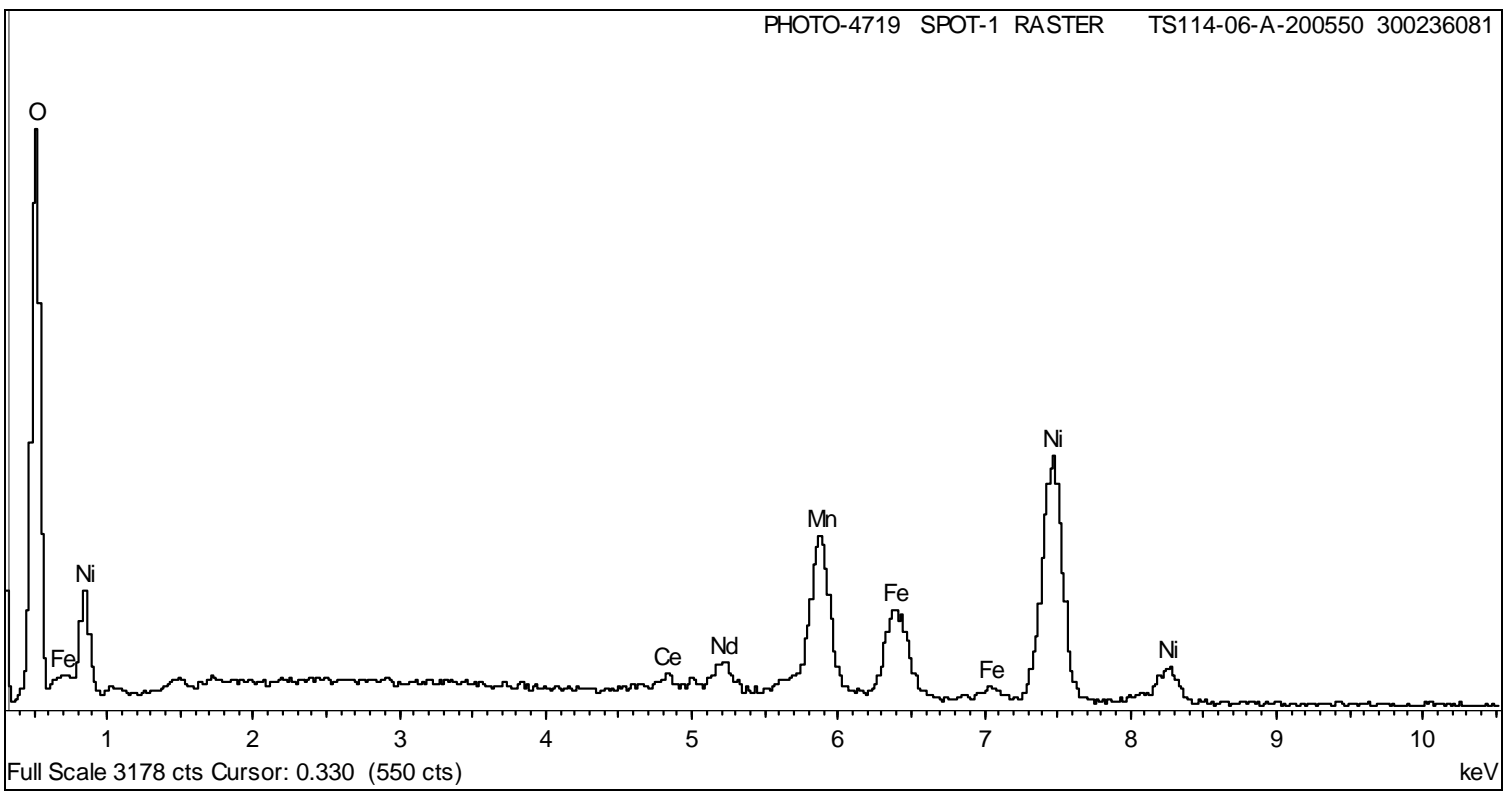

Figure 3.36 Spectrum of Spot 1 from Figure 3.35 


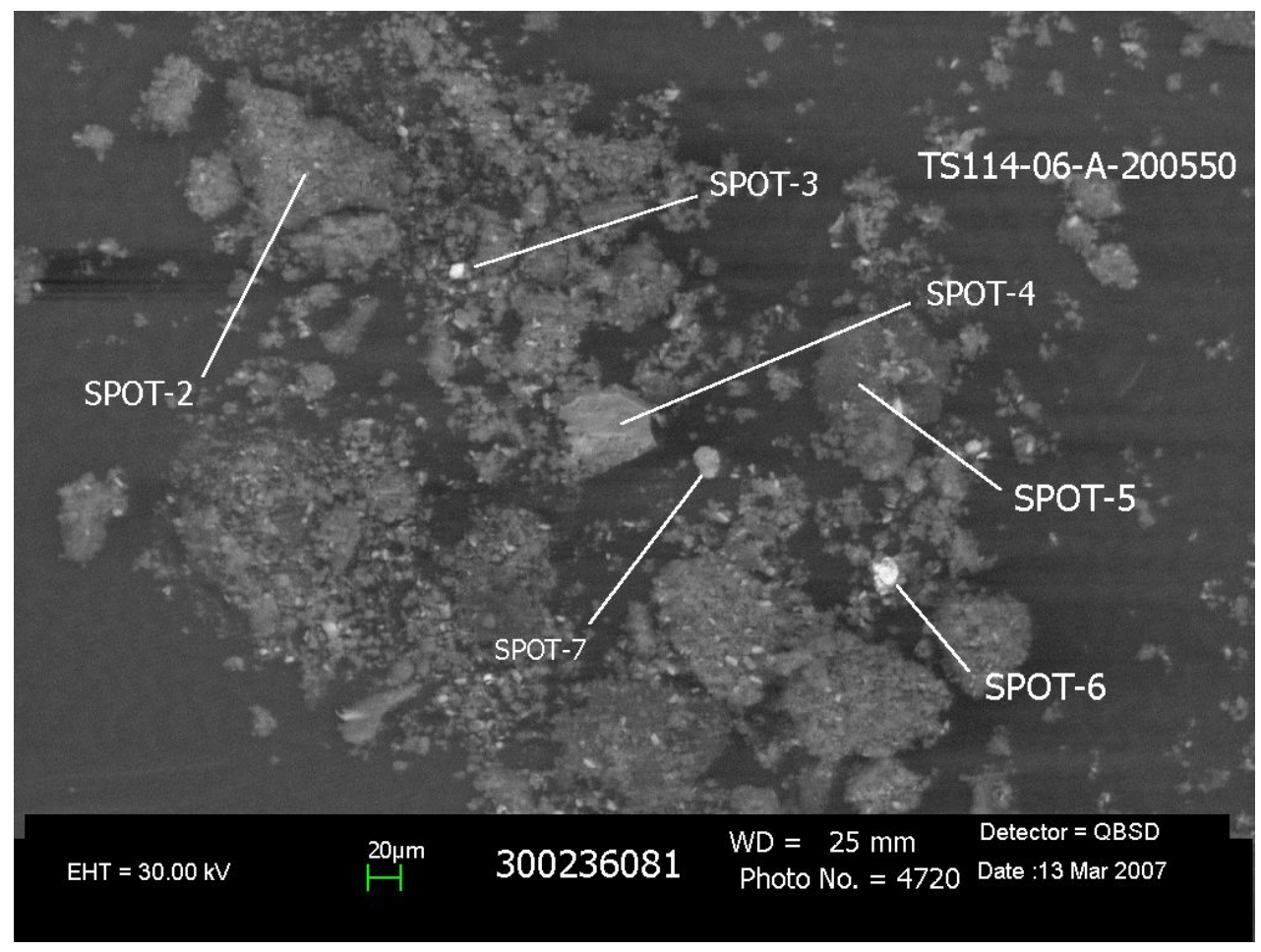

Figure 3.37 SEM Micrograph of Solids from $75{ }^{\circ} \mathrm{C}$ Oxalic Acid Test (118X Magnification)

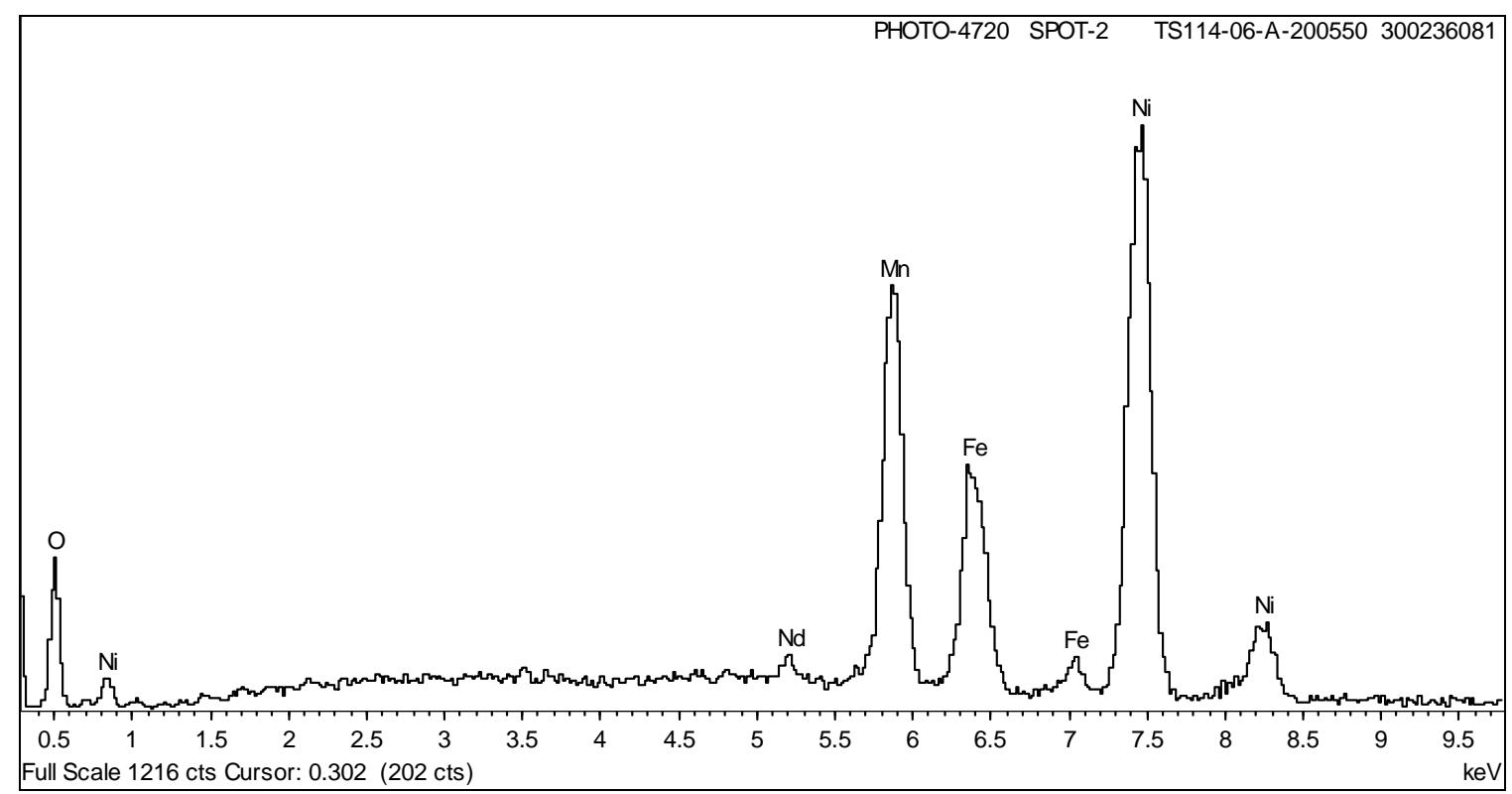

Figure 3.38 Spectrum of Spot 2 from Figure 3.37 


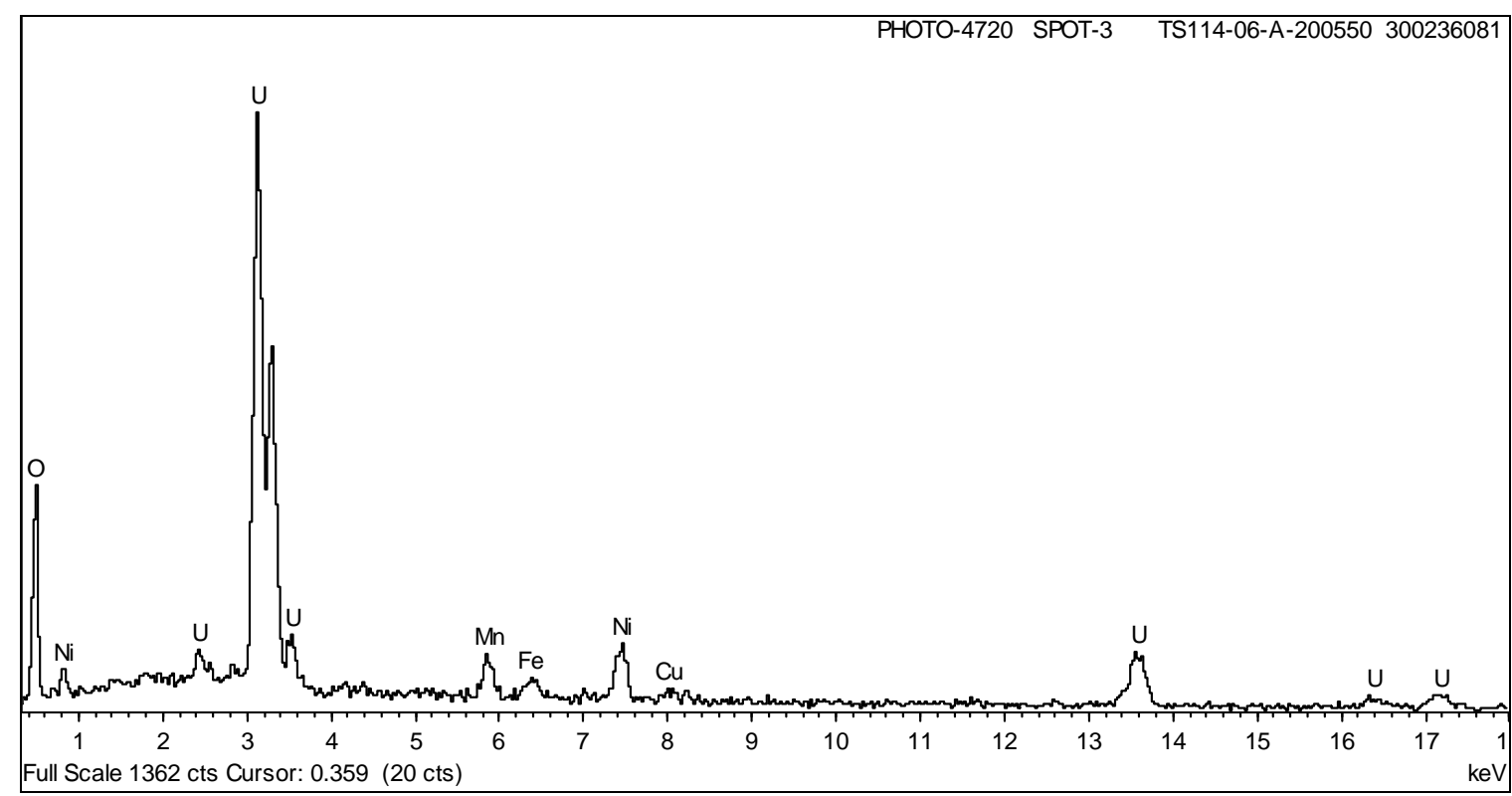

Figure 3.39 Spectrum of Spot 3 from Figure 3.37

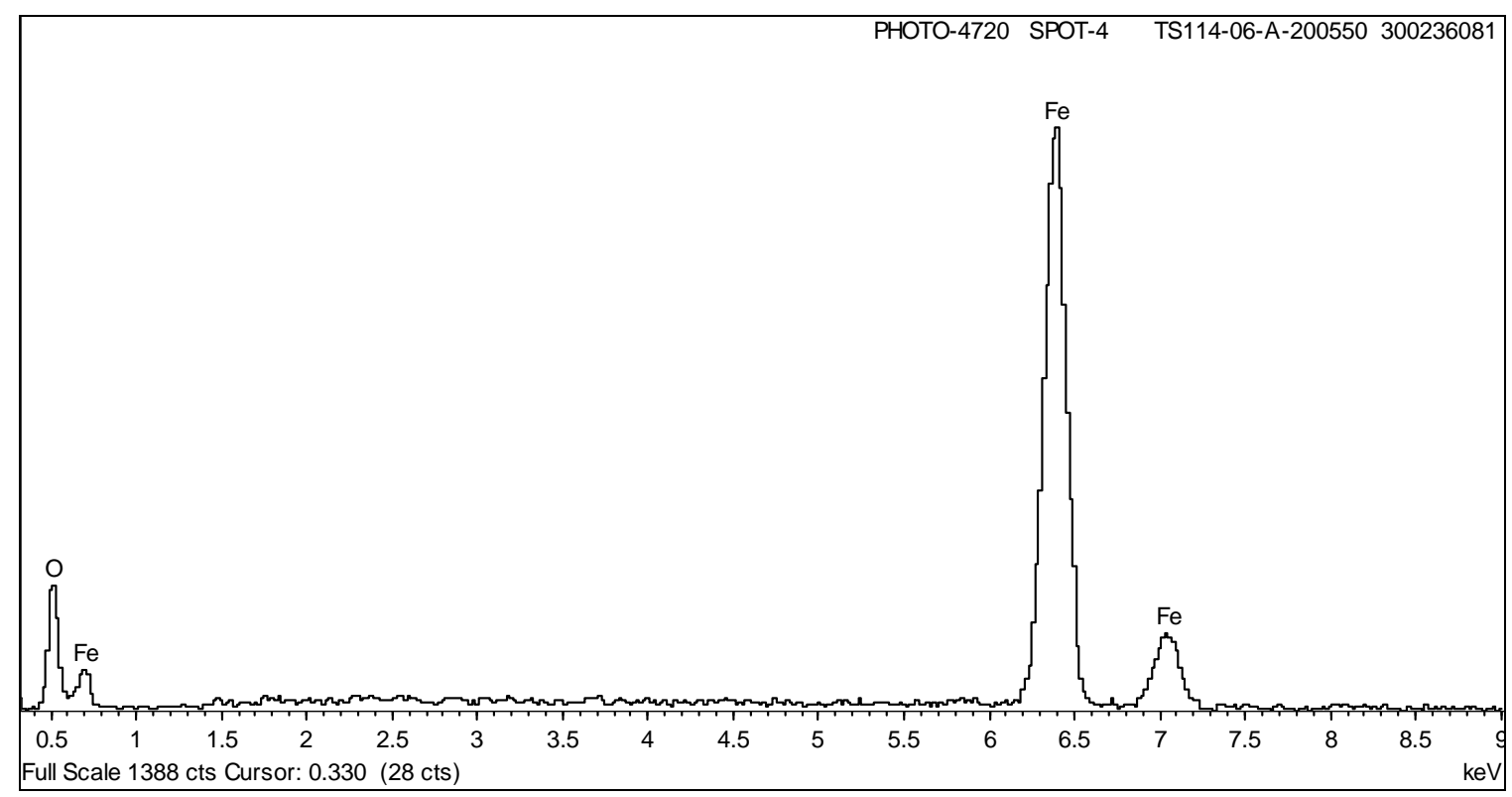

Figure 3.40 Spectrum of Spot 4 from Figure 3.37 
WSRC-STI-2007-00192, REV. 1

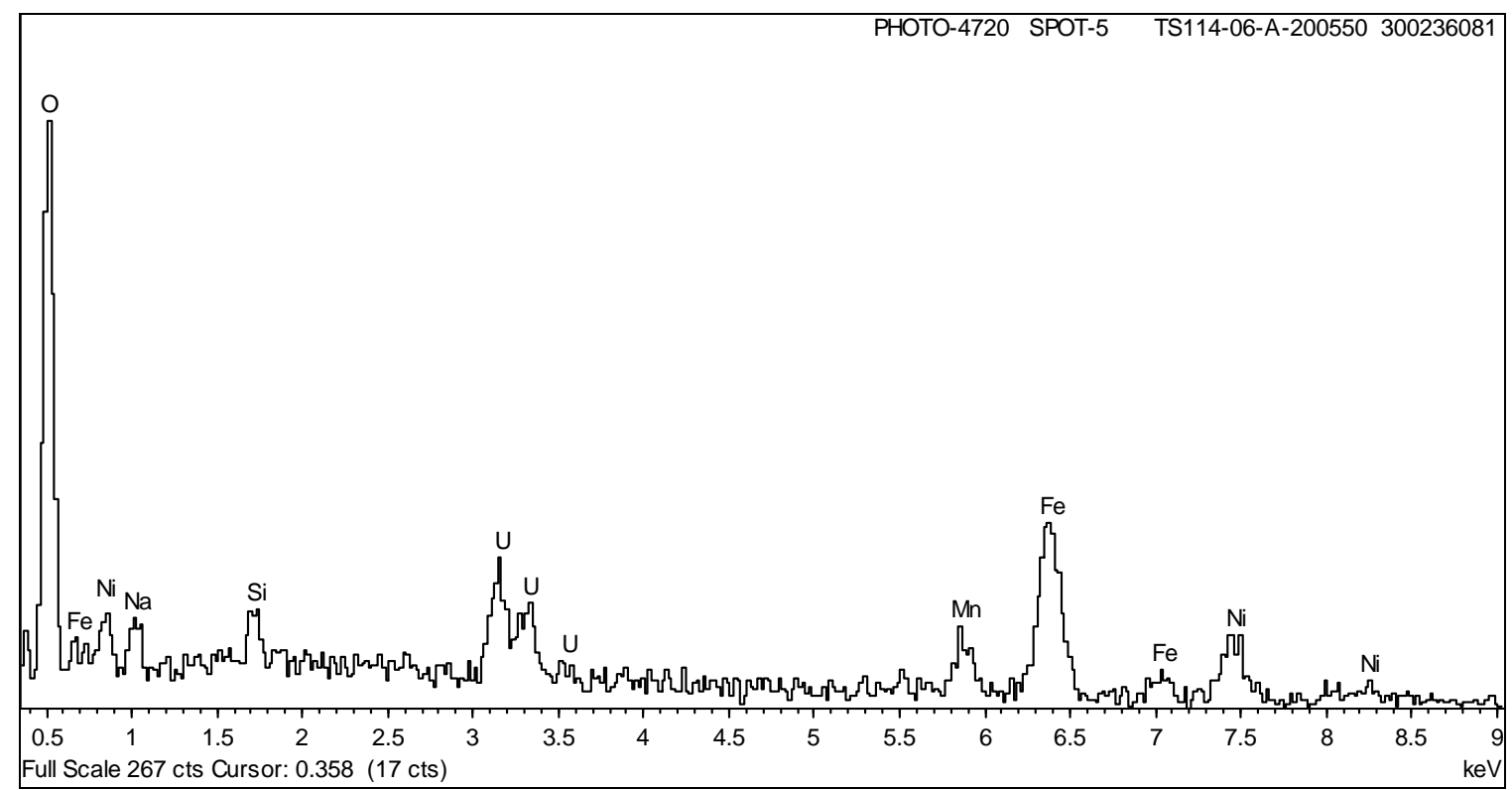

Figure 3.41 Spectrum of Spot 5 from Figure 3.37

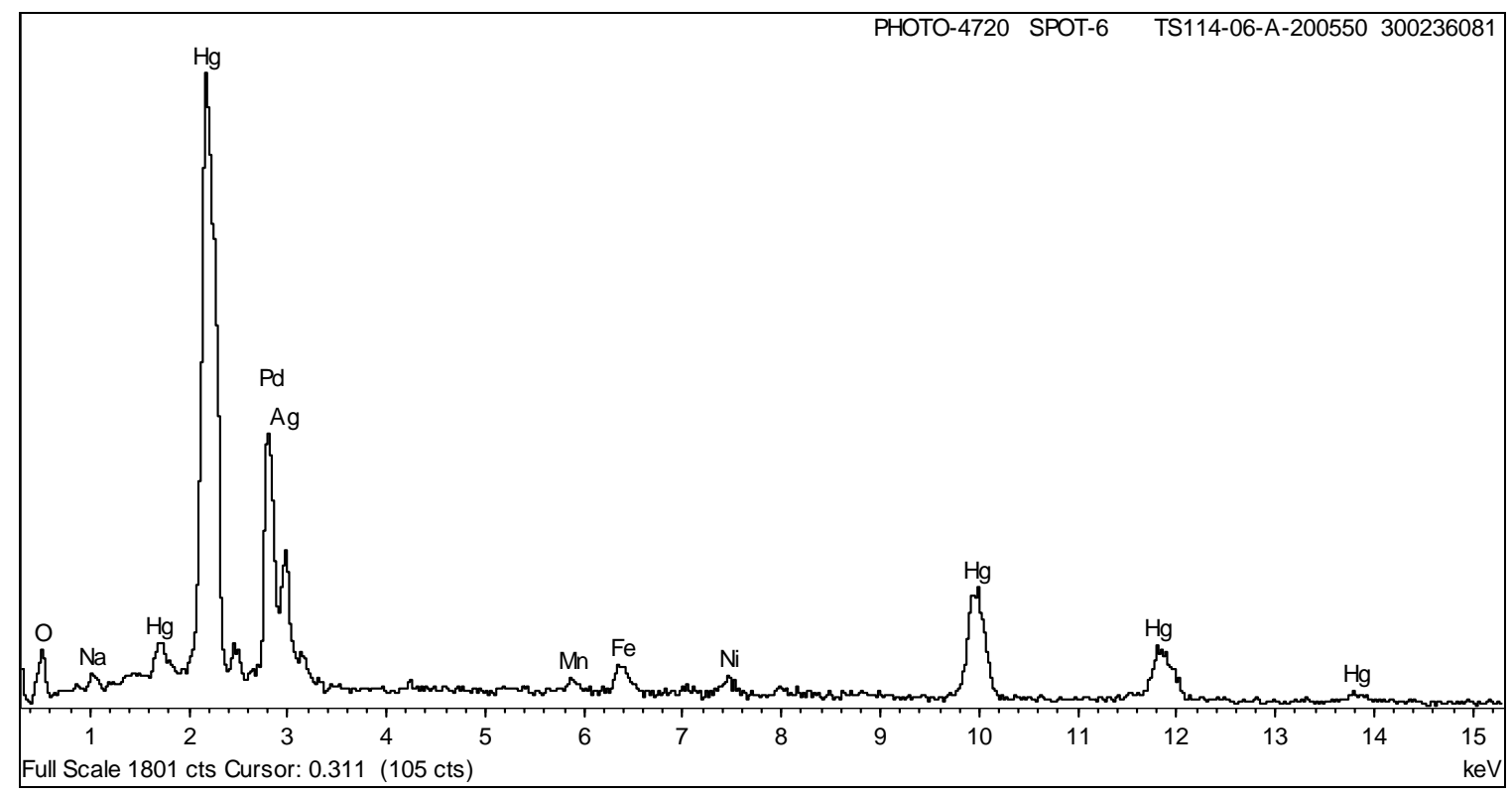

Figure 3.42 Spectrum of Spot 6 from Figure 3.37 
WSRC-STI-2007-00192, REV. 1

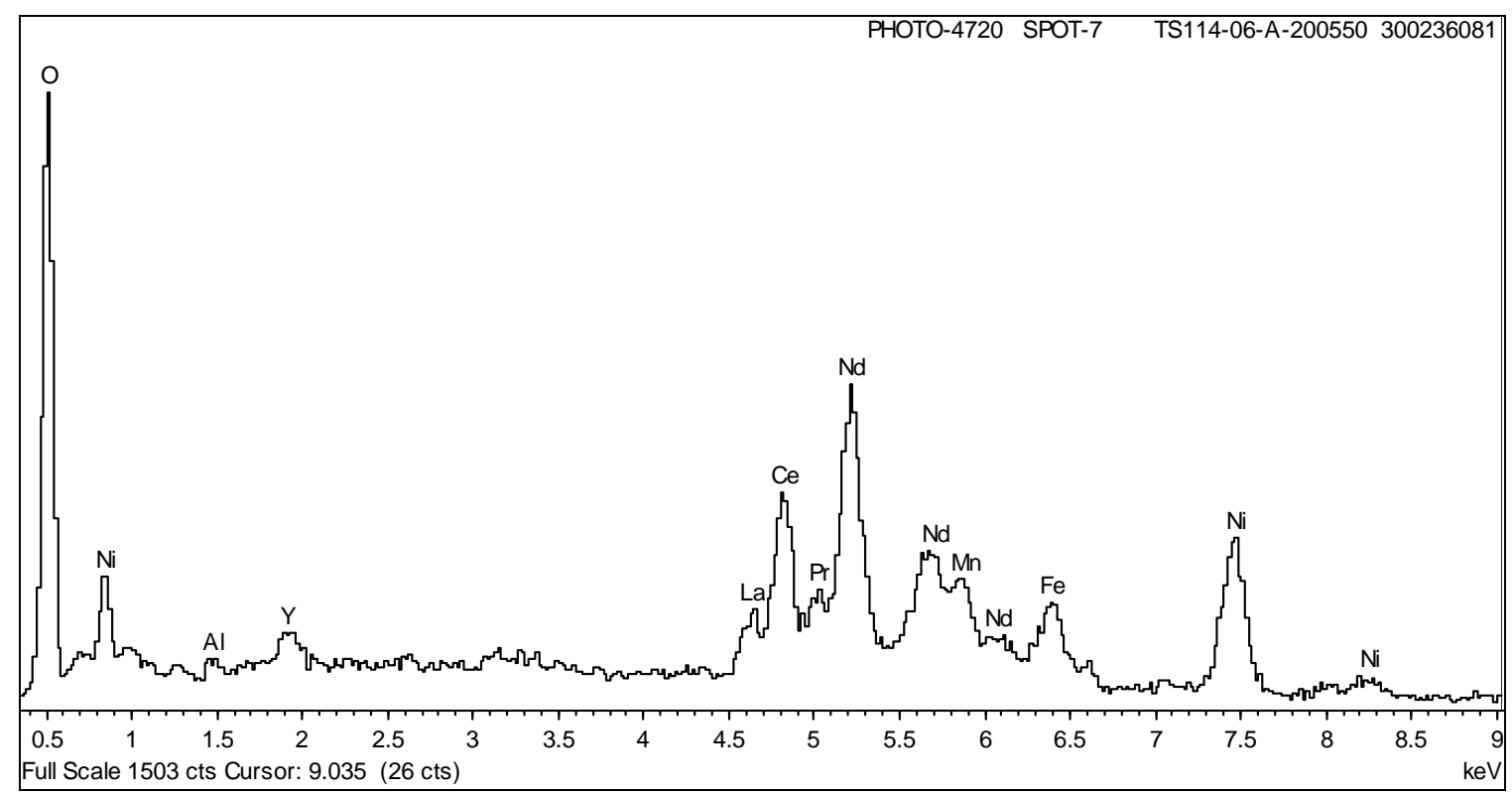

Figure 3.43 Spectrum of Spot 7 from Figure 3.37

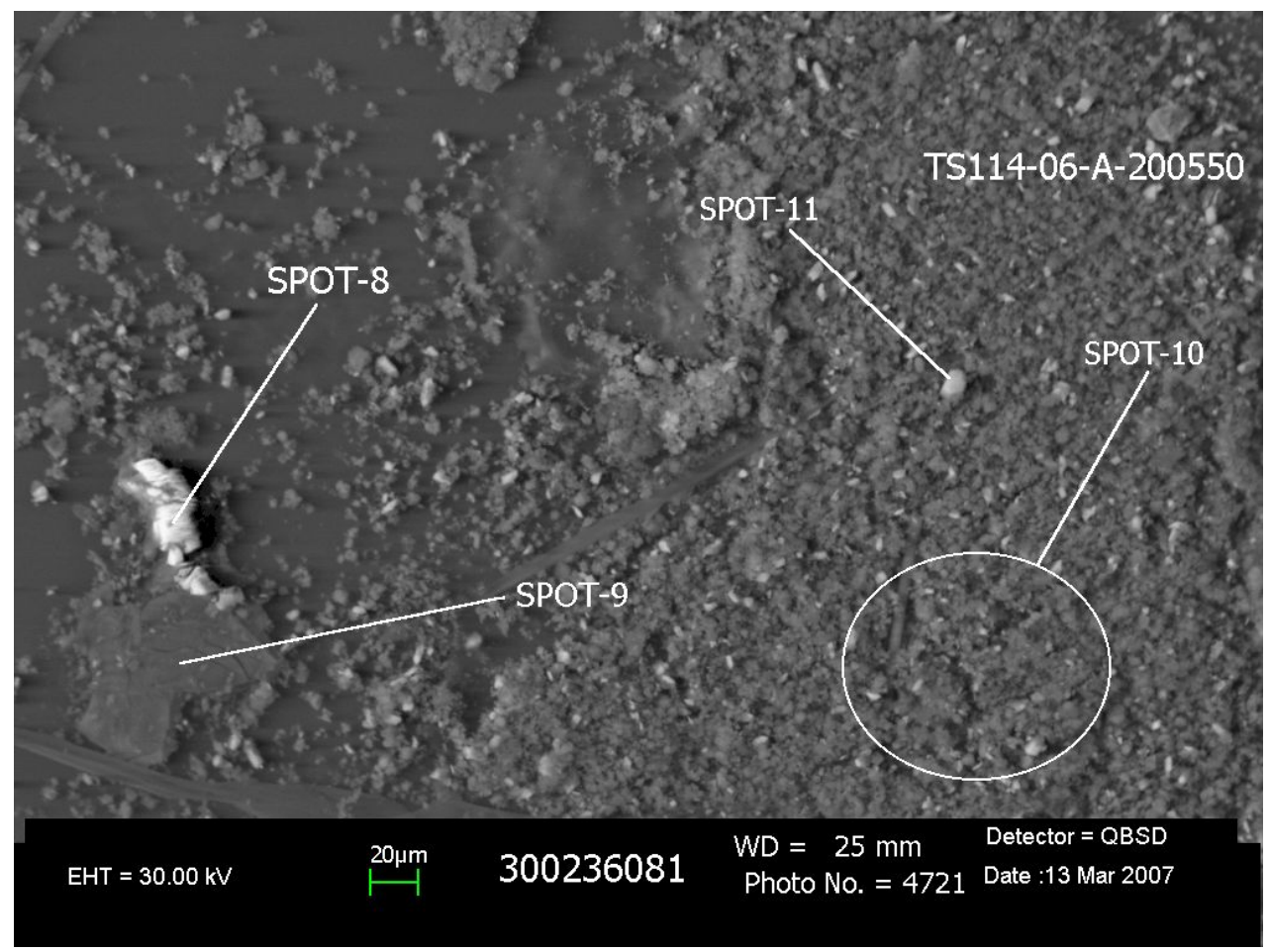

Figure 3.44 SEM Micrograph of Solids from $75{ }^{\circ} \mathrm{C}$ Oxalic Acid Test (215X Magnification) 
WSRC-STI-2007-00192, REV. 1

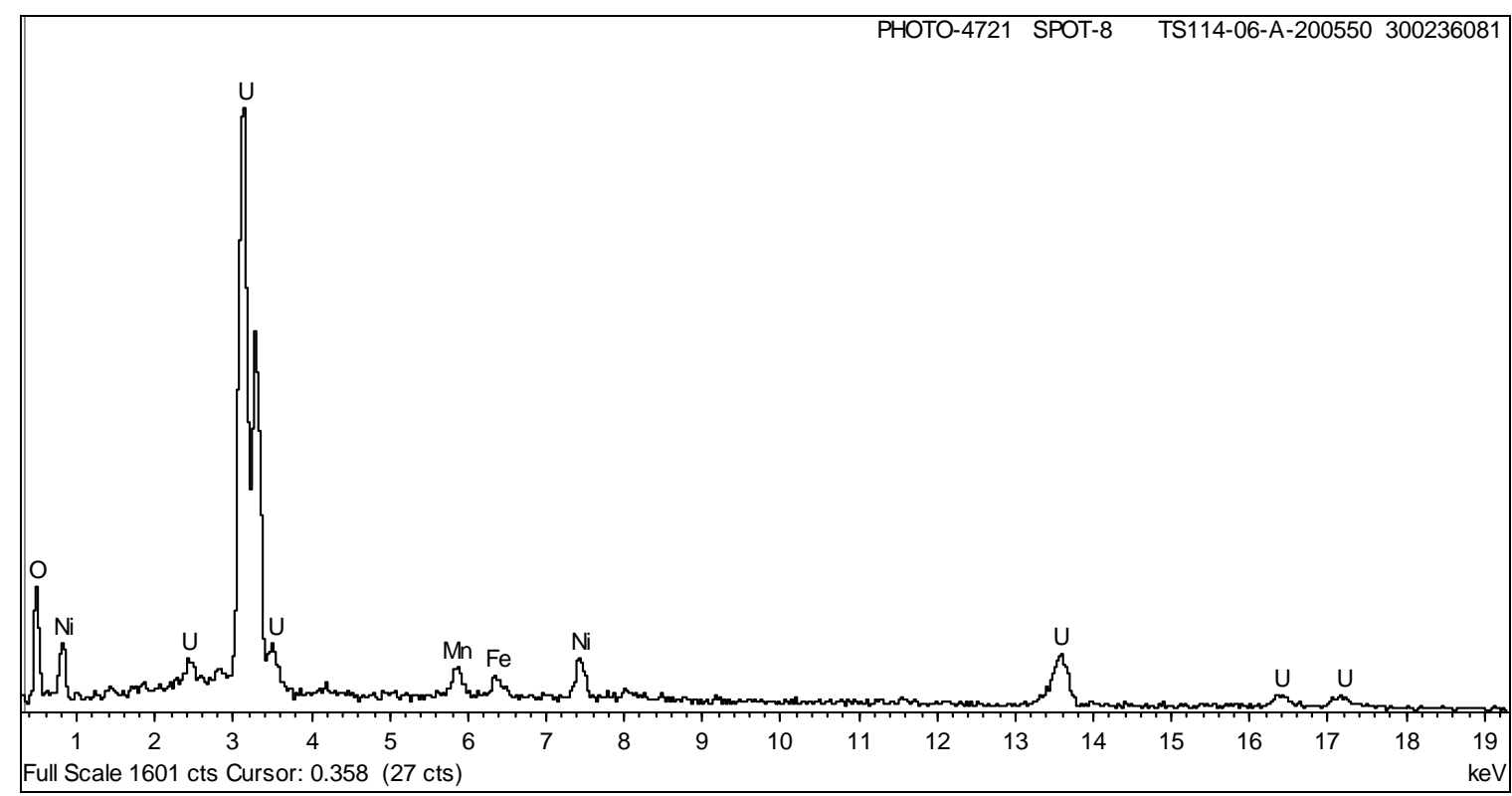

Figure 3.45 Spectrum of Spot 8 from Figure 3.44

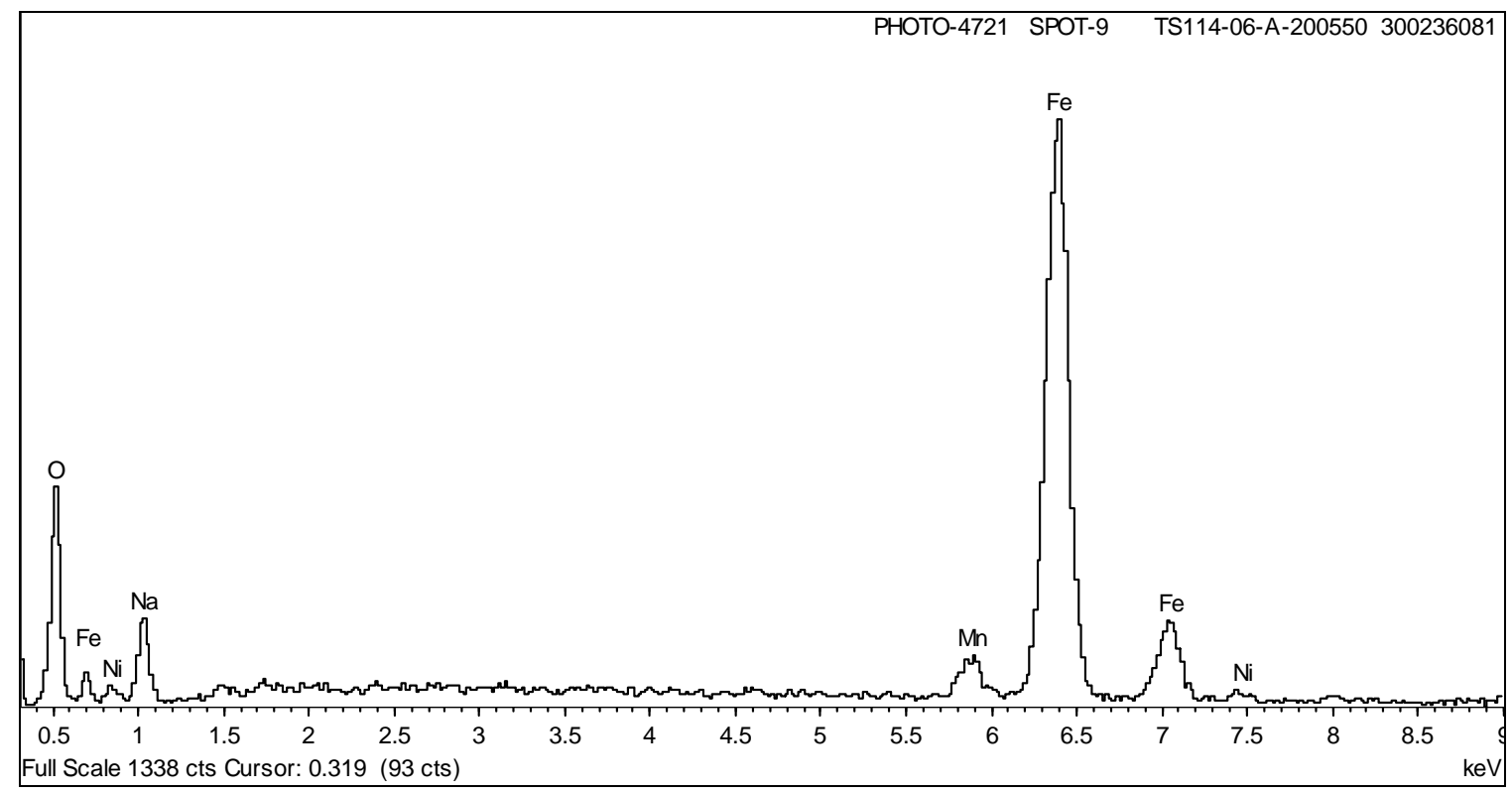

Figure 3.46 Spectrum of Spot 9 from Figure 3.44 


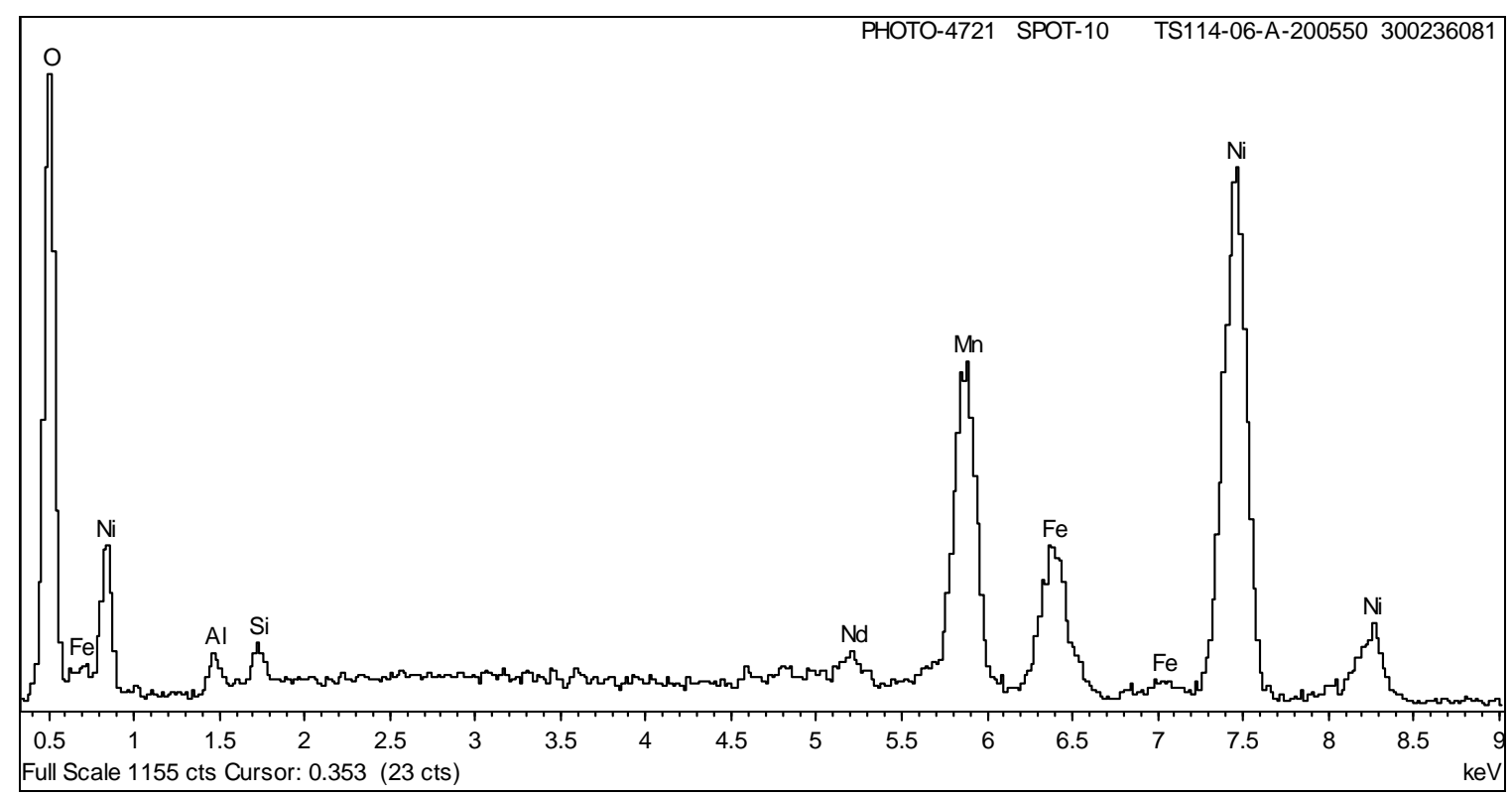

Figure 3.47 Spectrum of Spot 10 from Figure 3.44

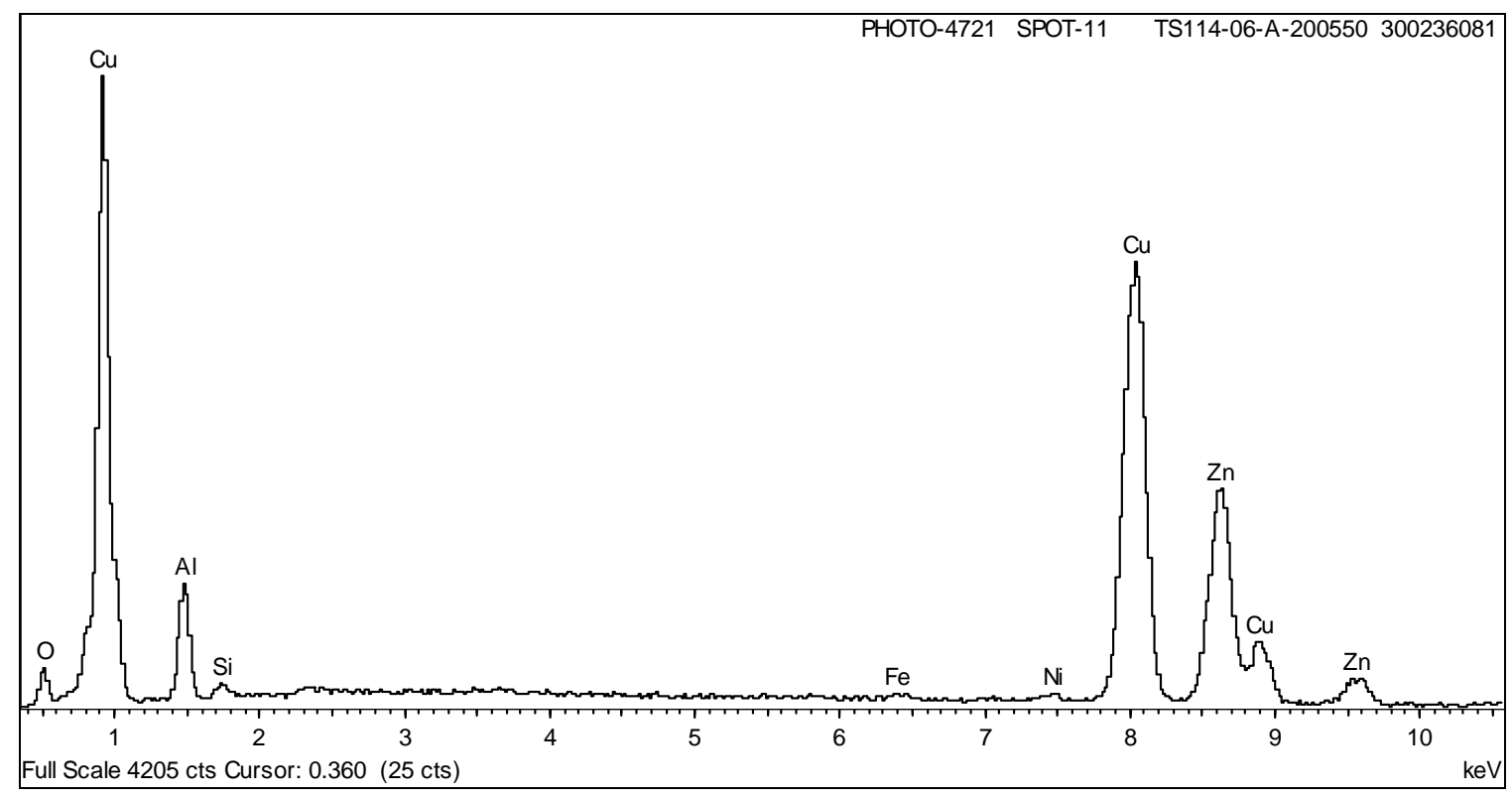

Figure 3.48 Spectrum of Spot 11 from Figure 3.44 


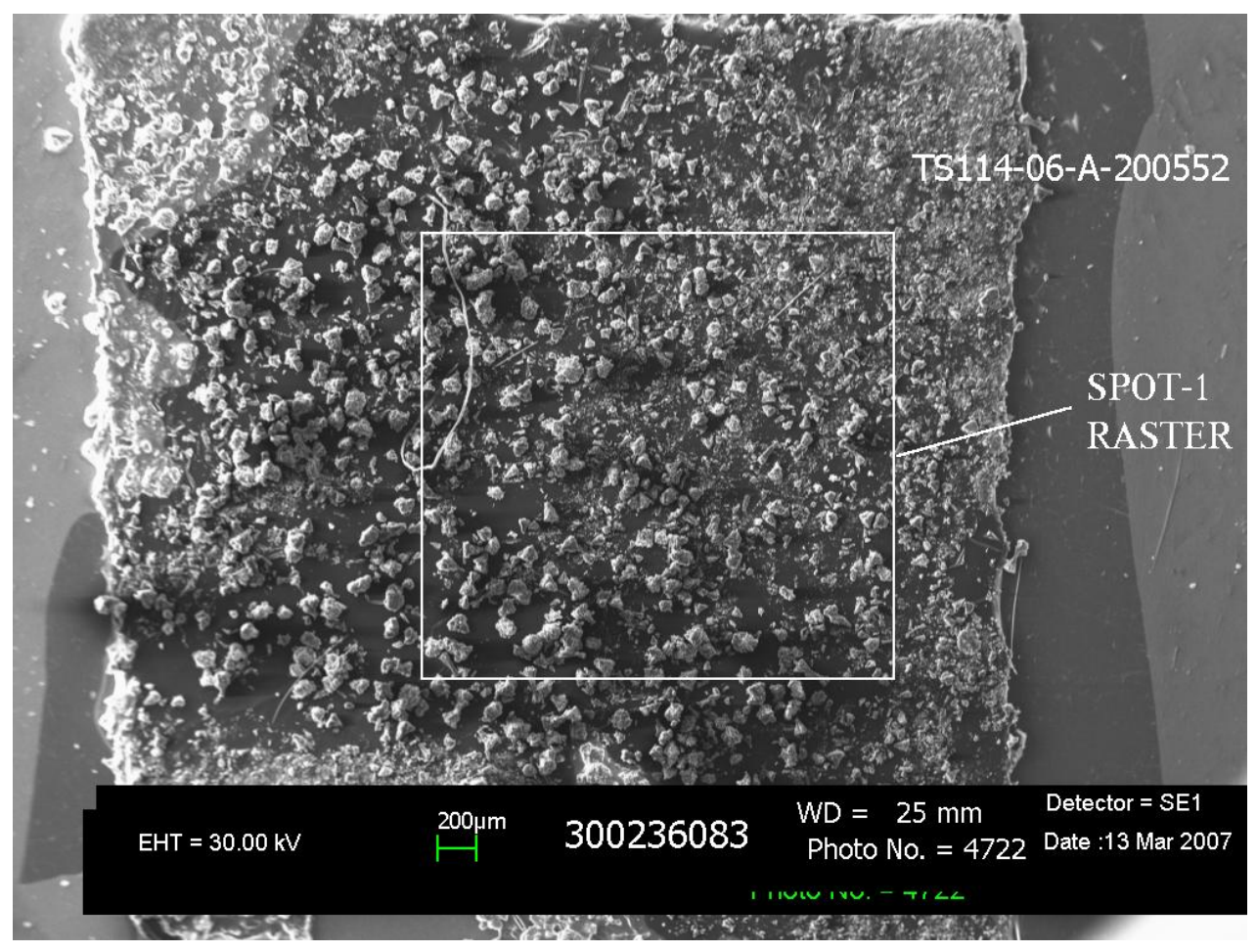

Figure 3.49 SEM Micrograph of Solids from $50{ }^{\circ} \mathrm{C}$ Neutralization Test (18X Magnification)

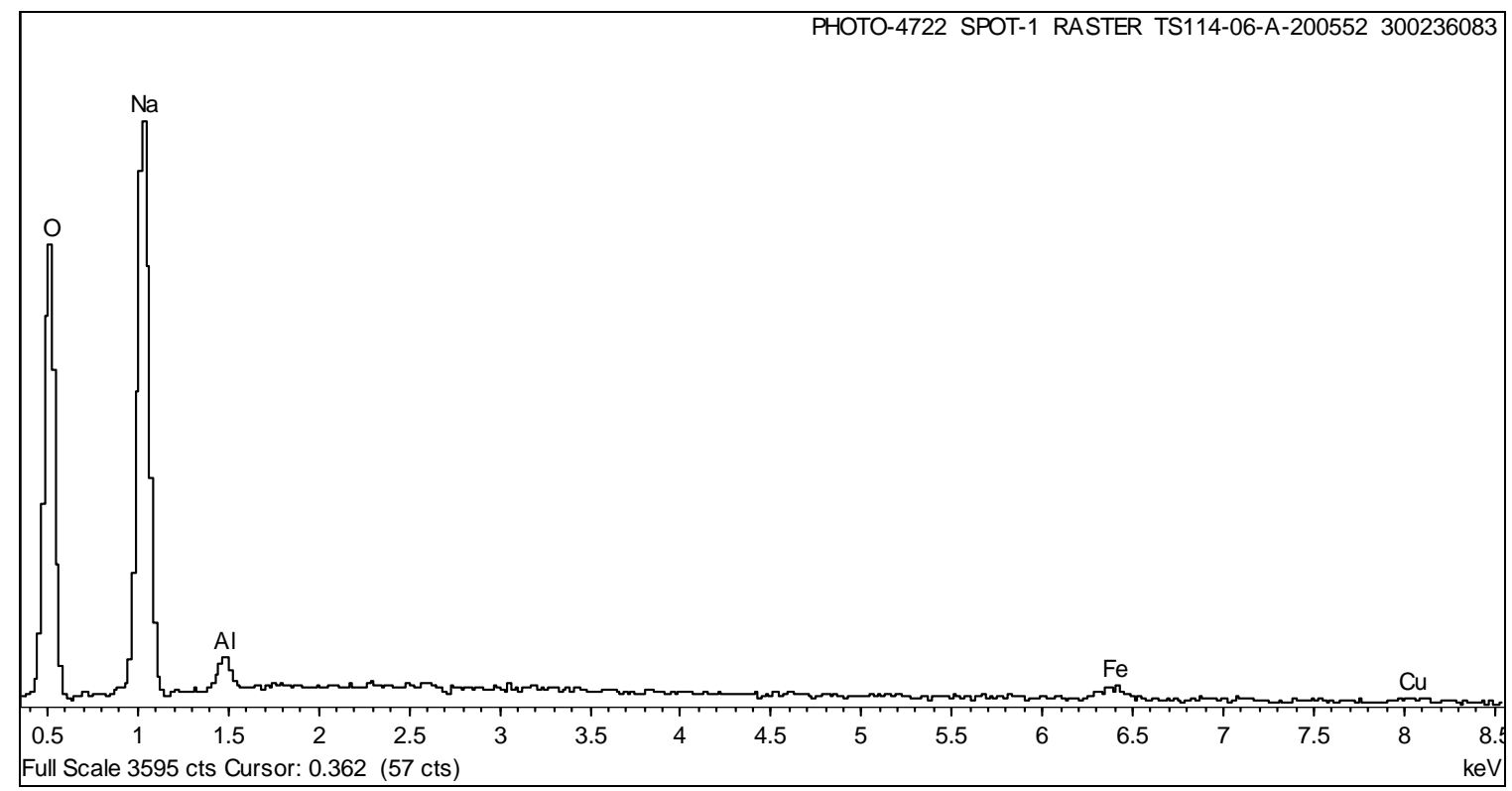

Figure 3.50 Spectrum of Spot 1 from Figure 3.49 


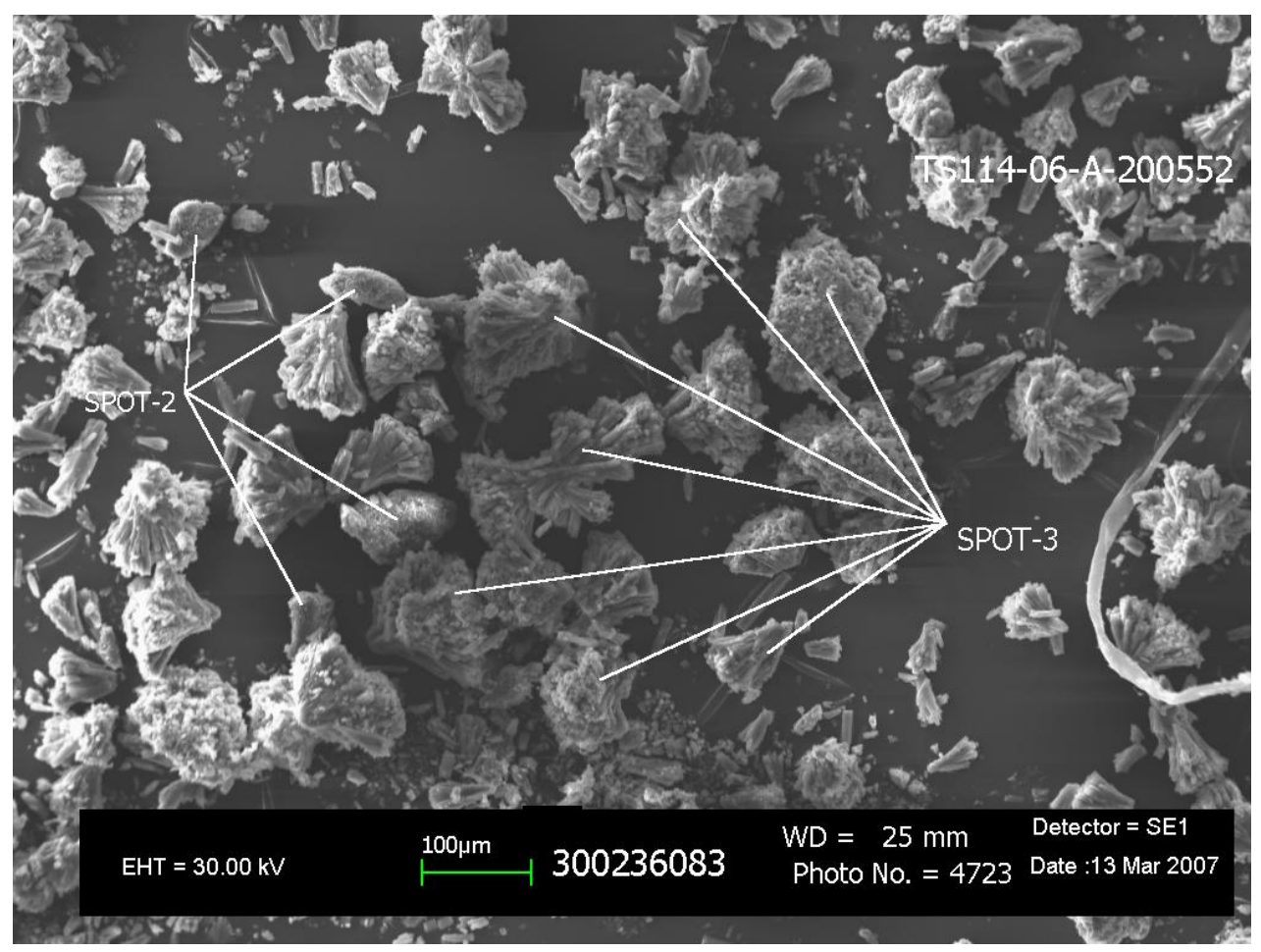

Figure 3.51 SEM Micrograph of Solids from $50^{\circ} \mathrm{C}$ Neutralization Test (100X Magnification)

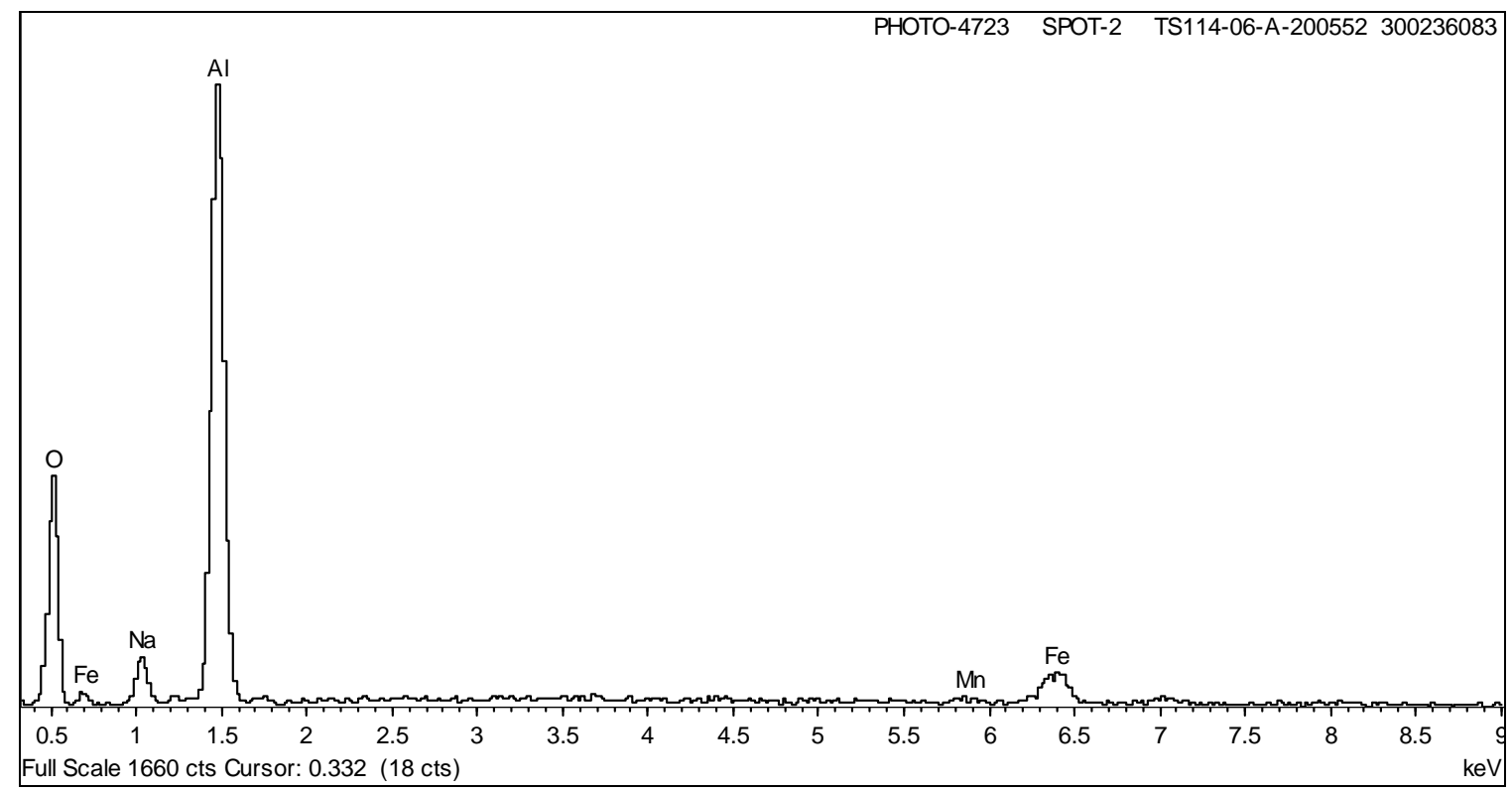

Figure 3.52 Spectrum of Spot 2 from Figure 3.51 
WSRC-STI-2007-00192, REV. 1

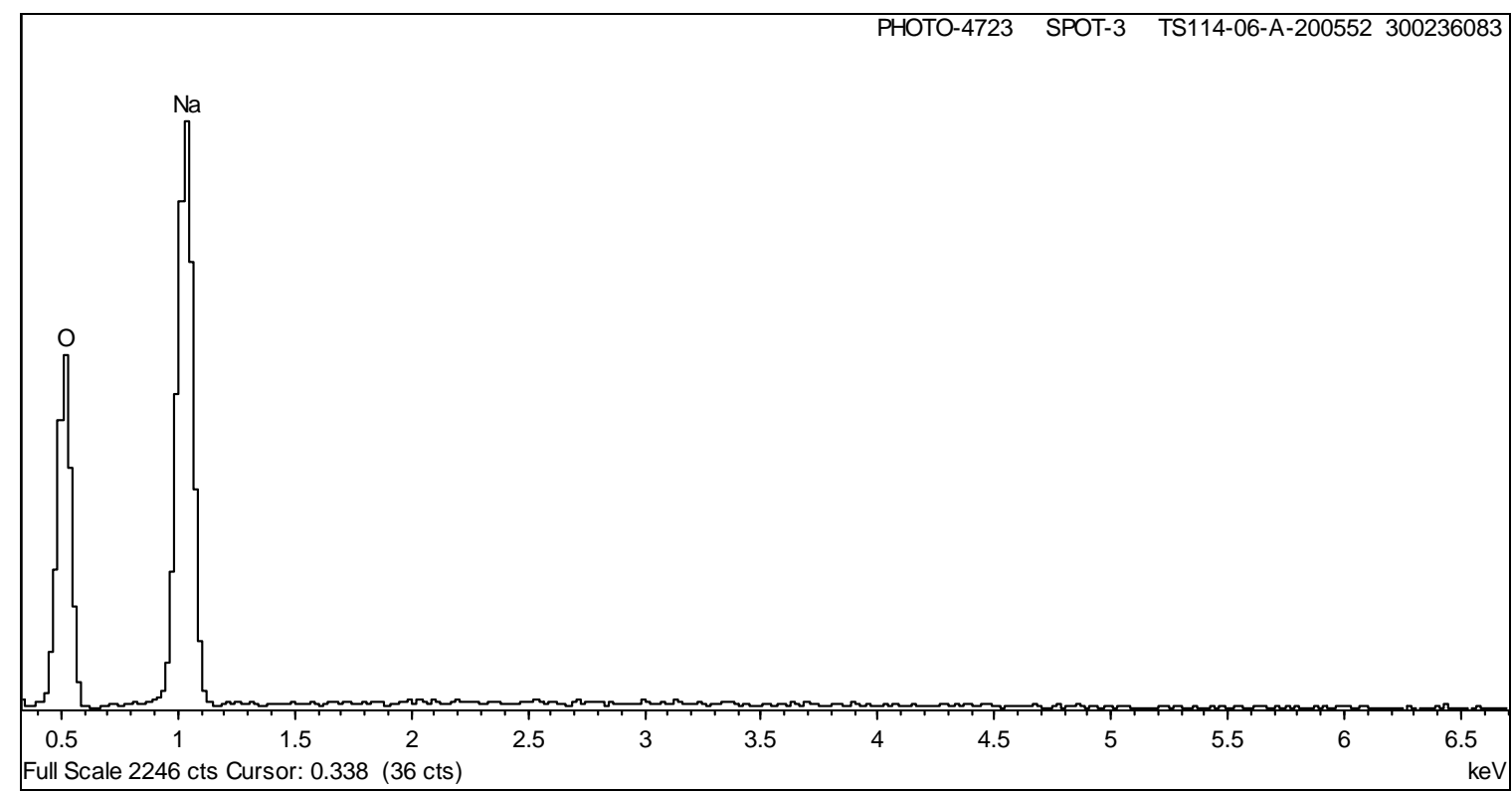

Figure 3.53 Spectrum of Spot 3 from Figure 3.51 


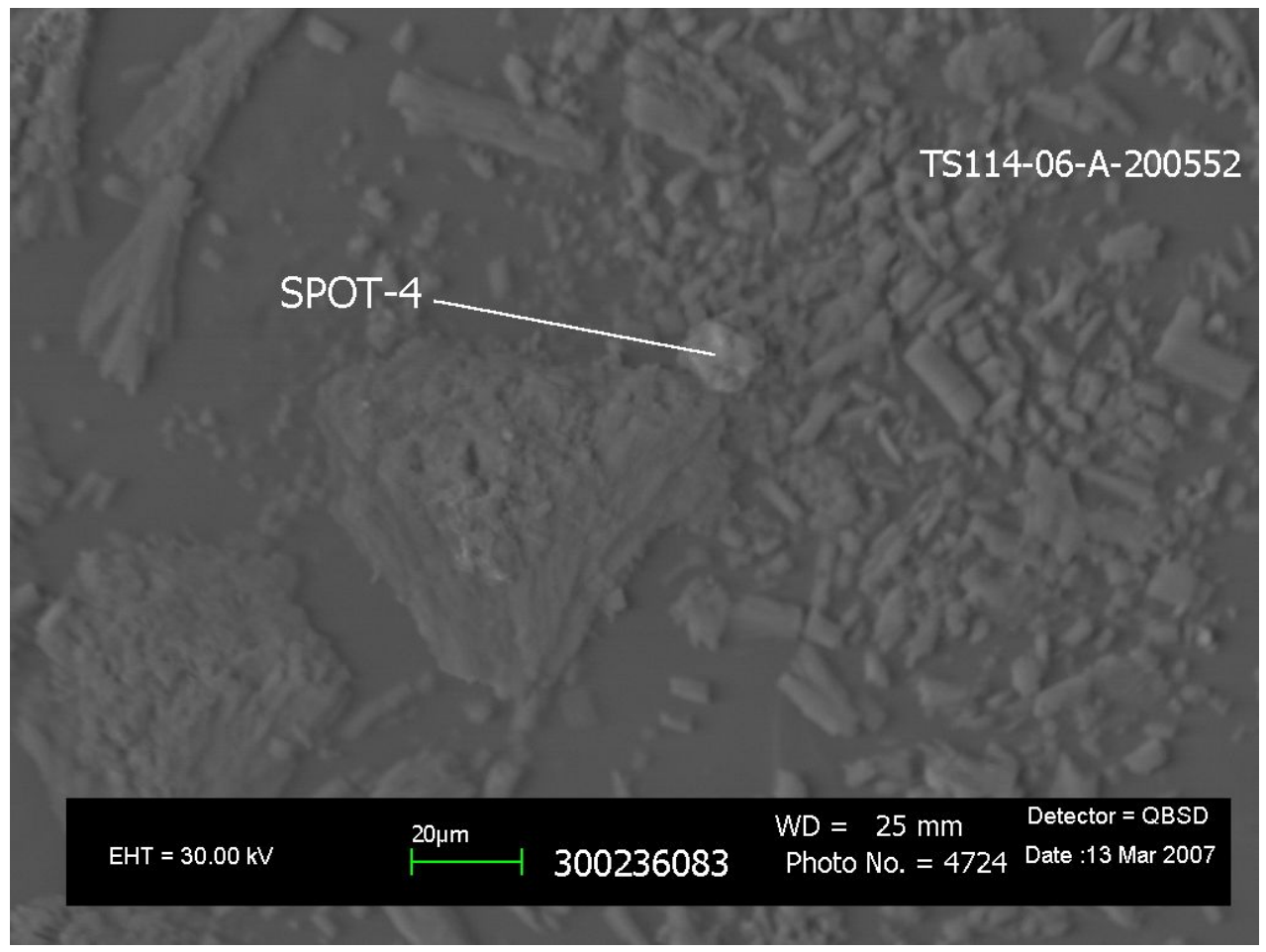

Figure 3.54 SEM Micrograph of Solids from $50^{\circ} \mathrm{C}$ Neutralization Test (500X Magnification)

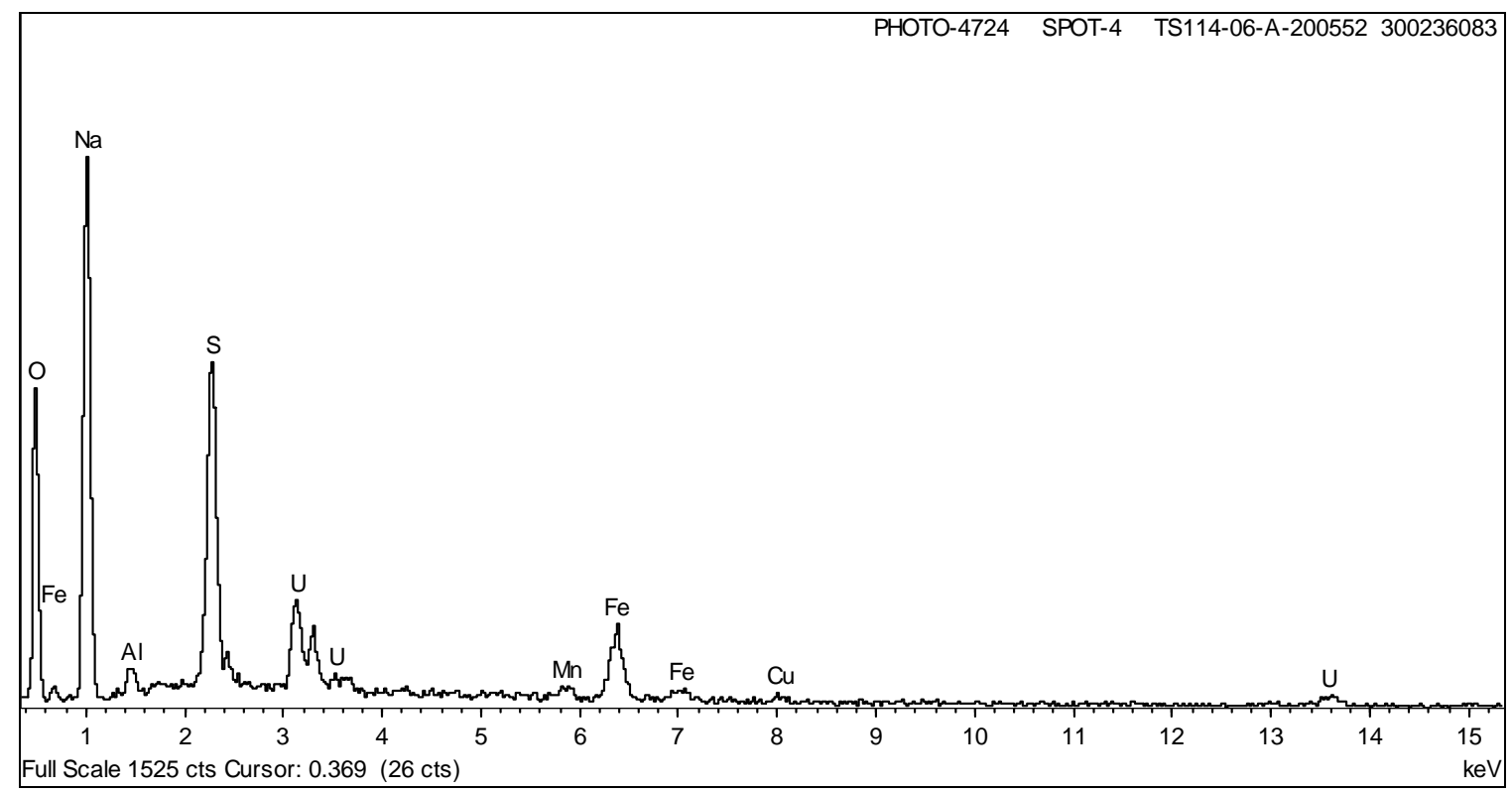

Figure 3.55 Spectrum of Spot 4 from Figure 3.54 


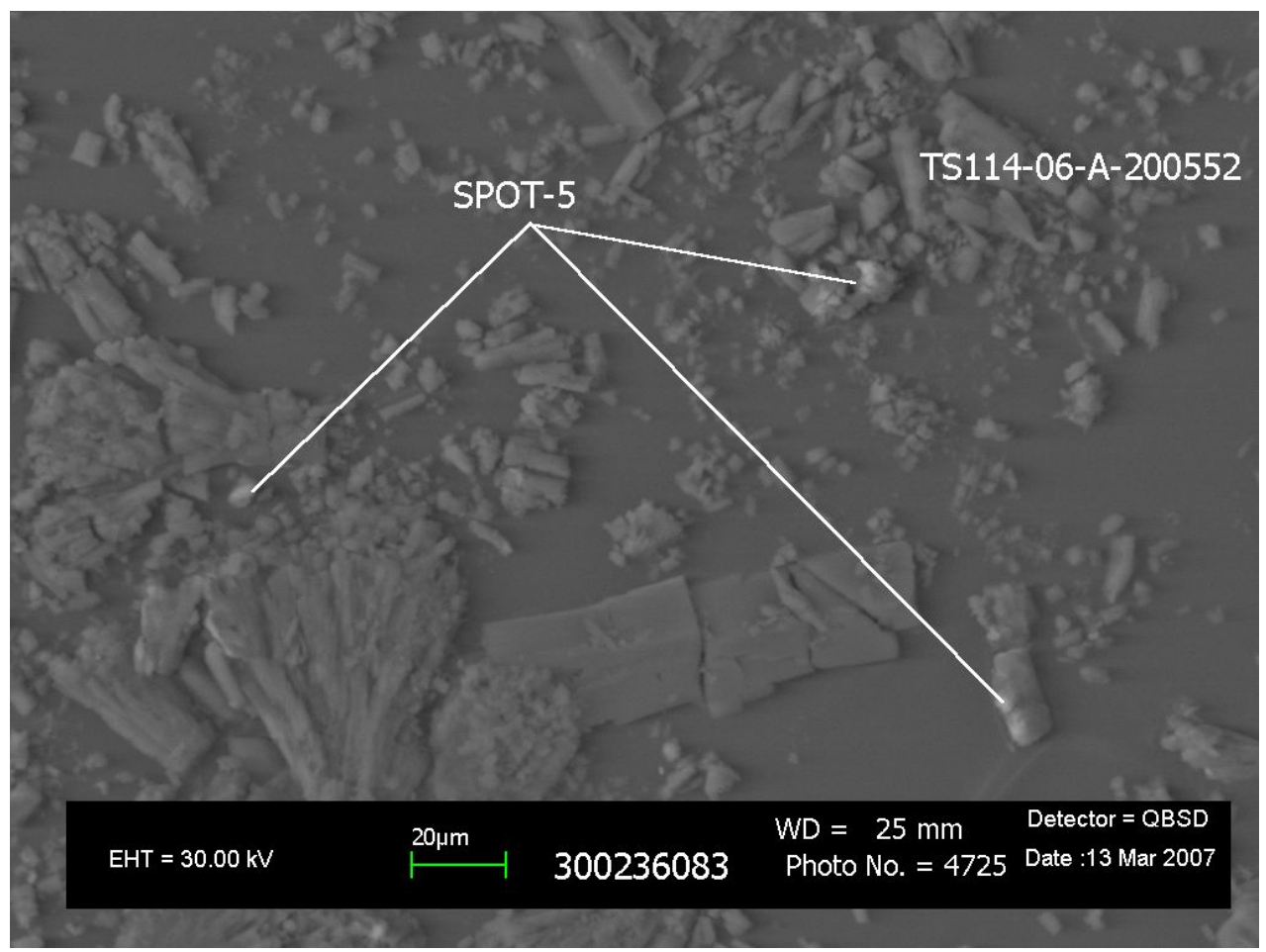

Figure 3.56 SEM Micrograph of Solids from $50^{\circ} \mathrm{C}$ Neutralization Test (431X Magnification)

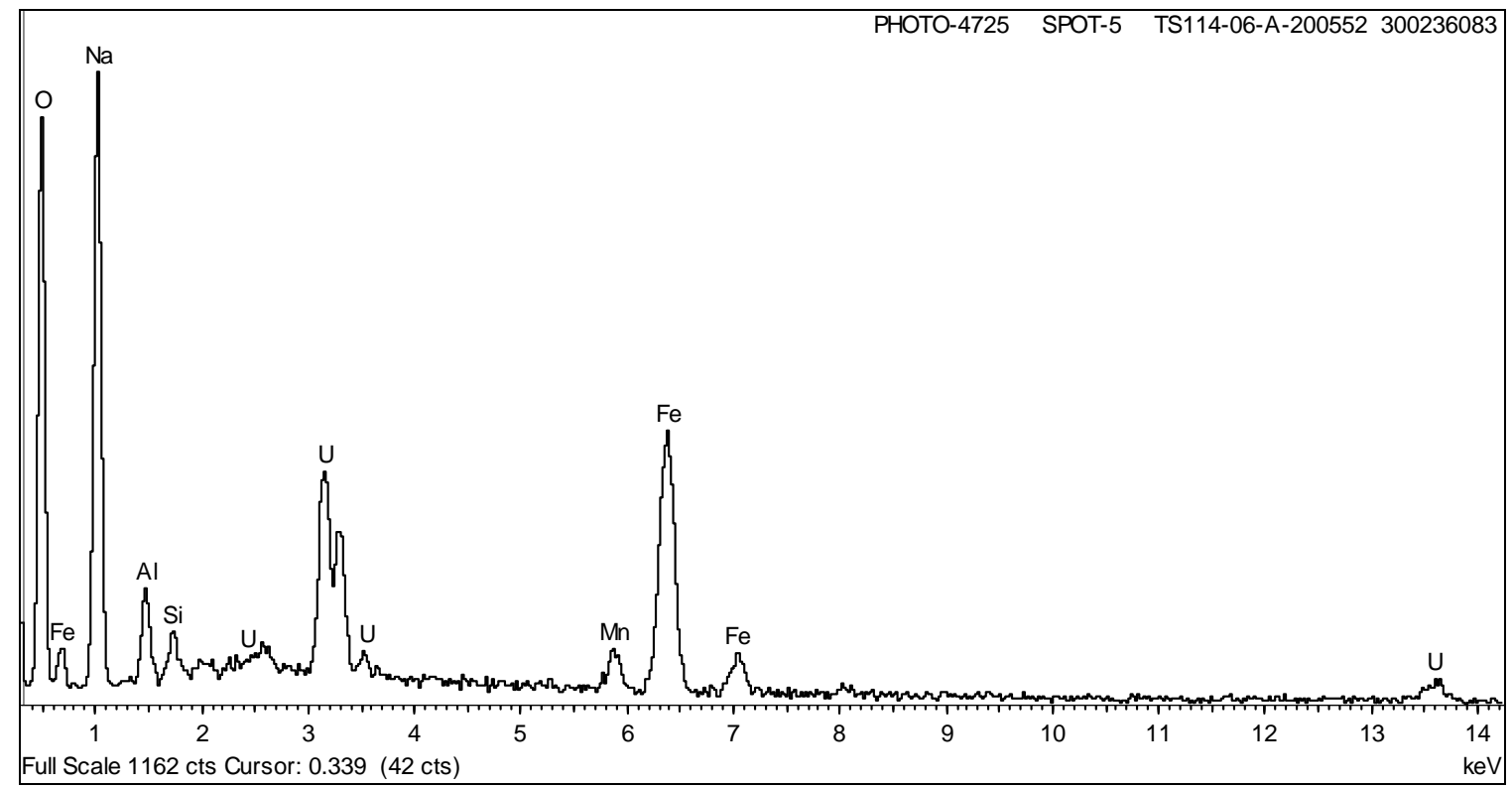

Figure 3.57 Spectrum of Spot 5 from Figure 3.56 


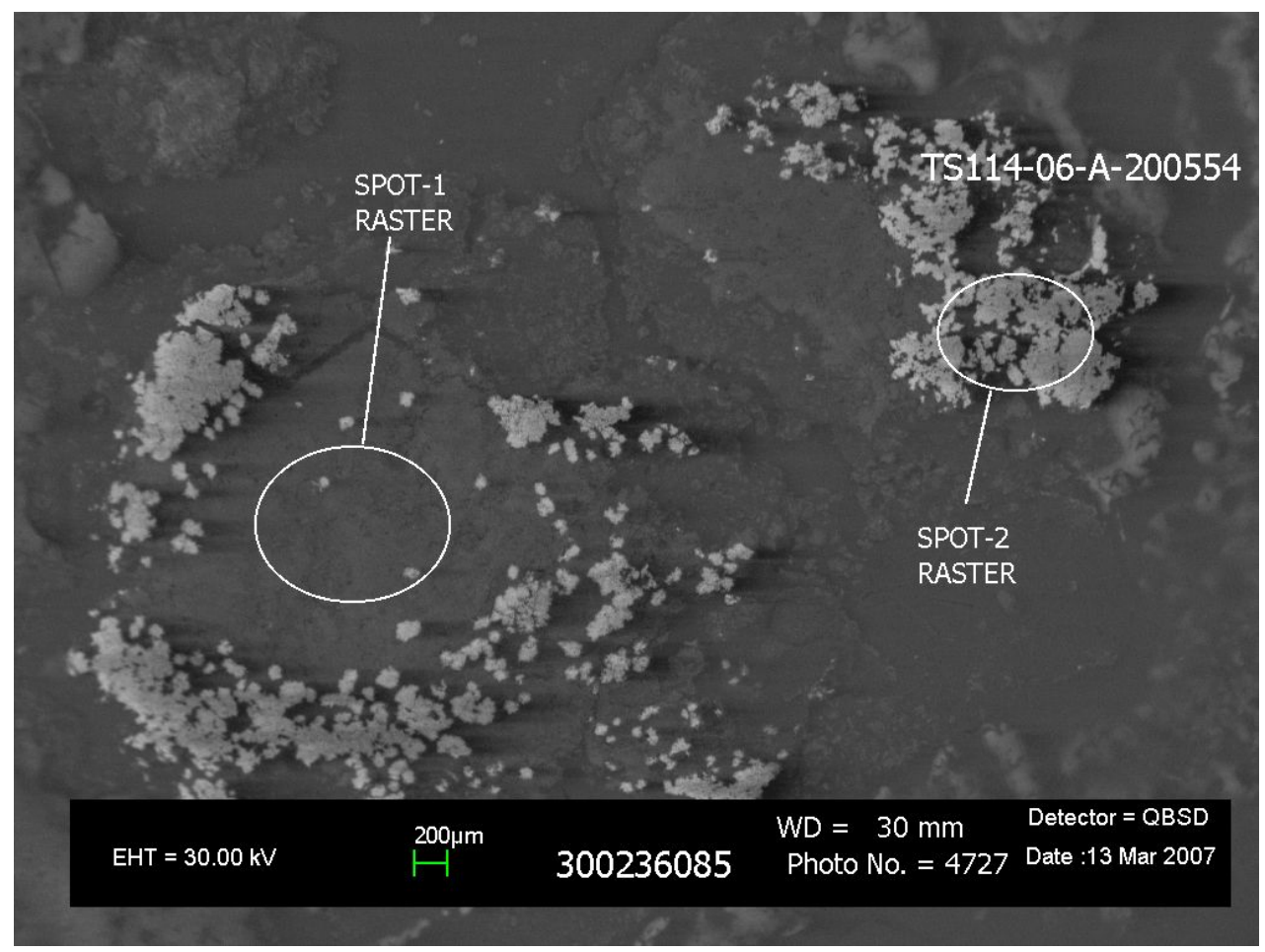

Figure 3.58 SEM Micrograph of Solids from $75^{\circ} \mathrm{C}$ Neutralization Test (15X Magnification)

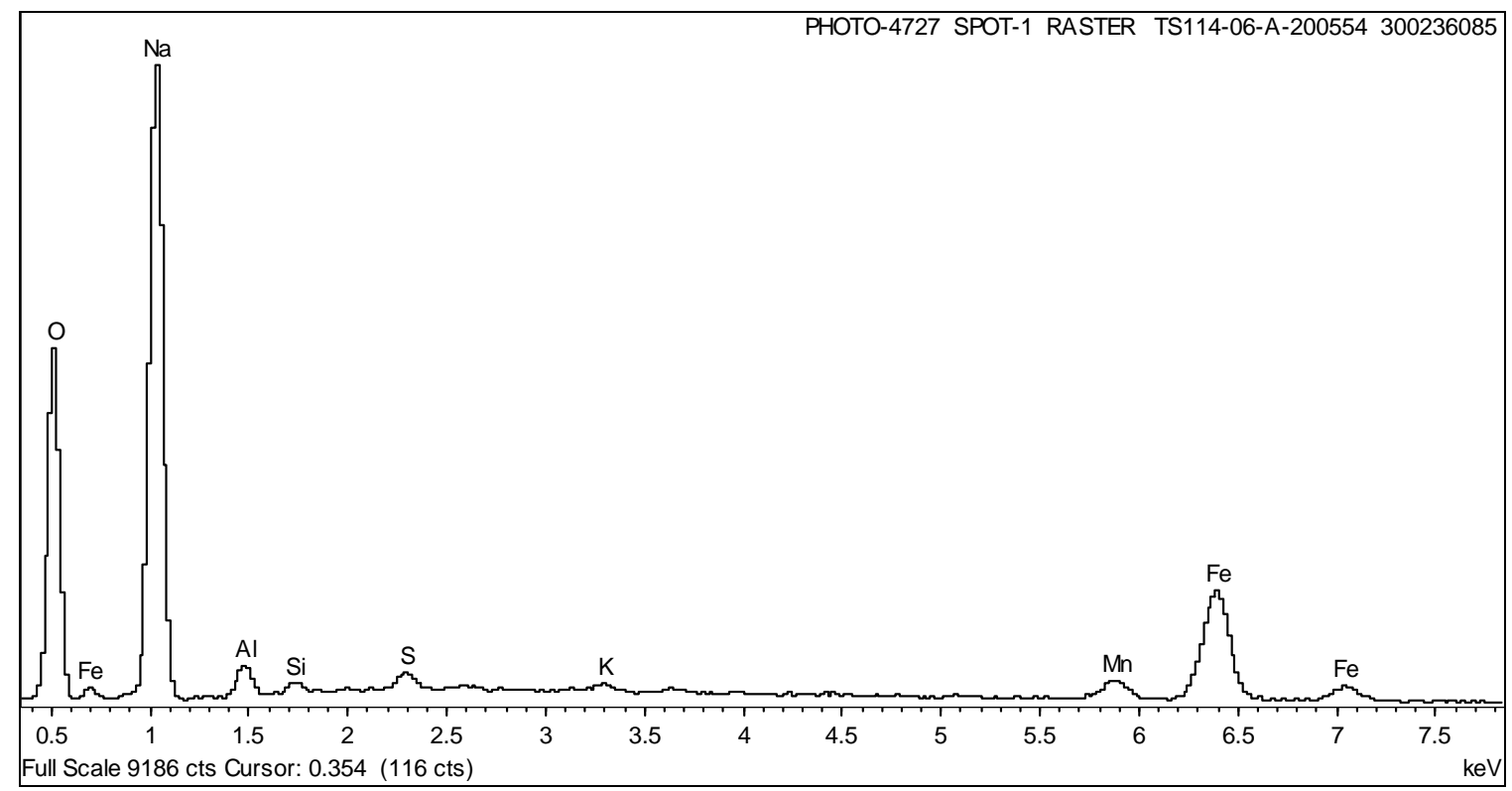

Figure 3.59 Spectrum of Spot 1 from Figure 3.58 


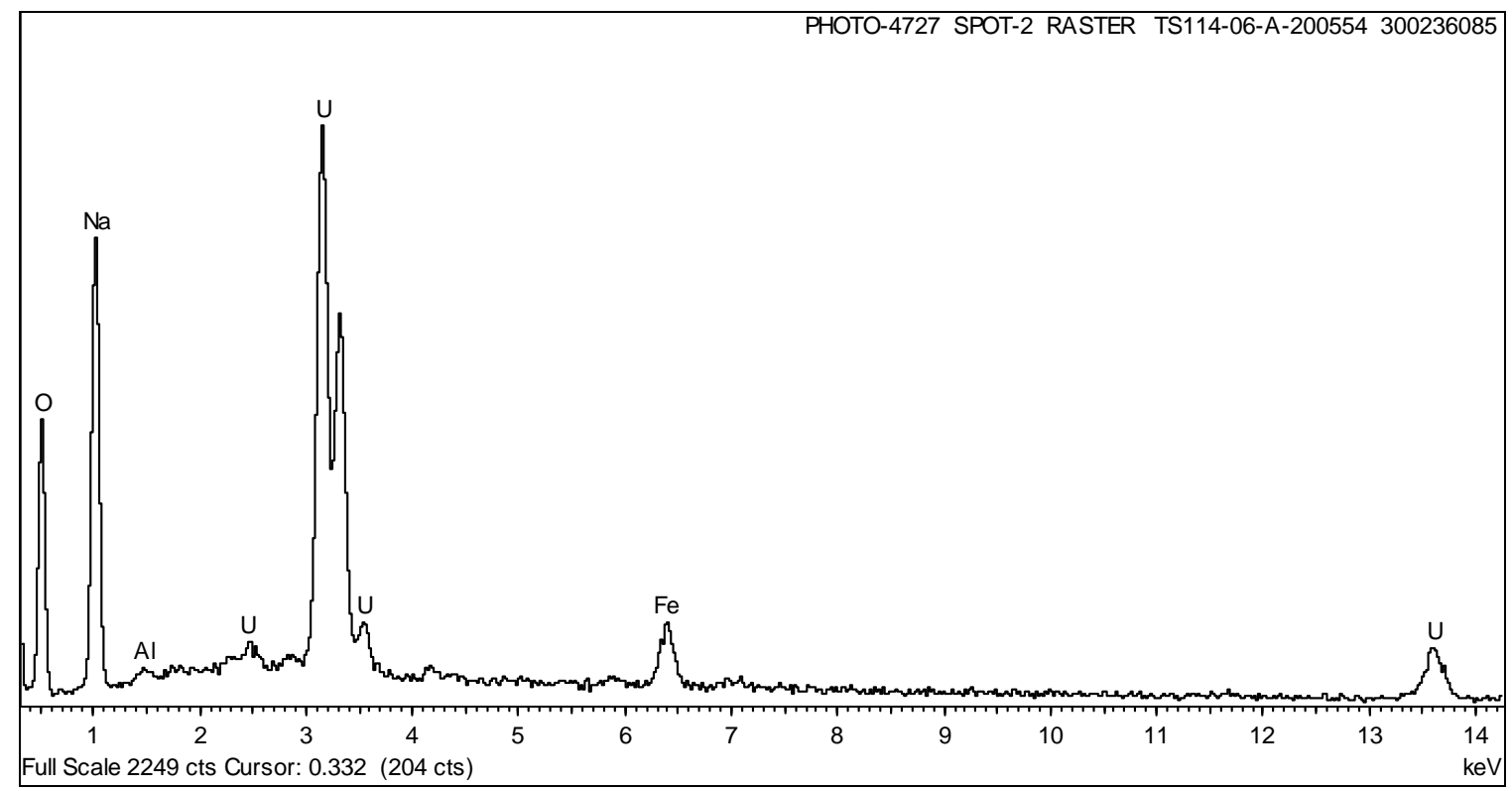

Figure 3.60 Spectrum of Spot 2 from Figure 3.58

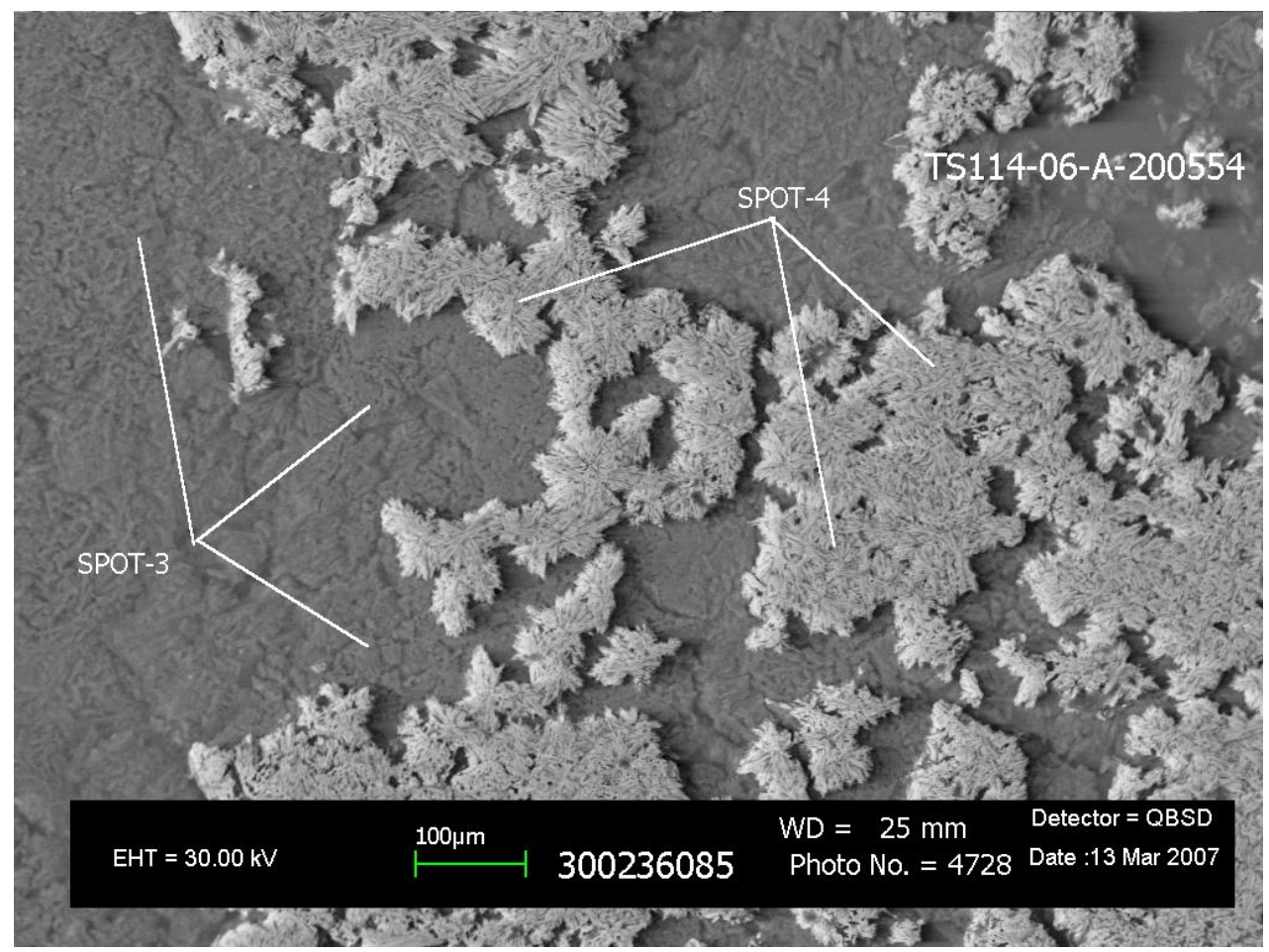

Figure 3.61 SEM Micrograph of Solids from $75^{\circ} \mathrm{C}$ Neutralization Test (100X Magnification) 


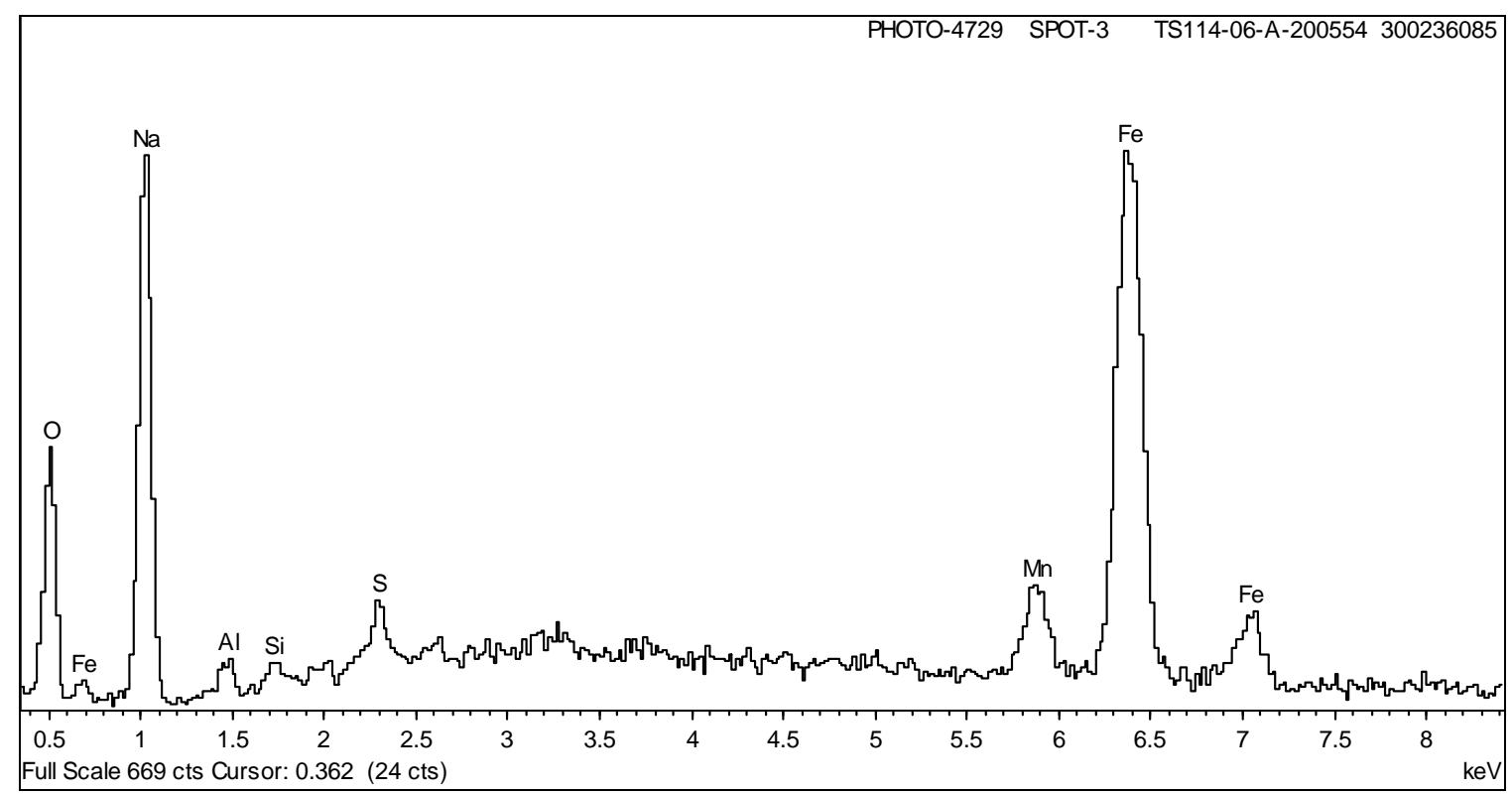

Figure 3.62 Spectrum of Spot 3 from Figure 3.61

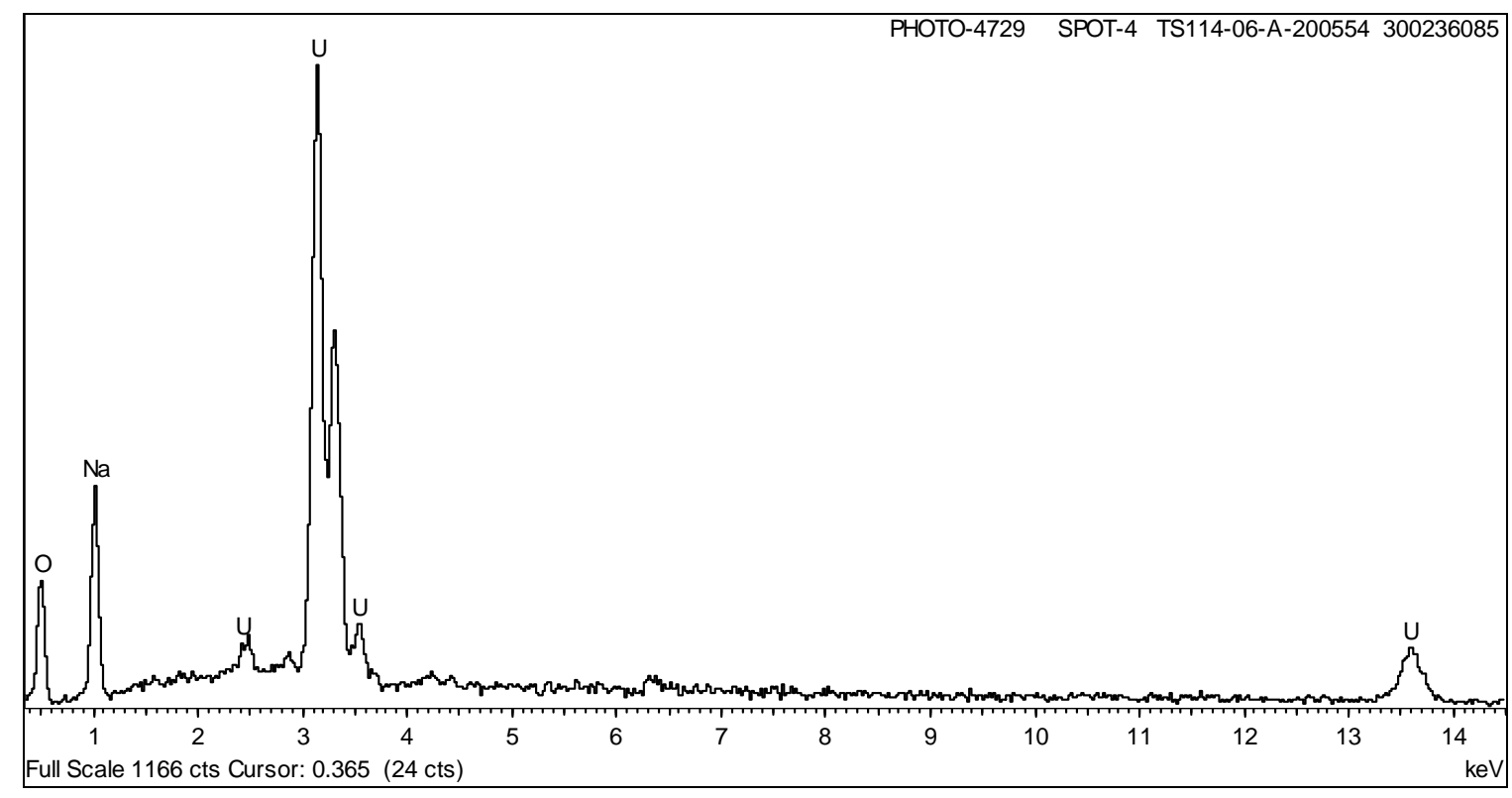

Figure 3.63 Spectrum of Spot 4 from Figure 3.61 
WSRC-STI-2007-00192, REV. 1

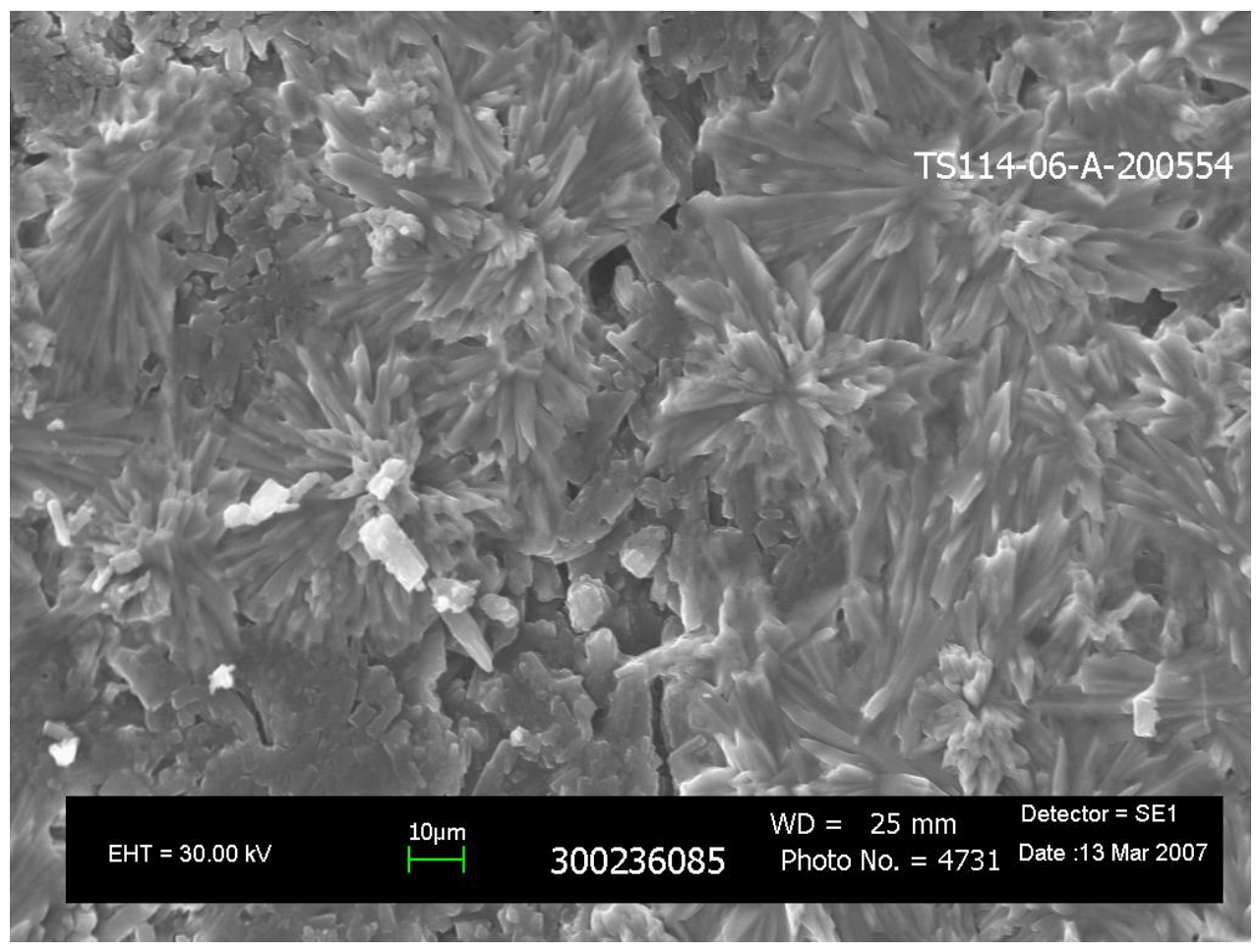

Figure 3.64 SEM Micrograph of Solids from $75^{\circ} \mathrm{C}$ Neutralization Test (500X Magnification) 


\subsection{DISCUSSION OF RESULTS}

\subsection{TANK 5F SLUDGE SAMPLE CHARACTERIZATION}

The characterization results for the Tank 5F sludge sample (FTF-05-06-55) appear quite good with respect to the tight precision of the sample replicates, good results for the glass standards, and minimal contamination found in the blanks and glass standards. The aqua regia and sodium peroxide fusion data also show good agreement between the two dissolution methods. Table 4-1 summarizes the composition of the key components of the sludge sample using the data from Tables 3.3 and 3.4.

Table 4-1. Summary of Tank 5F Sludge Composition

\begin{tabular}{|c|c|c|c|}
\hline Analyte & Average & \%RSD & $\begin{array}{c}\text { No. of Values } \\
\text { Averaged } \\
\end{array}$ \\
\hline $\mathrm{Fe} \mathrm{mg} / \mathrm{kg}$ & $3.73 E+05$ & $5.1 \%$ & 6 \\
\hline $\mathrm{U} \mathrm{mg} / \mathrm{kg}$ & $1.00 \mathrm{E}+05$ & $8.2 \%$ & $12^{\mathrm{a}}$ \\
\hline Mn mg/kg & $6.84 \mathrm{E}+04$ & $3.3 \%$ & 6 \\
\hline $\mathrm{Ni} \mathrm{mg} / \mathrm{kg}$ & $4.45 E+04$ & $8.2 \%$ & 6 \\
\hline $\mathrm{Na} \mathrm{mg} / \mathrm{kg}$ & $4.26 \mathrm{E}+04$ & $7.0 \%$ & $3^{c}$ \\
\hline Al mg/kg & $1.44 \mathrm{E}+04$ & $22 \%$ & 6 \\
\hline Si mg/kg & $1.18 \mathrm{E}+04$ & $4.2 \%$ & $3^{d}$ \\
\hline${ }^{233} \mathrm{U} \mathrm{mg} / \mathrm{kg}$ & $<1.0 \mathrm{E}+00$ & - & $3^{b}$ \\
\hline${ }^{234} \mathrm{U} \mathrm{mg} / \mathrm{kg}$ & $7.51 \mathrm{E}+00$ & $8 \%$ & $3^{b}$ \\
\hline${ }^{235} \mathrm{U} \mathrm{mg} / \mathrm{kg}$ & $5.98 \mathrm{E}+02$ & $4.7 \%$ & $6^{\mathrm{b}}$ \\
\hline${ }^{236} \mathrm{U} \mathrm{mg} / \mathrm{kg}$ & $3.65 \mathrm{E}+01$ & $12 \%$ & $6^{\mathrm{b}}$ \\
\hline${ }^{238} \mathrm{U} \mathrm{mg} / \mathrm{kg}$ & $9.55 E+04$ & $8.3 \%$ & $6^{\mathrm{b}}$ \\
\hline${ }^{137} \mathrm{Cs} \mathrm{mCi} / \mathrm{kg}$ & $1.09 \mathrm{E}+03$ & $1.5 \%$ & $3^{c}$ \\
\hline${ }^{90} \mathrm{Sr} \mathrm{mCi} / \mathrm{kg}$ & $3.70 \mathrm{E}+04$ & $17 \%$ & $3^{c}$ \\
\hline${ }^{99} \mathrm{Tc} \quad \mathrm{mCi} / \mathrm{kg}$ & 1.31E-02 & $4.7 \%$ & $3^{d}$ \\
\hline${ }^{237} \mathrm{~Np} \mathrm{mCi} / \mathrm{kg}$ & $<4.4 \mathrm{E}-02$ & - & $3^{d}$ \\
\hline${ }^{238} \mathrm{Pu} \quad \mathrm{mCi} / \mathrm{kg}$ & $1.95 \mathrm{E}+00$ & $12 \%$ & 6 \\
\hline${ }^{239 / 240} \mathrm{Pu} \quad \mathrm{mCi} / \mathrm{kg}$ & $8.48 E+00$ & $5.8 \%$ & 6 \\
\hline${ }^{241} \mathrm{Pu} \quad \mathrm{mCi} / \mathrm{kg}$ & $8.05 E+00$ & $7.6 \%$ & 6 \\
\hline
\end{tabular}

Divide $\mathrm{mg} / \mathrm{kg}$ values by $1 \mathrm{E}+04$ to convert to $\mathrm{wt} \%$ dried solids basis

a Total uranium from averaging the combined values from ICP-ES and ICP-MS methods.

b Uranium isotopics obtained from averaging only ICP-MS. The sum of the uranium isotopes does not exactly match the total uranium since only a subset of the values could be used for the isotopics.

c Data taken from the aqua regia dissolution

d Data taken from the sodium peroxide fusion dissolution 
The CSEM analysis indicates a material composed of fine particles with larger pieces builtup from the fine particles. The elemental compositions of the EDX spectra of selected spots on the micrographs generally agree with chemical composition in Table 4-1. Some spectra appear to indicate areas of elevated uranium concentration within the sludge.

\subsection{TANK 5F SALT SAMPLE CHARACTERIZATION}

The XRD and CSEM results for the Super Snapper salt sample from Tank 5F (FTF-05-07-1) indicate the material contains hydrated sodium carbonate and bicarbonate salts along with some aluminum hydroxide. These compounds likely precipitated from the supernate in the tank. A solubility test showed the material to be water-soluble consistent with the determined composition.

\subsection{SLUDGE DISSOLUTION IN THE SIMULATED OXALIC ACID CLEANING TESTS}

The analytical data for the solid residues filtered from the oxalic acid solution and filtered oxalic acid indicate a large portion of the Tank 5F sludge used in the tank cleaning test dissolved into the oxalic acid. The results of a material balance calculation, shown in Table 4-2, provide an estimate of the percentage of the major elements in the sludge that dissolved into the acid. The calculation used the known weight and composition of Tank 5F sludge used in the test, the concentrations measured in the filtered oxalic acid, and the known volume of oxalic acid used to estimate the percentage of each element dissolved from the sludge. The estimated percentage of iron dissolved from the sludge may be slightly high since some of the iron in the filtered oxalic acid solution could result from dissolution of the carbon steel coupon. The calculation used the solution compositions in the filtered oxalic acid because a material balance calculation based on the weight of solids used in the test and the weight of solids recovered could lead to erroneous conclusions due to the precipitation of oxalates observed in the test. Additionally, the small scale of the test made quantitative recovery of the solids difficult.

The results presented in Table 4-2 indicate a high percentage of the iron, uranium, sodium, and aluminum dissolved during both tests. Approximately half of the manganese, a small portion of the plutonium, and essentially none of the nickel dissolved during the tank cleaning tests. Additionally, the results show slightly higher dissolution of the sludge in the $75{ }^{\circ} \mathrm{C}$ test compared to the $50{ }^{\circ} \mathrm{C}$ test however, the amount of sludge dissolution gained by using the higher temperature remains small. Percentages of ${ }^{99} \mathrm{Tc}$ and ${ }^{237} \mathrm{~Np}$ removed during the test could not be calculated since all of the samples analyzed, with the exception of the initial Tank 5F sludge, contained less than detectable quantities. 
Table 4-2. Estimated Percentage of Key Elements Dissolved from the Tank 5F Sludge during Tank Cleaning Tests based on Oxalic Acid Analysis

\begin{tabular}{|l|c|c|}
\hline Analyte & $\begin{array}{c}\text { Percentage } \\
\text { Dissolved in } \\
\mathbf{5 0}^{\circ} \mathbf{C} \text { Test }\end{array}$ & $\begin{array}{c}\text { Percentage } \\
\text { Dissolved in } \\
\mathbf{7 5}^{\circ} \mathbf{C} \text { Test }\end{array}$ \\
\hline $\mathrm{Fe}$ & 62 & 76 \\
\hline $\mathrm{U}$ & 73 & 87 \\
\hline $\mathrm{Mn}$ & 40 & 59 \\
\hline $\mathrm{Ni}$ & 0.1 & 0.1 \\
\hline $\mathrm{Na}$ & 96 & 95 \\
\hline $\mathrm{Al}$ & 84 & 107 \\
\hline${ }^{238} \mathrm{Pu}$ & 2.9 & 2.9 \\
\hline${ }^{239 / 240} \mathrm{Pu}$ & 3.2 & 2.9 \\
\hline
\end{tabular}

Since no nickel was detected in the oxalic acid filtrate from the tank cleaning tests, all of the nickel originally present in the small amount of Tank 5F sludge used for the test should still be present in the reduced amount of sludge solids remaining at the end of the test. This allows the possibility of using the results from the analysis of the solids filtered from the oxalic acid to calculate a material balance avoiding the complicating factor of the oxalates observed to precipitate during the test. Normalizing the resulting compositions of the solids filtered from the oxalic acid solutions to nickel removes the contribution of oxalates or other solids that precipitated during the tests. Table 4-3 shows the estimated percentage of key elements from the sludge dissolved during the test based on the analytical results of the solids.

Table 4-3. Estimated Percentage of Key Elements Dissolved from the Tank 5F Sludge during Tank Cleaning Tests based on the Solids Analysis

\begin{tabular}{|l|c|c|c|c|c|}
\hline Analyte & $\begin{array}{c}\text { Tank 5F Sludge } \\
\text { Normalized to } \\
\text { Nickel }\end{array}$ & $\begin{array}{c}\mathbf{5 0}^{\circ} \mathbf{C} \text { Solids } \\
\text { Normalized to } \\
\text { Nickel }\end{array}$ & $\begin{array}{c}\mathbf{7 5}^{\circ} \mathbf{C} \text { Solids } \\
\text { Normalized to } \\
\text { Nickel }\end{array}$ & $\begin{array}{c}\text { Percentage } \\
\text { Dissolved in } \\
\mathbf{5 0}{ }^{\circ} \mathbf{C} \text { Test }\end{array}$ & $\begin{array}{c}\text { Percentage } \\
\text { Dissolved in } \\
\mathbf{7 5}^{\circ} \mathbf{C} \text { Test }\end{array}$ \\
\hline $\mathrm{Fe}$ & 8.38 & 3.40 & 0.36 & 59 & 96 \\
\hline $\mathrm{U}$ & 2.36 & 0.06 & 0.01 & 98 & 99 \\
\hline $\mathrm{Mn}$ & 1.54 & 0.85 & 0.44 & 45 & 71 \\
\hline $\mathrm{Ni}$ & 1.00 & 1.00 & 1.00 & 0 & 0 \\
\hline $\mathrm{Na}$ & 0.96 & 0.06 & 0.03 & 93 & 97 \\
\hline $\mathrm{Al}$ & 0.32 & 0.03 & 0.01 & 91 & 97 \\
\hline $238 \mathrm{Pu}$ & $2.56 \mathrm{E}-06$ & $1.28 \mathrm{E}-06$ & $1.28 \mathrm{E}-06$ & 50 & 51 \\
\hline $239 / 240 \mathrm{Pu}$ & $3.11 \mathrm{E}-03$ & $1.49 \mathrm{E}-03$ & $1.49 \mathrm{E}-03$ & 52 & 52 \\
\hline
\end{tabular}


The estimated percentage of elements dissolved between the two methods of calculation show reasonable agreement for the major components of the sludge. However, the calculation based on the concentrations dissolved in the filtered oxalic acid should be more accurate due to the complicating factors mentioned previously for the calculations based on the solids analysis. The greatest disparity between the two data sets involves the amount of plutonium dissolved during the tank cleaning test. The calculation based on the concentrations dissolved in the filtered oxalic acid shows very little plutonium dissolved from the sludge while the calculation based on the solids analysis show approximately half of the plutonium dissolved. The reasons for this discrepancy remain unclear but it should be noted that the plutonium data from the filtered oxalic acid analysis of the $50{ }^{\circ} \mathrm{C}$ test show high \%RSD probably resulting from the very low concentrations present in solution. Additionally, recall that only a single sample replicate was analyzed for the solids from the $50{ }^{\circ} \mathrm{C}$ cleaning test. However, the data from the $50{ }^{\circ} \mathrm{C}$ test appear consistent with the results from the $75^{\circ} \mathrm{C}$ test that included triplicate analysis of the sample with blanks and glass standards.

\subsection{DISCUSSION OF RESULTS FROM NEUTRALIZATION OF THE OXALIC ACID FILTRATE}

The neutralization of the filtered oxalic acid solutions from the cleaning test produced a large volume of solids ( $\sim 2 \mathrm{X}$ the original sludge mass after filtration and air drying). A large portion of the increase in solids could be attributed to the formation of sodium oxalate. The data from analysis of the solid residues filtered from the neutralization tests and the filtrate obtained indicate most of the iron, uranium, manganese, and a large portion of the aluminum precipitated during the neutralization tests. The data for the $50{ }^{\circ} \mathrm{C}$ test and the $75{ }^{\circ} \mathrm{C}$ test show good agreement with the exception of the amount of aluminum precipitated from the neutralization. The $75^{\circ} \mathrm{C}$ test data indicates much less aluminum precipitated during that test. The data from the analysis of the neutralization test filtrate corroborates the solid residue data.

The slower addition rate of the oxalic acid filtrate to the simulated Tank 7F supernate in the $75{ }^{\circ} \mathrm{C}$ test might account for the differing amounts of aluminum precipitated. In the $50{ }^{\circ} \mathrm{C}$ test the oxalic acid filtrate was added subsurface via syringe to the simulated supernate over the course of a few minutes. This high rate of addition caused the entire solution to become cloudy with precipitated solids immediately throughout the vessel. The $75^{\circ} \mathrm{C}$ neutralization test used a specially modified peristaltic pump to add the oxalic acid filtrate at a slow enough rate (approximately 1 hour for the addition) so that very little mixing occurred in the vessel during the addition. Solids formed at the exit of the subsurface addition tube and several layers formed as a result of the slow addition rate. The $\mathrm{pH}$ change in the vessel as a whole was much slower during and immediately after addition as compared to the $50{ }^{\circ} \mathrm{C}$ test. However, after several hours the vessel for the $75^{\circ} \mathrm{C}$ test was fully mixed to observe whether the layers were easily dispersed. The mixing rapidly neutralized any remaining acidic layers (low $\mathrm{pH}$ ) and all of the precipitated solids slowly settled to the bottom of the vessel. The rate of $\mathrm{pH}$ change in the test vessel during neutralization could reasonably be expected to impact the particle size/morphology and the composition of the precipitates formed. 
The CSEM data for the two neutralization tests indicate differences in the particle size/morphology and composition of the particulates. The CSEM data from the $50{ }^{\circ} \mathrm{C}$ test show larger particles of distinct shape and some large particles that appear to be an aluminum hydroxide phase indicative of separation of aluminum from other typical sludge elements. The CSEM data from the $75^{\circ} \mathrm{C}$ test shows a much finer crystalline structure with no areas indicative of aluminum separation. Some evidence of uranium separation from other sludge elements appears in the $75^{\circ} \mathrm{C}$ data, however, areas of high uranium content were also found in the sludge sample.

\subsection{DISCUSSION OF THE FATE OF PLUTONIUM AND URANIUM IN THE SIMULATED TANK CLEANING TESTS}

The data collected from the tank cleaning and neutralization tests indicates most of the uranium dissolved during the cleaning test with oxalic acid along with the iron, aluminum, and sodium in the sludge. The analysis of the oxalic acid filtrates indicates that only a small portion of the plutonium dissolved during the cleaning test. However, the analytical data from the solid residues filtered from the cleaning test contradict the solution data and indicate approximately half of the plutonium dissolved. The low concentration of plutonium in the test samples complicates the determination of fate of plutonium in the cleaning tests. Additional testing may be required to conclusively determine the fate of plutonium during tank cleaning with oxalic acid.

During the neutralization of the oxalic acid, the majority of the uranium precipitates from solution along with the iron and other typical sludge elements. The CSEM results of the $75^{\circ} \mathrm{C}$ neutralization test provide some evidence of uranium separation from other sludge elements. However, the CSEM analysis looked at a very small amount of sample, which might not be representative of the bulk material and the sludge sample also showed areas of high uranium concentration. Additionally, how the test results will scale to the full-scale waste tank remains uncertain. The neutralization tests did not investigate plutonium distribution in the post test samples.

The uncertainty in the fate of plutonium and uranium in these tests should be weighed against the small amount of material remaining in Tank 5F. Chemical cleaning and additional mechanical sluicing planned for the tank will further reduce the inventory. From a regulatory perspective, additional samples of the material remaining after cleaning and heel removal will be obtained to serve as the basis for compliance. 


\subsection{REFERENCES}

1. T. M. Punch, Technical Task Request: Tank 5 Sample Analysis, HLE-TTR-2006-009, December 4, 2006.

2. D.T. Herman, B. J. Wiersma, F. F. Fondeur, J. C. Wittkop, J. M. Pareizs, K. P. Crapse, M. S. Hay, M. R. Poirier, S. D. Fink, Investigating Hydrogen Generation and Corrosion in the Treatment Tank and the Potential Formation of a Floating Layer in Neutralization Tank During High Level Waste Tank Heel Chemical Cleaning, WSRC-STI-2007-00209, Rev. 0, April 30, 2007.

3. M. S. Hay, Task Technical and Quality Assurance Plan for Characterization of Samples from Tank 5F, WSRC-RP-2006-00717, Rev. 0, August 30, 2006.

4. M. S. Hay, Analytical Study Plan for the Characterization of Tank 5F Samples, SRNL-CST-2006-00085, October 30, 2006.

5. C. J. Coleman, R. A. Dewberry, M. F. Bryant, J. J. Gemmill, SRL's Performance in Round Robin \#6 - Analysis of Simulated Defense Waste Glass (U), WSRC-TR-91187, Rev. 0, May 31, 1991.

6. $\quad$ E. W. Washburn, (1926 - 1930; 2003), International Critical Tables of Numerical Data, Physics, Chemistry and Technology (1st Electronic Edition), Vol. 5, page 21.

7. M. S. Hay, T. B. Edwards, Statistical Analysis of ESP Verification Test Samples, WSRC-RP-94-1224, November 4, 1994. 